Fall 1978

\title{
1978 Miracle Yearbook
}

\section{Cedarville College}

Follow this and additional works at: https://digitalcommons.cedarville.edu/yearbooks

Part of the Higher Education Commons, Organizational Communication Commons, and the Public Relations and Advertising Commons

\section{Recommended Citation}

Cedarville College, "1978 Miracle Yearbook" (1978). Yearbooks. 25.

https://digitalcommons.cedarville.edu/yearbooks/25

This Book is brought to you for free and open access by DigitalCommons@Cedarville, a service of the Centennial Library. It has been accepted for inclusion in Yearbooks by an authorized administrator of DigitalCommons@Cedarville. For more information, please contact digitalcommons@cedarville.edu. 

.

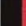

-

西

西

. 




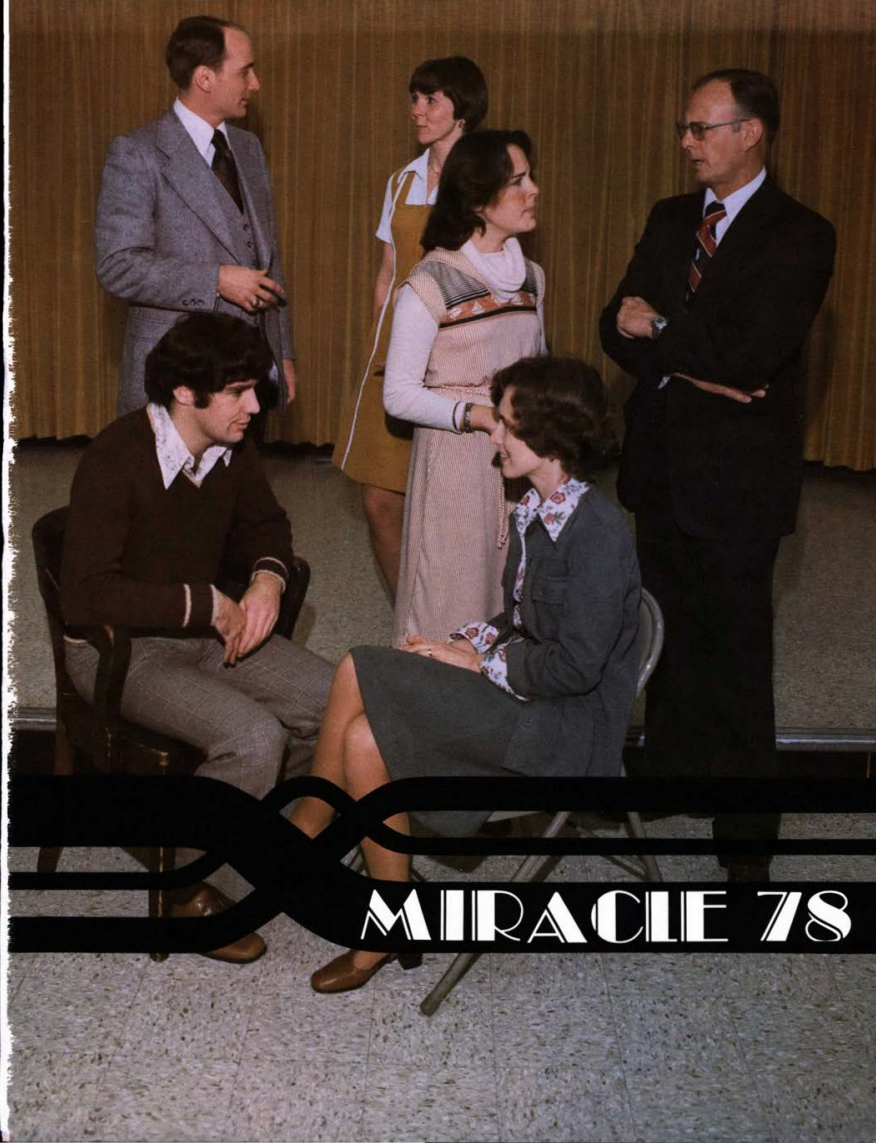




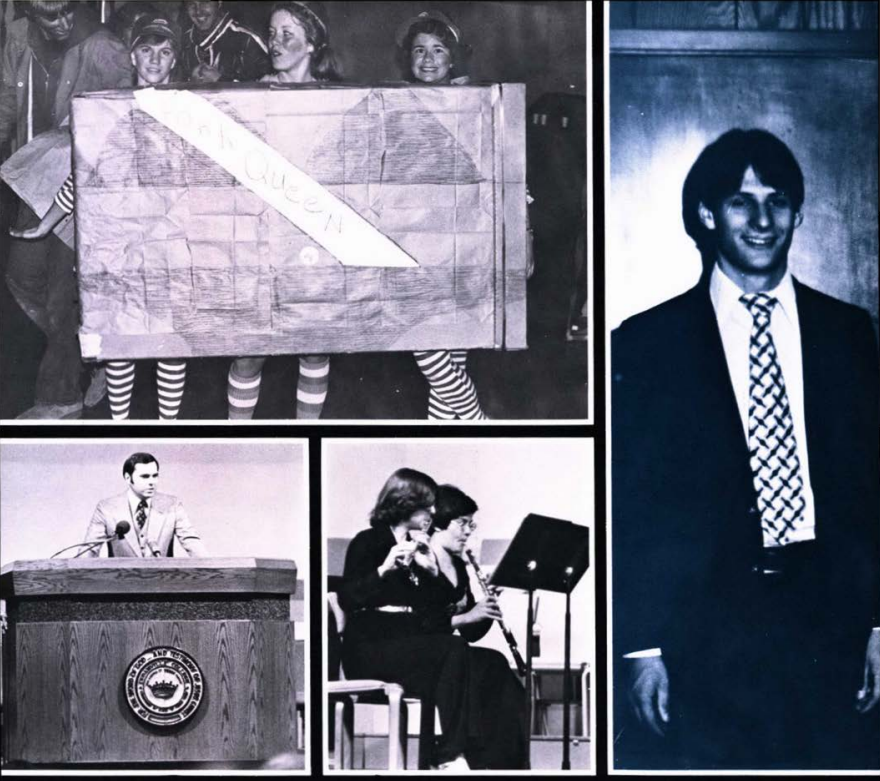




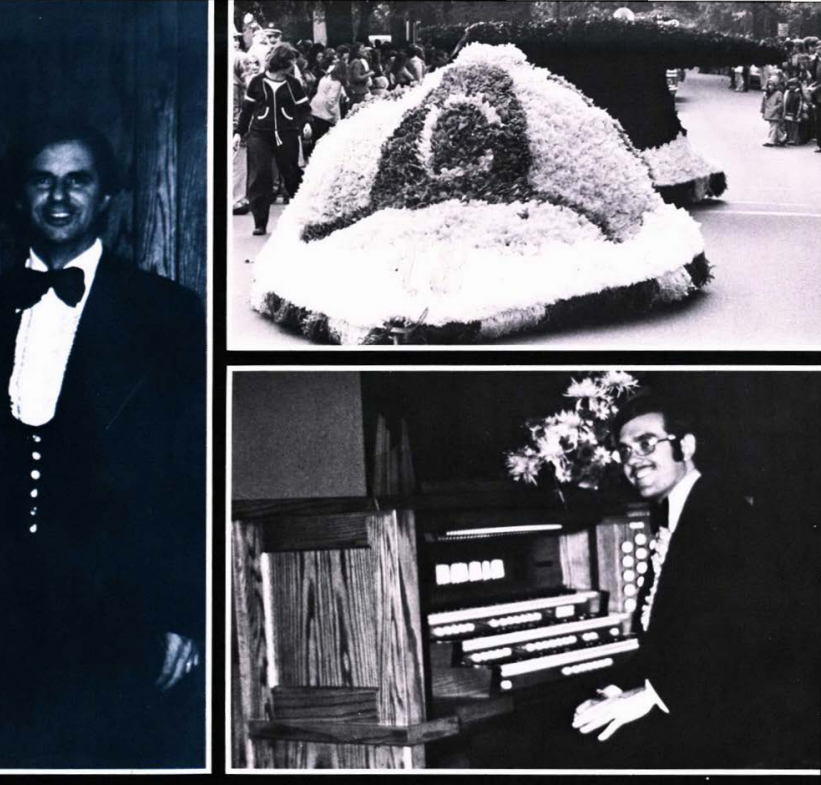

\section{SIDIECUAU $\|E V\| E N] S$}




\section{Orientation And Bible}

Conference Highlight College Week

Expectancy ... Fear. Excitement ... Every student is feeling something different when he walks on Cedarville's campus to commence the 77-78 school year. College Week is designed to prepare him for the upcoming nine months of spiritual and mental growth. Freshmen are especially busy during the week, arriving a few days earlier than upperclassmen to register and attend orientation sessions. All students attend daily meetings with Rev. Don Tyler and Rev. Galen Call, speakers for the week.

Challenges are made and invitations accepted to start the school year with God at the center of every life. Al Smith, a special highlight of the week. ministers through song. Sophomores host the Freshmen

to a game night at the week's end which proves to be fun for all

1. "Is this the shoe sale they advertised?"

2. Galen Call explains spiritual truths to a student.

\section{Opposite page}

1. "How many lunch hours are required for graduation?

2. Don Tyler listens intently to Al Smith as he tells another "fish" tale.
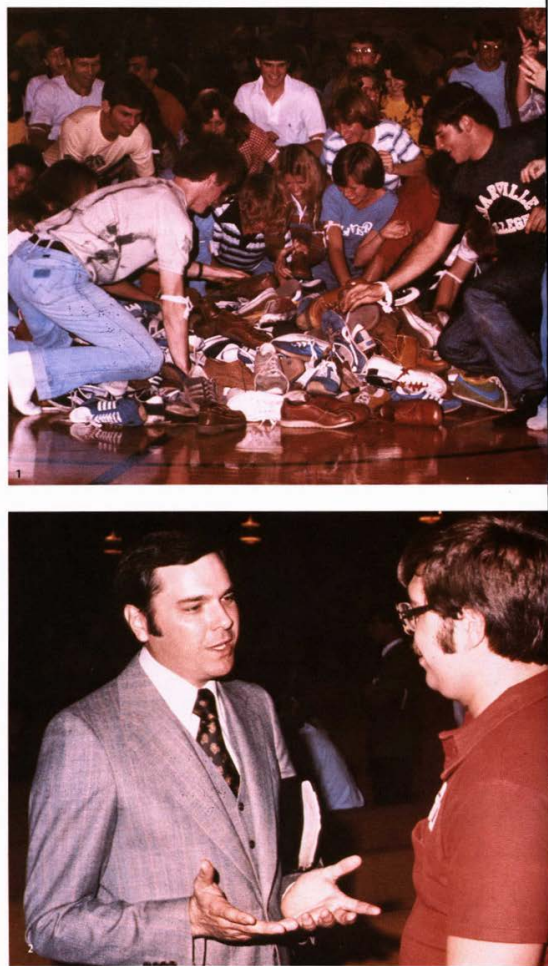


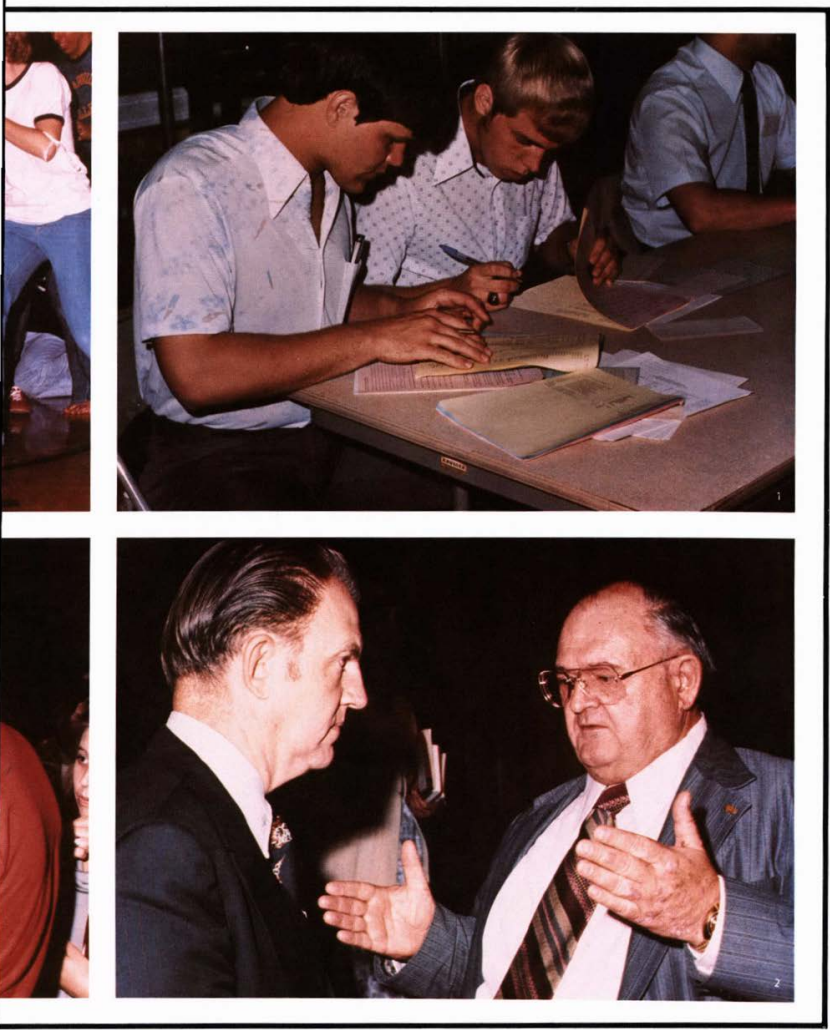




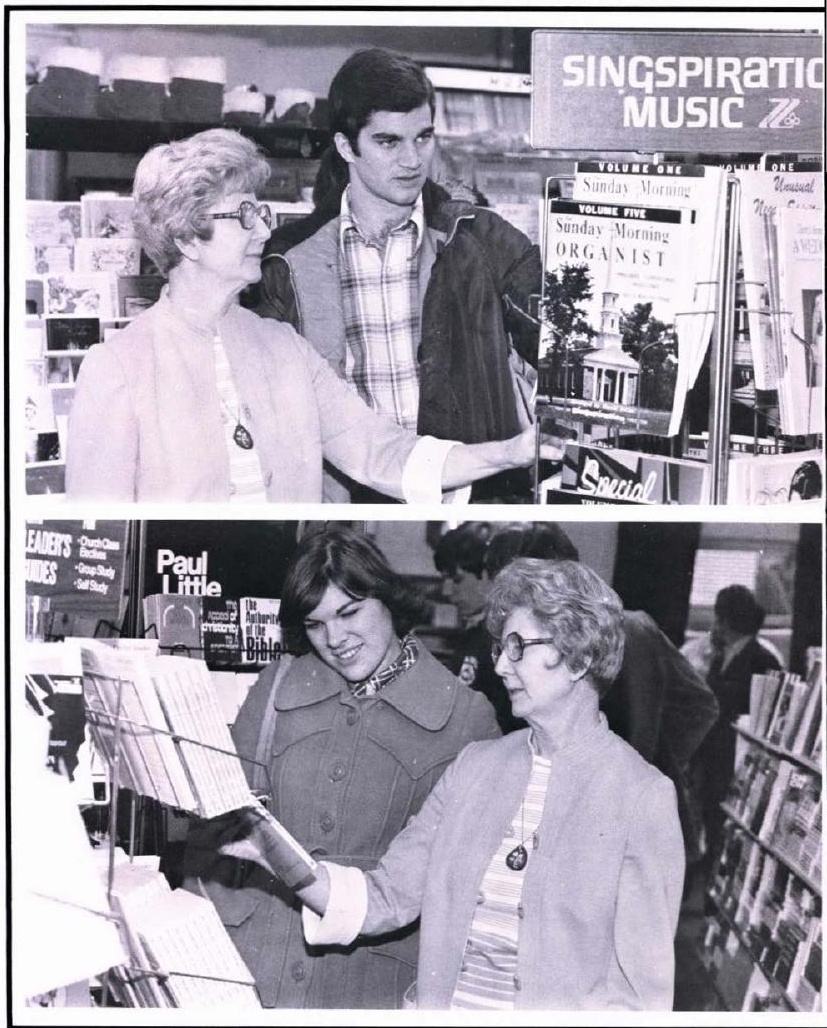




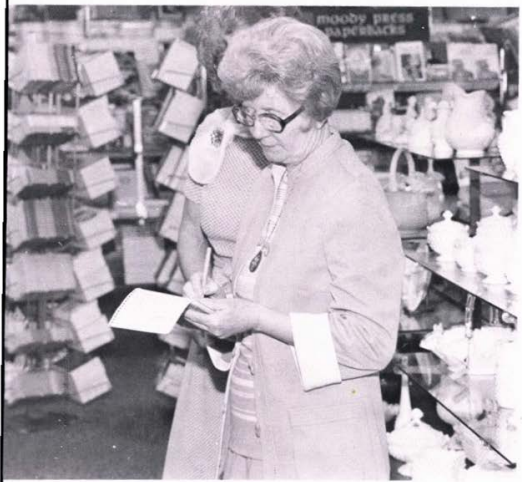

\section{Growth Is Seen In Bookstore}

Bernice Mick was born in Clendenin. West Virginia. She came to a saving knowledge of Jesus Christ as a teenager. Following High School, her father died and she became a supporter for her mother and seven brothers and sisters. For several years she worked in a drugstore and learned much about merchandising. After she had gained experience in merchandising, the Lord enabled her to attend Baptist Bible Seminary in Johnson City. New York. Transferring to Cedarville College in 1953, she graduated in the diploma program in 1955. Prior to graduation, she became involved in the enterprise of the college bookstore. Using her past preparation, she nurtured the fledgling store. The bookstore was first located in what is now the reception room of the Administration Building. It was then moved to the basement of the Fine Arts Building where a snack shop, laundry room. and student lounge were part of the bookstore operation. Continuing to outgrow its cramped quarters, the bookstore and company moved to the first floor of Patterson Hall. The final move came in 1965 when the store was established in one-half of Milner Hall. The store has nearly taken over Milner Hall with only a few rooms used for other purposes. Miss Mick has learned to use every possible square inch in the space that is given her. Books are ordered from over 500 companies. Far from being "just another college bookstore", the Cedarville College Bookstore is known across the United States and around the world. For helping Cedarville College grow into a recognized Christian Liberal Arts College and effectively serving the student body, faculty. staff. community, missionaries, visitors, and pastors, we, of the yearbook staff dedicate the 1978 Miracle to Miss Bernice Mick. 

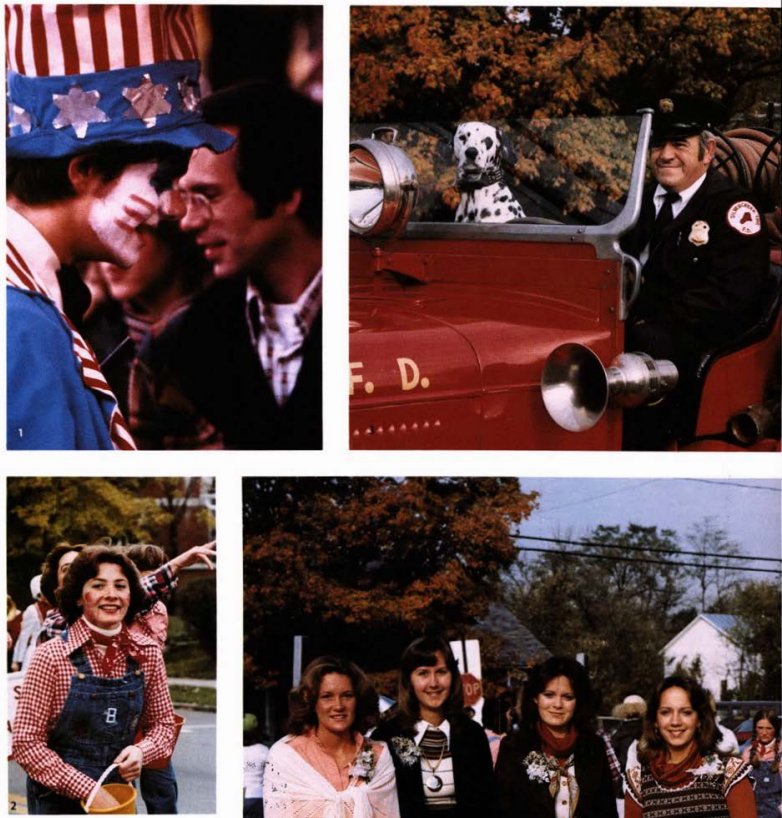

1. Uncle Sam (John Mohler) tries to enlist future Cedarville College students. 2. Barb Adams helps distribute candy to the kids.

3. Silvercreeks "Sparky" comes to en hance the Homecoming festivities. 4. The 77 Homecoming court stops for a quick publicity photo: Karen Heyburn. Freshman: Diane DeNicola, Senior; Judy Brown, Sophomore: Cindy Hall, Junior.

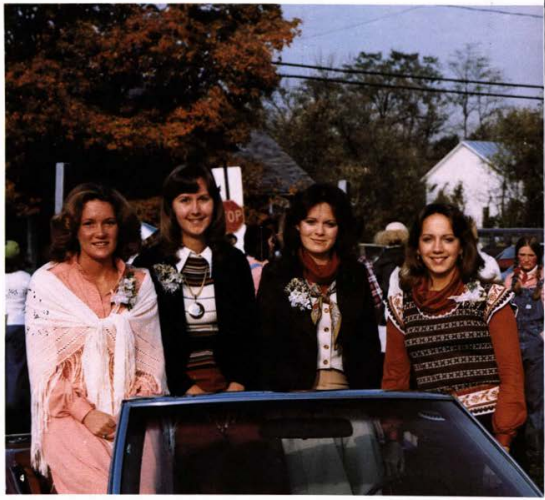



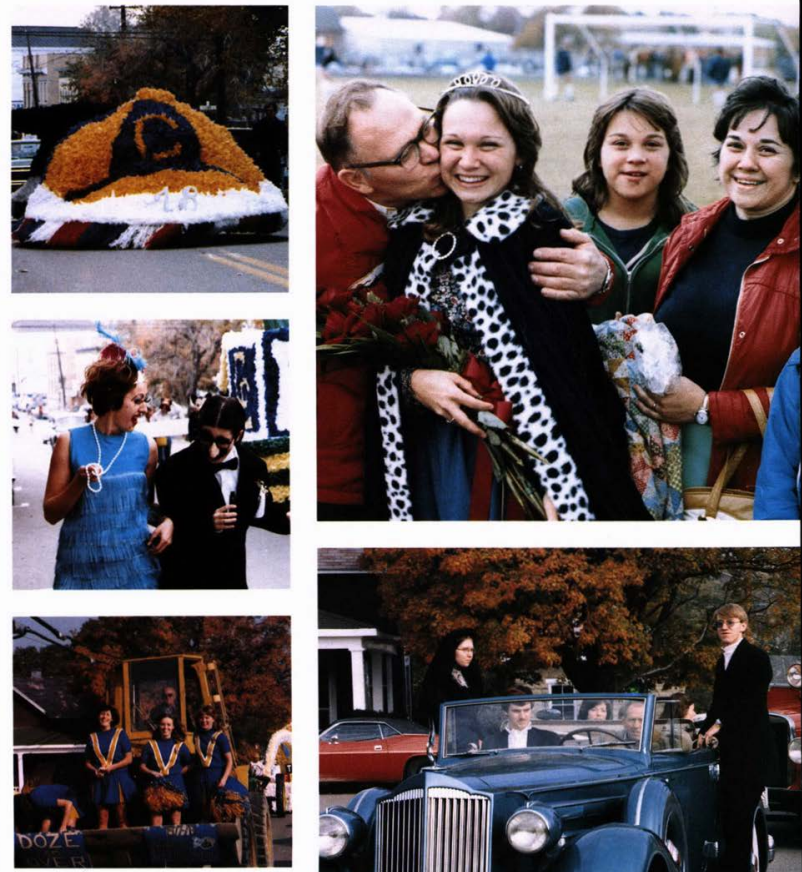

1. Andrea MacDermaid gets a kiss from her father as she shares with her family her joy in being elected Homecoming Queen.

2. The nostalgic theme is visible throughout the parade.

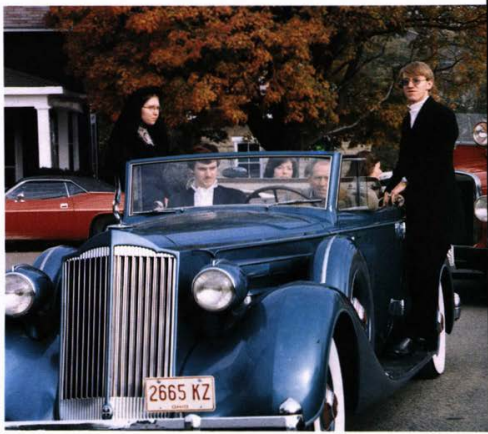




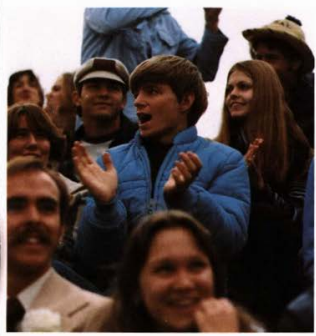

"The Way We Were"
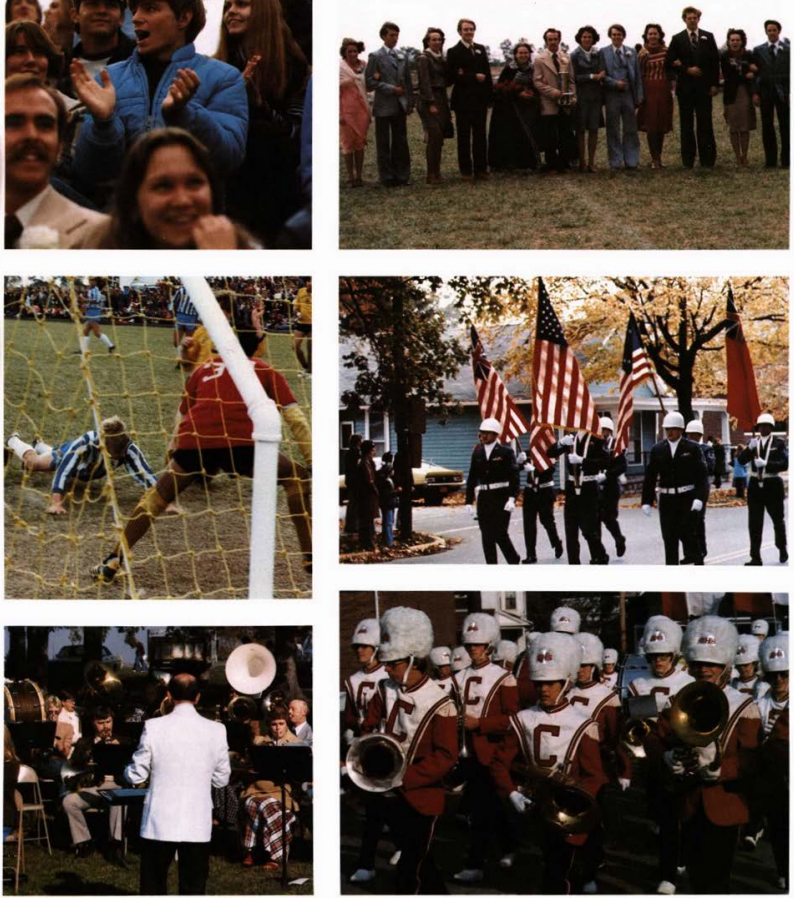


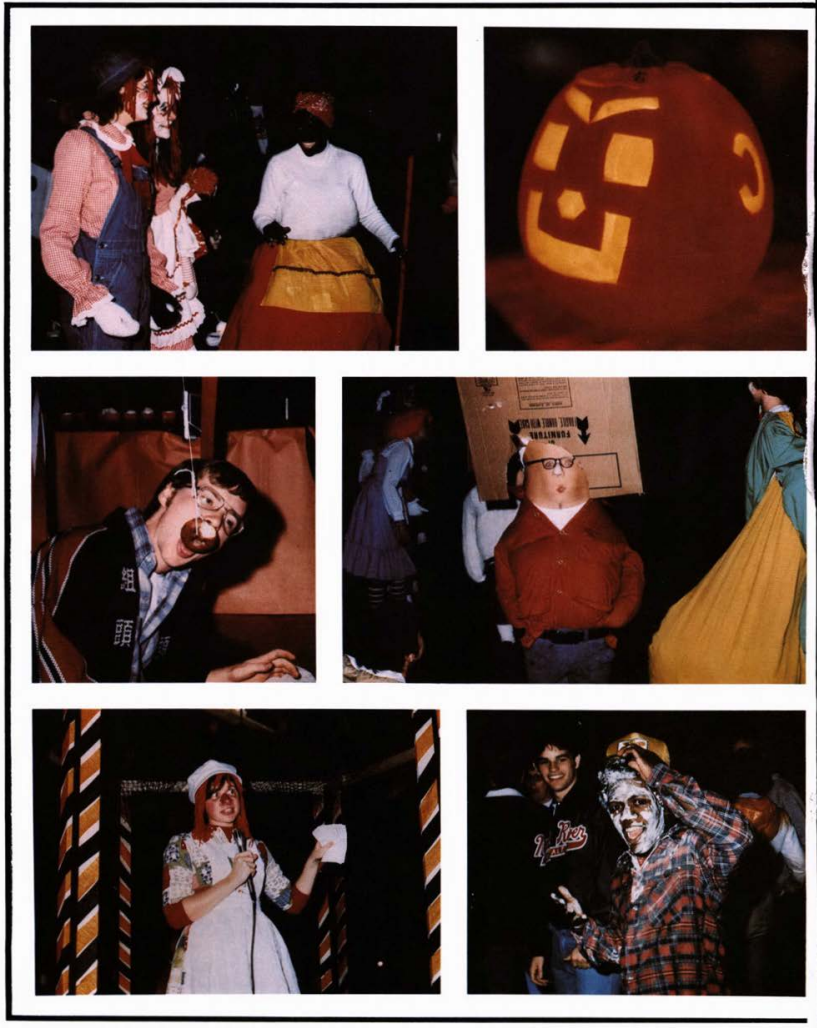




\section{Performers Present Excellent Artistry}

The 1977-78 Artist-Lecture Series provides the College Family with culturally superior performances

with a variety of styles. The

students' interaction is chiefly

inward during the concert or lecture and becomes outward as

the student discusses what was said or heard with other students.

God created music so that man could glorify God. Through common grace, man can simultaneously glorify God and be entertained

by this God-created medium. The expression of our innermost feelings and unutterable thoughts can often be expressed in various types of music. God also gave man the ability to articulate

His Word and to rightly interpret

it with guidance from the Holy Spirit. The interaction of ideas is a gift which can cause man to grow spiritually and intellectually. The spoken word,

instrumental music, and vocal music are all gifts from the Creator. Obviously, our stewardship demands that we be involved in these areas as performers, lecturers, or spectators.

1. Robert Hale and Dean Wilder have been traveling as a vocal duo since 1966 .

2. The varied talents of the Kriegers range from instrumental and vocal solos to ensemble singing.

3. Christine Wyrtzen displays her artistry as she plays and sings her own composition.

4. Cedarville graduate Tim Kauffman possesses a wide voice range enabling him to sing bass and first tenor.

5. Duo-piano team Frances and Richard Hadden tell of their unique musical excursion to the People's Republic of China.

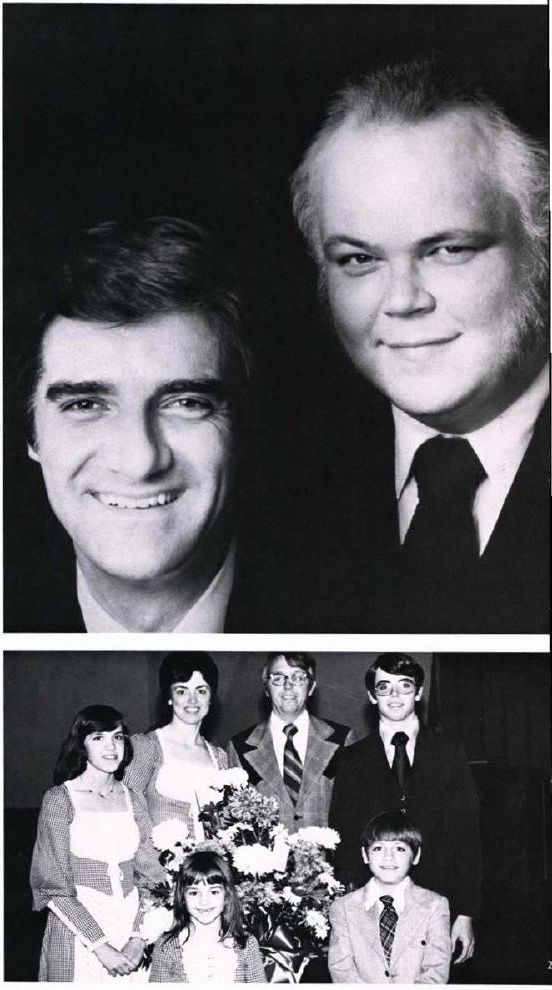



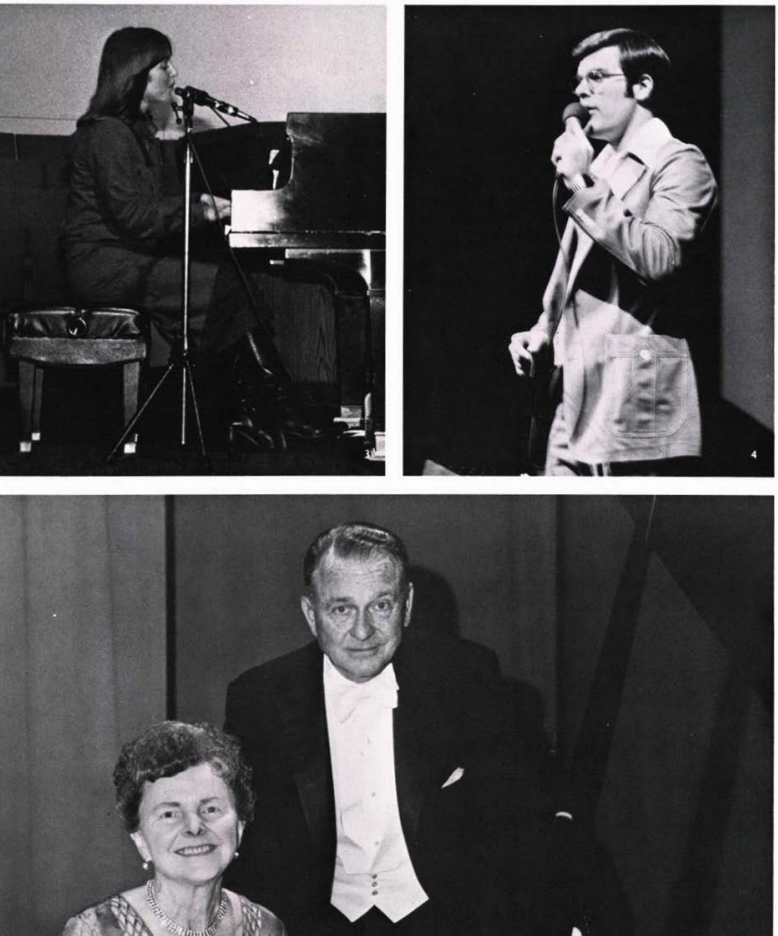
Ed Lyman, tenor solist

Organ Dedication Concert by David Brackley

Soundsalive

The Haddens - "Expressions in Music and Diplomacy"

The Springfield Symphony Woodwind Quintet

The Krieger Family

Daniel Majeske, violin soloist

Robert Hale/Dean Wilder, vocal duo

Staley Foundation Lectureship - Dr. Kenneth Gangel

Robert Nagel, trumpet soloist

Christine Wyrtzen, gospel recording artist

Feminar - Mrs. Dallas Green

Sam Rotman, piano soloist

Shirley Close, mezzo soprano

Richard Collins, piano soloist

Tim Kautfman, gospel recording artist

IN-FORUM - Dr. Victor Matthews on apologetics

Bill Pearce, radio personality
Oct. 1

14

24

28

Nov. 11

15

Dec 2

Jan. 6

10-13

20

Feb. 10

$13-15$

Mar. 4

Mar. 4

28

Apr. 20

May 27
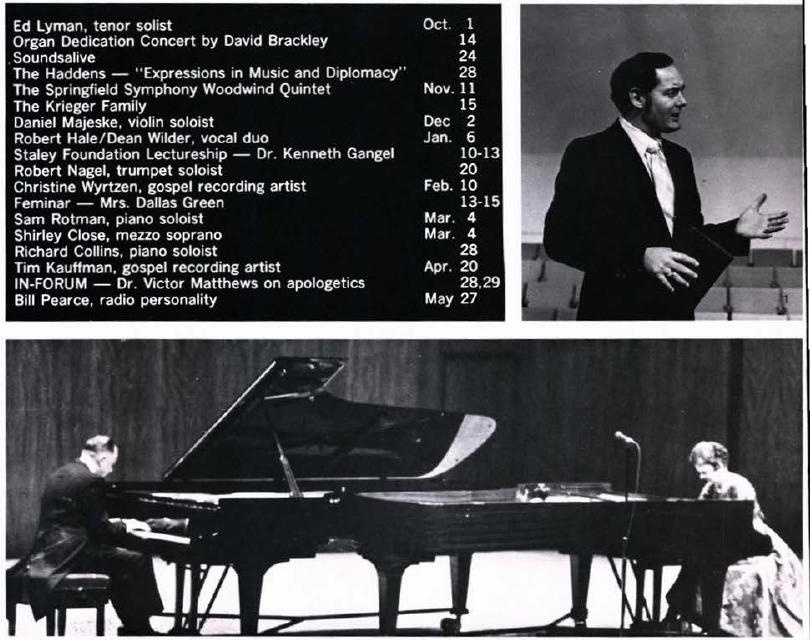

1. Dr. Kenneth Gangel, President of Miami Christian College, is the 1978

Staley Foundation Lecturer on the subject of Biblical Christian Leadership.

2. Piano duo Frances and Richard

Hadden display their musical artistry.

3. The Springfield Symphony Woodwind

Quintet pose for a publicity photo.

4. Fort Wayne's Blackhawk Baptist Church sponsors Soundsalive.

5. Radio personality Bill Pierce gives an enjoyable and God-honoring concert.

6. Daniel Majeske, a renowned violinist. demonstrates his pizzacato technique. 7. The Springfield Symphony Woodwind Quintet performs with expert timing and precision.

8. Mezzo soprano Shirley Close gives Cedarville a pleasurable taste of operatic

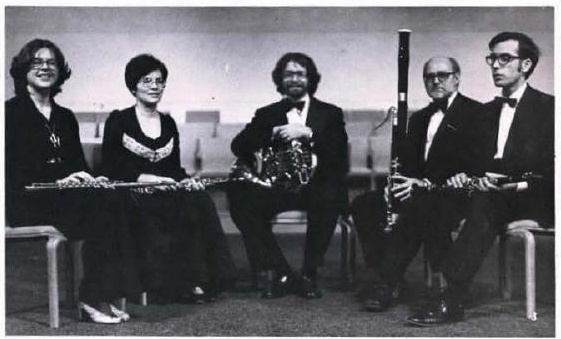



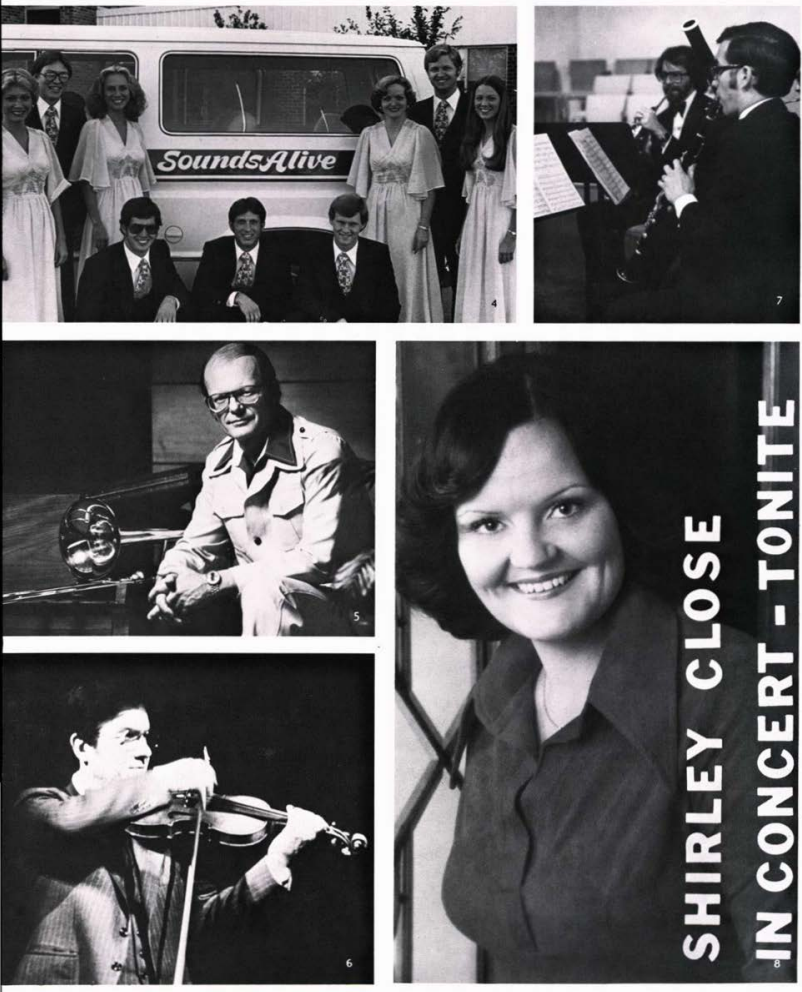
"In the Doghouse"

"It is Finished"

"Concertina"

"Bedtime Story"

"The Outlaw"

"How Rich I Am"

"If Only"

"Trouble In River City"

"Certs"

"You Light Up My Life" "If"
"My. Jesus I Love Thee"

\section{THE ACTS}

Janet Davis

Dave Herne

Joanne Blasdell

P.J. Shanks

Tim Moore

Bruce Sever

Cozette Wicks

Trudy Tangblade

David Lawhead

Steve Keller

Sue Folkman

Marla Fortney

Joanne Bradshaw

Lisa Ramsey

Jim Hunt
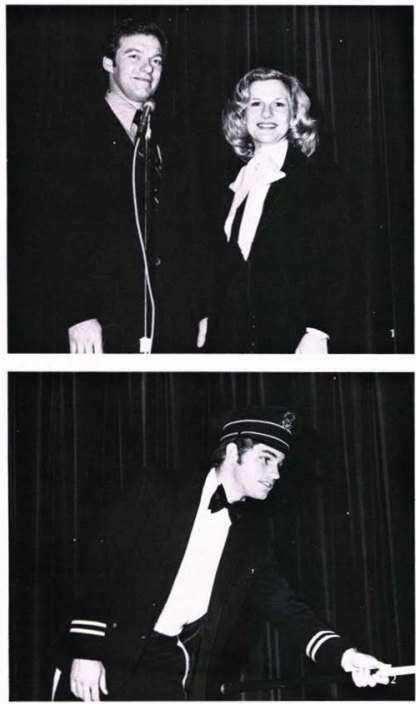
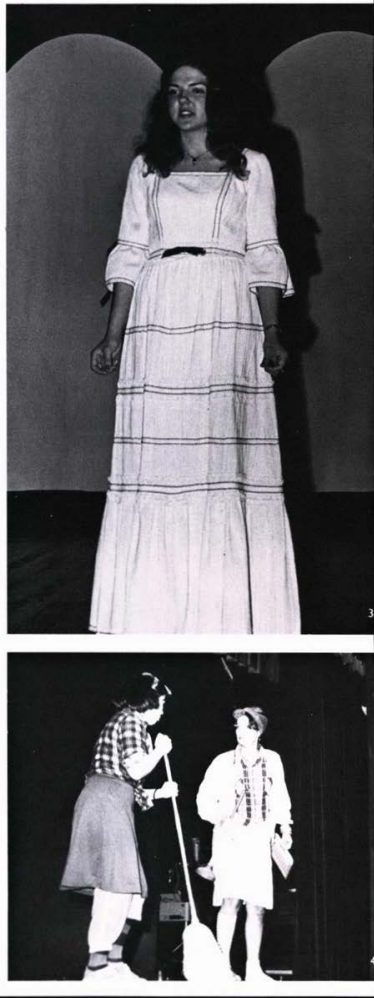


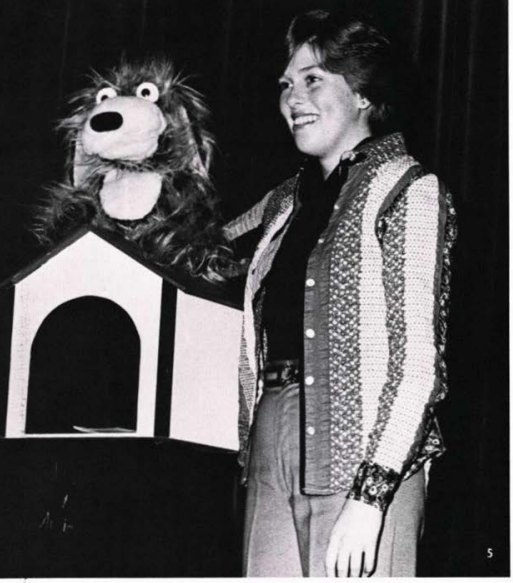

\section{Ventriloquist Wins \\ New Student Talent Night}

Ventriloquist Janet Davis is the winner of the annual Student Body Project Talent Night. The Talent Night is held on November 5, 1977 in Alford Auditorium. Hosts Drs. Jim and Sharon Biddle introduce twelve intriguing acts that include vocal and instrumental solos, comedy sketches, and an excerpt from a Broadway show. The interaction is clearly visible as students show their approval or disapproval at the end of each. After the ballots are counted, Student Body Project Chairman Scott Browne gives prizes to the top three acts.

1. Drs. Jim and Sharon Biddle emcee the evening of entertainment. 2. Second place winner David Lawhead proclaims "Trouble in River City." 3. Third place winner Trudy Tangblade dramatizes a story of a little girl and the sudden death of her brother.

4. Cherie Watts and Lila Terlouw await that "special phone call."

5. First place winner Janet Davis achieves perfection as a ventriloquist. 6. Tim Moore and Bruce Sever sing. "The Outlaw."

7. The Cedarville Certs' Sweeties test their ammunition against halitosis.

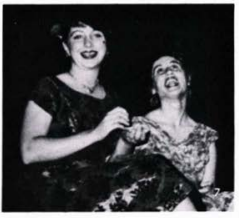




\section{Wilder's 'Our Town' Projects Realism}

Thornton Wilder's "Our Town" takes place in Grover's Corners.

New Hampshire at the turn of

the twentieth century. The details have been purposely generalized so that you can imagine your own town and family, allowing the story to

overlap with your life. This explains Wilder's use of a nearly bare stage and minimal properties. The play is classified

as realism, but only as "Our Town" becomes real to you. As with any work of art, your point of contact as observer assumes

the role of evaluator as well.

The director encourages you to

seek not only entertainment from the performance but also an insight into Wilder's philosophy and value system as

it is revealed in the play. (reprinted from comments made by Director Rebecca Baker)

1. Childhood sweethearts Emily Webb and George Gibbs (Lori LaHaye and Jeff Kohns) enter wedded bliss.

2. John Duff, Don Adamson, and Jeff Kohns philosophize about life in "Our Town."

3. Emily Webb (Lori LaHaye) arrives in the graveyard and learns of the new life after death. The townspeople inform her that she sould not try to relive her past. 4. Tracy Knight, playing the part of the "Stage Manager", receives a last-minute touch-up on his make-up.

5. Mrs. Webb, Mrs. Soames, and Mrs. Gibbs (Debbie Ransom, Lorelei Rhines. and Susan Justice) converse about love and marriage.

6. Director Rebecca Baker exhibits pain in her left arm.

7. Mr. and Mrs. Webb (Tim Snell and Debbie Ransom) are the proud parents of the Bride-to-be.
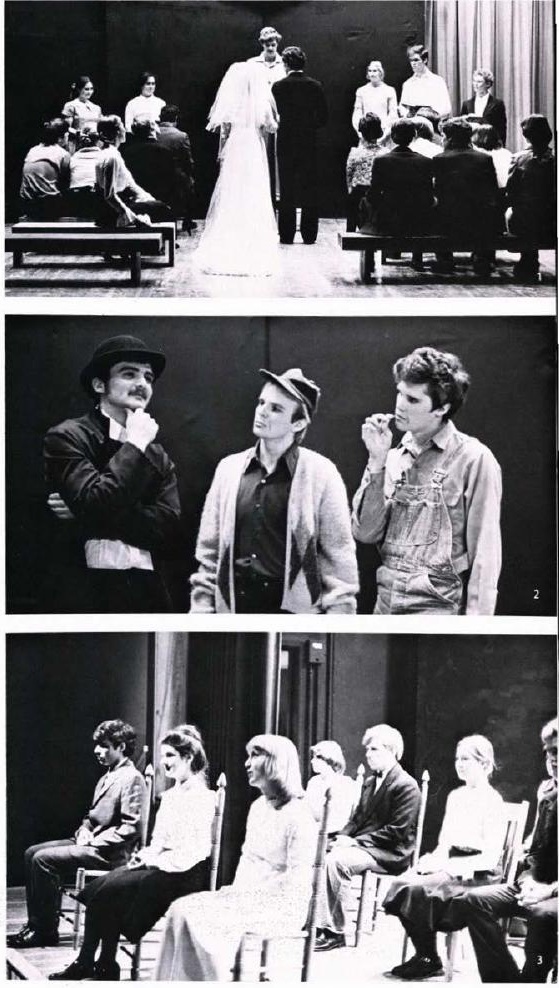


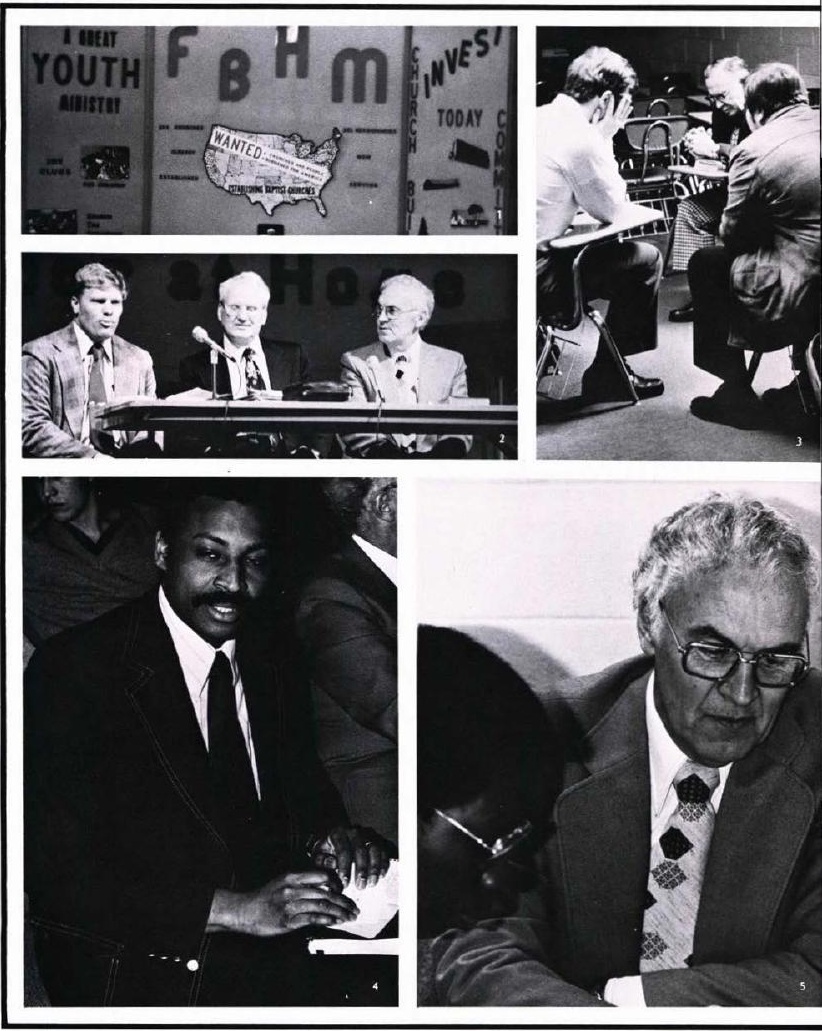




\section{'Fiddler' - A Musical Masterpiece}

Excerpts of Bill Anderson's review are reprinted by permission of the editorial staft of the WHISPERING CEDARS.

The MENC's recent production of the Joseph Stein-Jerry Bock-

Sheldon Harnick musical "Fiddler on the Roof" proved again that there is a place for musical theatre at Cedarville. With its memorable tunes like "Tradition," " Sabbath Prayer," and "Sunrise, Sunset," the

production was one which exuded excellence in all of its facets. Much of the credit for this outstanding achievement belongs to the projects mastermind, Richard Luedeke, whose brilliant direction and faithful recreation of Jerome Robbins' original choreography resulted in a unified experience that was both dramatically and musically superb. Mr. Luedeke was aided by a very capable CoDirector, Rosalie Eaton.

Producer Dawn Spencer's work was clearly visible in the

program and she handled the ticket sales and publicity quite admirably. Conductor John Mohler performed with precision and professionalism.

1. Four who dared

2. After making a wedding match for daughter Tzeitel and Lazar Wolf ( $R$

Harper). Tevye (J. Raber) and Lazar sing. "To Life, To Life, L'Chaim."

3. The people of Anatevka celebrate the wedding of Tzeitel and Motel

4. Tevye (J. Raber) tells Golde (L. West) about his haunting nightmare.

5. Perchik (P. Miller) serenades Hodel (J. Riter) with the enchanting love song. "Now I Have Everything."

6. Terrifying the audience, ghost FrumaSarah ( $K$. Jones) warns Tevye that his daughter Tzeitel should not marry her husband Lazar Wolf.
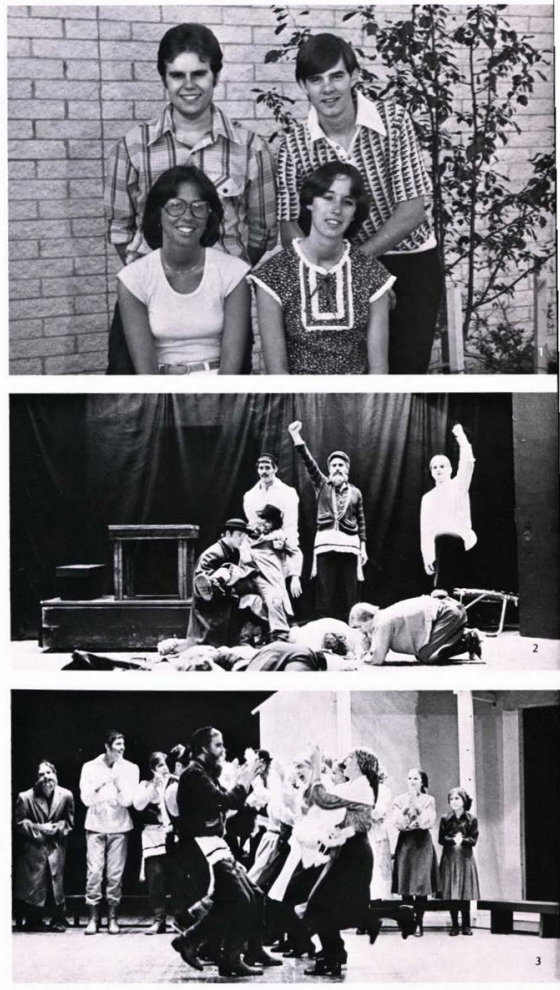


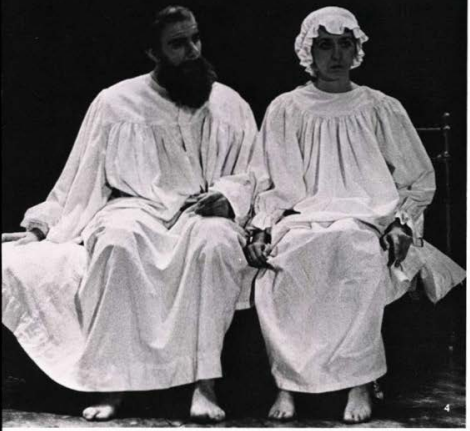

\section{THE CAST}

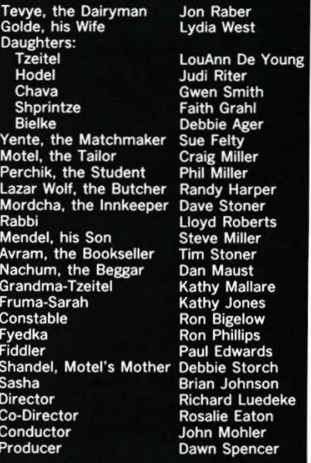
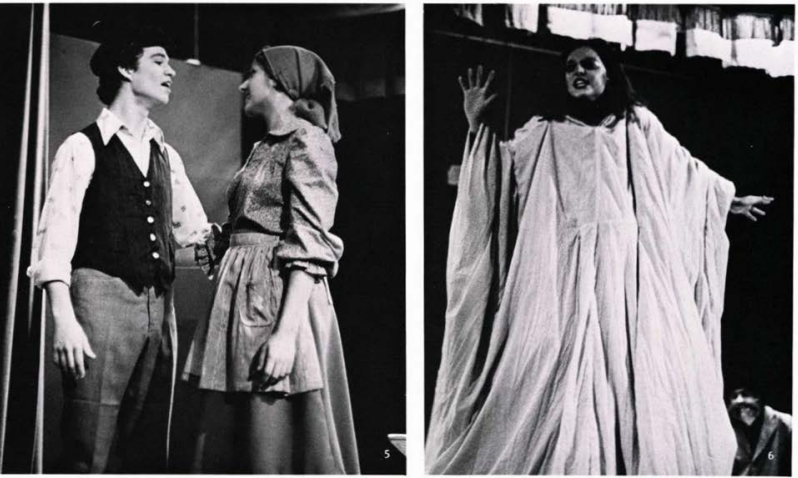


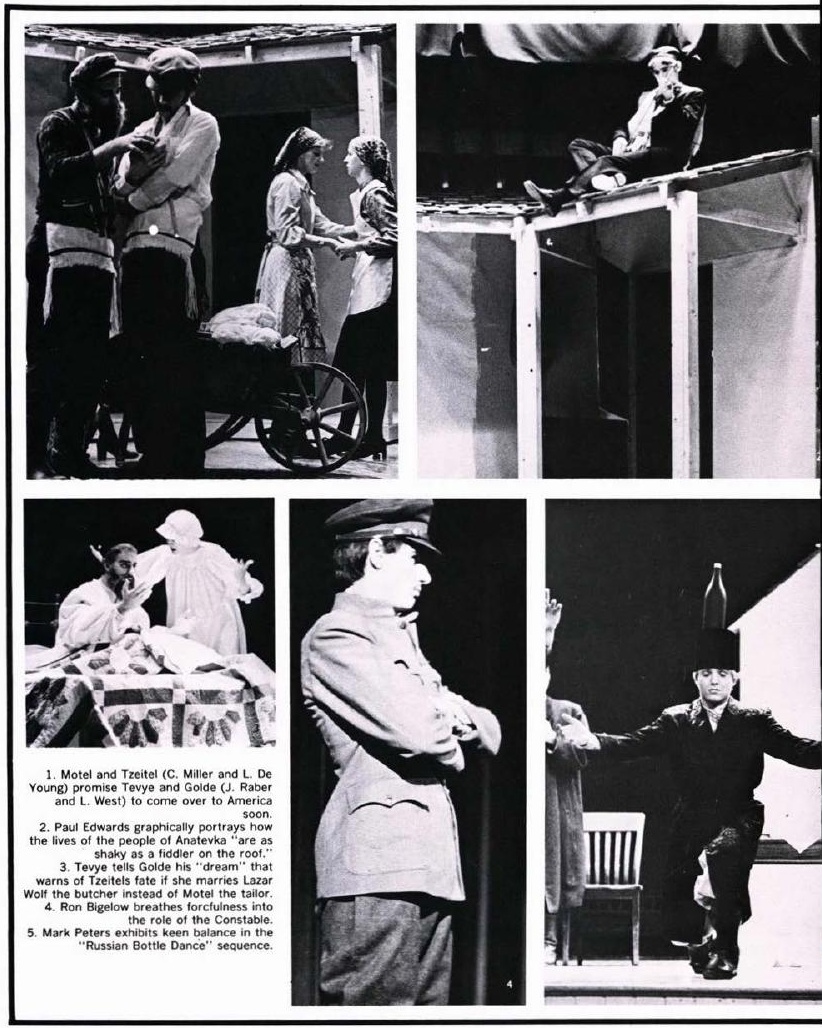



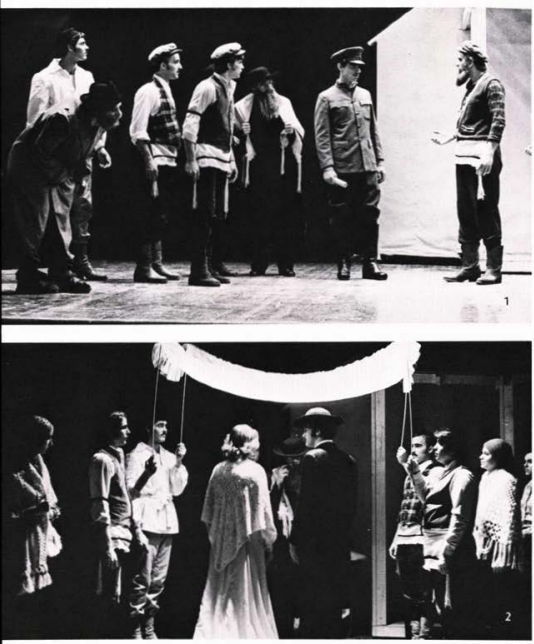

Cello

Bass

Flute-Piccolo

Oboe.

Clarinet

Trumpet

Trombone

French Horn

Accordion

Percussion

THE ORCHESTRA

Violins

Mary Stahl

Sandra Moore

Margie Filmer

Mary Wallace

Linda Divan

F. Holcker

Nancy Tillman

Gene Pummel

Brenda Apple Adrienne McClure

Cathy Heatly Joyce Cartwright

Loyd Stigers

Dave Messenger

Matt Vincent

Steve Myers

Mary Ryburg

Jim Luce

Allen Webber

Priscilla Taylor

Like "You're a Good Man, Charlie Brown," last spring. "Fiddler on the Roof" was another daring yet triumphant undertaking for $\mathrm{Mr}$. Luedeke, his cast, and his crew. They deserve the loudest of bravos for successfully achieving that trait which is all too rare in musical theatre, perfection.

Man is a total being and thus God created the arts to reveal beauty to His creature Man. Appreciation of the arts and involvement with them is essential for members of the body of Christ. The cultural mandate given by God implies the use of our God-given gifts in the arts.

1. Constable Ron Bigelow tells Tevye (J. Raber) and the other Villagers (D. Maust. D. Cobb, D. Stoner, T. Stoner, and L. Roberts) that they have "three days" to pack up and leave Anatevka.

2. A solemn moment is shared by all in Motel and Tzeitel's traditional Jewish canopy wedding ceremony.

3. The final curtain call allows the audience to express their appreciation to the entire cast and crew. (Pictured: J. Riter, P. Miller, J. Raber, L. West, R. Phillips, G. Smith). 


\section{Alpha Chi Presents 'Vaudeville' Talent Night}

Alpha Chi, the leading men's

organization on campus, presents ten acts in a night of vaudeville entertainment. Alpha Chi Vice-President Phil Miller introduces each act and asks audience members to vote for the two best acts in two categories: talent and entertainment. First prize in the talent category goes to ventriloquist Janet Davis, following up her earlier triumph in the New Student Talent Night sponsered by Student Body

Project. Brenda Apple and

Rosalie Eaton are awarded

second prize in the talent category for their rendition of Claude Bolling's "'Sentimentale from Suite for Flute and Jazz Piano." First prize in the entertainment division goes to

Rich Luedeke and Lydia West

for their pantomime, "Les Jaseroques." Stephanie Mesner

and Kim Faull achieve second prize in the entertainment division with a multimedia presentation, "The Exodus from Cedar Park."

1. Stephanie Mesner and Kim Faull lament the "Exodus from Cedar Park." 2. Anne Tawney and Beth Namy frollic in "Midnight at the Toy Shop."

3. Rich Luedeke and Lydia West attempt to send mime artist Marcel Marceau to the unemployment office. 4. The Norman Tabernacle Choir prepares to perform their all-new "Development Cantata."

5. Loyd Stigers performs a Flor Peeters"

6. Second Place, talent category Eaton \& B. Apple; First place, talent category, S. Decker, acc. J. Davis; First place, entertainment category. L. West \& R. Luedeke; Second Place. entertainment category. S. Mesner, acc. E. Wyse, \& K. Faull. 7. Janet Davis tells Archie that he is not ready for the bright lights of Hollywood.

8. Nancy Unroe gives her rendition of

the mournful ballad, "Send in the Clowns," made popular by folk singer Judy Collins.
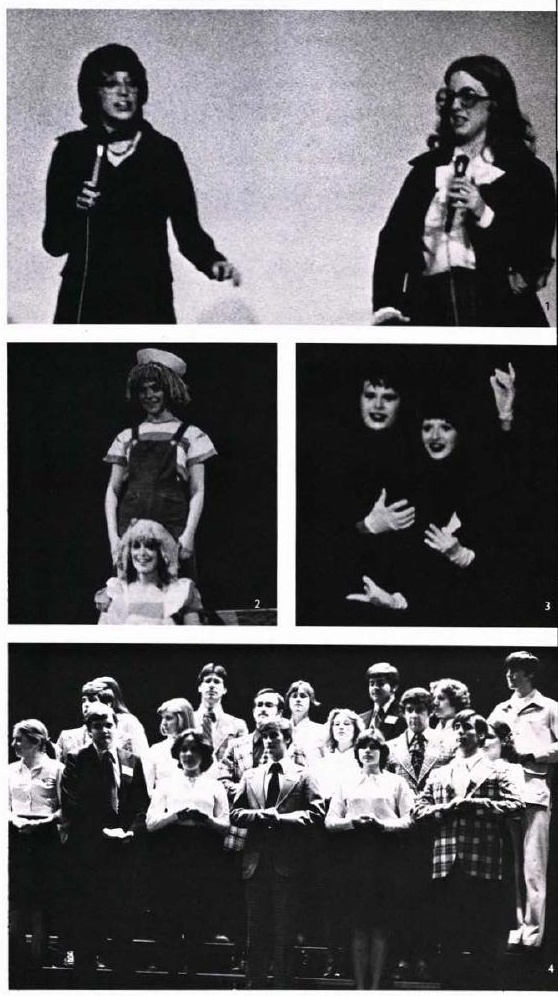


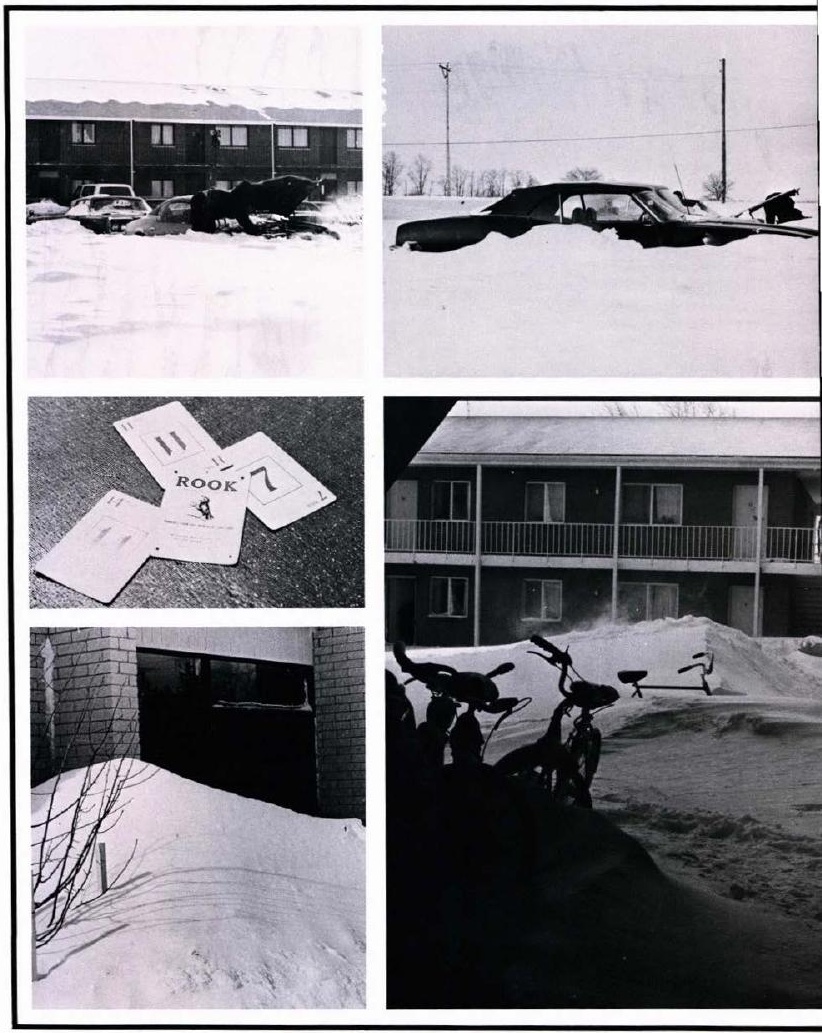




\section{Spring Is $A$ Special Event}

The 1978 spring season is a special event a Cedarville College. Various classes are held outdoors and the major college activity is basking in the rays of

the sun. Rockclimbing, picnics at John Bryan State Park, jogging, and softball are some of the many other activities that entice students from their rooms and the library.

Memories of one of the worst winters in southern Ohio history quickly fade into oblivion. The simple beauty of watching a tree leaf out or a flower bloom is one of the pleasures to the onset of spring. The ecological activity of God's creation is awesome and much can be learned by careful observation. It is the Christian's responsibility

to be aware of the other members of God's Creation. Man has been given dominion over the other creatures and

has the responsibility and privelege of subduing the earth and its inhabitants.

1. Steve Stange urges Jim Hunt to remain one bike's length behind him. 2. A local model shows off the latest in rockclimbing fashions from Paris.

3. Spring spawns the aesthetic nature in all of us as demonstrated by Dennis Gillenwater. 4. Mr. Grosh's outdoor class wonders if they can stop pretending to take notes for this candid picture.

5. David Cvetich gives someone a look they will never forget.

6. Dave Campbell and a friend initiate a Spring Quarter transfer student. 7. Craig Colas and Nancy Tenney try to stay ahead of the pack.

8. Tim Dunn and Keith Haas tell Arnold Schwarzneggar to step aside.

9. This is a common scene in early spring.

10. David Wickham exhibits the art of repelling.
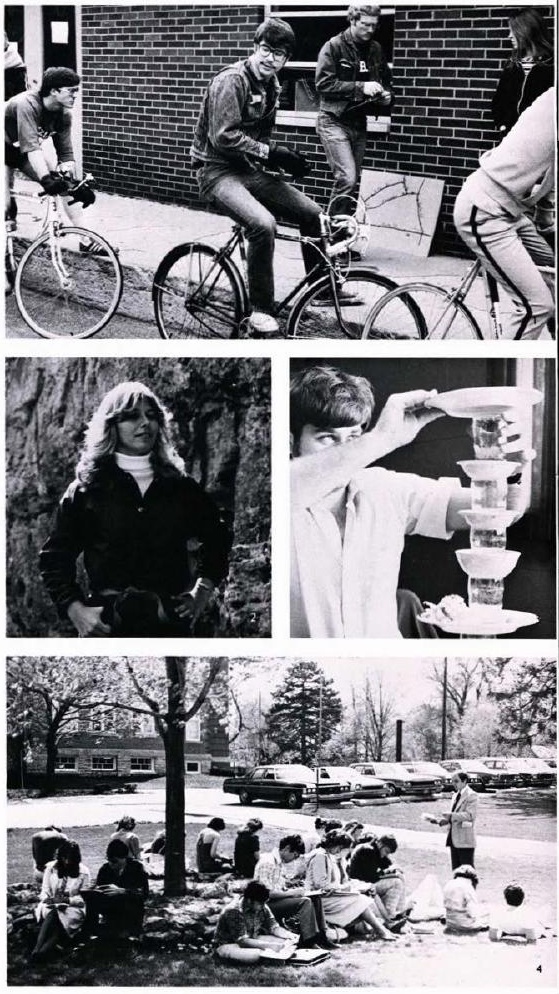

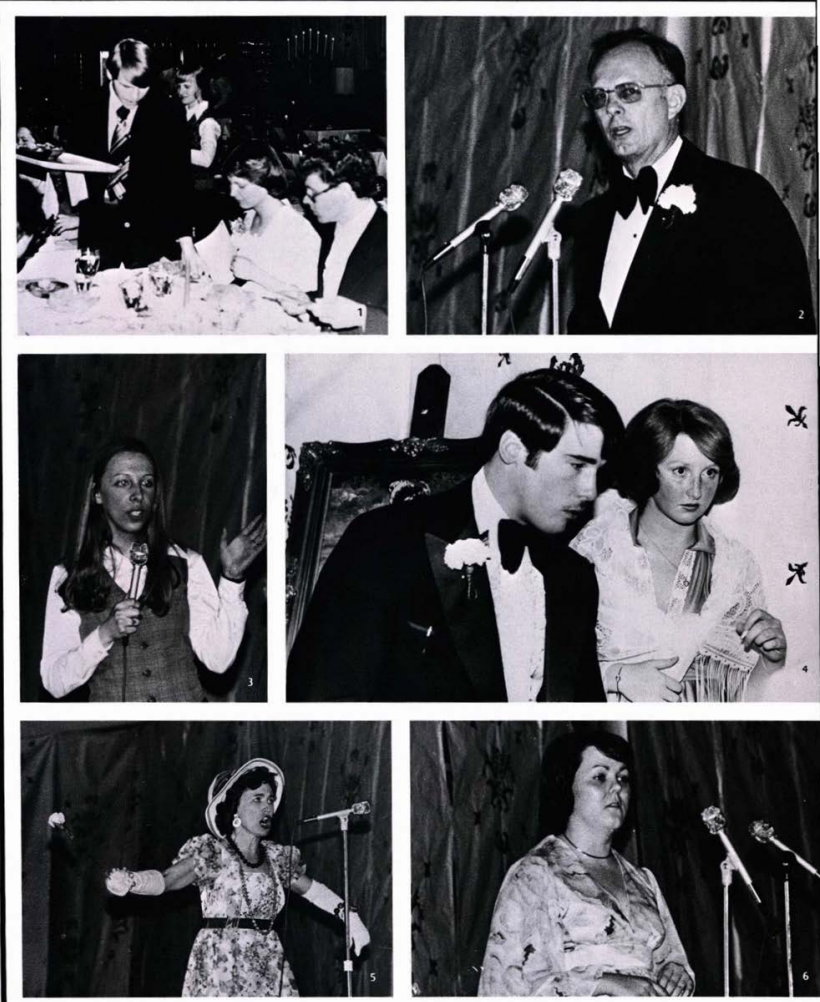


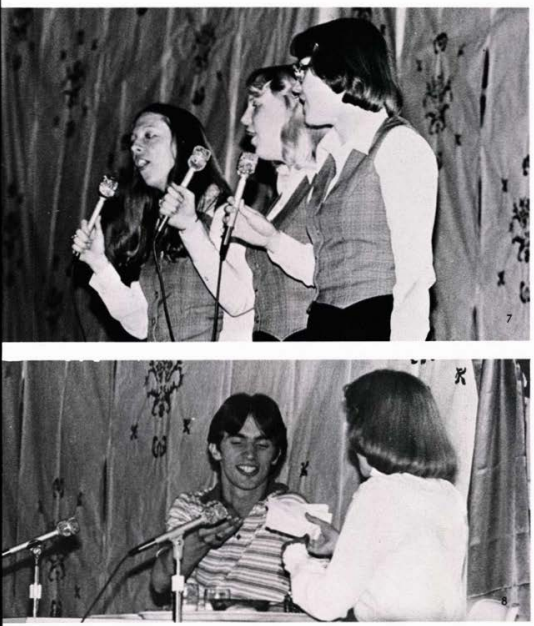

\section{Gamma Chi Adds}

\section{'A Touch Of Class'}

"A Touch of Class" is the mock theme of the annual Gamma Chi Banquet held in the gymnasium on April 14, 1978. Gamma Chi is a prominent women's organization on campus dedicated to service to the school. Dinner Music is admirably provided by a local harpist and flautist. After a savory supper, entertainment is largely provided by the women of Gamma Chi. Emcees Clifford Johnson and Jody Grosh introduce each vignette in a series of satire sketches about "class" at Cedarville College. Supplementary entertainment is provided by Living Hope and the renowned Norman Tabernacle Choir. The Choir performs their newest chart-buster, "Cantata", after returning from a whirlwind tour presenting the phenomenally successful "Development Cantata" to prospective Cedarville students and friends. The evening of frivality comes to a conclusion with the pronouncement that Cedarville men and women simply have "no class."

1. Waiter Mike Nelson shows his table that he has "class."

2. Emcee Clifford Johnson refuses to conduct a press conference at this time. 3. Joan Surso adds motions to her song. 4. Hostess Tammy Danec and Bouncer Jeff Conklin guard the entrance to the gym.

5. Emcee Jody Grosh model an outtit worn by Minnie Pearl for her debut at the Grand Ol' Opry House.

6. Gamma Chi President Nancy Drake introduces the evening of "class."

7. Living Hope sings "A Touch of Class" to the tune of "A Look of Love."

8. Ron Phillips endures the bad etiquette of Suzan Zink in a comedy sketch.

9. Carol Morgan and Dave Lawhead wonder if the food was cooked in our cafeteria. 


\section{Activities Characterize Cedar Weekend}

May 5, 6, 1978 is Cedar Weekend and characterized by numerous events and activities. The annual Honors Ceremony is held in the Chapel a 10:00 a.m.

on Friday. The convocation returns to its original format,

having the students on the Dean's Honor List receive their

awards individually. They also receive congratulations from the faculty in their respective departments. A women's tennis match against Wittenberg University is held in the afternoon followed by a men's NCCAA National Track Meet. G.B. Shaw's "Pygmalion", the spring play presented by the

Village Players, performs its second show at 8:00 p.m. on Friday evening in Alford Auditorium. Other Friday evening activities are an obstacle course and Bonfire at Cedar Lake and a Road Rally.

Saturday, May 6, is Cedar Day and is sponsored by Alpha Chi, a men's organization on campus. Academic an organization displays are set up in the gymnasium to aid in prospective student recrutiment. Chi Theta Pi, a health-science organization, sponsors the third annual Science Fair, given for area Christian High School students. Athletic competition continues as the women's softball team hosts the Ohio Valley League Tournament. The men's baseball team faces Tiffen

University while the men's tennis squad hosts Wilmington College.
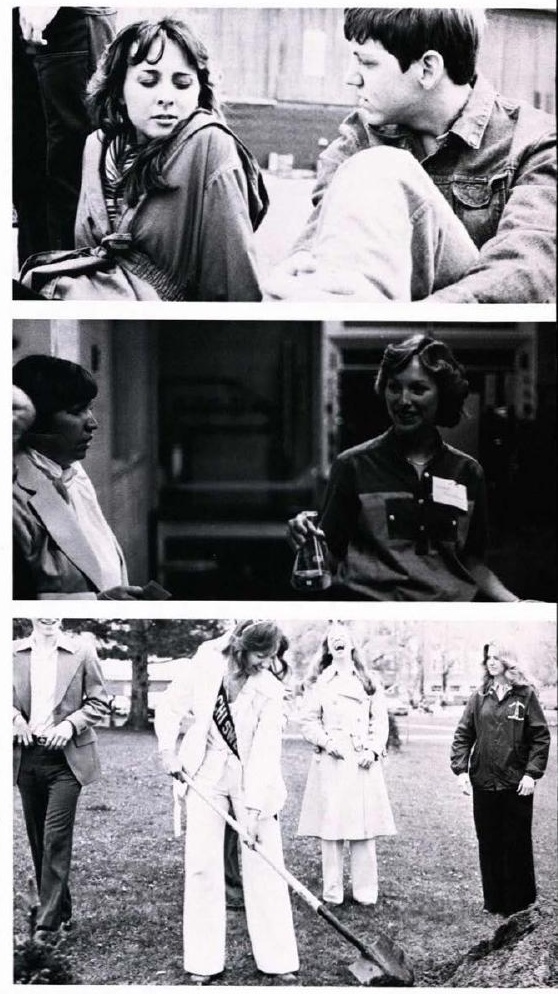

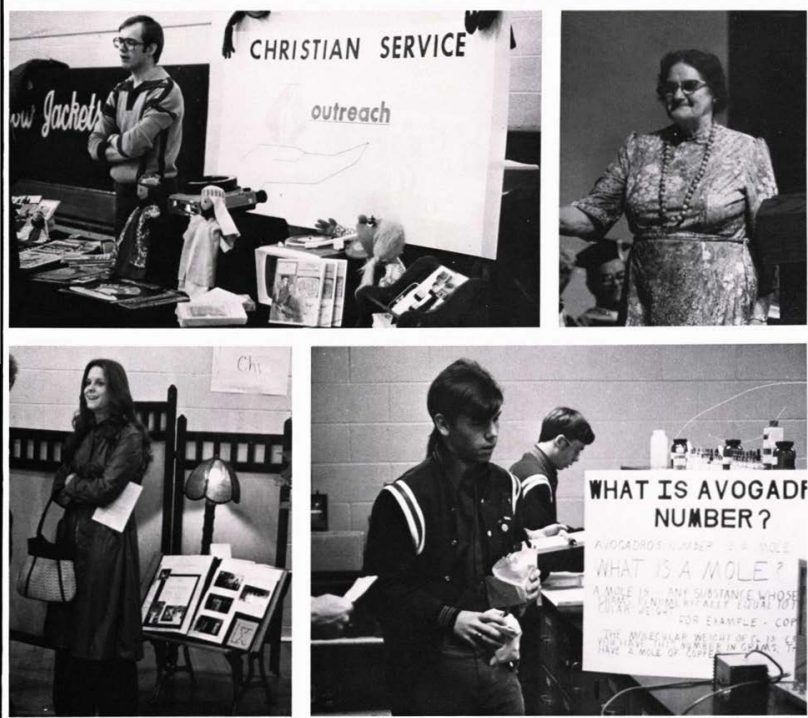
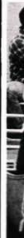

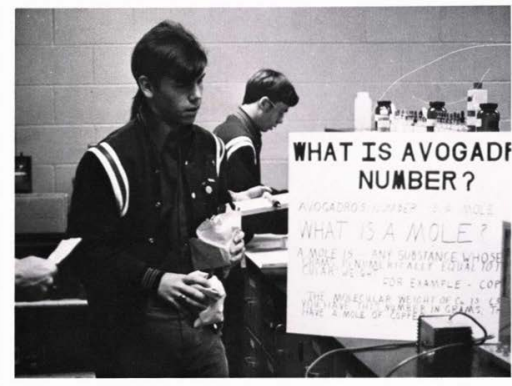

A matinee performance of "Pygamlion" is presented at 2:00 p.m. To conclude the day the Cedarville College Concert Choir is presented in its Home Concert. Director David Matson conducts his final concert as he plans to devote more time administrating the Department of Music.

(Editor's Note: Staff Member of the Year goes to Maddox Resident Advisor Beatrice Printy. Dr. Stanley Ballard, Chairman of the Department of Psychology is named Faculty Member of the Year." 


\section{THE CAST}

Henry Higgins Eliza Doolittle

Col. Pickering

Alfred Doolittle

Mrs. Eynsford-Hill

Clara Eynsford-Hil

Freddy Eynsford-Hill

Mrs. Higgins

Mrs. Pearce

Parlor Maid

Londoners

Stage Manager

Assistant

Director
Michael Brumbaugh

Desiree Kirk

John Duff

Tim Filler

Jan Kauffman

Peggy Harrell

Jim Leightenheimer

Suzy Vonada

Janice Zachary

Suzan Zink

Dan Maust

Don Adamson

Joel Veldt

Dale Wilson

Trudy Tangblade

Linda Burchett

Sandi Roth

Dawn Curtis

Lisa McClure

Jennifer Seevers

Robert Bragg

Don Adamson

Rebecca Baker, M.A.
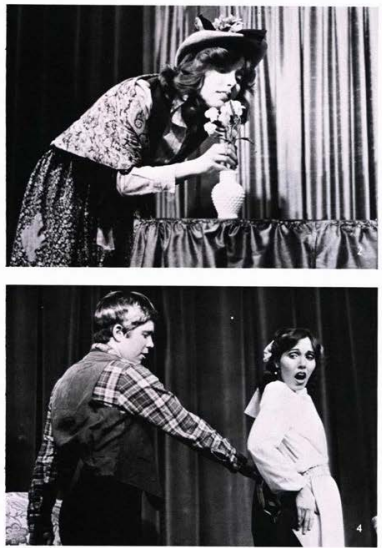

4

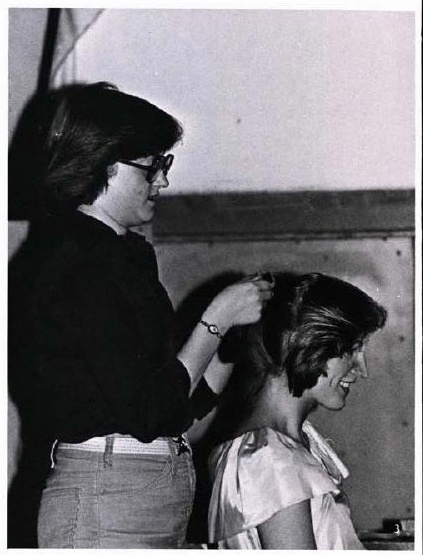




\section{Audience Receptive To G.B. Shaw's 'Pygmalion'}

The Cedarville College audience is receptive to the Village Players' spring production, G.B. Shaw's "Pygmalion" presented May 4-6, 1978. The play revolves around the attempt to civilize the rough Eliza Doolittle. The superb direction of Mrs. Rebecca Baker is observed throughout the theatrical production. Miss Kirk shines as the irrepressible, indomitable. and uncivilized Eliza Doolittle. Her transformation at the conclusion of the play is nothing short of remarkable. Mr.

Brumbaugh exudes confidence as the determined Professor Henry Higgins. The hard work and long hours of the cast and crew is clearly evident and all involved are commended.

1. With mounting excitement, Dawn Curtis awaits her theatrical debut as a Londoner.

2. Desiree Kirk exhibits a certain sensitivity as the rough Eliza Doolittle. 3. Make-up artist Peggy Kamphausen puts the final touches on Peggy Harrell's coiffure.

4. Alfred Doolittle (T, Filler) takes Eliza (D. Kirk) by surprise.

5. The clever Henry Higgins (M. Brumbaugh) interacts with a skeptical Colonel Pickering.

6. Eliza Doolittle displays her new image. 7. The Londoners conduct a street meeting with Mrs. Eynsford-Hill (J.

Kauffman) giving Freddy ( $J$.

Lieghtenheimer) a disparaging look.

8. Londoner Dan Maust demonstrates the closeness of a "Schick shave." 


\section{Johnny Hall Entertains, Ministers At J.S. Banquet}

May 12 is the date of the 1978 Junior-Senior Banquet sponsored by the Class of 1979 . The banquet is held at the Ohio

State University's Fawcett

Center for Tomorrow in Columbus, Ohio. Arriving at 7:30

p.m., the guests fellowship in the foyer of the Center. Dinner is served at $8: 00 \mathrm{p} . \mathrm{m}$. The menu

includes fruit cup, roast beef,

green beans, baked potato, tossed salad, rolls, fruit pie, and

your choice of beverage. preferably milk.

The program portion of the evening is held in a comfortable auditorium in the Center. A

multi-media presentation is dedicated to all members of the

Class of 1978. Karin Angel narrates the slide presentation that includes visual representations of many seniors doing what comes naturally. Junior Class President John

Potter makes the necessary acknowledgements and introduces Johnny Hall, a gospel recording artist. Mr. Hall entertains with vigor and ministers with power. His love for Jesus Christ is embodied in his music and he provides the perfect conclusion to a mosemost enjoyable evening.

1. Joyce Wheeler checks for dandruff in Steve Willsey's hair

2. Karin Angel shares a happy moment with Mary Forsten.

3. Junior Class President Jahn Potter agrees to give a press conference following the program.

4. Paul Edwards is glad that Ginny Decker takes Geritol.

\section{"I Will Be With Thee." Isaiah 43:2}
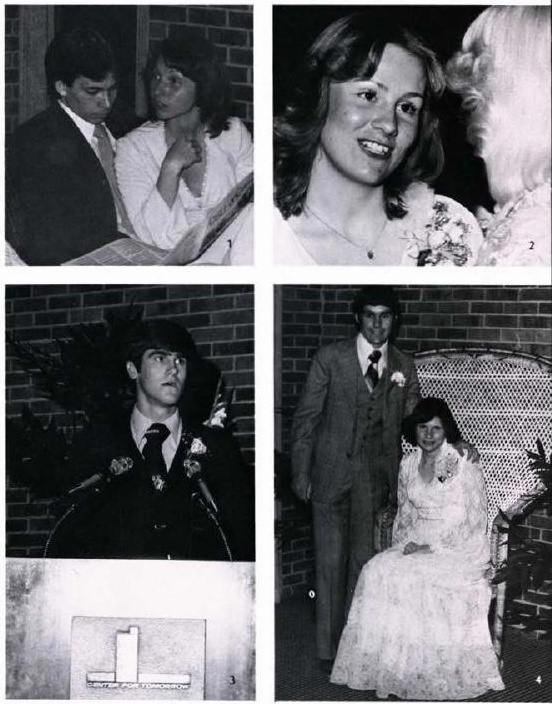

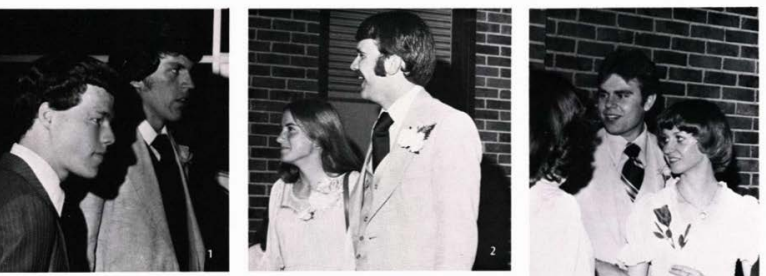

$\pm d$
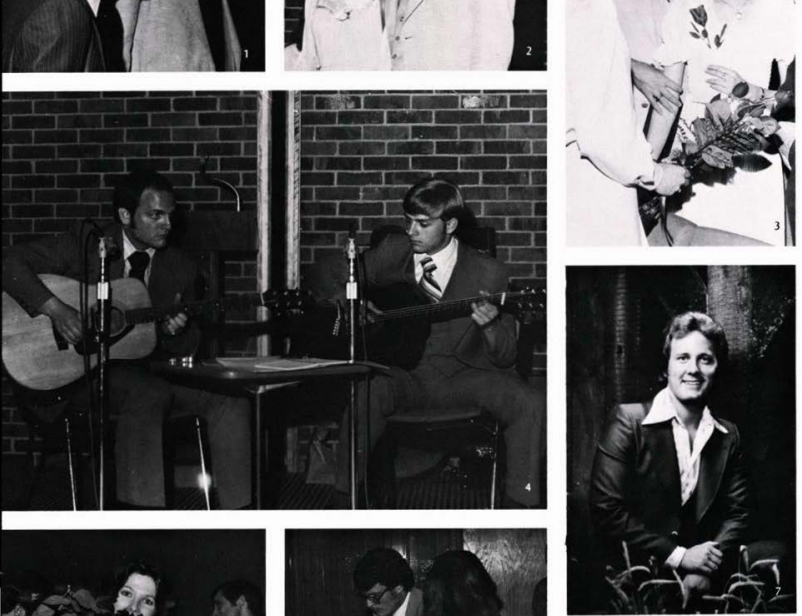

1. Dave Ormsbee and Dave Burtner converse with Gary and Becky Kuhn. 2. A stale joke gets a smirk from Amy Ross and a chuckle from Craig Miller. 3. Rich Luedeke and Lydia West share reminiscences with a friend.

4. Nick Linamen and Mike Stephens provide pleasing dinner music.

5. Cherie Watts exclaims, "Ole!"

6. Dan Hicks drains the punchbowl.

7. Johnny Hall is a contemporary gospel recording artist. 

The Trusteed

of

Cedanille College axe pleased to announce

the appointment of

Paul Dixan, M. Dire.

as President

and

the appointment of

Lames $\mathscr{T}$. Eenemiah, $\mathscr{D} . \mathscr{D}$., Litt. $\mathscr{D}$.

\author{
as Chancellax \\ of \\ Cedanille College \\ completed Seplembex 15, 1978.
}

The txansition in administration will be 


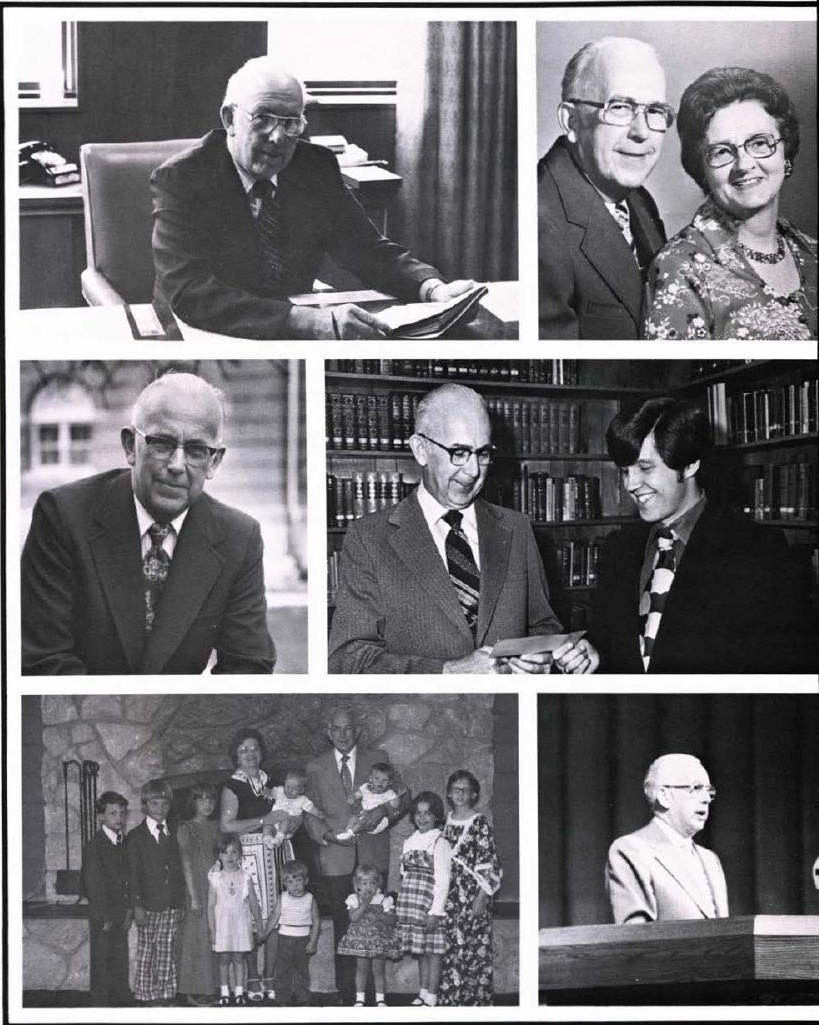



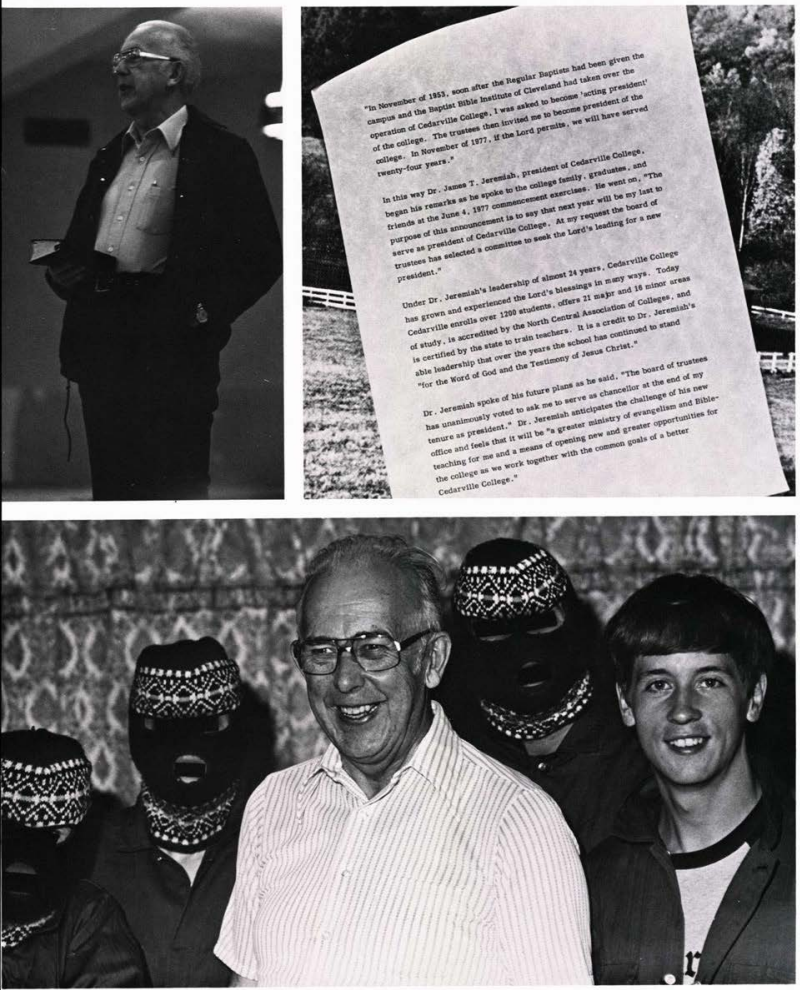


\section{$5 x^{7} 63$}

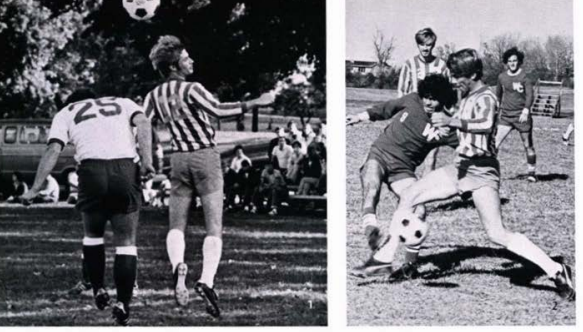

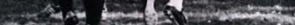
$x+3=$

This

.

हागाए

20.6.

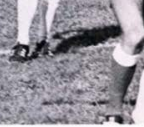

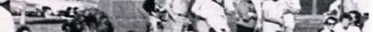

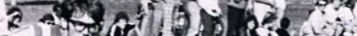

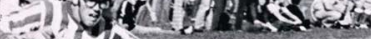
ing $\Rightarrow$
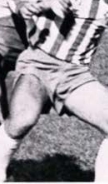

in

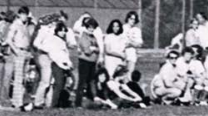
25

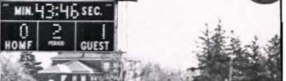

Sर:

ine Heilie.

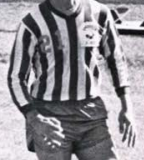

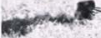

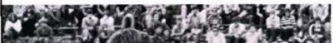

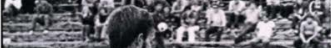
- inderen
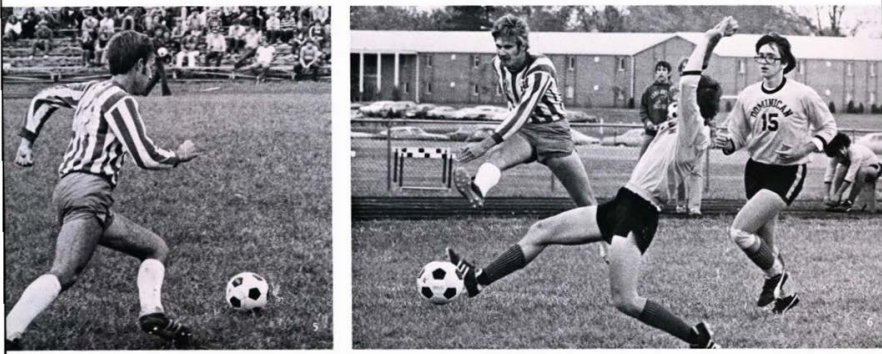


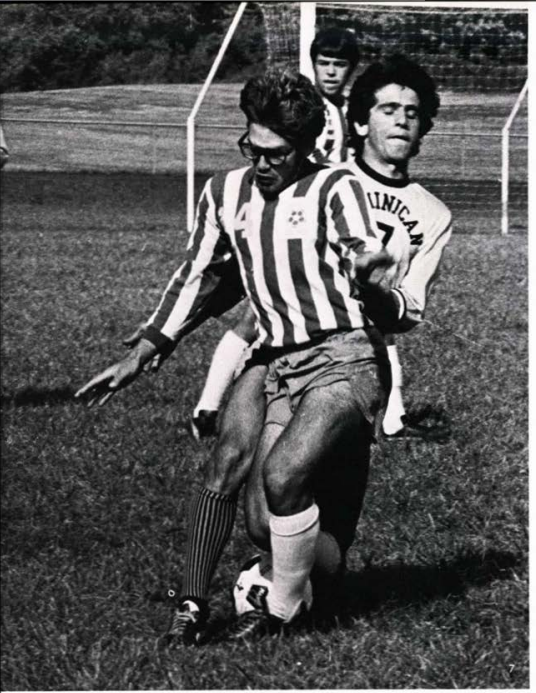

\section{Soccer Team Rebuilds}

The 1977 soccer season is a rebuilding year for Coach McGillivray and the Cedarville College Yellow Jackets. Losing nine seniors from the 1976 squad, the Jackets dropp to a 4-10 overall record. However, their MOC record is 2-1 and their District 22 record is 3-2. Goalie George Mitchell is named the Most Improved Player while Captain Tom Benefiel is named the Most Valuable Player. Benefiel leads the team in goals with twelve and assists with seven. He is named to the All-MOC team along with Tom Aitken, Tom Cook, and John Cavey, Cavey. Benefiel, and Cook also achieve All-NAIA District 22 honors. Benefiel and Cavey are named to the first team of the NCCAA District III. Mark Leach and George Mitchell are given Honorable Mention in the NCCAA District III. Benefiel is given Honorable Mention in the Ohio NCCAA as well as NCCAA AllAmerican honors. The Jackets' record obviously does not tell the whole story. Much progress was made during the season by learning from each game. The 1978 Jackets, with a young team, have an extremely bright future.

1. Tom Benefiel heads the ball away from his opponent.

2. Mike Mignard attempts to gain possession of the ball.

3. Benny Belleman blocks an opponent away from the ball.

4. Mike Mignard sets his sight on the ball going into the goal.

5. Dave Stoner kicks the ball downfield.

6. Tom Benefiel leaps for the ball.

7. Benny Belleman untangles the ball from a Dominican player.

8. Tom Aitken slams a shot on goal. 


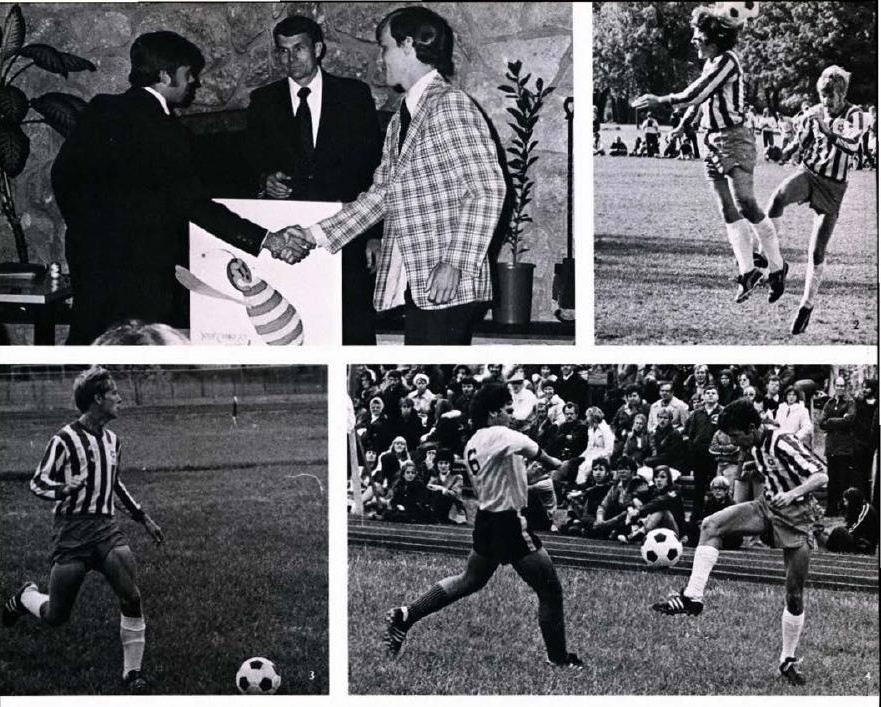



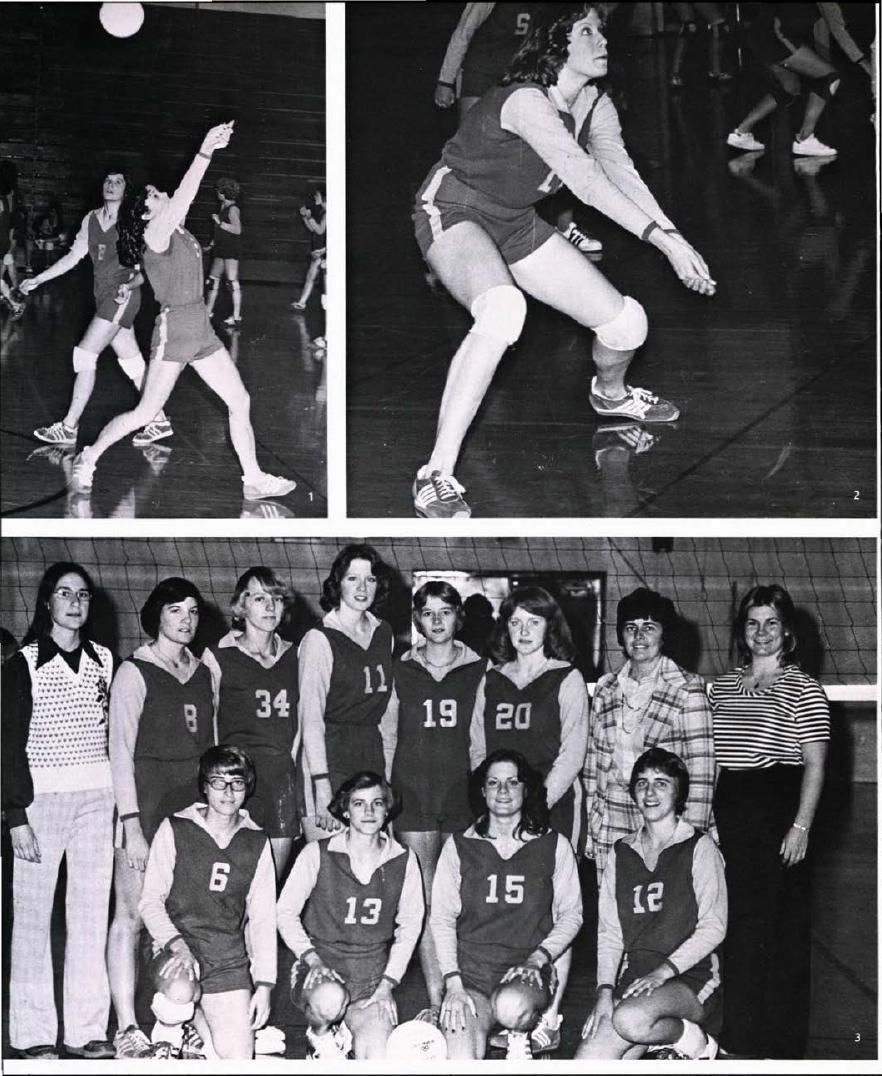


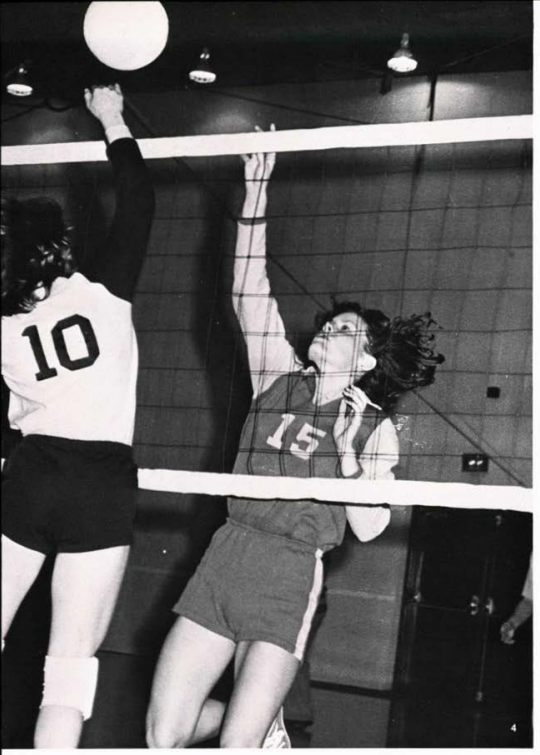

\section{Women Spikers Post 22-19 Record}

The 1977 Women's Volleyball Team posts a 22-19 season record. They finish in the top eight in the state of Ohio. Coach Kearney's squad is enhanced by the consistent playing of Sophomore Brenda Hobar and Senior Captain Judie Cross. Hobar is named MVP and Best Defensive Player while Cross garners honors for the Best Setter. Sue Riegle copped recognition for the Best Serving Percentage and the Most Improved Player is graduating Senior Pat Holmes. The J.V. squad is coached by Jo Priola and they will contribute to the Varsity Netters.

1. Judie Cross sets the ball to Brenda Hobar.

2. Pat Hoimes prepares to set the balt up to her teammates.

3. 1977 Volleyball Team:

FRONT ROW: S. Riegle, V. Totman, Captain J. Cross, R. Norton: BACK ROW: Manager K. Gall, B. Hobar, S. Taylor, P. Holmes, D. Sands, C. Clemons, Coach June Kearney. Manager C. Lancaster. 4. Judie Cross reaches to block a spike. 5. Dorene Sands dives for a set at the knees.

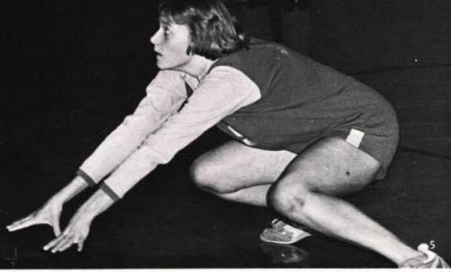


1. Kathy Turner is backed up by Kim Seefried

2. Coach Jo Priola and the bench squad eagerly watch the action. 3. 1977 Junior Varsity Volleyball Team: FRONT ROW: N. Snook, J. Hutchins, C. Heinrich, K. Seefried, R. Raabe: BACK ROW: Coach Jo Priola, L. Penquite, J Griswold, M. Moser, C. Clemons, K.

Turner.

4. Coach Jo Priola gives last minute instructions and strategies.

5. Kathy Turner prepares to set the ball. 6. Landa Penquite puts the ball over the net hoping to score a point.

7. Connie Clemons slams a serve.
Cincinnati Bible

Rio Grande

Wilmington

Ashland

Defiance

Florissant Valley

Eastern Illinois U.

DePauw U.

Central State

Miami U.

Capital

Ashland

Mt. St. Joseph

IUPUI

Indiana Tech.

Eartham College

IUPUI

Indiana Tech.

Bowling Green State

Wright State

Xavier $\mathbf{U}$.

Georgetown U.

Morris Harvey

Morehead State

Rio Grande

Wittenberg

Wittenberg

Ohio Dominican

Sinclair

Lorain

Ohio State

$\mathrm{U}$. of Dayton

Ohio Dominican

Mt. Union

Wooster

Wittenberg

Mt. St. Joseph
$15-9.15-6.15-8$

15-12,15-10

6-15,15-0,15-13

4-15,6-15

7-15.15-17

$10-15,2 \cdot 15$

1-15,6-15

$15-2,9-15,16-14$

15-7.15-8, 15-2

5-15,7-15

$10-15,15-7,15-13$

15-7,4-15, 10-15

8-15,10-15

15-11,15-12

3-15,15-11,12-15

16-14,15-7

15-6,15-7

$10-15,15-11,15-6$

11-15,2-15

15-6.15-10

15-3,17-15

15-5, 15-4

$16-14,15-3$

10-15,5-15

$15-9,7-15,15-10$

15-11,15-7

$8-15,15-6,13-15$

15-12,15-10

15-11,11-15,14-16

15-3,15-1

5-15,15-10,8-15

4-15,11-15

15-6,15-4

15-6,15-10

14-16,1-15

15-12,15-17, 15-1

2-15,8-15
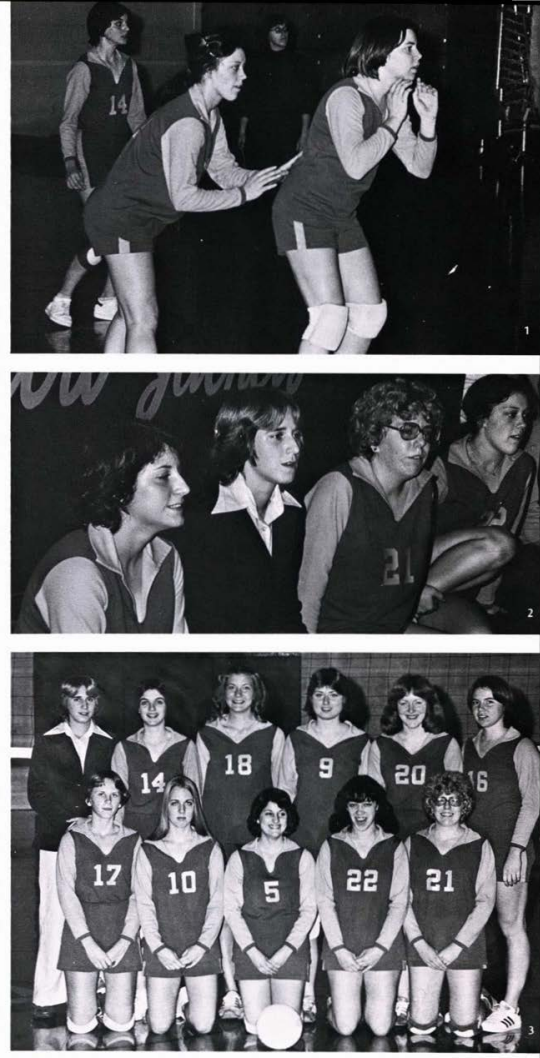


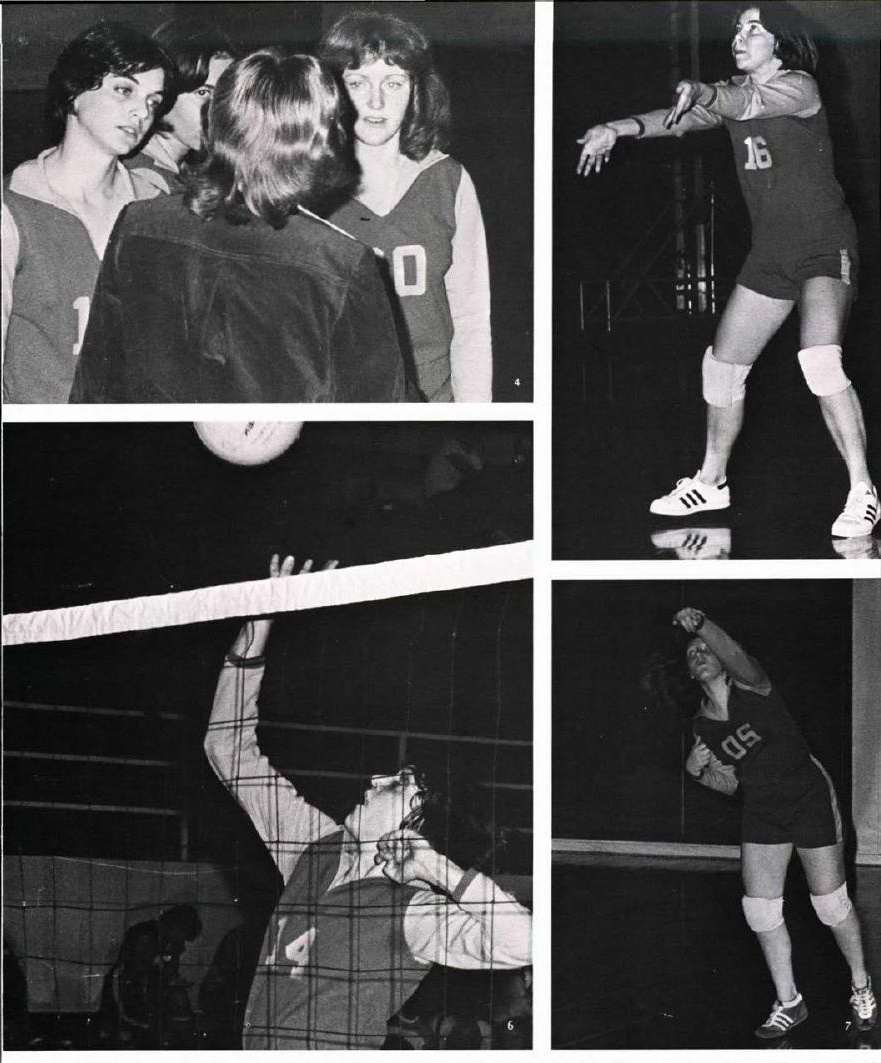




\section{Jackets \\ Post Over-.500 Record}

The Cedarville College basketball Yellow Jackets post a season record that is over the .500 mark. Winning many close games and coming from behind to win proves that the Jackets are more than a 15-14 ball club. The comradery on the 1977-78 squad is impressive and the

team play is refreshing. The team unity is mostly due to the

quiet but strong leadership of Captain Jeff Reep. Reep has visible rapport with his teammates and is a responsible liaison between Coach Don Callan and the players.

1. The 1977-78 VARSITY BASKETBALL TEAM: FRONT ROW: K. Waiters, J. Potter, R. Hickman, M. Allen; BACK ROW: M. Streitmatter, K. Kautman, D. Reep, M. Schwenke, J. Reep, J. Lantz, E. Mounts.

2. Eric Mounts pivots as he looks for an opening to pass the ball.

3. Eric Mounts reaches for a loose ball. 4. Kevin Waters drives to the basket.

5. Captain Jeff Reep fights for sole possession of the ball.

6. Junior Varsity player Scott Carr tries to score against a tight defense.

7. The starting five are introduced prior to the basketball contest.
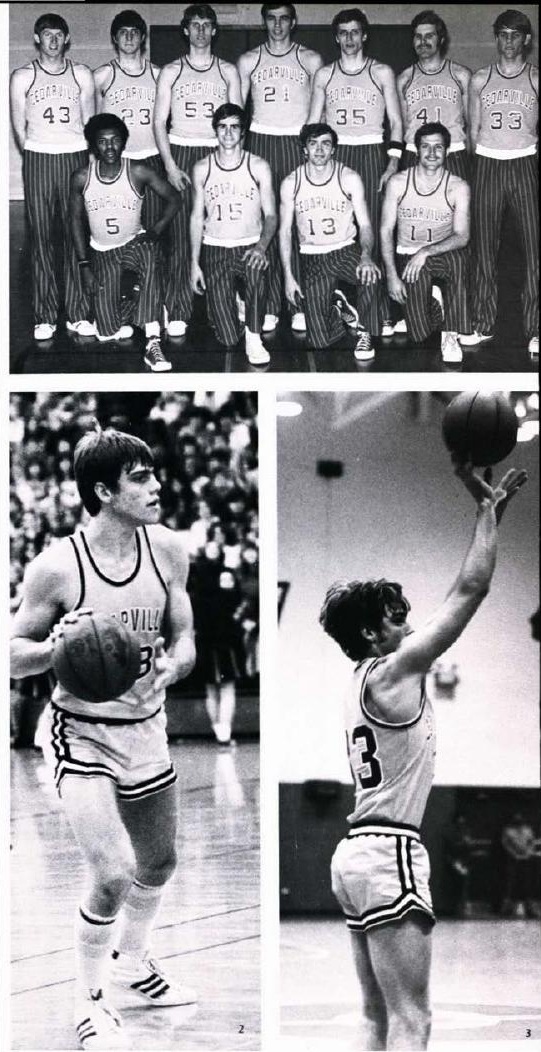
While team play is essential, individuals record playing statistics and honors. Junior Mark Schwenke shoots $55.9 \%$ from the field for the top field goal percentage and grabs an average of 8.9 rebounds per game for top rebound honors.

Schwenke is also the Most Improved Player. The top free

throw percentage is $82.5 \%$ accomplished by Freshman Eric Mounts. Mounts is named to the

All-MOC team and is given Honorable Mention in the NCCAA District III and the NAIA. Senior Captain Jeff Reep garners the top average points per game with 19. Reep is named to the All-MOC, All-

District 22, NCCAA District III, and all-NAIA teams. Jeff Reep is also the Most Valuable Player of the 1977-78 squad. Junior John

Potter is voted the Captain of the 1978-79 Yellow Jackets who look for another winning season of basketball.

1. J.V. starter Ted DeShields puts the ball up for another two points. 2. THE 1977-78 JUNIOR VARSITY BASKETBALL TEAM: FRONT ROW: G. Greve, T. DeShields, W. Gifford, S. Carr: BACK ROW: Coach Bill Potter, T. Lones,

D. Rickard, F. Richer, Manager V. Garcia.

3. Don Rickard waits for a pass from a teammate.

4. Mark Schwenke scrambles for a loose

5. Scott Carr tries to tip the ball in. 6. Scott Carr grabs a rebound.

\begin{tabular}{|c|c|c|c|c|}
\hline 1977.78 MENS VAR & $75 \pi \mathrm{TY}$ BA & ASKETBAL & LSTATST & TICS \\
\hline Wimingtan & 75 & CC & 69 & L \\
\hline Earinarn & 102 & cc & 96 & i \\
\hline $\begin{array}{l}\text { Taylor Tournament } \\
\text { Detroit inst of Tech. }\end{array}$ & 97.70 & $\begin{array}{l}\text { CC } \\
\text { FOAFEIT }\end{array}$ & 70.87 & L. L \\
\hline Malone & 83 & CC. & $\eta$ & $\mathrm{t}$ \\
\hline Mercy Coll of Detroit & 66 & CC & 67 & w \\
\hline Findisy Tourn. & 66. 102 & CC & 65. 74 & L. L \\
\hline Rio Grande. Walsh & 83, 80 & $C C$ & 68,84 & L. $w$ \\
\hline Mercy Coll of Detroit & 71 & CC & 75 & $w$ \\
\hline Mt. Vernon Nazarene & 77 & CC & 88 & $\mathbf{w}$ \\
\hline Ohio Dominican & 61 & $\mathrm{cc}$ & 90 & w \\
\hline Urbana, Malone & 90,89 & CC & 77.96 & L. $w$ \\
\hline Triffin & 93 & $\mathrm{Cc}$ & 69 & $\mathrm{~L}$ \\
\hline Mi. Vernon Nazerene & 91 & CC & 104 & $W$ \\
\hline Urbana, Walsh & 60,79 & CC & 77,80 & w. $w$ \\
\hline Kentucky Christian & 76 & cc & 77 & W \\
\hline Plo Grande & 79 & CC & 82 & W \\
\hline Intfin & 79 & $c c$ & 87 & W \\
\hline Dhio Dominican & 87 & CC & 70 & $t$ \\
\hline $\begin{array}{l}\text { Central State } \\
\text { MOC Tournament }\end{array}$ & 69 & $C C$ & 66 & $\stackrel{L}{L}, L$ \\
\hline
\end{tabular}
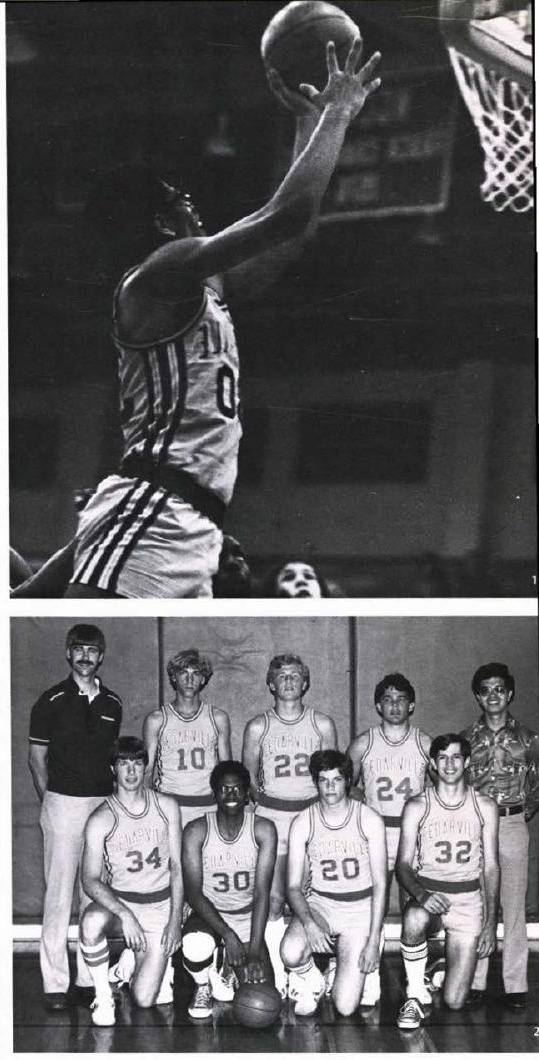

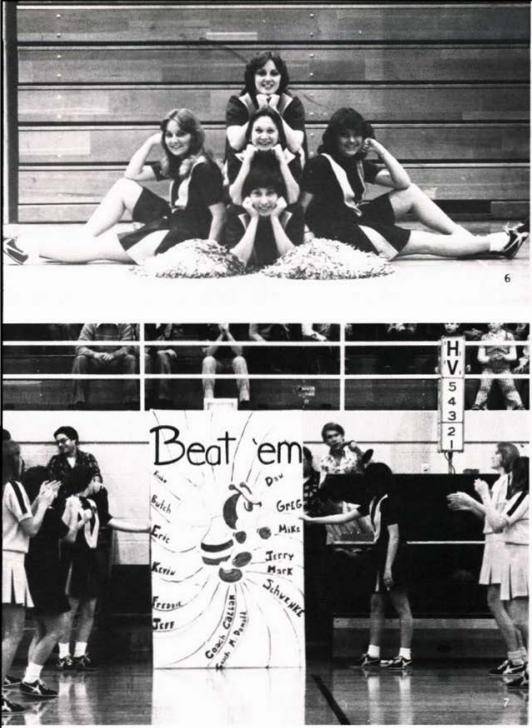

\section{Cheerleaders Spark Enthusiams}

The 1977-78 cheerleading squads are enthusiastic catalysts to the school spirit of soccer and basketball games. When the Jackets are down, the zealots encourage the crowd to cheer their team on to victory. If the Jackets are ahead, the cheerleaders encourage the players to be consistent. These women also have opportunities to share Christ with the cheerleaders of the competing teams.

1. Yellow Jacket mascot Jim Footman charms the crowd.

2. The J.V. Cheerleaders warm the spectators up during a crucial time-out. 3. Amy Young, Kim Smith, and Danette Wetzel show why they need the whitest teeth.

4. Agile Andi MacDermaid does a specialty on the mini-trampoline.

5. Mascot Jim Footman greets a faithful fan.

6. The 1977-78 VARSITY

CHEERLEADERS: FRONT ROW: Rhonda

Young: MIDDLE ROW: Kim Smith, Andi MacDermaid, Danette Wetzel; BACK ROW: Amy Young.

7. The J.V. and Varsity Cheerleaders eagerly await the Jackets' arrival. 8. The 1977-78 JUNIOR VARSITY CHEERLEADERS: Peggy Harrell, Kathy

Krewson, Julie Santen, Valerie Friley. Chariene Jarvis. 


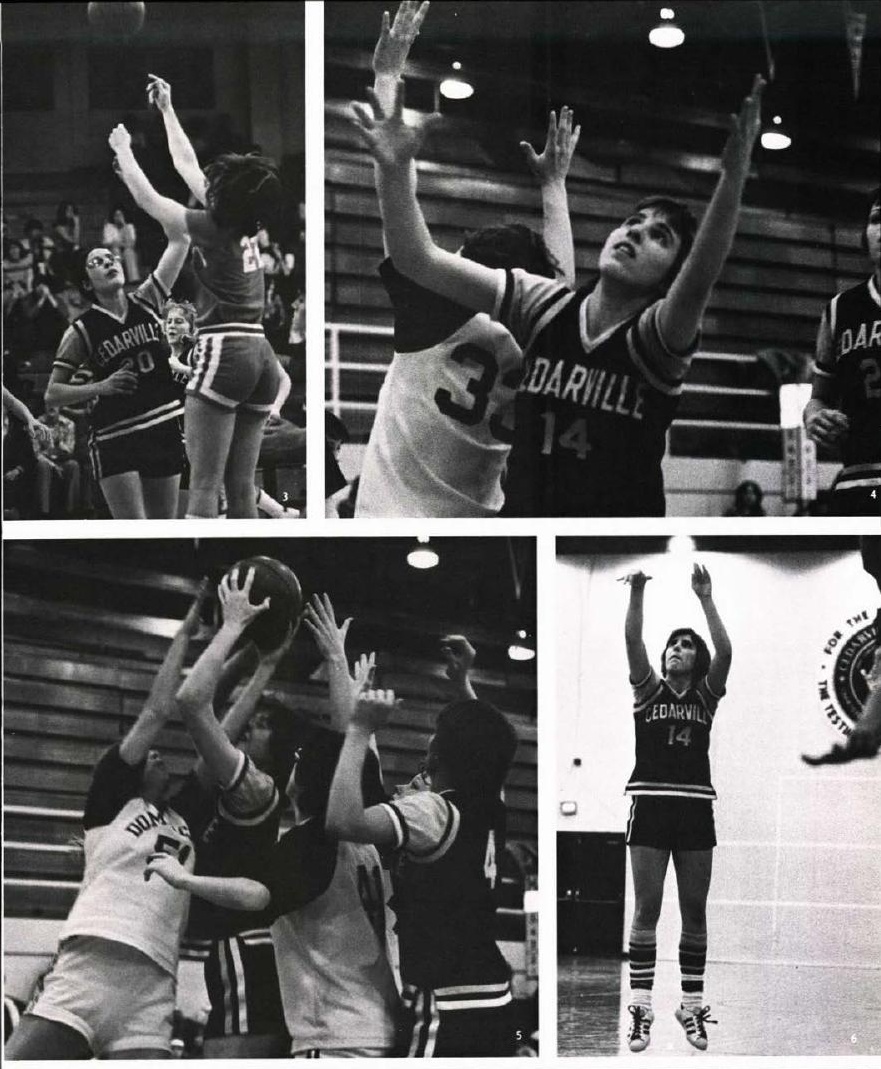


1. Julie Limbaugh attempts to pass the ball over a Dominican opponent.

2. Rachel Norton keeps the ball above her opponents.

3. Julie Limbaugh tries to tip the ball in for a bucket.

4. Vicki Butler balances the ball on the ends of her fingers.

5. Coach Maryalyce Jeremiah encourages her players to play tough defense

6. Kim Gall guards the ball with her life. 7. In a "jump ball" situation, Vicki Butler tips the ball to one of her teammates.

1977-78 WOMEN'S BASKETBALL STATISTICS

Taylor Tournament:

Goshen
Taylor

Taylor
Rio Grande

University of Dayton

Ohio Northern

Capital University

Rio Grande

Wooster College

Wittenberg U.

Wrisht State

Bowling Green U.

University of Akron

Capital University

Ohio Valley League

Wright State

U. of Dayton

Ohio Dominican

Mt. Saint Joseph

Ohio University

Central State U.

Miami University

Ashland College

MAIAW Regional

Mt. Vernon

John Carroll

U. of Dayton

Ohio Northern

\begin{tabular}{|c|c|c|}
\hline $\begin{array}{l}57 \\
71 \\
97 \\
63 \\
31 \\
51 \\
54 \\
44 \\
57 \\
78\end{array}$ & $\begin{array}{l}C C \\
C C \\
C C \\
C C \\
C C \\
C C \\
C C \\
C C \\
C C \\
C C\end{array}$ & $\begin{array}{l}71 \\
60 \\
63 \\
67 \\
78 \\
72 \\
60 \\
82 \\
59 \\
48\end{array}$ \\
\hline 42 & $C C$ & 78 \\
\hline $\begin{array}{l}56 \\
94 \\
43 \\
64 \\
60 \\
54 \\
66 \\
70\end{array}$ & $\begin{array}{l}\mathrm{CC} \\
\mathrm{CC} \\
\mathrm{CC} \\
\mathrm{CC} \\
\mathrm{CC} \\
\mathrm{CC} \\
\mathrm{CC} \\
\mathrm{CC}\end{array}$ & $\begin{array}{l}59 \\
61 \\
72 \\
58 \\
71 \\
66 \\
43 \\
55\end{array}$ \\
\hline $\begin{array}{l}33 \\
56 \\
82 \\
67\end{array}$ & $\begin{array}{l}\mathrm{CC} \\
\mathrm{CC} \\
\mathrm{CC} \\
\mathrm{CC}\end{array}$ & $\begin{array}{l}55 \\
61 \\
57 \\
64\end{array}$ \\
\hline
\end{tabular}

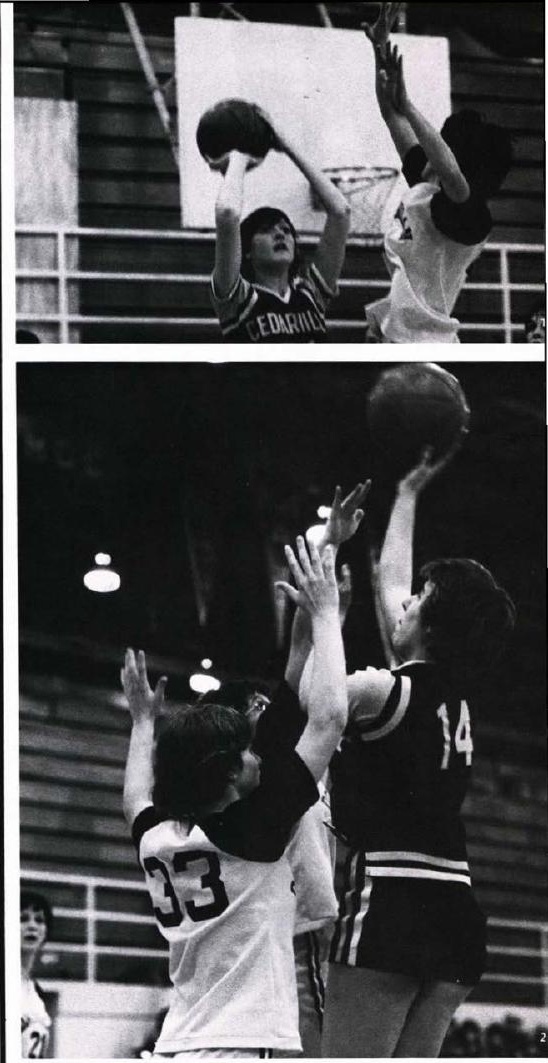




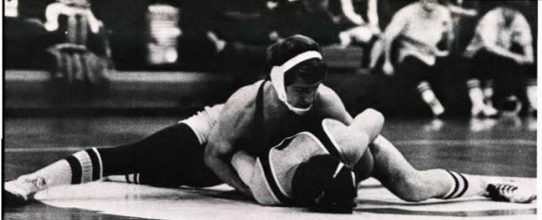

\section{Injuries, Forfeits}

\section{Hamper Grapplers}

The 1977-78 Cedarville College

Wrestling team is severely hampered by injuries and the lack of wrestlers. However, individual performances are the bright spots of the beleagured season. Wrestling honors go to Mark Warren, Jeff Conklin, and Dale West for their individual efforts. Veteran wrestler Don Pippin is lost in mid-season with an elbow dislocation. Despite the lack-luster season Cach Duncan Fields' squad will return intact next season except for graduating senior Tom Williams.

1. Don Pippin uses strategy in preparing for a take-down.

2. The squad observes as the opposing team is introduced

3. Tim Dunn exhibits control over his opponent.

4. Kevin Hathaway prepares to escape the hold of his opponent.

5. Mark Warren and his opponent greet each other before their match.

6. Dale West shows his expertise at gaining control of a match.

7.Mark Hollopeter is determined to bring his opponent down.

8. Tim Dunn waits for the moment of attack. 
1. Tim Dunn tries to force his opponent into the pin position.

2. Wrestling honors go to: SEATED: Dale West: STANDING: Mark Warren, Jeff

Conklin.

3. Mark Warren racks up decision points as he holds control over his opponent.

4. Jeff Conklin uses a leg hold on his opponent.

5. Brent Spradling does not quite see eye to eye with his opponent.

6. Mark Warren urges his opponent to say, "uncle."

7. THE 1977-78 WRESTLING TEAM: FRONT ROW: D. Lord, J. Hunt. D. West. D. Pippin, K. Hathaway, D. Davis; BACK ROW: M Anderson, K. Herwig, J.

Conklin, M. Warren, C. Shuneson, B. Spradling, Coach Duncan Fields.

8. Dale West exhibits his wrestling stance.

ค

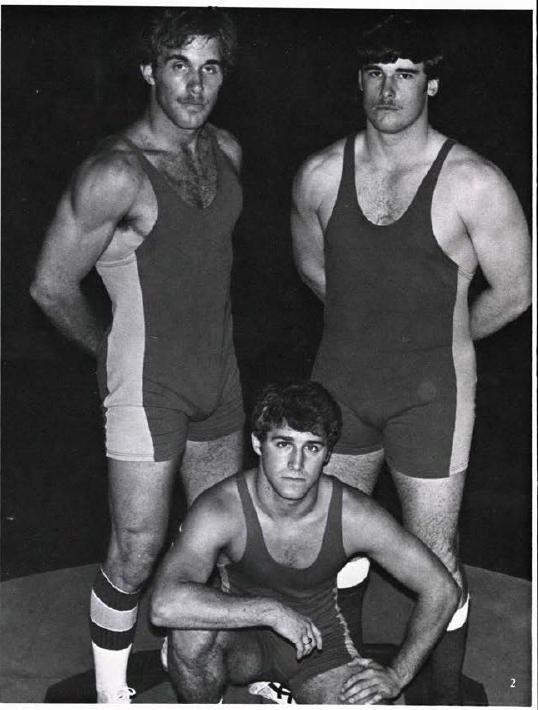


Fred Greetham makes the AllNAIA District 22 team and is voted the Most Valuable Player. Greetham leads the team in batting with a whopping .432 batting average. He also leads the team in doubles with five. triples with two, and homeruns with two. He garners a team high of 20 RBI's, scores 20 runs, steals 17 bases, collects 32 hits, and has a .635 slugging percentage. Over Greetam's three seasons, he has a career batting average of .400 . The Jackets lose one senior. Wes Rowe, to graduation. The 1979 Jackets have a fair shot at the MOC title with most of the team returning next year.

1. Fred Greetham tops nearly all statistical categories and is named to the All-NAIA District \#22 team.

2. Scott Carr waits for an umpire's ruling

3. Fred Greetham exhibits his batting stance.

4. J. Darling and G. Greve wait for a grounder

5. Randy Cagwin fields a grounder. 6. THE 1978 BASEBALL TEAM: FRONT ROW: J. Carroll, R. Meister, D. Merkh, S. Hancock, J. Darling. D. Fullmer, D. Hill,

W. Rowe, B. Baldwin, F. Greetham, D. Lawhead: BACK ROW: D. Stewart. M. Warren, R. Cagwin, M. O'Quinn, G Greve. S. Carr. T. Grovatt. D. Rickard.

\section{BASEBALL STATISTICS}

\begin{tabular}{|c|c|c|c|c|}
\hline Southeastern Bible & 1 & CC & 15 & w \\
\hline Southeastern Bible & 3 & $\mathrm{CC}$ & 7 & w \\
\hline Clearwater Bible & 0 & CC & 20 & w \\
\hline Bap. Bible Coll. of P & 4 & $\mathrm{CC}$ & 11 & W \\
\hline Mt. Vernon Nazarene & 4 & CC & 1 & L \\
\hline Mt. Vernon Nazarene & 12 & CC & 7 & $\mathrm{~L}$ \\
\hline Rio Grande (2) & 4,2 & $\mathrm{CC}$ & 1.5 & L,W \\
\hline Central State (2) & 8 & CC & 6 & L.L \\
\hline Malone (10 innings) & 3 & CC & 4 & w \\
\hline Malone & 4 & $\mathrm{CC}$ & 6 & W \\
\hline Walsh & 3 & $\mathrm{CC}$ & 9 & W \\
\hline Walsh & 3 & $\mathrm{CC}$ & 13 & w \\
\hline Ohio Dominican & 2 & $\mathrm{CC}$ & 3 & w \\
\hline Ohio Dominican & 10 & $\mathrm{CC}$ & 5 & L \\
\hline Urbana & 4 & CC & 5 & w \\
\hline Urbana & 1 & CC & 8 & w \\
\hline University of Dayton & 3 & CC & 1 & $\mathrm{~L}$ \\
\hline University of Dayton & 5 & CC & 1 & $\mathrm{~L}$ \\
\hline Tiffin & FORFEIT & & $v$ & \\
\hline Tiffin & FORFEIT & & 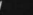 & \\
\hline NAIA Playoffs & & & & \\
\hline Wilmington & 2 & CC & 3 & W \\
\hline Malone & 8 & CC & 2 & $\mathrm{~L}$ \\
\hline Central State & 10 & CC & 7 & L \\
\hline John Wesley & 8 & CC & 4 & L \\
\hline
\end{tabular}
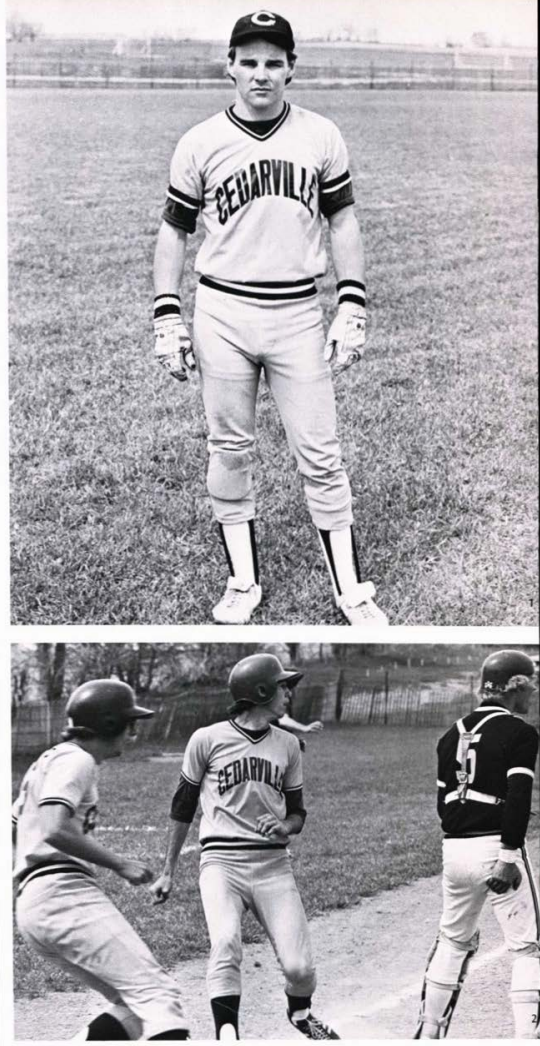


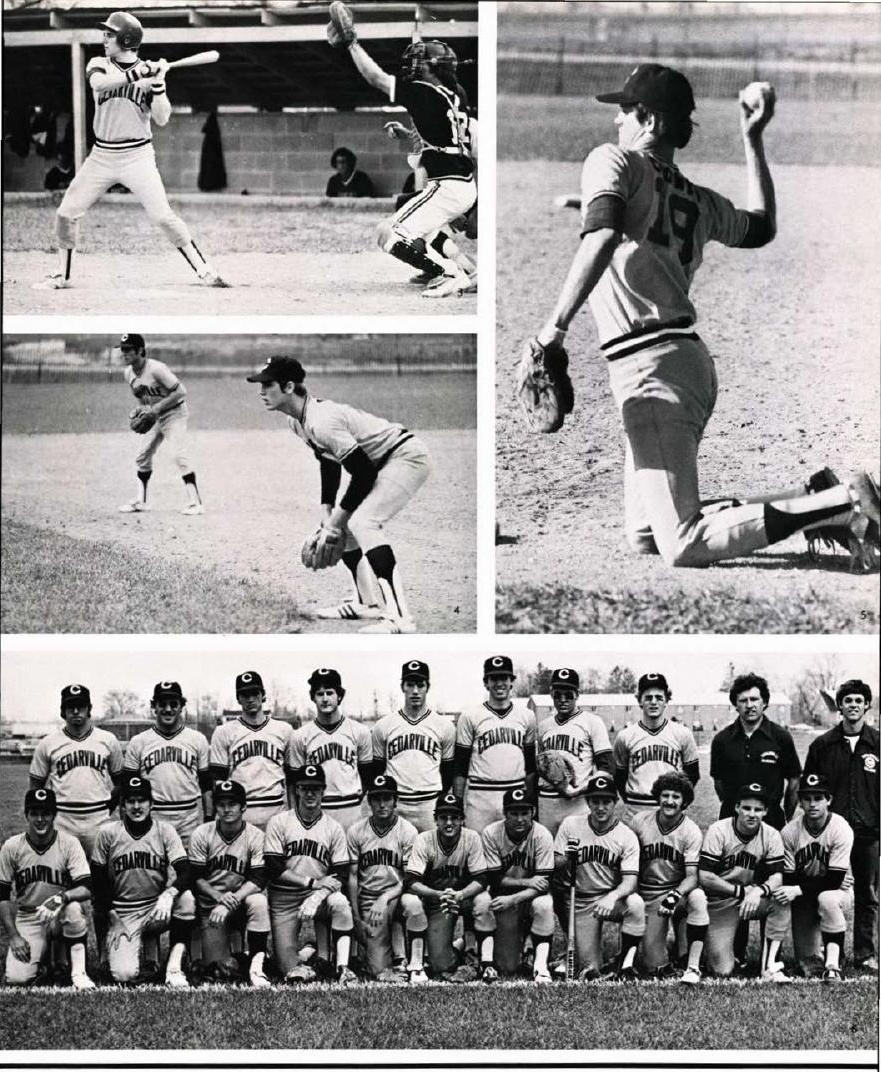




\section{Jackettes Finish In State's Top Eight}

The Cedarville College women's softball team posts a final season tally of $17-8$. Over the three-year existence of

Cedarville's softball program. the Jackettes have a respectable cumulative record of 32-15. The hard-hitting softballers finish in the top eight teams in the state tournament. The success of Kearney's squad is due to strong team play and individual playing statistics. Kim Hill and Vicki Butler are named Defensive Players of the Year. Sue Kulp cops the awards for RBI leader, Batting leader. home-run leader, and Most

Valuable Player. Kulp sets an outstanding record of $65 \mathrm{RBI}$ 's, slugs out an unbelievable .615 batting average, and pounds ten home-runs. The team loses only two seniors, Kim Gall and Kathy

Green. Kearney has a young team and expects to improve on their 32-15 cumulative record next year.

1. Connie Clemons takes a slim lead off base.

2. Anna Phillips concentrates on making contact with the ball.

3. Kathy Green takes her base. 4. Brenda Hobar sincerely hopes that the ball is in her glove.

5. Susan Riegle exhibits her wide batting 6. Vicki Butler is kept close to the base.
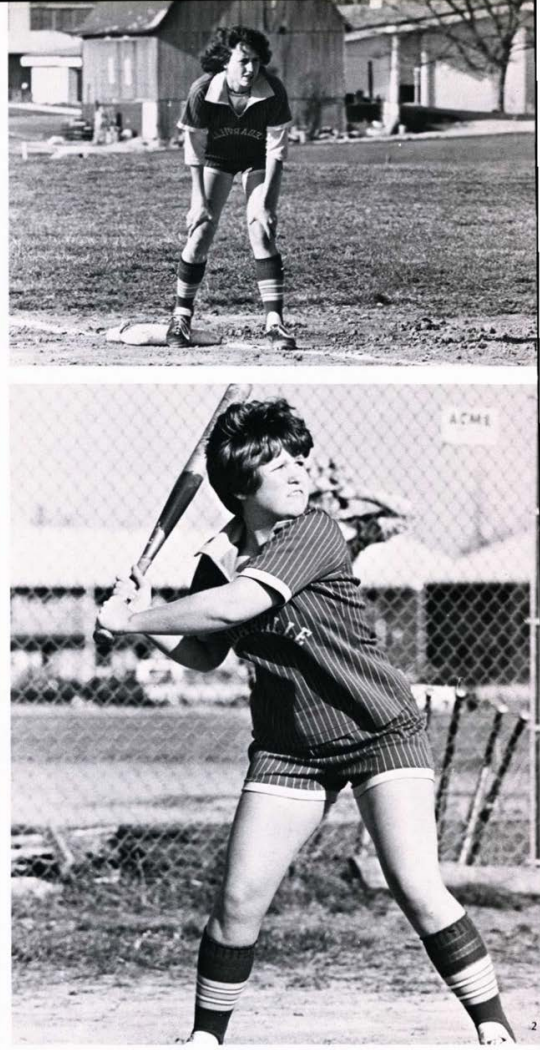


\section{Trackmen Take Second In NCCAA}

The Cedarville College trackmen place second in the NCAA national meet held in Cedarville. Fifteen teams compete and only Northwestern of Minnesota outlasts the Jackets. In the MidOhio Conference play-offs, the thinclads place fourth as Dave Rogers sets a school record by heaving the shot-put 49', three inches for a second place finish.

Brian Hull is the only winner.

placing first in the mile run.

Observing the season as a whole, Hull sets a school record in the 10,000 meter run, clocking in at 30:09.1. Polevaulter Mark Peters jumps for a school record of fourteen feet, five inches. Dave Rogers heaves the discus for $150^{\circ}$, six inches, also a school record.

1. Ken Gaines rounds the curve of the 2. Mark Peters clears the bar. 3. Jim Spurrier stretches to clear the hurdle.

4. Dave Rogers wonders how far he threw the shop-put.

5. Mark Peters practices his polevaulting technique.

6. Brian Hull and Bruce Henslin giance at the score sheets.

7. THE 1978 TRACK TEAM: FIRST ROW: $J$. Lenington, K. Howard, T. Lones, $D$, Shaw, R. Hickman, T. Ruiz, Coach Elvin King: SECOND ROW: D. Heffernan, J. Payne, S. Murphy, P. Said, C. Clark, K.

Gaines, C. Walker, Coach John McGillivray; THIRD ROW: Coach Russ Clark, D. Rogers, R. Crist, B. Wittlinger. B. Henslin, B. Hull, T. Yater, M. Streitmatter, J. Spurrier, W. Gifford, D. Treese.

8. Tom Hutchinson attempts to gain on his leg of the relay.

\section{TRACK STATISTICS}

Earlham Relays Cedarville Relays NCCAA Nationals Depauw Invitational Mid-Ohio Conference NAIA District \#22
Second

Second

Second

Eleventh

Fourth

Fifth 

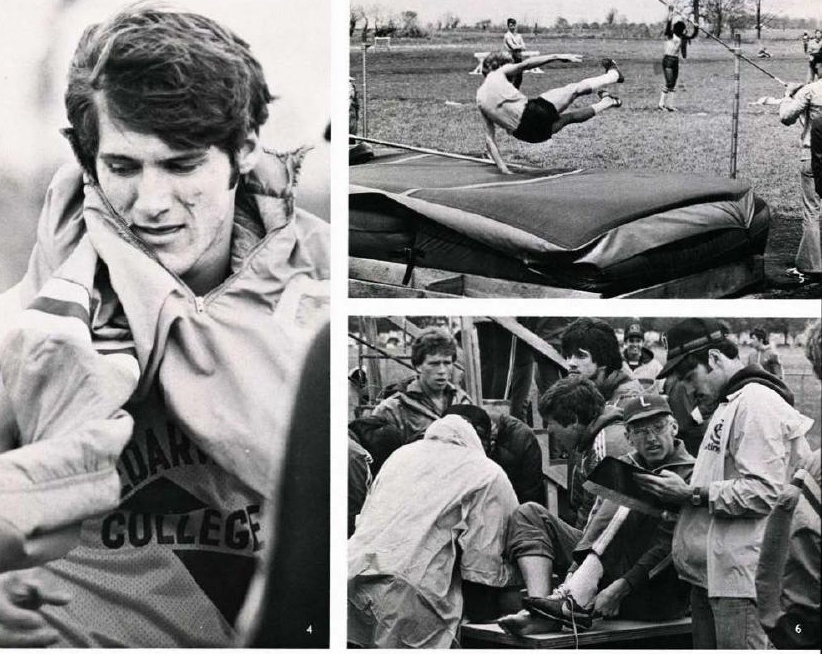

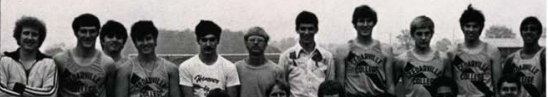
s

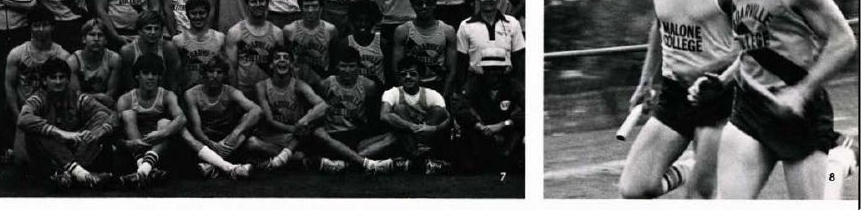



1. THE 1978 WOMEN'S TENNIS TEAM: FRONT ROW: L. Paimer, P. Harding, $K$. Hermansky. A. Ross, B. Trittipoe Manager M. Chipukits, C. Samuelsen, L. Penquite, S. Taylor, D. Billings, J. Hansen; BACK ROW: Manager R. Scott.

C. Napier, K. Steinhofer, J. Decker, D. Tillson, Coach Pamela Diehi.

2. Patti Harding takes a break from a thorough practice session.

3. Doubles team Shawn Taylor and Landa Penquite anticipate service from the opposing team. 4. Amy Ross serves as Becky Trittipoe waits for the return in a doubles match.

5. Amy Ross carefully plans her next

stroke.

6. Number three singles' player Laura Palmer sinks her teeth into a refreshing orange.

7. Becky Trittipoe exhibits her followthrough form after a forehand stroke.

\section{WOMEN'S TENNIS STATISTICS}

\section{Bluffton}

Wright State

Kent State

Central State

Ohio Nothern

Toledo $\mathrm{U}$.

Findlay College

Central State

Capital U. (forfeit

Wright State

Otterbein College

$\begin{array}{llll}4 & C C & 5 & W \\ 9 & C C & 0 & L \\ 9 & C C & 0 & L \\ 0 & C C & 0 & W \\ 5 & C C & 4 & L \\ 8 & C C & 1 & L \\ 0 & C C & 9 & W \\ 3 & C C & 6 & W \\ 0 & C C & 9 & W \\ 7 & C C & 2 & L \\ 9 & C C & 0 & L\end{array}$




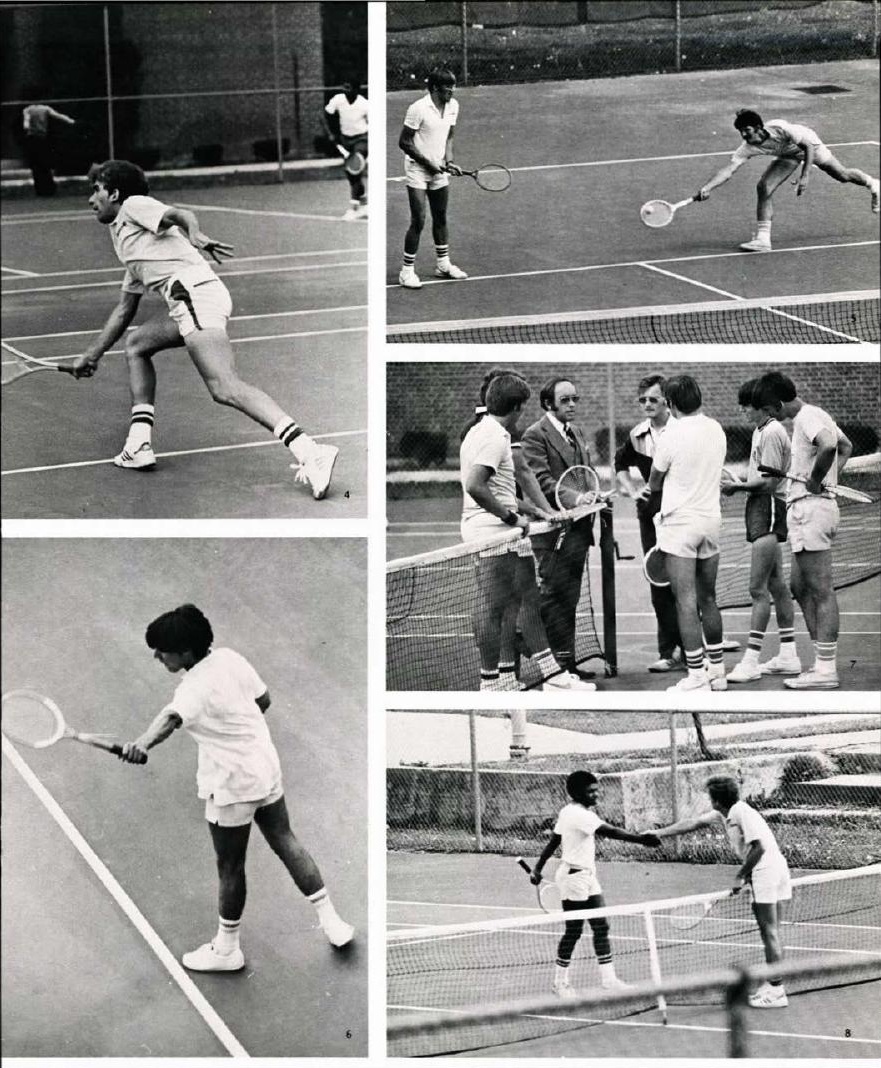



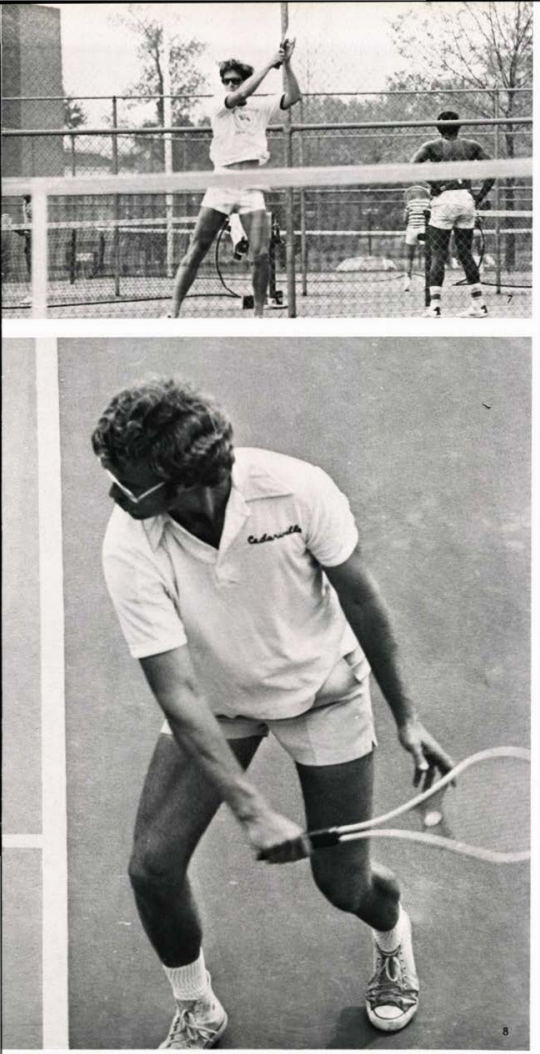

Dr. J. Murray Murdoch is a

Professor of History and the Chairman of the Social Science Department. He is now in his thirteenth year of coaching and has compiled an overall record of 201 wins and just 22 losses as of May 2, 1978. Murdoch has led Cedarville to ten MOC and nine District \#22 championships and his teams have been represented for 11 consecutive years at the NAIA National Tourney in Kansas City.

1. David Bergandine prepares to contact the ball with a backhand stroke.

2. Dave Lynch puts his entire body into a serve.

3. Ken Erny and Dave Bergandine exchange smiles that can only mean victory.

4. Gary Gallian returns with an overhead smash.

5. Ken Erny's consistent serving always makes him a threat to the opponent. 6. THE 1978 MEN'S TENNIS TEAM: FRONT ROW: P. Walter, L. Randall, R Medlock, D. Green, C. Colas, B. Medlock; MIDDLE ROW: C. Weaver, C Fisher, D. Bergandine, R. Michel, T. Dowd, S. Stairs, S. Lewis; BACK ROW: Coach Murray Murdoch, D. Murphy, D Lynch, S. Swayze, J. Poole, B. Fleming. K. Erny, Gary Gallian.

7. Gary Gallian prepares to execute his two-handed backhand.

8. Steve Stairs awaits his opponent's return.

1978 MEN'S TENNIS STATISTICS

$\begin{array}{lllll}\text { Thomas More } & 0 & \text { CC } & 9 & \text { W } \\ \text { Spring Arbor } & 8 & \text { CC } & 1 & \text { L } \\ \text { Walsh } & 2 & \text { CC } & 7 & \text { W } \\ \text { Rio Grande } & 0 & \text { CC } & 9 & \text { W } \\ \text { Malone } & 3 & \text { CC } & 6 & \text { W } \\ \text { Hillsdale } & 8 & \text { CC } & 1 & \text { L } \\ \text { Spring Arbor } & 4 & \text { CC } & 5 & \text { W } \\ \text { Tri-State } & 2 & \text { CC } & 7 & \text { W } \\ \text { Wilmington } & 0 & \text { CC } & 9 & \text { W } \\ \text { Mt. Vernon } & 0 & \text { CC } & 9 & \text { W } \\ \text { Ashland } & 3 & \text { CC } & 6 & \text { W } \\ \text { Thomas More } & 0 & \text { CC } & 9 & \text { W } \\ \text { Mt. Vernon } & 2 & \text { CC } & 7 & \text { W } \\ \text { Wilmington } & 1 & \text { CC } & 8 & \text { W } \\ \text { Wittenberg } & 7 & \text { CC } & 2 & \text { L } \\ \text { Central State } & 0 & \text { CC } & 9 & \text { W } \\ \text { Forfeit } & 0 & \text { CC } & 9 & \text { W } \\ \text { Forfeit } & 0 & \text { CC } & 9 & \text { W } \\ \text { Cedarville Invitational } & & & & \\ \text { Cedarville } & & & & 43 \\ \text { Bap. Bible Coll. } & & & & 26 \\ \text { Transylvania } & & & & \text { 16 } \\ \text { Central State } & & & & 13\end{array}$

Mid-Ohio Conference

Cedarville

Walsh

Malone

Rio Grande

Mt. Vernon 


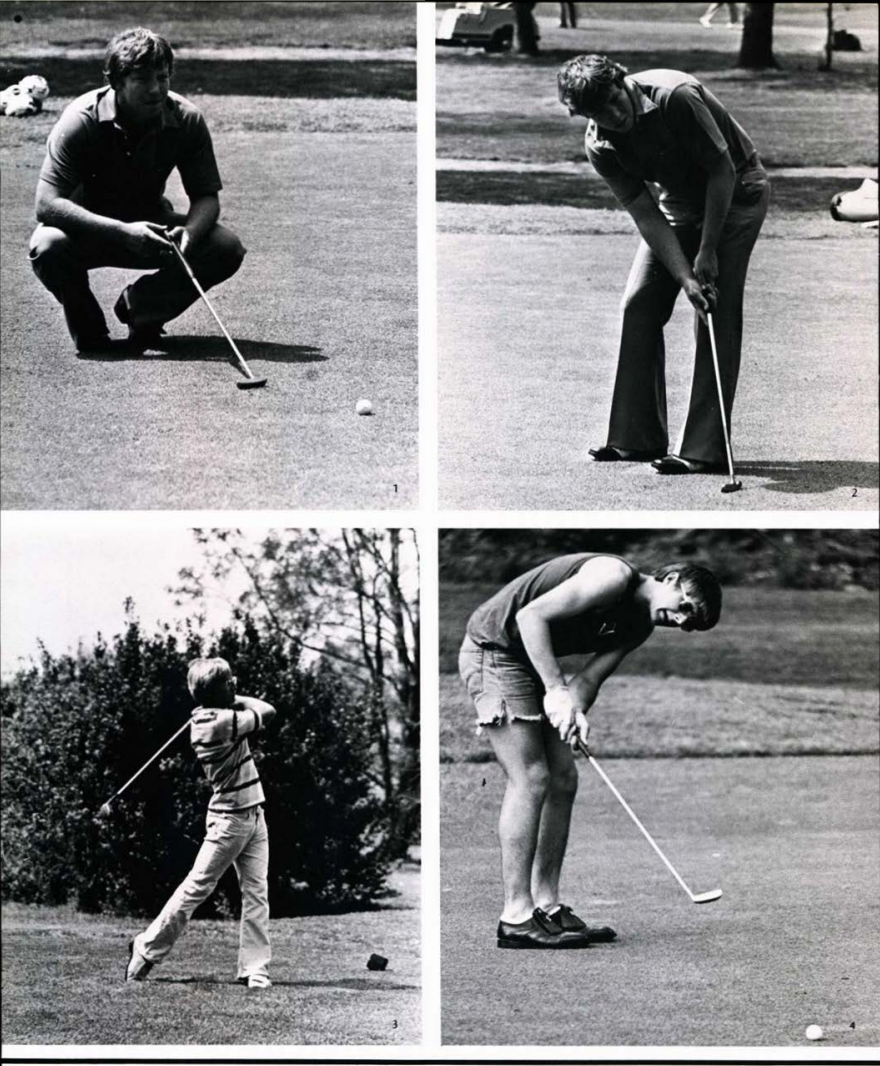




\section{Miracle Depicts Types Of Interaction}

The 1978 MIRACLE is a compilation of pictures, artwork. and copy that seek to convey the concept of interaction. This interaction, as visualized in this book, can take many different forms. God has created us to have fellowship with each other.

It is through this human interaction that we can know God in a greater cognitive way. Genesis 1:28: "And God blessed them; and God said to them, Be fruitful and multiply, and fill the earth, and subdue it; and rule over the fish of the sea and over the birds of the sky, and over every living thing that moves on the earth." This yearbook does not seek to raise anyone up except the sovereign

God of the universe. He alone deserves the credit for the completion of this visual memory of the $1977-78$ school year.

1. 1978 MIRACLE STAFF: K. Amstutz, Charles Miller, Marlin Rayburn, R. Scott, J. Teckmeyer, J. Zachary, D. Rapinchuk, P. Arvay, N. Tillman, M. Filmer, L. Randall, K. Price.

2. Jan Techmeyer, Rachel Scott, and Paula Arvay display their expertise in the Underclassmen section.

3. Charlie Miller gives Kent Amstutz advice on how to make a yearbook budget go a long way.

4. J. Zachary and D. Rapinchuk become nostalgic over old annuals.

5. The Activities section is ably handled by S. Roth, C. Coates, and D. Dubke. 6. The staff editorially criticizes an old yearbook.

7. Charlie Miller is willing to help the staff with any deadline difficulties.
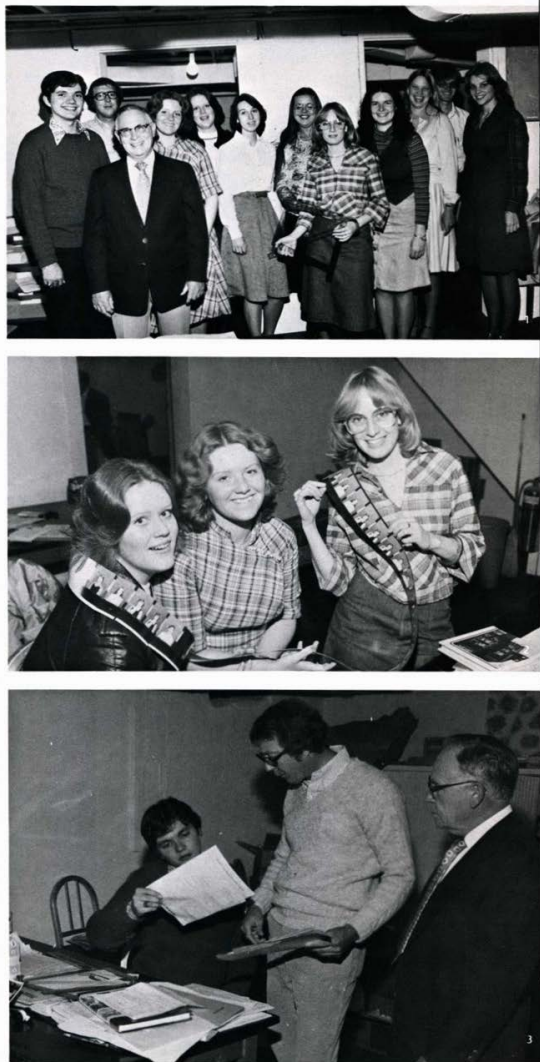


\section{MIRACLE STAFF}

Editor-in-Chief

Assistant Editor

Activities Editor

Assistant Activities Editor

Assistant Activities Editor

Advertising Editor

Business Editor

Faculty Editor

Faculty Editor

Literary Editor

Literary Contributor

Literary Contributor

Senior Editor

Assistant Senior Editor

Sports Editor

Sports Photographer

Underclassmen Editor

Underclassmen Editor

Assistant Underclassmen Editor

Assistant Underclassmen Editor

Photography Editor

Photographer

Photographer

Photographer

Photographer

Photographer

Photographer

Photographer

Photographer

Photographer

Photographer

Typist

Typist

Index Editor and Typist

Josten's American Representative

Advisor

- SPECIAL THANKS goes to Roy Ke and New Life Media Studios (Stan Seevron Youngman,

and New Life Media Studios (Stan Seevers, Ty Bryant,
Barb Beikert, Del Mohler, and Steve Keller) for their services.
Kent Amstutz

Paula Kozma

Donna Dubke

Cheryl Coates

Sandi Roth

Karen Price

Debbie Clough

Jan Zachary

Debbie Rapinchuk

Kent Amstutz

Nanci Tillman

Ginny Decker

Becky Street

Margie Filmer Lee Randall

Jim Barrett

Rachel Scott

Janet Teckmeyer

Gladys Krause

Paula Arvay

John Dannenberg Amy Ross

Debbie Love

Marnie Vail

Lester Hicks

Ed Smith

Mike Nelson

Greg Wickham

Don Moses

Cal Swank

Mark McDougal

Beth Beikert

Nancy Amstutz

Lynn Rohm

Mr. Charles Miller

Mr. Marlin Rayburn

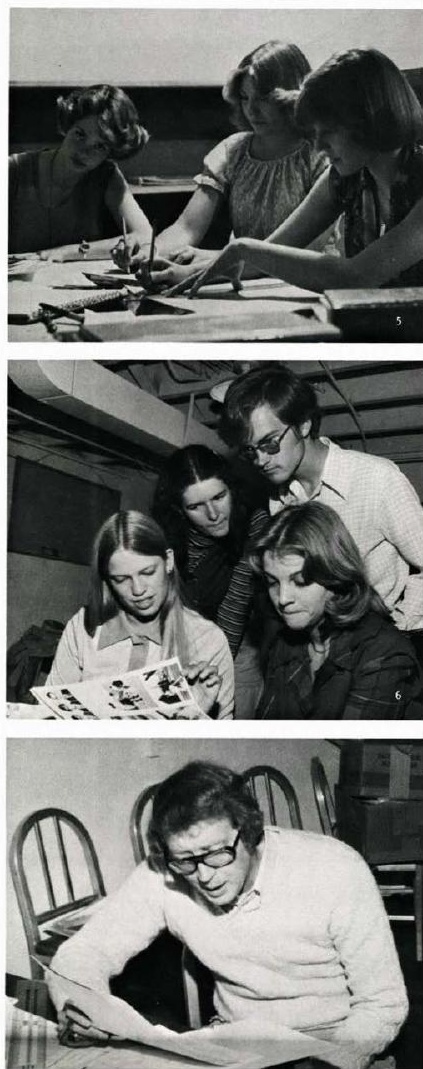




\section{Swordbearers Have Diverse
Ministries}

The 1977-78 Swordbearers continue their diverse ministries that center around the local church. There are four core

gospel teams, each with a student team leader. Music

Coordinator Kathy Howell practices with the four teams combined and then each team schedules separate practices with their team leader. The core team travels on weekends to churches who request their ministry. The ministry includes puppets, seminars, Sunday School lessons, music, Bible teaching and preaching, and youth rallies. The Swordbearers also minister in the homes that extend their hospitality to them.

1. FRONT ROW: S. Miller, D. Parvin, T. Tangblade, K. Angel, T. Hutchison; BACK ROW: M. Horne, C. Wicks, R. Michel, K. Faull, S. Wilson, J. Decker, D. Kelso, D. Ormsbee (team leader), K. Henderson.

2. FIRST ROW: T. Hoganson, L. Kuschel. K. Wilhite: SECOND ROW: P. Van der Hoeven, D. Repp, J. Leeke, G. Stone: THIRD ROW: D. Jansen, B. Henslin, D. Storch; FOURTH ROW: M. Bentley (team leader), B. Whitaker.

3. FIRST ROW: D. Kirk, R. Strobridge, J. Callan; SECOND ROW: M. Staples, K. Waites, K. Seymour. B. Abernathy (team leader): THIRD ROW: S. Towle, J. Riter. S. Levin; FOURTH ROW: C. Prokop, K. Browne, C. Hickey.

4. FIRST ROW: K. Williams, C. Staller, J Maitland; SECOND ROW: D. Tyler, D. Blackburn; THIRD ROW: R. Smith, D. Messenger, C. Miller; FOURTH ROW: $K$. Payne, M. Rae: FIFTH ROW: M. Lones, M. Culfman (team leader), B. Hayes.
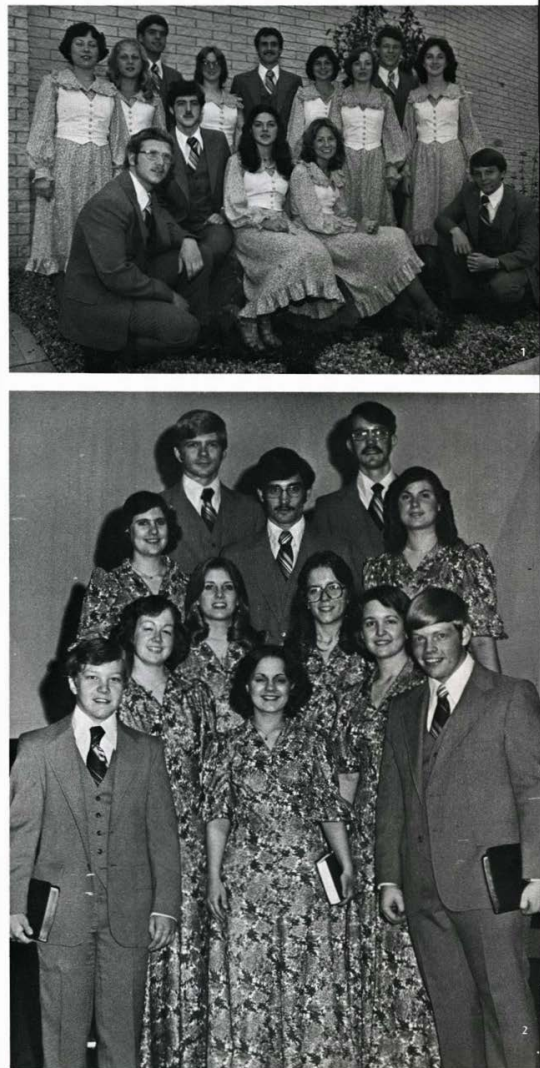

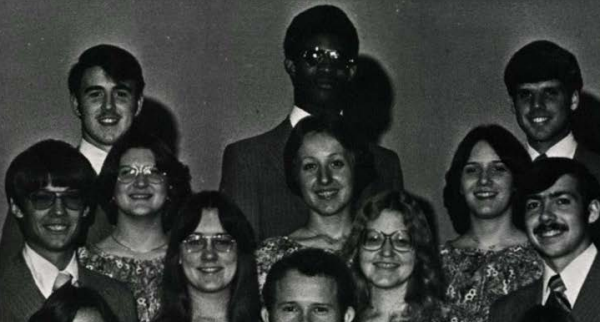

(6) 60 in

s.

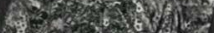

4:
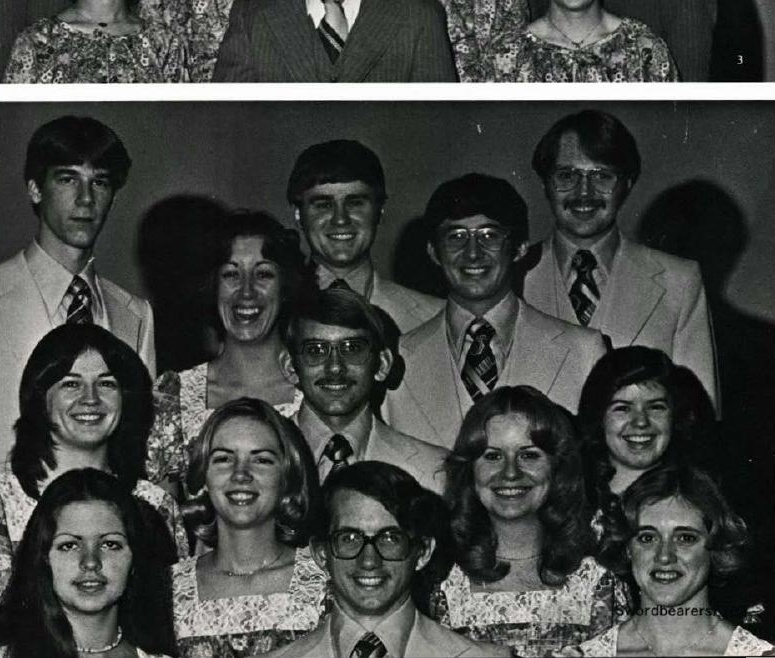


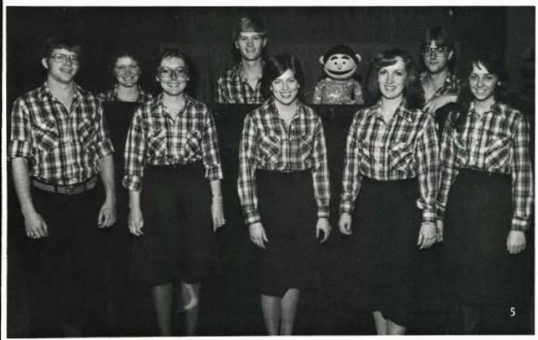

\section{Swordbearers} Plant Churches; Master's

\section{Muppets Reach Children}

Their are two extensions teams that work with young churches. One team is specifically planting a church in the South Charleston, Ohio area. A fall youth conference is held annually on the first weekend in November. Two core teams travel during the spring break and a team travels for eleven weeks during the summer. The outreach ministries of the Swordbearers are many and give students valuable experience for their future service.

The Master's Muppets continue their successful ministry to children. The teams travel to churches and schools to present God's Word through the medium of puppetry.

1. SWORDBEARERS' EXTENSION TEAM: C. Spicer, J. Erikson, C. Wicks, B. Lanphier.

2. Marilyn Horne conducts an informative seminar.

3. SWORDBEARERS' EXTENSION TEAM: FIRST ROW: R. Bigelow, B. Sparks:

SECOND ROW: T. Anderson, P. Edwards. T. Davis, S. Stange; THIRD ROW: T.

Stoner.

4. SWORDBEARERS' EXECUTIVE

COMMITTEE: K. Howell, Pastor Harold Green, D. Ormsbee, D. Lyons, S. Levin. B. Abernathy, M. Cuffman

5. MASTER'S MUPPETS: FRONT ROW:

N. MacKenzie, B. James, J. Davis, L. LaHaye, P. Mills; BACK ROW: J. Wright. K. Masters, Bill Carroll (team leader). 6. MASTER'S MUPPETS: D. Wellinghott,

D. Christian (team leader), C. Coulson. 7. MASTER'S MUPPETS: FRONT ROW: T. Redmond, J. Rosenau; BACK ROW: $K$. Brower, B. Neally, M. Howard. 
$2+8$

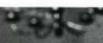

a.

Th N1VK

Irana

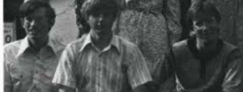

$\operatorname{sel}($ By $)$

At
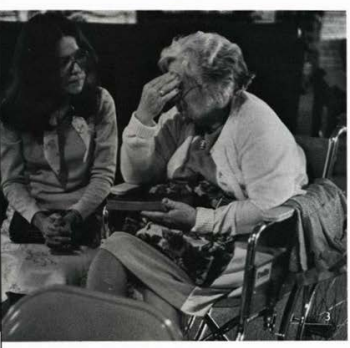
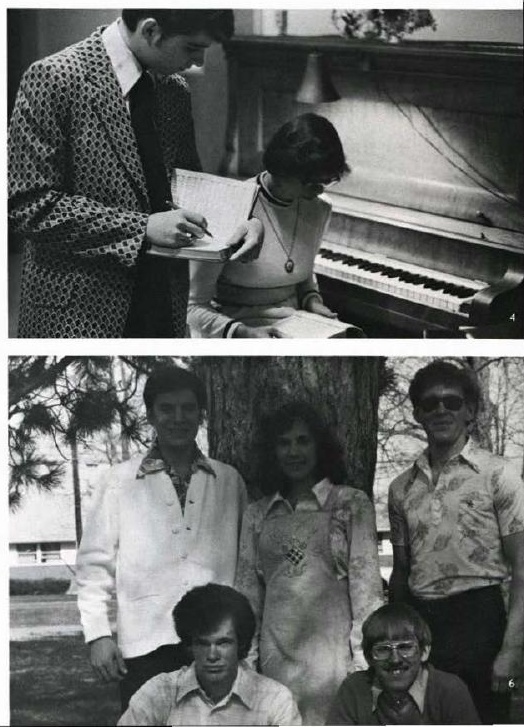

$35,28=$ कै

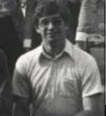

68 
1. HOSPITALITY WEST: D. Denny (team leader), S. Arthur, D. Schieber, C. Lofgren, R. Martin, C. Denny. L. Sharp,

C. Ryalls

2. INDEPENDENT ORDER OF ODD

FELLOWS: FRONT ROW: L. Stauffer, R

Haselip, B. Street; BACK ROW: D. Rowe.

D. Spencer.

3. KNIGHTS OF PYTHIAS: FRONT ROW:

N. Longnecker, D. Woodall, B. Miller; BACK ROW: B. Driscoll, A. Fava, L.

Eissens, J. Teckmeyer, M. 3. Greenwood Manor Team Leader Dave Drozek meets with his team for prayer before going to the geriatric center.

4. Rhonda Hettinger greets a cheerul senior citizen. 5. THE BLESSED HOPE SINGERS: FRONT ROW: T. Filler, D. Woodall, M. Highman, R. King: BACK ROW: J. Ebel.

T. Galbreath, K. Jackson, D. Wiggin, C. Jarvis.

6. After a short worship service, Randy Pope participates in personal interaction by sharing verses of Scripture with a geriatric patient.

7. Building friendships is one of the important aspects of the geriatric ministry.
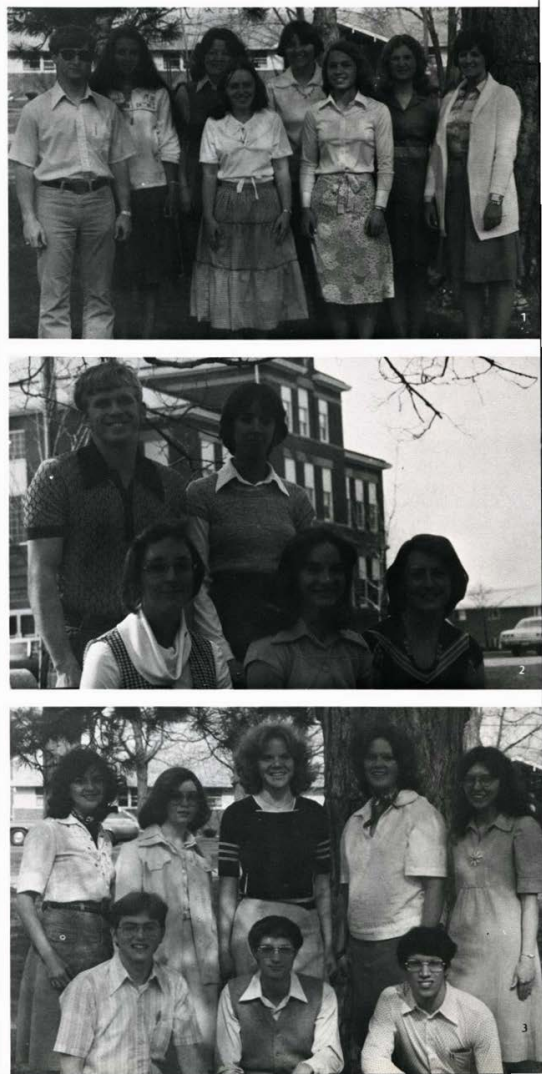

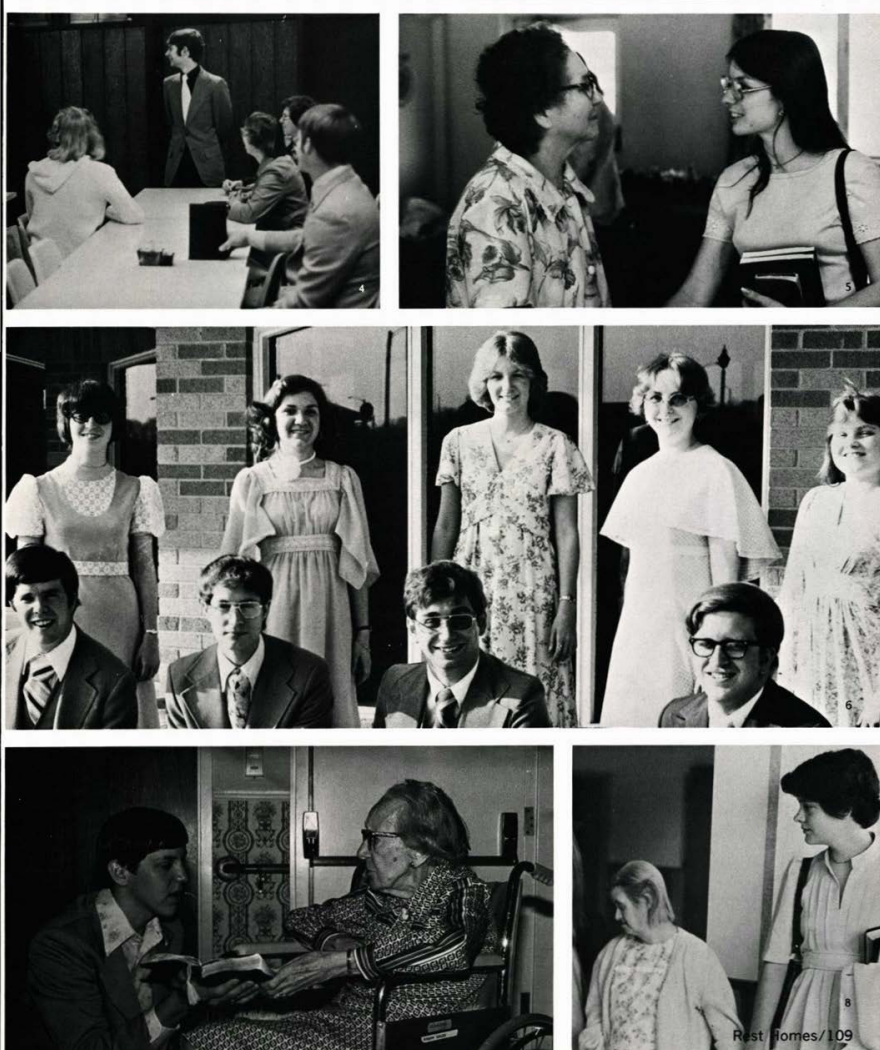


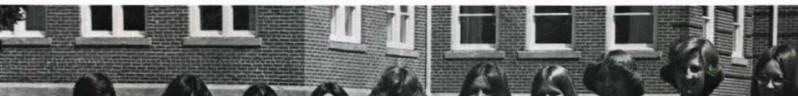

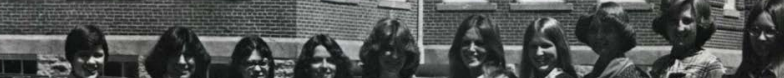

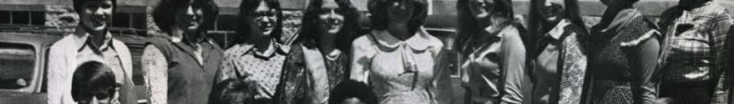
-7)

and

( 13

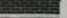
1 1 4 की

singest

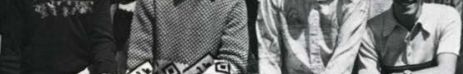

18.

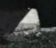

25.
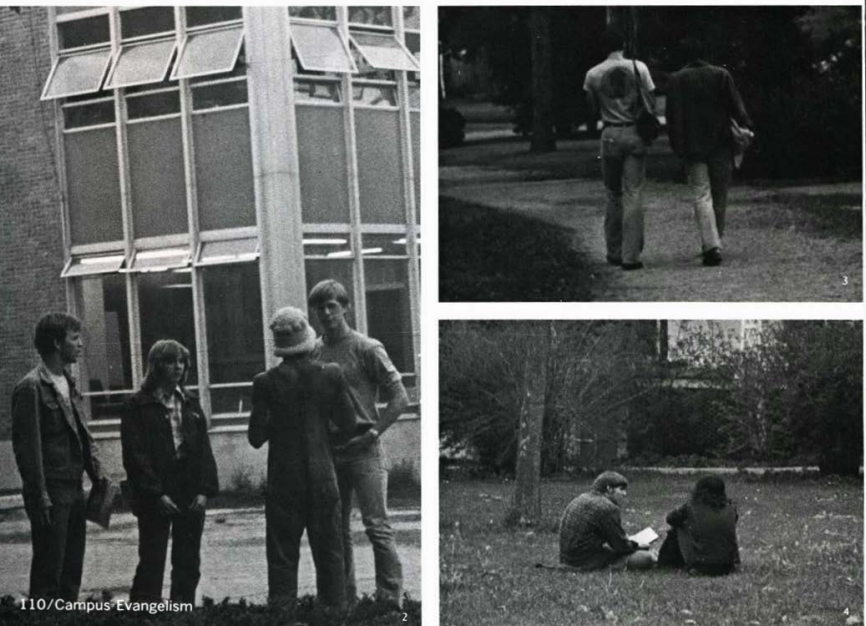

에에

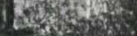

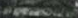

ras? 


\section{Students Articulate God's Words}

The Bethesda Rehabilitation Center is a domicile for juvenile offenders. Cedarville college

students witness to these teenagers by living a consistent Christian life in front of them, and by just being a friend to them.

The Springfield and Dayton Detention Homes are also domiciles for juvenile offenders.

Cedarville students try to be involved with the youths in various social and athletic activities. During this time, Cedarville students can show God's love in action.

The Cincinnati Rescue Mission is a place where few Christians visit. Students travel to this place and share Christ and His Word by personally interacting with them and demonstrating God's love for them.

1. BETHESDA REHABILITATION CENTER: FRONT ROW: D. Riddle, L. Bruening; MIDDLE ROW: D. Standridge, C. Weaver. J. Graham; BACK ROW: J. Zachary, G. Greve. P. Slusher, T. Danube. 2. SPRINGFIELD DETENTION HOME: A Morgan, J. Griswold, M. Nelson.

3. Dave Standridge communicates with the youths of the Bethesda Center.

4. Andy Simpson shows God's Truth to a young man at the Rescue Mission. 5. Chloe Parker gives her testimony at the Rescue Mission.

6. CINCINNATI RESCUE MISSION: FRONT ROW: C. Parker, J. Mishler, C. Whitestine: BACK ROW: J. Dannenberg. M. O'Quinn, K. Gaines, A. Simpson. 7. Andy Simpson teaches the Word of God to the men of the Rescue Mission.

8. Dave Standridge leads in a word of prayer.

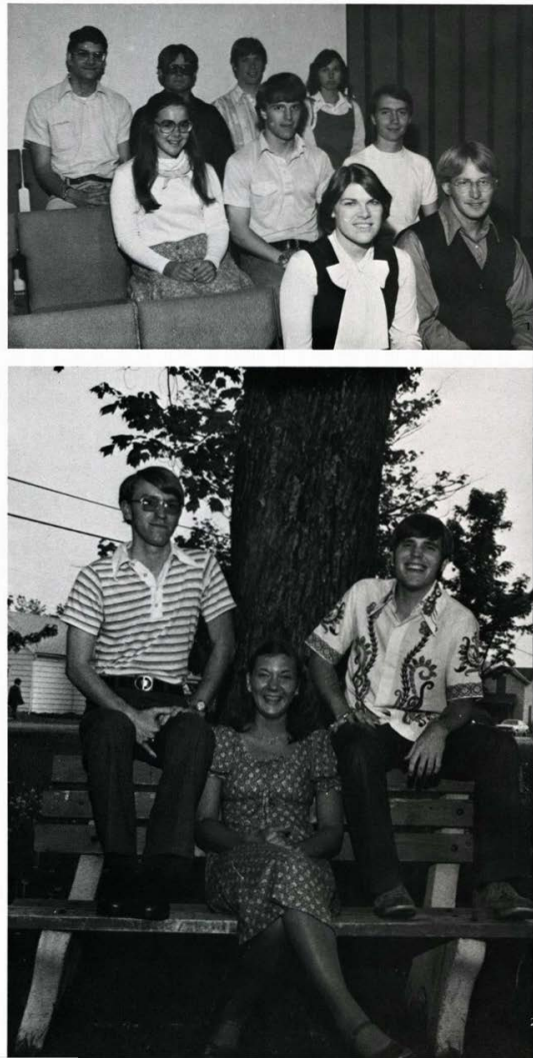



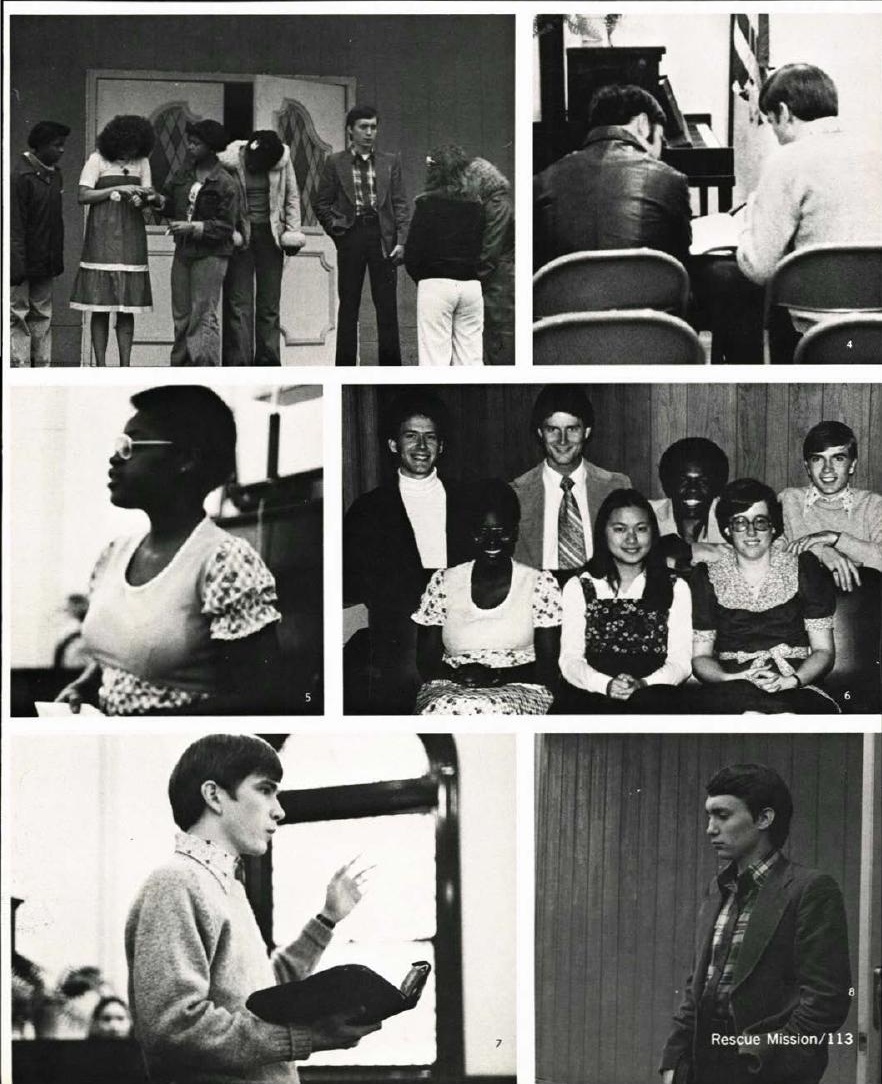


\section{Students Meet Needs Of Special People}

Barney's Children's Hospital allows Cedarville students to apply for volunteer positions on

its staff. The volunteers cheer

up children who are having physical difficulties or surgery.

By becoming acquainted with

the children, the volunteers

have opportunities to share

Christ's love for children and show them their need of Him as their Savior.

The Yellow Springs Riding Center gives Cedarville students a chance to communicate the Gospel to others while walking their horses.

A ministry to the mentally handicapped is accomplished at the Four Oaks School. Students

participate in various social, athletic and academic activities to aid the children in reaching their highest mental and physical maturation points.

1. BARNEY'S CHILDREN'S HOSPITAL: $N$. Lightner, C. Jacobs, V. Burleson. 2. The Four Oaks gang and the Cedarville bunch go on a hayride. 3. YELLOW SPRINGS RIDING CENTER: FRONT ROW: M. Schwenke, W. Kisner. M. Moore; BACK ROW: P. Michalski, C. Owen, D. Schieber. 4. FOUR OAKS TEAM: FRONT ROW: J. Bubel, C. Brown, B. Stewart, D Van Ryn; SECOND ROW: D. Miller. D. Mast. N. Addison, S. Bonzo; THIRD ROW: J. Prugh, D. Hartman; FOURTH ROW: B. Weller, R. Crompton, M. Jones, M. Peters.

5. Debbie Mast shares some "girl talk" with a Four Oaks' student

6. A barbecue by the Cedarville tennis courts is an activity enjoyed by all.

114/Barney's And Yellow Springs
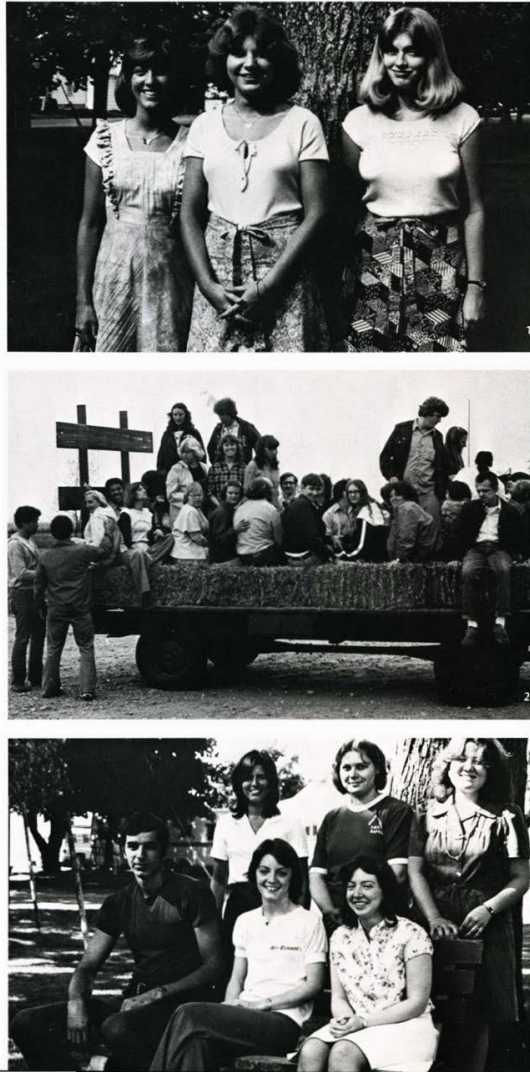

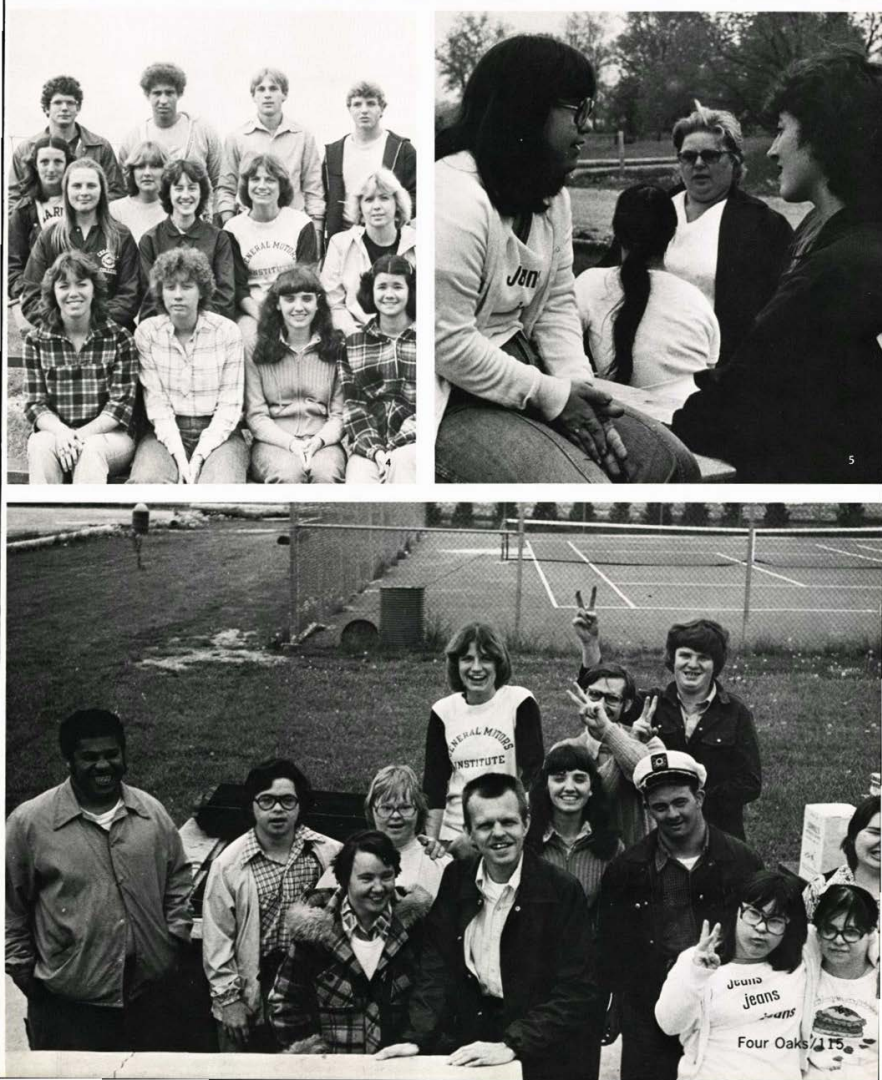


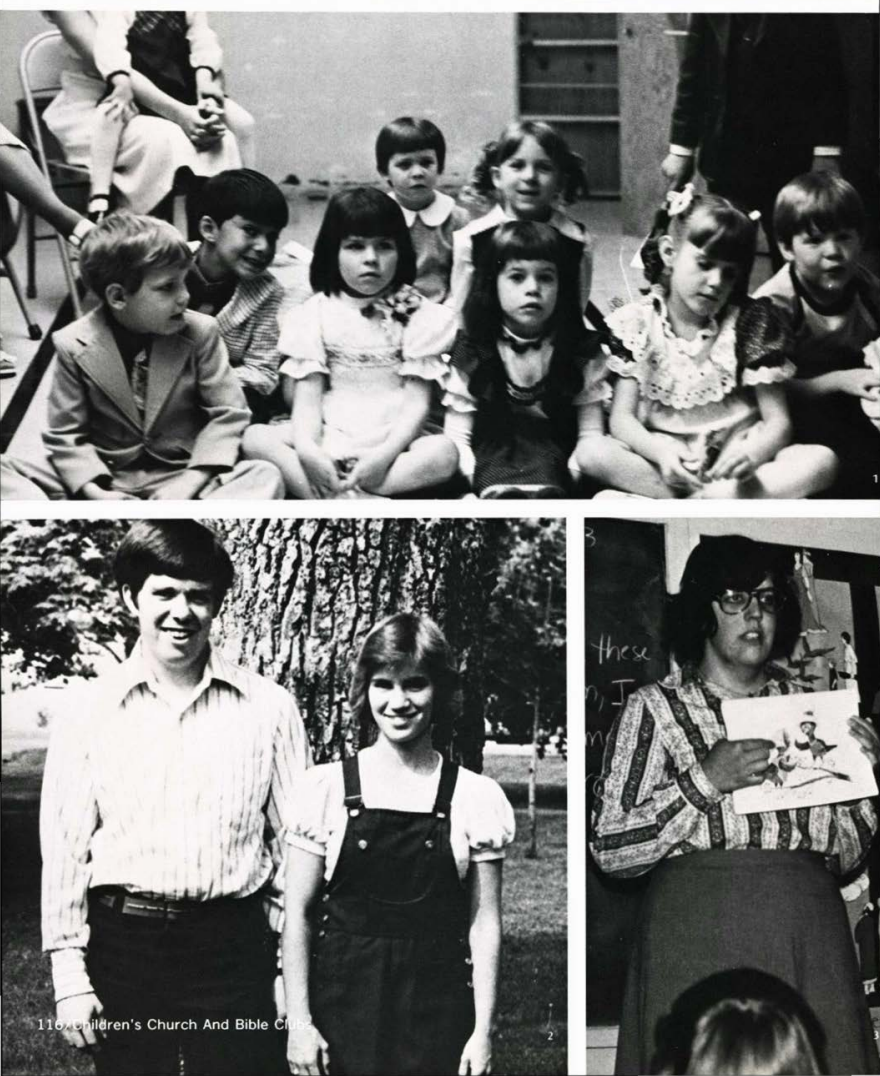




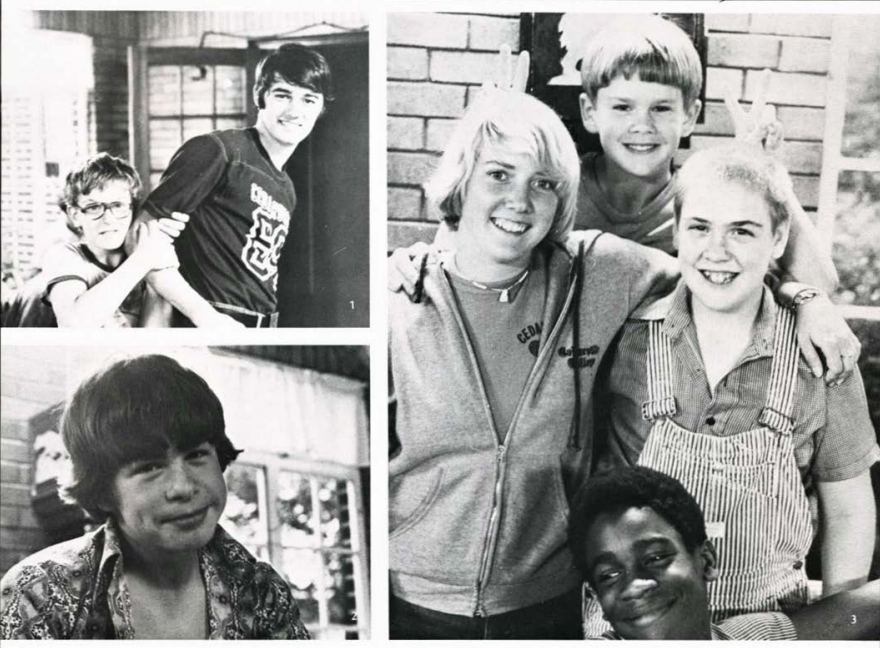




\section{Students Share The Gospel In Florida}

Over twenty students go to

Florida over the 1978 spring break to share the Gospel with others on the beaches. The students are divided into two

teams and they minister in different churches over the one Sunday that they are in Florida.

Staying in homes of contacts made previously, the students spend each day on the beaches

sharing God's revelation in

nature, His Word, and Jesus

Christ. The beaches are generally packed with college students, so Cedarville students can easily relate to them.

1. BEACH EVANGELISM: FRONT ROW: C. Zelonis, M. Shaw, K. Gaines, P. Edwards,

T. Yater, S. Piazza. D. Drozek: BACK

ROW: M. Cuttman, B. Lanphier, M. Lones, G. Decker, J. Erikson, C. Heatly. B. Vesilko, B. Myers, B. Rupe. C. Miller. D. Blackburn, B. Driscoll.

2. Ken Gaines befriends a lonely man.

3. Jan Anderson, Becky Rupe, Ginny Decker, and P.G. are amused by merely leaning against a beach wall.

4. Amy Ross and Bonnie Vesilko pose for a quick surside shot.

5. Craig Miller articulates God's Revelations to man through nature, His Word, and His Son.

6. Kathy Mallare familiarizes herself with the tract that will be sharing with others.

7. Russ Yoder attempts to open the communication lines with a young man. 8. Debbie Blackburn and Becky Driscoll

listen attentively, hoping to have a chance to share the Gospel with this gentleman.
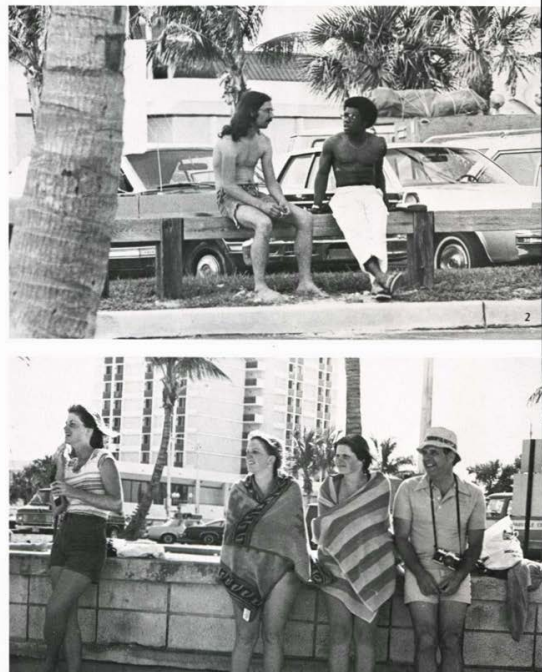


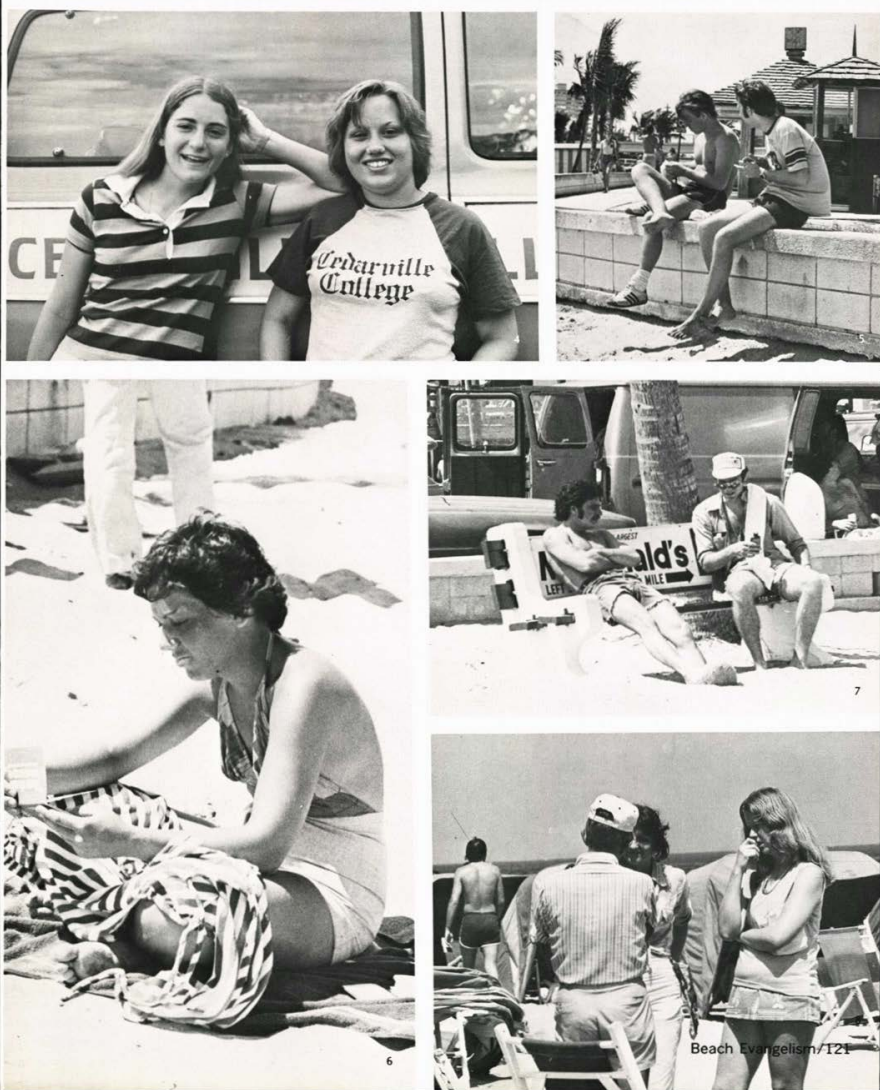




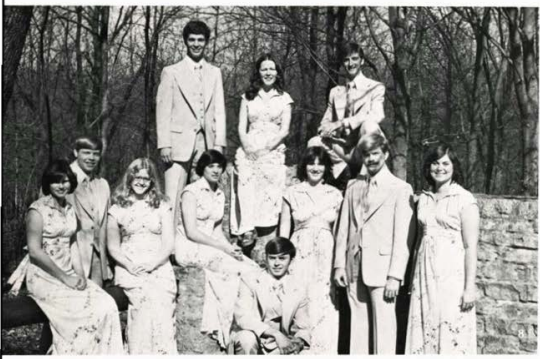

\section{Students Gain \\ Valuable Experience}

The Missionary Internship Service provides an opportunity for students to experience the ministry of Christian missions. If the service is abroad, the student can enlarge his mind culturally as well as spiritually.

The large task of planting indigenous New Testament churches can be aided by students who are willing to help. The 1978 M.I.S. group goes to Chad and Liberia, Africa, Brazil. Ireland, Israel, Philippine

Republic, Mexico, Indiana and Utah.

The 1978 Summer

Swordbearers travel in the midwest, bringing their wide-range ministry to local churches and camps.

1. ISRAEL: J. Veldt, \$. Arthur, M. Kirby, J. Jamison, D. Rowe. 2. AFRICA: S. Taylor (Chad), D. Drozek (Chad), R. Martin, D. Richardson (Chad) 3. BRAZIL WORK TEAM: FRONT ROW: R. Strobridge; BACK ROW: T. Knight, S. Smith, R. Smith.

4. FORTALEZA, BRAZIL: C. Sirka.

5. IRELAND: FRONT ROW: V. Maloney.

T. Danec: BACK ROW: A. Morgan.

6. MEXICO: E. Williams, Miss Carmen Shirk, C. Denny, L. McClure.

7. BRAZIL SINGING TEAM: FRONT ROW: J. Luce, L Goheen, N. Reitnauer, D. Messenger. W. Kisner, J. Bradshaw, B Few: BACK ROW: R, Connors, J, Riter.

L. West, D. Kisner (team leader) 8 1978 SUMMER SWORDBEARERS: FRONT ROW: $G$. Decker, $K$, Wilhite, $K$. Seymour, B. Hobar, B. Lanphier, S. Levin, M. Bentley (team leader), D.

Storch; BACK ROW: P. Miller, J. Leeke, S. Keller.

9. UNITED STATES: G. Longnecker (Utah), T. Hoganson (Utah), D. Seldon (Indiana).

10. PHILIPPINE REPUBLIC: $K$. Anderson. 11. PHILIPPINE REPUBLIC BASKETBALL TEAM: FRONT ROW: D, Green, $M$.

Streitmatter, K. Kauffman, J. Lantz, BACK ROW: T. Hutchison, B. Mick, B.

Riggs, F. Richer, Coach Don Callan. 


\section{Service And Musicianship Emphasized}

The Academic Advisory Board consists of some students from

each discipline. The Board is

chaired by Academic Dean

Clifford Johnson. They discuss issues that pertain to classroom activities.

The Advisory Twelve is a group of men that serve the Cedarville College Fellowship.

The Personnel Assistants are students, living in the dorms, who aid the Student Personnel office in spotting potential difficulties among students.

1. STUDENT ACADEMIC ADVISORY BOARD: L. Avery, P. North, M Cuffman,

D. Denny, A. Ross, S. Kuntzelman, S. Mesner, Academic Dean Clifford

2. ADVISORY TWELVE: M. Shaw, T. Paschall, J. Footman, M. Highman, R Campbell.

3. PERSONNEL ASSISTANTS: FIRST ROW: D. Blackburn, D. Jansen, L. Kuschel, L. Penquite, K. Anderson, D.

Gawthrop: SECOND ROW: L. Neal, B. Mosbacker, K. Wilhite, J Funtik, M. Smith; THIRD ROW: K. Erny, J. Leightenheimer, D. Hill, A. Young. $K$ Jones. C. Martin; FOURTH ROW: M

MCDougal, J. Jamison, P. Slusher, T. Stoner, M. Bentley, R. Globig, D. Clough

4. WIND ENSEMBLE: FIRST ROW: $P$ Kahl, A. Barker, D. Rothaar, T. Moore SECOND ROW: C. Heatly. B. Webber, S Logsdon, C. Supplee, B. Cotter, C. Staller, S. Lewis; THIRD ROW: T Anderson, K. Snyder, S. Titus, D McMurray, L. Roberts, D. Waterman, M Vincent, D Lord: FOURTH ROW: K Crandali, D. Cooley, A. Webber, R Wagner, B. Sparks, D. Begley, J. Mohler

T. Bos, Conductor Charles Pagnard, G Smith, J. Luce.

5. The Brass Choir performs at Honors Day.

6. The Wind Ensemble gives their annual home concert.

7. BRASS CHOIR: FRONT ROW: $K$ Crandall, N. Longnecker. D. Waterman, D. Lord, L. Stigers, D. McMurray. Conductor Charles Pagnard. T. Anderson, K. Snyder, S. Levin, D. Cooley, D. Begley: BACK ROW: A. Webber, J. Raber, T. Bos. 


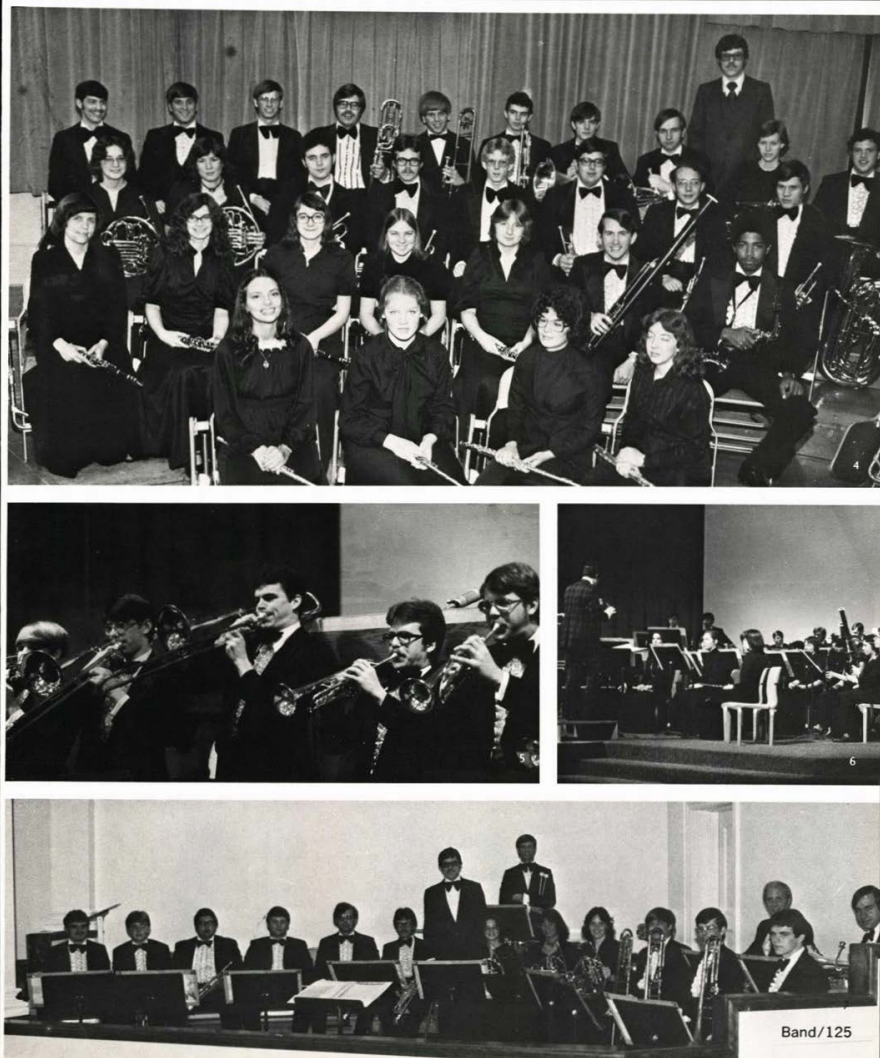



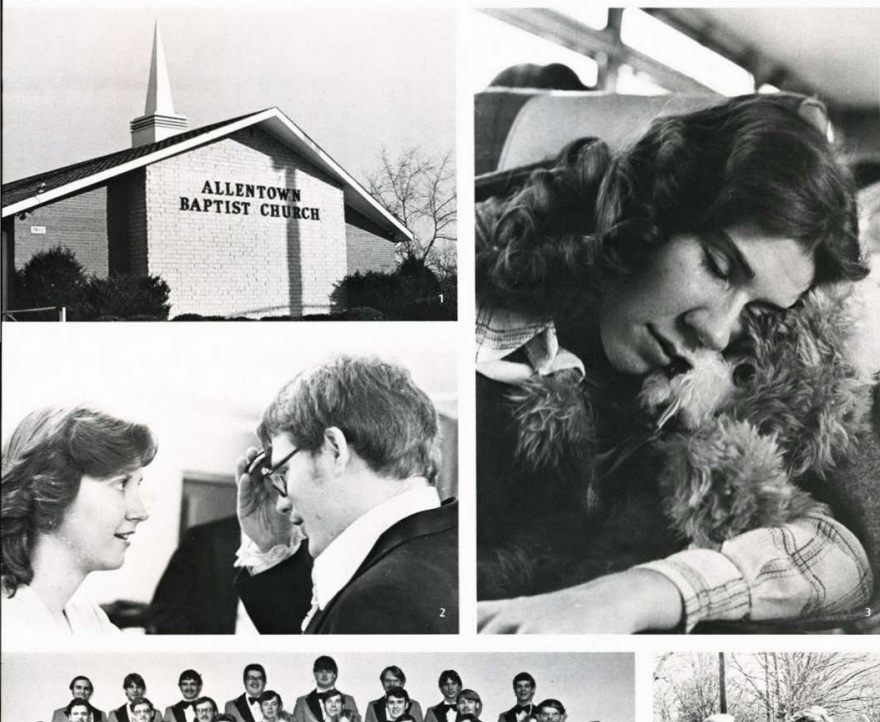

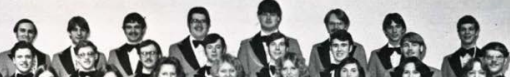
Anton 19 \%?

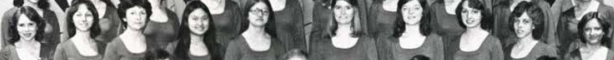

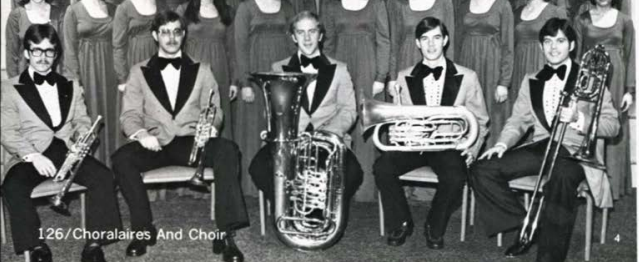

$H=5 x+w^{2}$

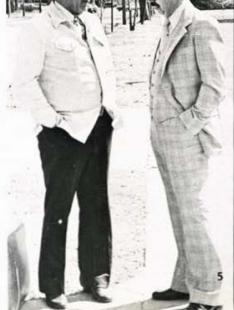




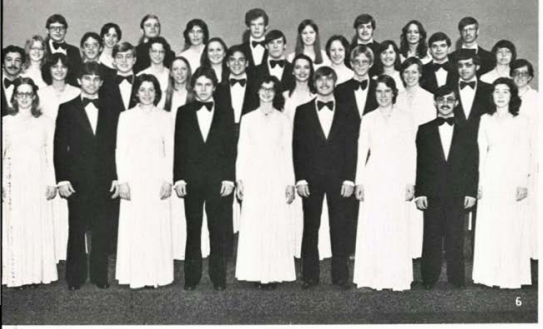

\section{Choir And Choralaires Conduct Tour}

The Cedarville College Music Department sends out two musical groups during spring break. The Concert Choir and Choralaires each conduct a tenday tour through various states. ministering to local churches and schools. This year the Concert Choir travels east to New York, New Jersey. Pennsylvania, and conclude their tour in Ohio. The Choralaires tour through Michigan.

1. The Concert Choir ministers in the Allentown Baptist Church on their tour. 2. Dan Hicks miraculously tunes the pitch pipe on his forehead as Diane De Nicola looks on with amazement.

3. Patty Reynolds cuddies up with a friend.

4. THE CHORALAIRES: FIRST ROW: $D$. McMurray, L. Stigers, J. Raber. J. Mohler, D. Ellington: SECOND ROW: C. Sprunger, J. Wheeler, P. Humphrey, J. Mishler, C. McLane, N. Unroe, K. Jones, N. Tenney, K. Hakes, F. Grahl; THIRD ROW: J. Traphagen, B, Kuhn, C

Mansfield, L. De Young. K. Brecher, D. Elmore, D Storch, S. Levin, M.

Reinholdt. C. Huffman; FOURTH ROW: J. Luce, P. Luce, G. Howe, S. Brown, J. Smith, C. Prokop, K. Chadrick, G. Nicholl: FIFTH ROW: Conductor Lyle Anderson, E. Wyse, J. Dutt, R. Connors, J. Limbaugh, B. Hayes, R. Phillips, P Miller.

5. Bus driver $\mathrm{Mr}$. Sizemore and Choir Conductor David Matson discuss travel plans.

6. THE CONCERT CHOIR: FIRST ROW: K. Faull, D. Lawhead, B. Adams, F Duley, B. Webber, M. Nelson, G. Ward, D. Wickman, P. Reynolds; SECOND RoW: D. Given, D. Wetzel, N.

Longnecker, J. Surso, J. Hart, P. Kahl, L. Roberts, G. Smith, D Maust, C Whitestine; THIRD ROW: K. Seymour. J. Hunt, S. Jenkins, L. Ramsey, J. Conklin, J. Riter, D. De Nicola, K. Amstutz, S. Knicely; FOURTH ROW: D. Hicks, D.

Spencer, R. Harper, K. Lapp, D. Price, J. Blasdell, P. Stoner, B. Beikert, A. Webber.

7. Lisa Ramsey takes the IMPERIAL taste test too seriously.

8. Jeft Conklin and Mike Brumbaugh unload the luggage. 


\section{Ensembles Edify Through Music}

A new ten-member ensemble traveling to churches on weekends is the King's Ambassadors.

Living Hope is a women's trio that travels on weekends to minister in Sunday morning and evening services.

The five-year old Abundant Life

Singers continue their total ministry in music to churches and schools. The theme verse of the group is John 10:10b: "I came that they might have life, and might have it abundantly.

Alethia is a four-member vocal and guitar ensemble. Their contemporary style is refreshing and edifying.

1. THE KING'S AMBASSADORS: FIRST ROW: C. Supplee, J. Luce, C. Heatly, R.

Young: SECOND ROW: G. Ward, K. Woods, D. Reid; THIRD ROW: P. Luce, R. Connors, M. Vincent. 2. LIVING HOPE: FRONT ROW: J. Pippin: BACK ROW: C. Phillips, J Surso, M. Forsten.

3. THE ABUNDANT LIFE SINGERS: FRONT ROW: B. Miller. R. Luedeke: SECOND ROW: D. Cobb, L. De Young, L. Avery. L. West; THIRD ROW: J. Willetts.

D. Dunn, J. Traphagen, R. Bigelow.

4. Lou Ann De Young and Dan Dunn minister through a vocal duet.

5. The Abundant Life Singers perform their home concert. 6. ALETHIA: FRONT ROW: J. Ward; BACK ROW: S. Browne, T. Broach, W. Throckmorton.
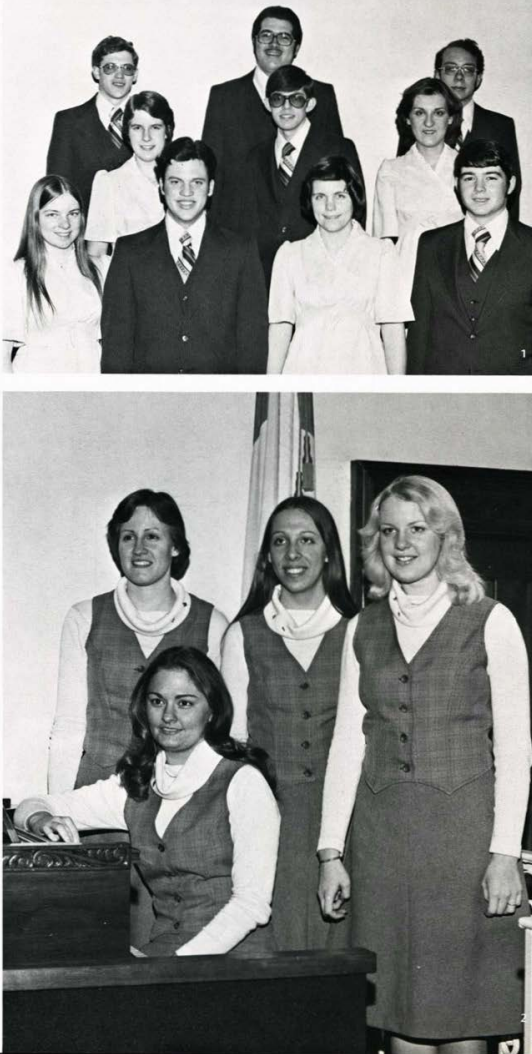


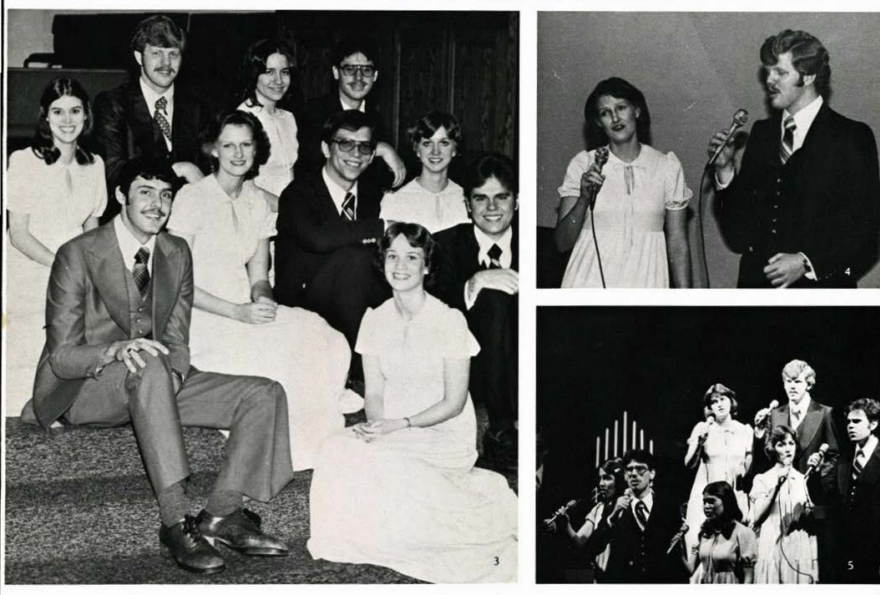




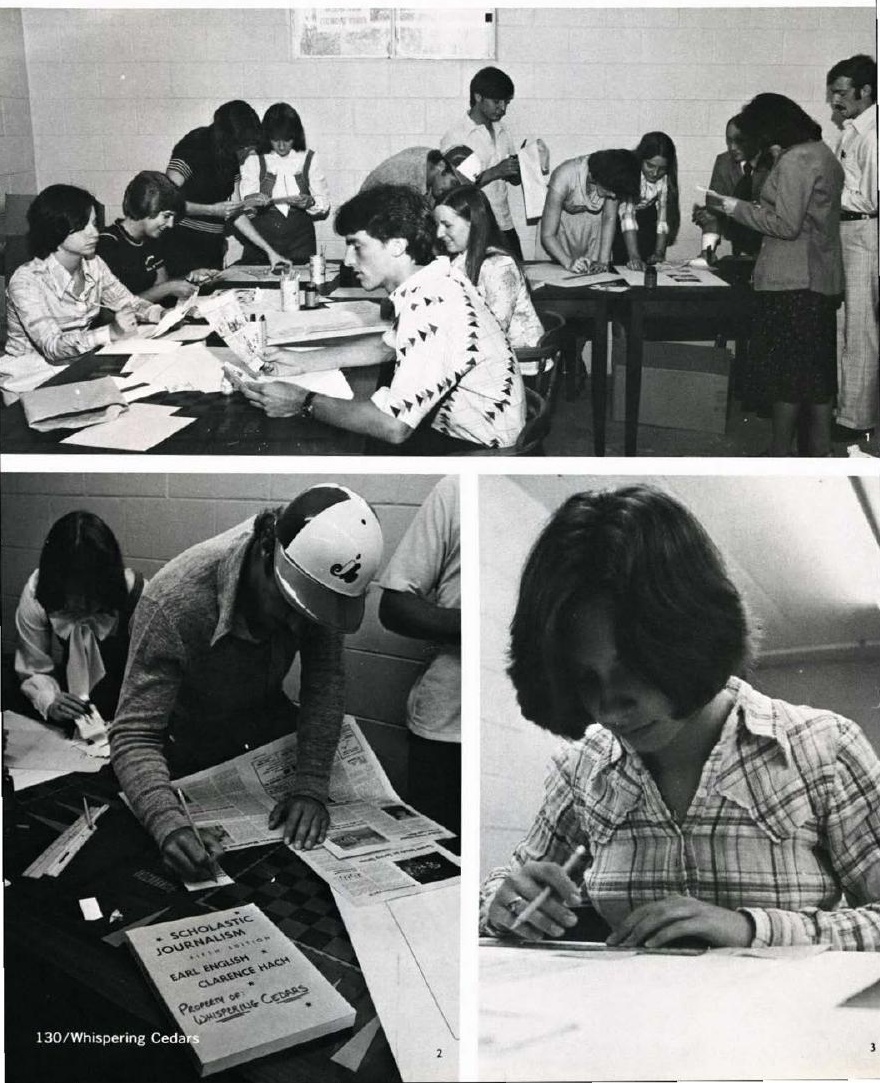




\section{Senate And SBP Provide Services}

The Cedarville College Student Senate is a voice for students to the administration. The Senate provides vending machines with assorted snacks and soft drinks.

A winter diversion is sought in the creation of the first annual

Ear Week. Professors and

students participated in activities centering around the auditory system.

The Student Body Project Committee consists of several students working together to

locate suitable projects on campus. This year SBP organizes a hopscotch marathon

to break the Guinnes World

Record. Rick Jones and Ron Wetzel hopscotch for 40 hours to break the previous record of 39 hours.

1. Dawn Curtis entertains at the First Annual Anatomy Award during Ear Week. 2. Dr. Ron Bigelow promotes the Health Service's new jumbo-size Q-tip.

3. Emcee Mrs. Pat Dixon is escorted by a furry Dick Walker.

4. STUDENT BODY PROJECT: FIRST ROW: S. Browne (chairman), R. Moore, M. Harris: SECOND ROW: C. Jacobs, R.

Campbell: THIRD ROW: R. Jones, R. Wetzel, B. Whitaker.

5. STUDENT SENATE: FIRST ROW: D.

Lewis, M. Harris, B. Neally, VicePresident Scott Bahorik, Secretary Bart Roth. Treasurer Jo Kiser, SBP Chairman Scott Browne, L. Kuschel; SECOND ROW: E. Parker, D. Sugg, B. Vesilko, R Jones, V. Maloney, W. Throckmorton, S. Brown, J. Haynes: THIRD ROW: N. Rehn, C. Olson, J. Wheeler, M. Shaw, D. Price

6. Student Senate President Scott Anderson moderates each Senate meeting. 7. Rick Jones and Ron Wetzel try hard not to fall asleep during the hopscotch marathon.

8. Rick Jones begins another game.
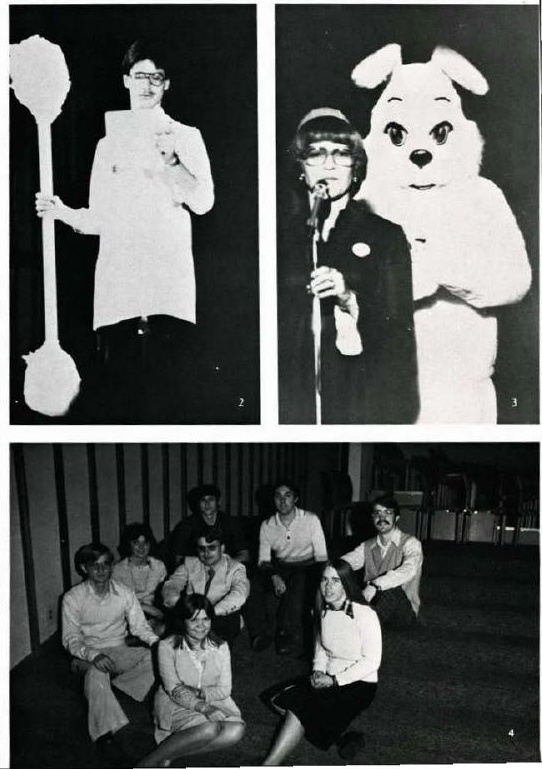


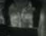

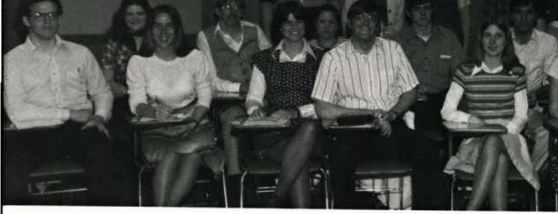

is

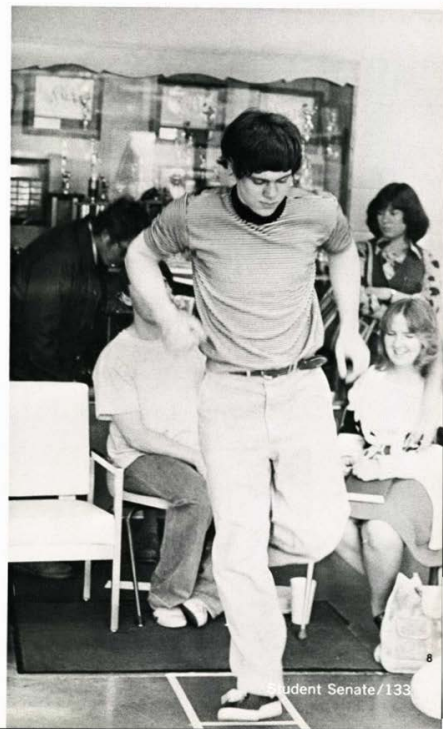




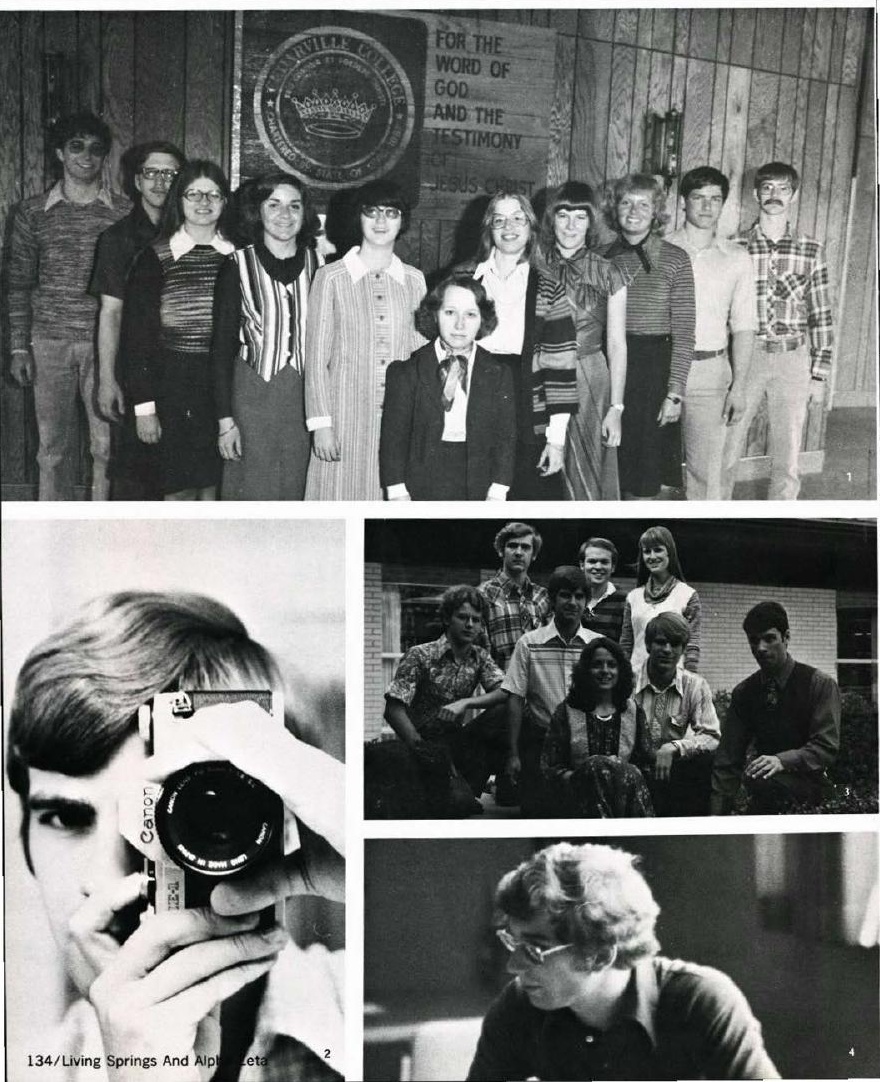



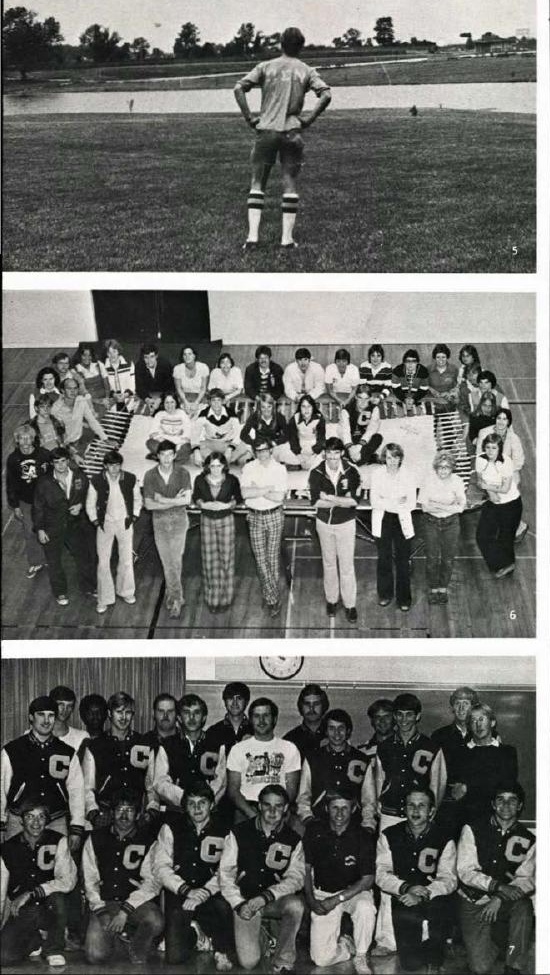

\section{Groups Fulfill \\ Vocational, Social Needs}

LIVING SPRINGS is a magazine published monthly for senior citizens.

Alpha Zeta is the campus photography club.

The Physical Education Majors and Minors organization is geared to promoting physical fitness among the college community.

Varsity " $\mathrm{C}$ " consists of those men who have lettered in at least one sport at Cedarville College

$\mathrm{Pi}$ Sigma $\mathrm{Nu}$ is a men's organization that develops the whole man. The club sponsors social and service for their members.

1. LIVING SPRINGS: M. Highman, B. King. C. McLane, T. Galbreath, J. Ebel,

P. Farmwald, K. Payne, L. Faull, D. Farmer, T. Paschall.

2. Greg Wickham focuses his camera for another yearbook shot.

3. ALPHA ZETA: FRONT ROW: D. Moses, G. Wickham, D. Tillson, C. Swank, E. Smith: BACK ROW: R. Meister, N. Rehn, D. Love.

4. Mark Highman is the Editor-In-Chief of LIVING SPRINGS.

5. PI SIGMA, NU: not pictured

6. PEMM CLUB: STANDING CLOCKWISE:

J. Colyer, B. Hull, M. Mignard, D. Lynch,

E. Gregory, N. MacKenzie, C. McMillan.

C. Clemons, J. Reep, J. Cross, L.

Palmer, B. Belleman, J. Conklin, C Anderson, S. Culp, P. Mullican, A. Phillips, D. Kearsley, R. Norton, B Hobar, J. Hutchins, B. Vinson, G. Johnson, R. Raabe, S. Taylor, T. Dowd, B. Hansen, R. Sprague, B. Fleming. B. Medlock; SEATED: A, MacDermaid

(Sec'y), M. McDougal (Pres.), Dr Pamela Diehl (Advisor). F. Greetham (Treas.).

7. VARSITY C: FIRST ROW: C. Colas, B. Belleman, T. Hutchison, F. Greetham, D. Hill, W. Rowe, G. Gromacki; SECOND ROW: J. Conklin, T. Benefiel, K. Erny, M. Allen, S. Anderson, T. Yater, D. Riddle; BACK ROW: R. Cagwin, K. Waiters, T. Williams. J. Potter, J. Lantz, P. Slusher. M. Streitmatter 

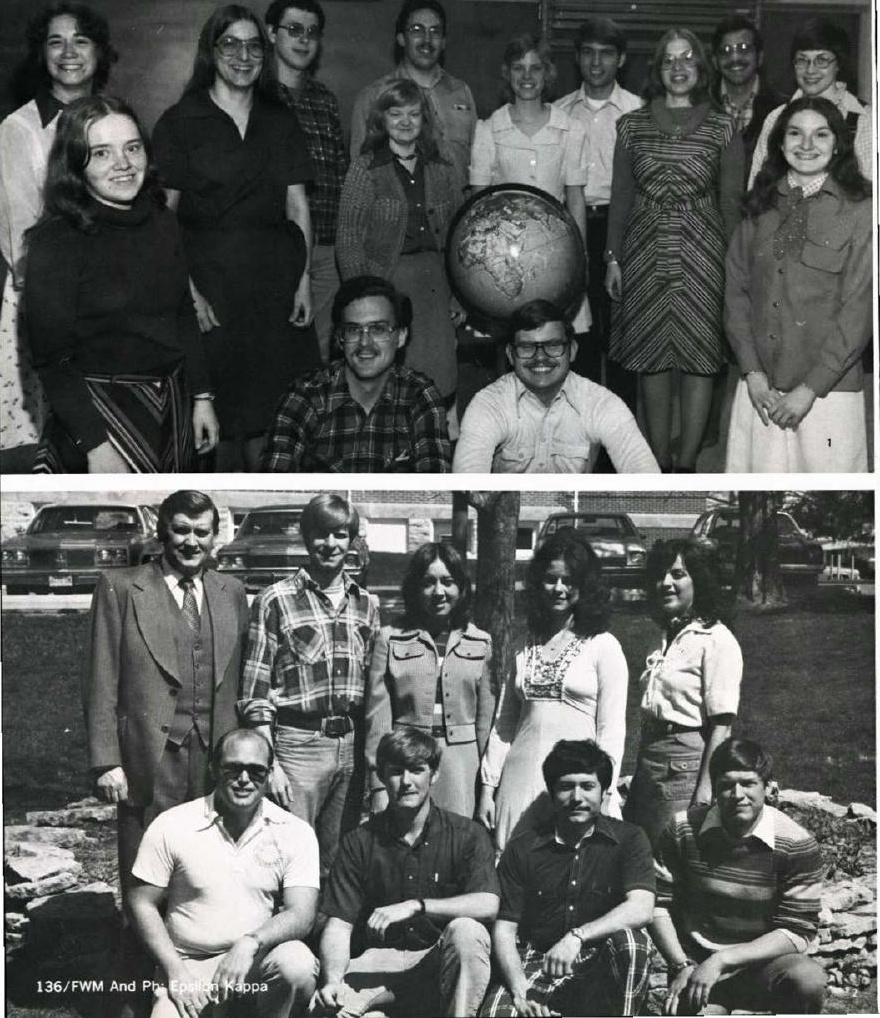


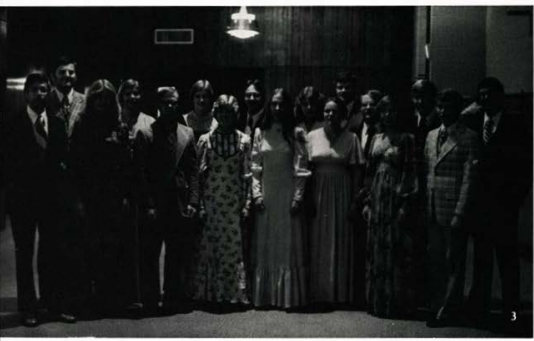

\section{Organizations Broaden Students' Horizons}

Fellowship of World Missions is a campus organization that prays specifically for missionaries and their families.

Timalathians is an organization that reads current literature on contemporary topics. The members meet frequently to discuss the sometimes controversial issues and questions raised in the literature.

Pi Delta is the campus tour organization. The primary activity of $\mathrm{Pi}$ Delta is conducting campus tours for visiting prospective students and church groups.

Phi Epsilon Kappa is advised by Mr. and Mrs. Parvin. The organization consists of those men and women who desire to enter some aspect of full-time Christian work.

1. FELLOWSHIP OF WORLD MISSIONS FRONT ROW: C. Lofgren, R. Wolff, B. Segerstrom, S. Moore; BACK ROW: T. Anderson, L. Yater, D. Hinks, L.

McClure, J. Veldt, K. Anderson, D

Richardson, K. Payne. T. Ruiz, L.

Everett.

2. PHI EPSILON KAPPA: FRONT ROW M.D. Anderson, B. Cave, D. Burns, T. Paschall; BACK ROW: Advisor Donald Parvin. T. Rowland, G. Bushong. D. Vernon, B. Driscoll.

3. PI DELTA: FRONT ROW: M. Castellani. D. Blackburn, J. Dailey, K. Anderson, J.

Surso, D. Shumaker, D. Kirk, D.

Richardson; BACK ROW: V. Lutman, $K$.

Dyer. C. Phillips, J. Veldt. C. Hargis, R. Yoder, G. Nicholl, D. Scott, B. Sabados. 4. TIMALATHIANS: STANDING: L. Fields. M. Sprano, D. Blackburn, C. Miller, K. Payne, C. Olson; TREE FRONT: $S$

Poling. B. Miller, T. Ruiz; TREE BACK: D. Moses, N. Rehn, D. Sugg, D. Fields. 


\section{Organizations Are Informative And Practical}

Chi Theta $\mathrm{Pi}$ is an organization that specializes in providing students with information about the health professions. Special speakers are brought in to share their experiences in health care. Missionary health personnel are invited to share that type of ministry.

The Education Club seeks to demonstrate current trends in Christian and public education. The organization also provides fellowship for students with common goals.

"Communicators for Christ" is the name of the newly formed radio organization. Broadcasting majors are members and they seek to learn more about the mechanics of operating a Christian radio station.

Village Players present Thorton Wilder's classic. "Our Town" in the fall and George Bernard Shaw's "Pygmalion" in the spring. The group seeks to broaden the students' education through drama.

The Music Educators National

Conference has a chapter at Cedarville College. MENC takes on another daring and difficult task in producing the longrunning Broadway hit, "Fiddler on the Roof." The purpose of the group is to acquaint students with the current trends in music education.
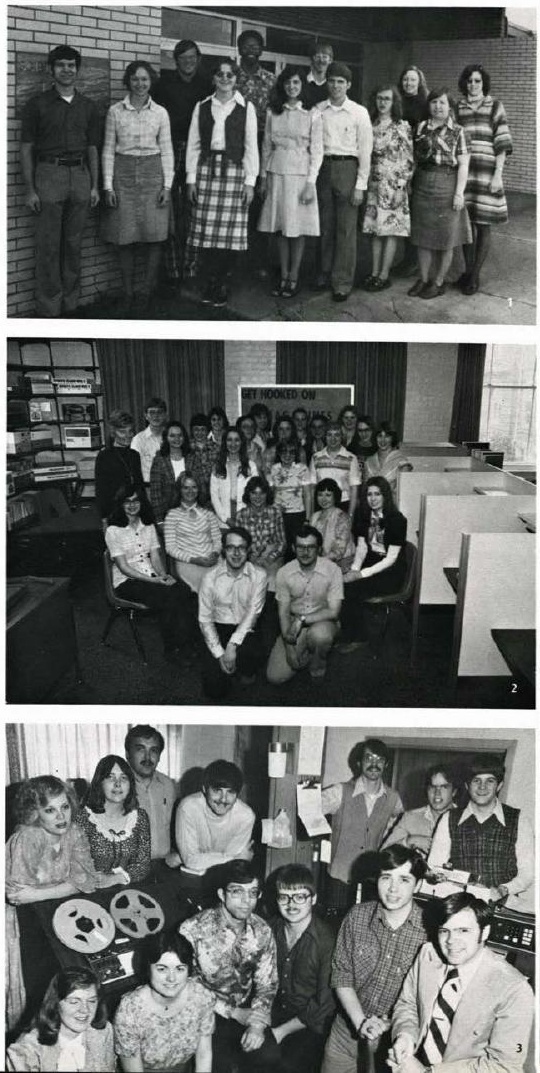

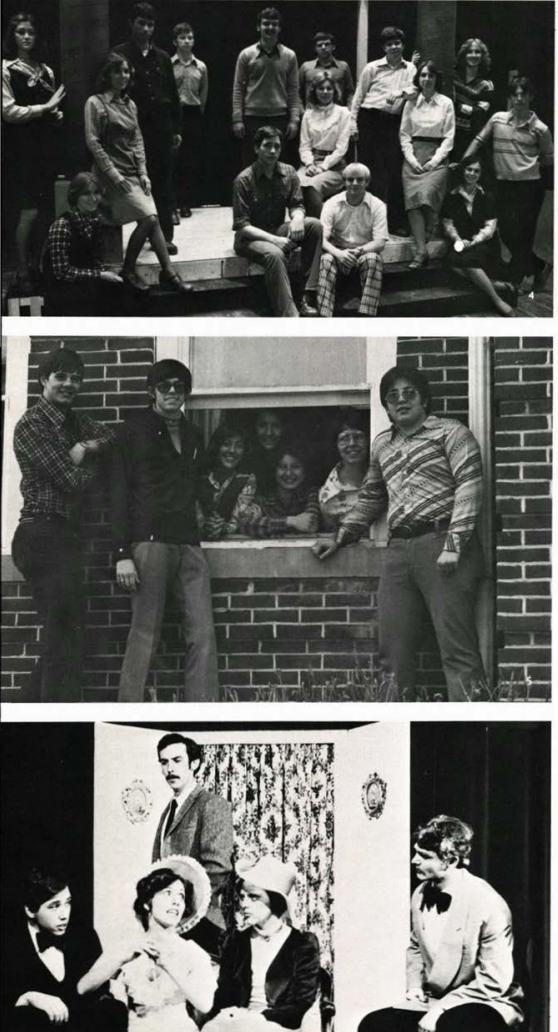

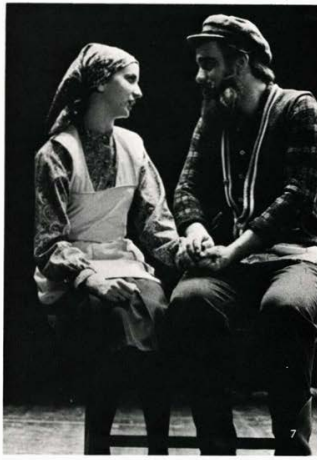

1. CHI THETA PI: FRONT ROW: D. Drozek (Pres.), S. Paradiso (Sec'y Treas.), D. Wiggin, B. Stewart, D. Richardson, N. Payne, K. Wainwright: BACK ROW: C. Colas (Chap.). T. DeShields, D. Sugg. J. Thomas, Y. Hewitt. 2. EDUCATION CLUB: FIRST ROW: D LaRue, G. Howe: SECOND ROW: B. Webber, D. Blackburn (V. Pres.). C. Jacobs, M. Horne, M. Humbert: THIRD ROW: Advisor Miss Marthat Dunn, J. Erikson (Pres.). L. Gradish, G. Putman (Sec'y). J. Reu, K. Putnam; FOURTH ROW: N. Longnecker, L. Everett, D. Shumaker, C. James, J. Graham, D. Keys; FIFTH ROW: J. Anderson, C. Hargis, D. Miller, G. Longnecker (Treas.). 3. COMMUNICATORS FOR CHRIST: FRONT ROW: L. Grafton (Sec'y). C. Keller (Treas.), M. Castellani (Pres.), R. Williams, J. Leightenheimer (V. Pres.). Advisor Wesley Baker; BACK ROW: D. Lawrence, B. Beckett, P. Howard, D. Poole, B. Whitaker, D. Stevenson, B. Mariage.

4. VILLAGE PLAYERS: CENTER: J. Leightenheimer (V. Pres.), J. Duff (Pres.). S. Zink (Sec'y). D. Adamson (Treas); BACKGROUND: R. Globig. C. Olson, D. Kirk, E. Smith, B. Bragg, D. Maust, T. Filler. J. Zachary. L. LaHaye, R. Phillips, Advisor Rebecca Baker. 5. MENC: J. Mohler, K. Woods, N. Lightner, J. Traphagen, C. Garrison, S Knicely, J. Acker.

6. The principals of G.B. Shaw's

"Pygmalion" do a creditable job.

7. MENC's production of "Fiddler on the Roof" stars Jon Raber and Lydia West. 


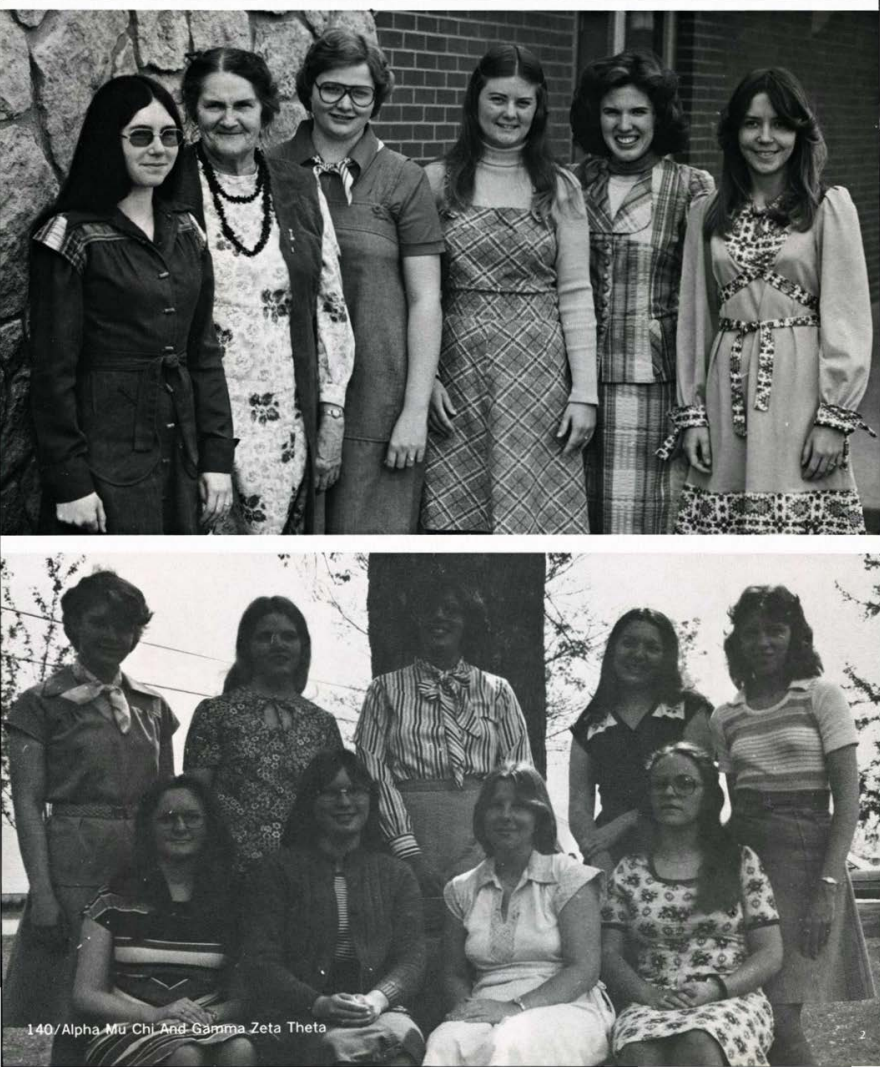




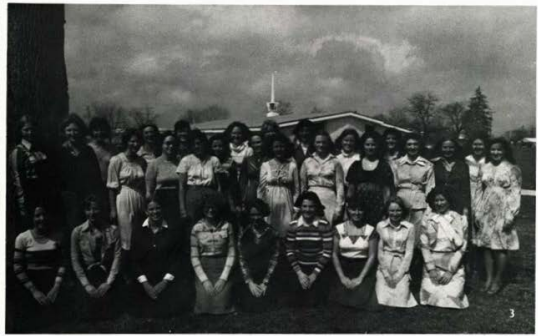

\section{Women \\ Fellowship Spiritually And Socially}

Gamma Zeta Theta and Gamma Chi are two womens service organizations on campus. Gamma Chi sponsors an annual spring banquet while Gamma Zeta Theta sells chrysanthemums during the fall Homecoming festivities. The two groups have retreats, guest speakers, and social activities to enhance their Christian leadership abilities.

Alpha $\mathrm{Mu} \mathrm{Chi} \mathrm{is} \mathrm{an} \mathrm{organization}$ for engaged women. The group sponsors activities that center around planning a memorable wedding, choosing appropriate bridal fashions, and building a successful marriage. A composite bridal shower is the final activity of each year.

1. ALPHA MU CHI: M. Emery, Advisor Beatrice Printy, J. Arthur, S. Dawson, S. Cartan, D. Gawthrop

2. GAMMA ZETA THETA: SEATED: C. James, T, Varhola, J Cobb, D.

Shumaker: STANDING: B. Prentice, G. Longnecker, E. Williams, R. Rogers, C. Hargis.

3. GAMMA CHI: FIRST ROW: D

Gawthrop, D. Kelso, M. Filmer, K. Haga, S. Roth, B. Adams, A. Young, D

McDaniels, K. Snyder; SECOND ROW: D,

Robery. T. Danec, D. Morgan, A. Hallet,

S. Board, M. Howard, B. Major, L. Wisnoski, L. Goheen, D. Vernon, B. Stewart, L. Neal, L. Burchett, W.

Patterson; THIRD ROW: C. Smith, D. Festag, M. Greve, D. Drummer, K. Brecher, K. Lapp, S. Zink, K. Johnson. 4. Tammy Danec and Jeff Conklin greet the guests at the "Touch of Class"

Gamma Chi Banquet. 


\section{Alpha Chi Has An Active Year}

Alpha Chi is the leading men's organization on campus dedicated to service to the school. It also seeks to build

Christian character and leadership into each man. A fall banquet is given at the 4-H

Recreation Center in Clifton, Ohio. It takes the form of a barbecue and entertainment is provided after the meal. Alpha Chi sponsors two college rings days throughout the year as well as planning the annual Cedar Day.

The Alpha Chi Sweetheart for 1978 is Cindy Hall. Miss Hall is crowned at a February basketball game. She is attended by Karin Angel, Debbie Blackburn, and Joan Surso.

1. ALPHA CHI: FIRST ROW: S. Hoy (Historian), T. Altimus (President), S Miller (Treasurer). Alan Moragan (Membership Coordinator): SECOND ROW: D. Cremean, B. Kaufman, C. Sarver, R. Campbell, B. Whitaker, D. Cobb, D. Burns; THIRD ROW: R. Pope,

A. Grenier, S. Churchill, R. Matter, J Dannenberg, R. Wetzel, D. Campbell: FOURTH ROW: D. Hicks, B. Hansen, D.

Francis, C. Birch, J. Driscoll, J. Hunt.

2. Terry Broach and Jearl Ward entertain at the October Alpha Chi barbecue.

3. 1977 Alpha Chi Sweetheart Mary Humbert turns the title over to Cindy Hall.

4. Alan Morgan plants a cedar tree as Sweetheart Cindy Hall and Attendant Joan Surso observe. (Attendants Karin Angel and Debbie Blackburn not pictured)

5. Dave Burns and Diane Vernon settle their differences in a friendly game of Battleship.

6. John Dannenberg looks prepared to spend a snowbound weekend at the Alpha Chi Retreat held a Sky View Ranch.

7. ALPHA CHI RESCUE SQUAD: FRONT ROW: C. Birch, M. Leach; BACK ROW: R Burkhart, G. Chamberlain, D. Francis, M. McFadden.

8. Bob Hansen loses his toboggan as he slides down the hill.

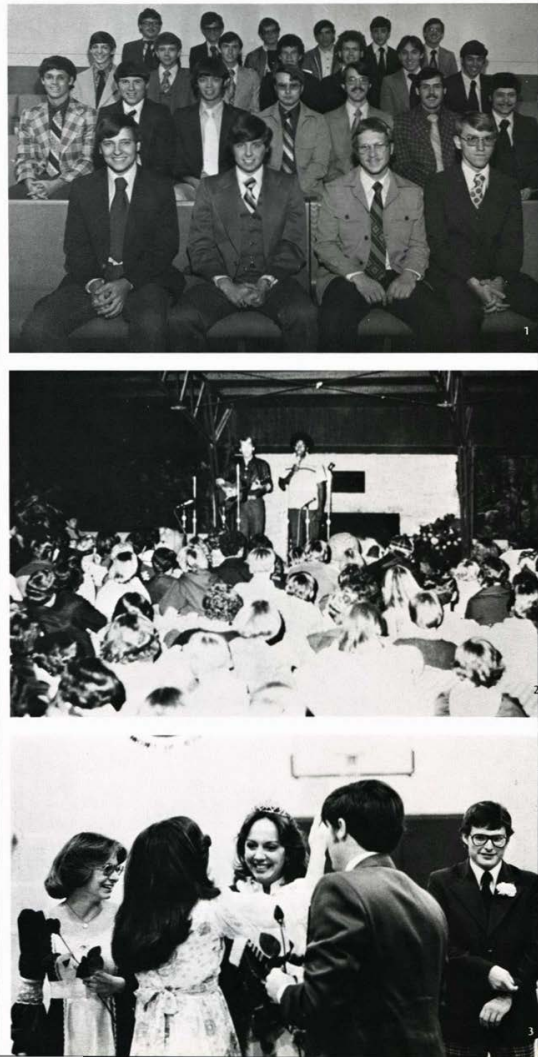



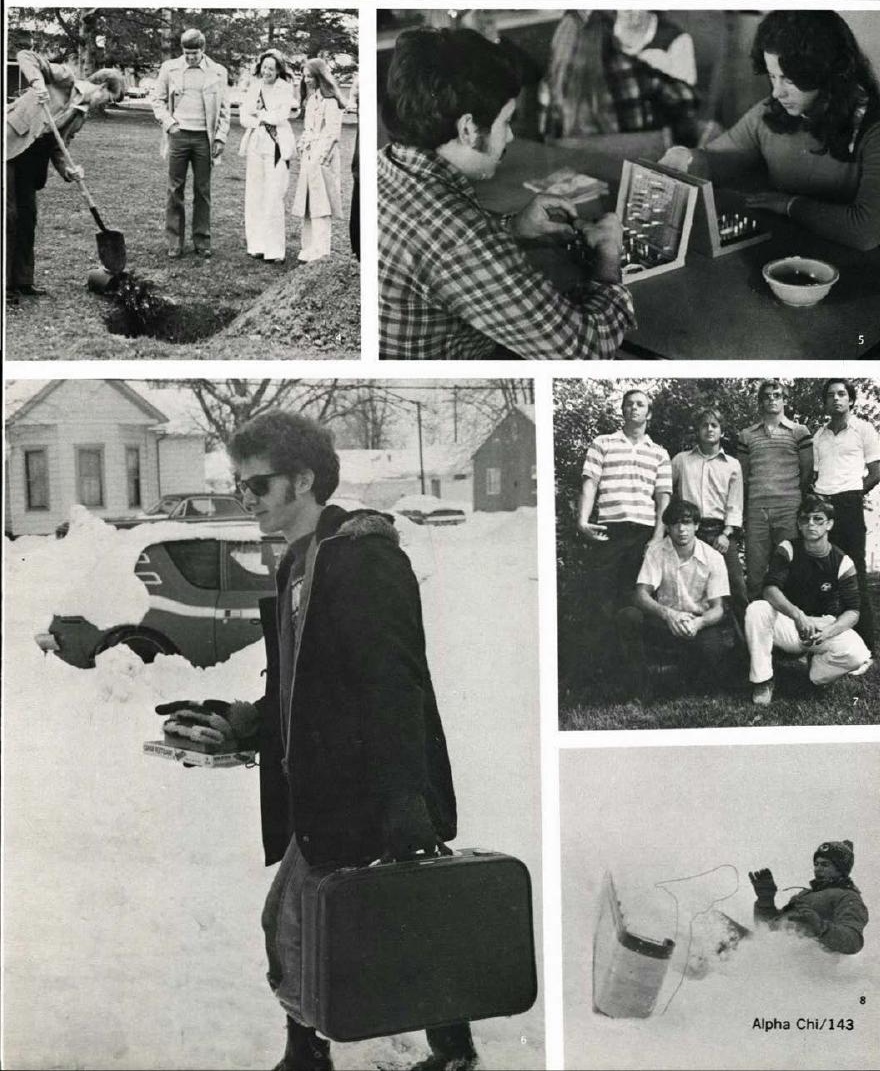


\section{Candid Cedarville}

1. The cafeteria spinach is always a tasty delight. 2. During finals, the library is packed to the doors

3. Gary Gromacki hopes for par or less on the next hole.

4. Mary Humbert and Karen Lapp concentrate in a serious game of "Pit." 5. Debbie Van Ryn and two Four Oaks" students enjoy a hot dog roast by the tennis courts.

6. While on tour, the Concert Choir viewed this Smithsonian replica of the Capital Building. 7. Intramural flag football is a popular diversion in the fall quarter. -8 . Cal Swank dares anyone to stare him down.

9. "Paula, why are your fingernails digging into my hand?" Wynn Gifford painfully asks.

10. "This year Cedarville, next year Wimbledon!" exclaims Amy Ross to Craig Miller after winning a $\# 1$ singles match
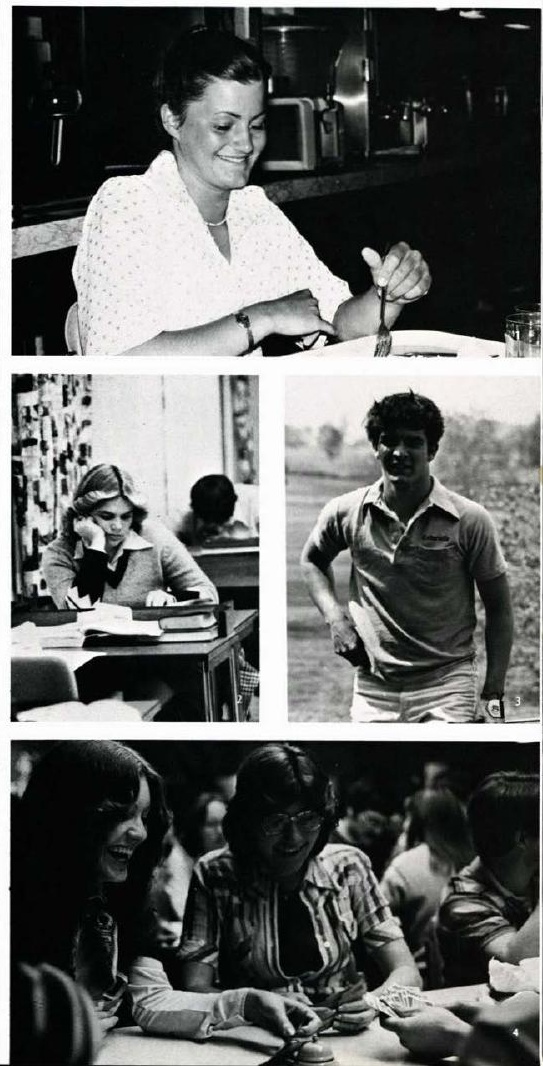

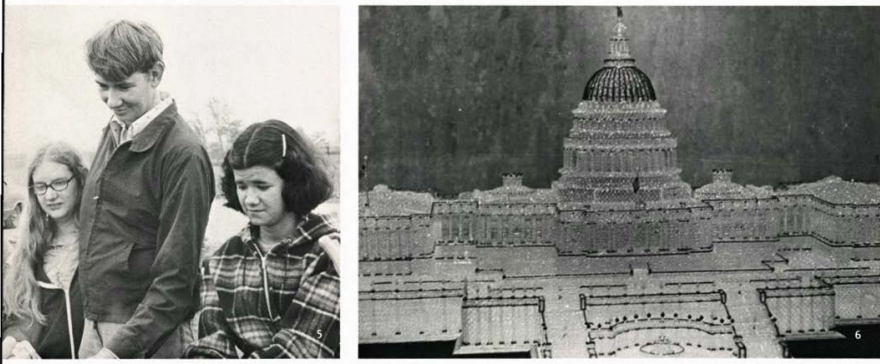

6.

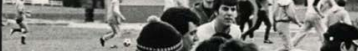
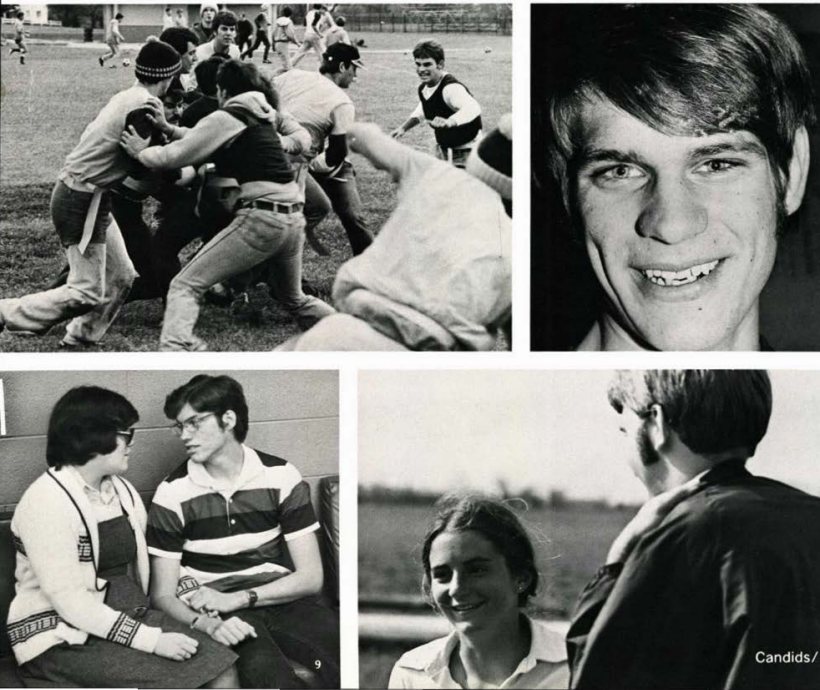

8

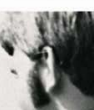




\section{Administrators Chart Course Of The College}

1. JAMES T. JEREMIAH, D.D., Litt. D., President

2. DONALD RICKARD, M.A., Dean of Students

3. LEE TURNER, M. Div., Director of Development

4. CLIFFORD JOHNSON, Ed.D. Academic Dean

5. KENNETH ST. CLAIR, M.A., C.P.A. Business Manager

6. TRUSTEES OF CEDARVILLE COLLEGE

Back Row:

EARL WILLETS, Berea, Ohio

JACK CLINE, Rockbridge, Ohio GERALD SMELSER, Orrville, Ohio JAMES CARRAHER, Secretary, Sylvania,

Ohio

ARTHUR DYKE, Elyria, Ohio CHARLES BARTH, Poland, Ohio

PAUL VERNIER, Fairborn, Ohio

IRWIN OLSON, Indianapolis, Indiana GEORGE O'BRYON, Eldora, lowa JOHN DRAXLER, North Royalton, Ohio

GALEN CALL, Covington, Kentucky FRANCIS BRESSON, Sussex, Winconsin JACK JACOBS, Haddon Heights, New Jersey

GEORGE ENGELMANN, Burton, Michigan

Front Row

DONALD TYLER, Vice-Chairman, Brownsburg, Indiana J. DALE MURPHY, Chairman, Waterloo,

lowa

JAMES T. JEREMIAH, Cedarville, Ohio WILLIAM BROCK. Treasurer, Columbus, Ohio

Not Pictured

RUDY BEDFORD, Toledo, Ohio GLENN DAVIS, Lancaster, Ohio

ROY GUENIN, Laurinburg. North Carolina

WILLIAM PATTERSON, Parma, Ohio ROBERT SUMNER, Brownsburg, Indiana

PAUL TASSELL, Des Moines, lowa EARL UMBAUGH, Stow, Ohio

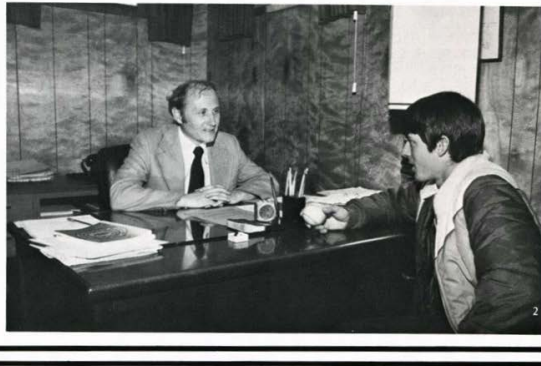




\section{Employees Increase Outreach Ministries}

CHRISTIAN SERVICE OFFICE

1. MARGARET GREEN. Secretary to

Director of Christian Service

2. KATHLEEN HOWELL, B.A., Music

Coordinator

3. Back Row:

DAVID LYONS, Assistant Director of

Christian Service in charge of

Swordbearers BETH BEIKERT.

Receptionist Front Row:

DAVID KISNER, Assistant Director of

Christion Service in charge of Church and Social Ministries

BRUCE MCDONALD, B.A., Assistant

Director of Christian Service in charge

of Campus Evangelism and Penal Institutions

4. HAROLD GREEN, Th.B., Director of Christian Service WCDR RADIO STATION

5. DANE ROHM, B.A., Station Manager

6. DAVID BOSTON, 1st Class F.C.C.

License. Chief Engineer

7. PAUL GATHANY, ist. Class F.C.C.

License, General Manager

8. DAVID ROCK, Program Operations Director

9. JACQUELINE PYLES, Secretary
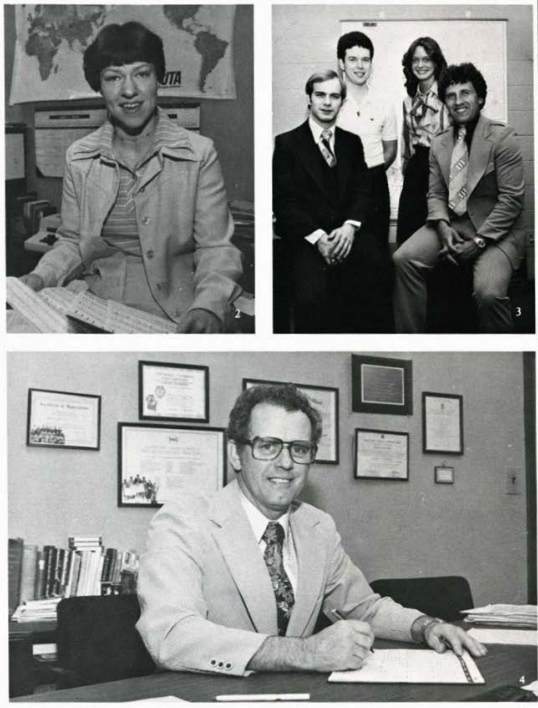

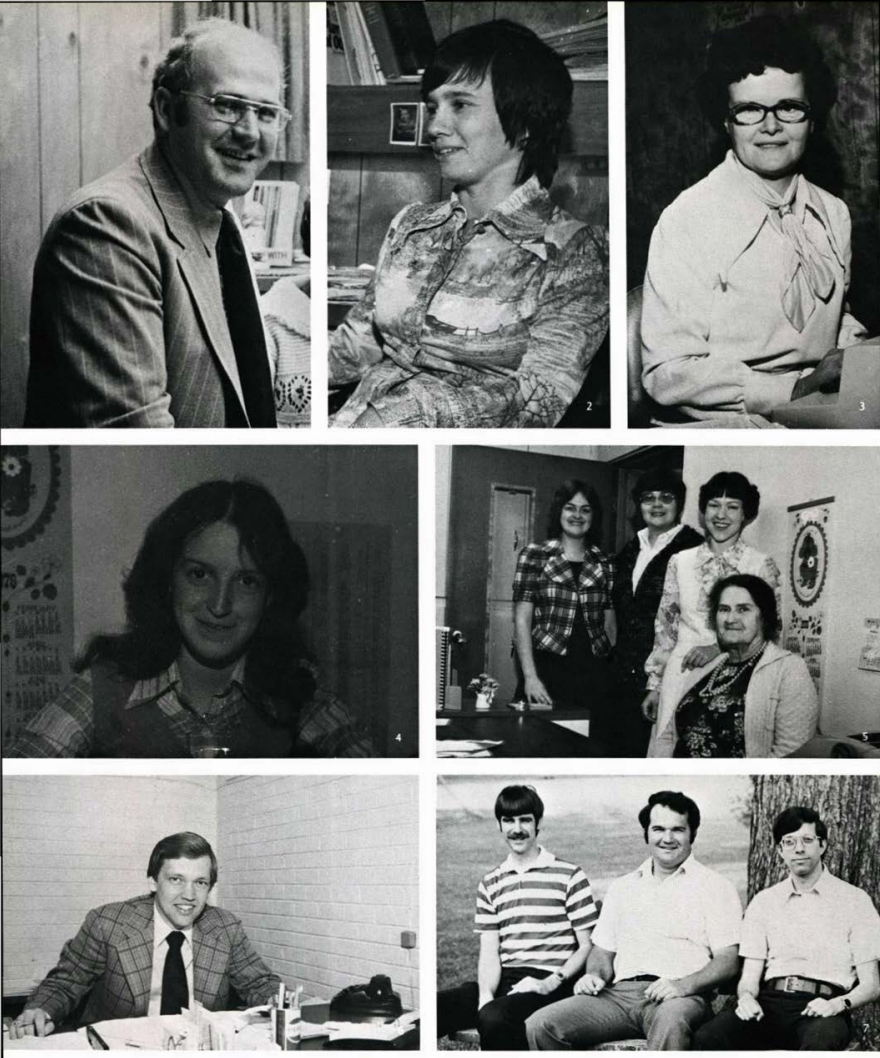


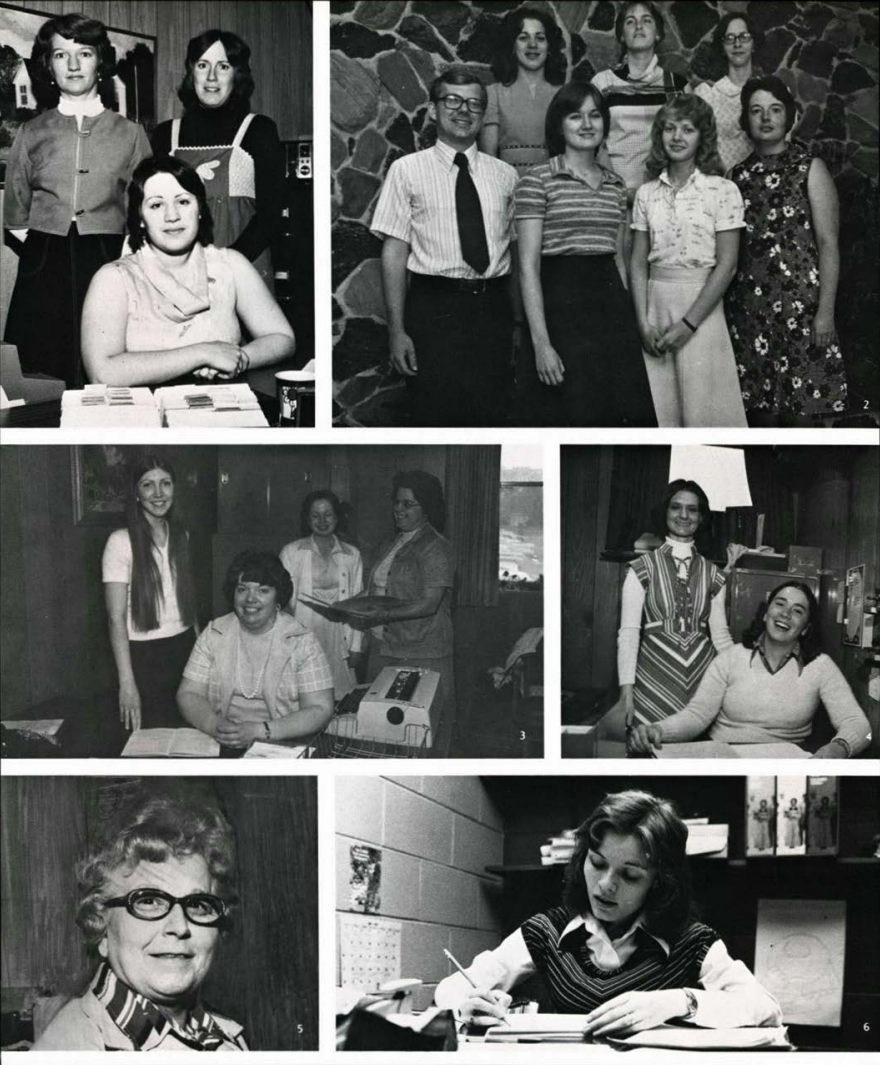




\section{Practical Studies Are Emphasized}

BUSINESS ADMINSTRATION DEPARTMENT:

1. WILLIAM RITER, M.S. C.P.A. Associate Professor of Accounting. Chairman

2. RICHARD BALDWIN, M.B.A., L.L.B.

Assistant Professor of Business

3. JAMES SEAMAN, Ph.D., Assistant Professor of Marketing Management EDUCATION DEPARTMENT:

4. BEVERLY MONROE, M.A., Assistant Professor of Education

5. JIM BIDDLE, Ph.D., Assistant Professor of Education. Acting Chairman

6. PAUL CARLSON, Ph.D.. Part-time Instructor of Education

7. MARTHA DUNN, M.A.. Assistant Professor of Education

8. HELEN HALL, M.A., Assistant Professor of Education

9. IRMA DODSON, M.A., Professor of Education

10. RONALD CORIELL. M.A., Part-time Instructor of Education 11. DWAYNE FRANK, Ed.D., Professor of Education
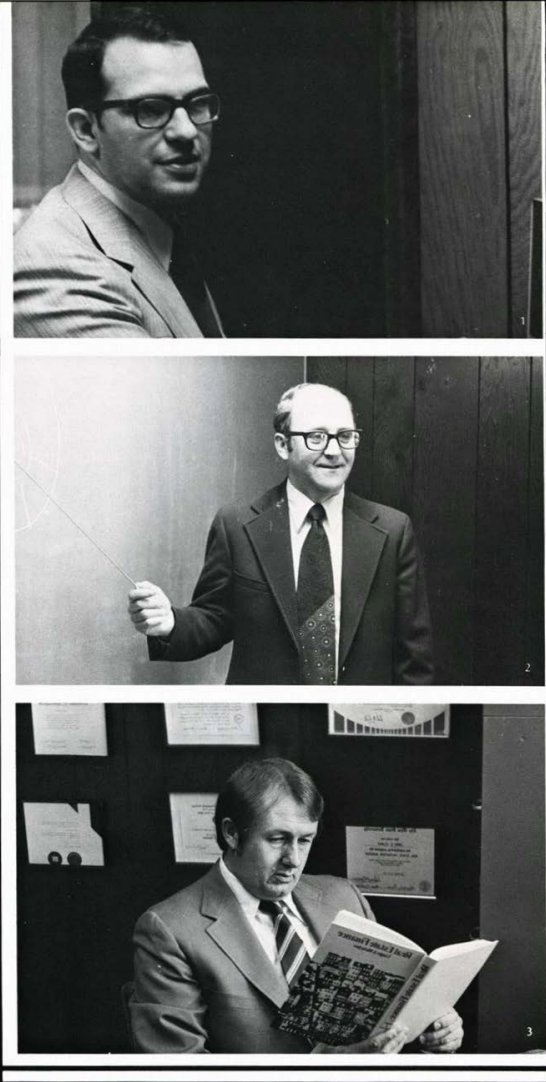


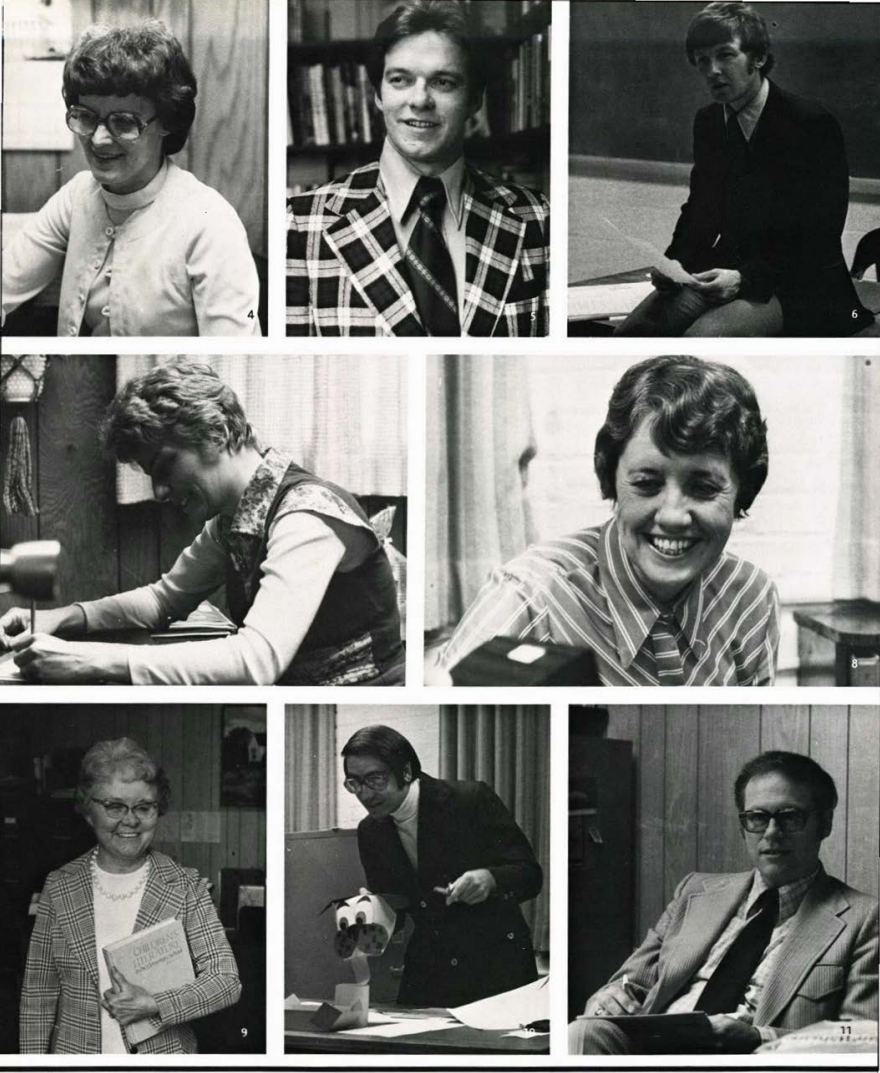




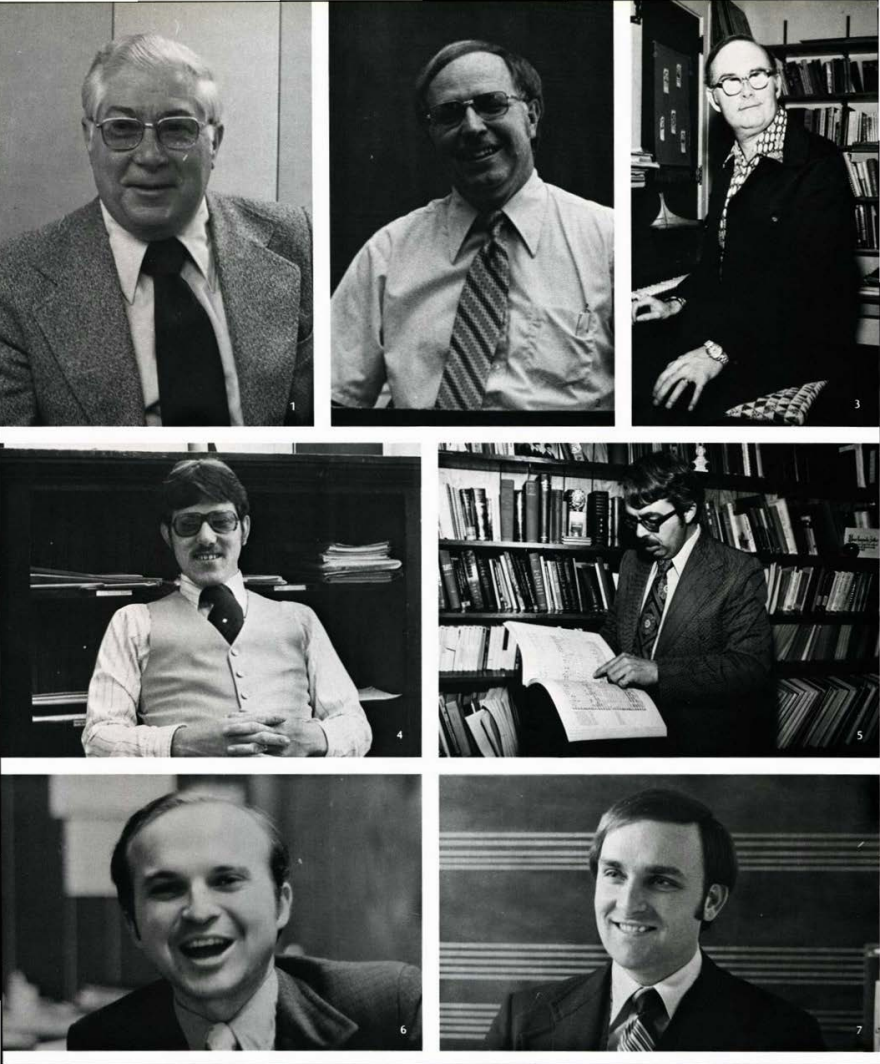




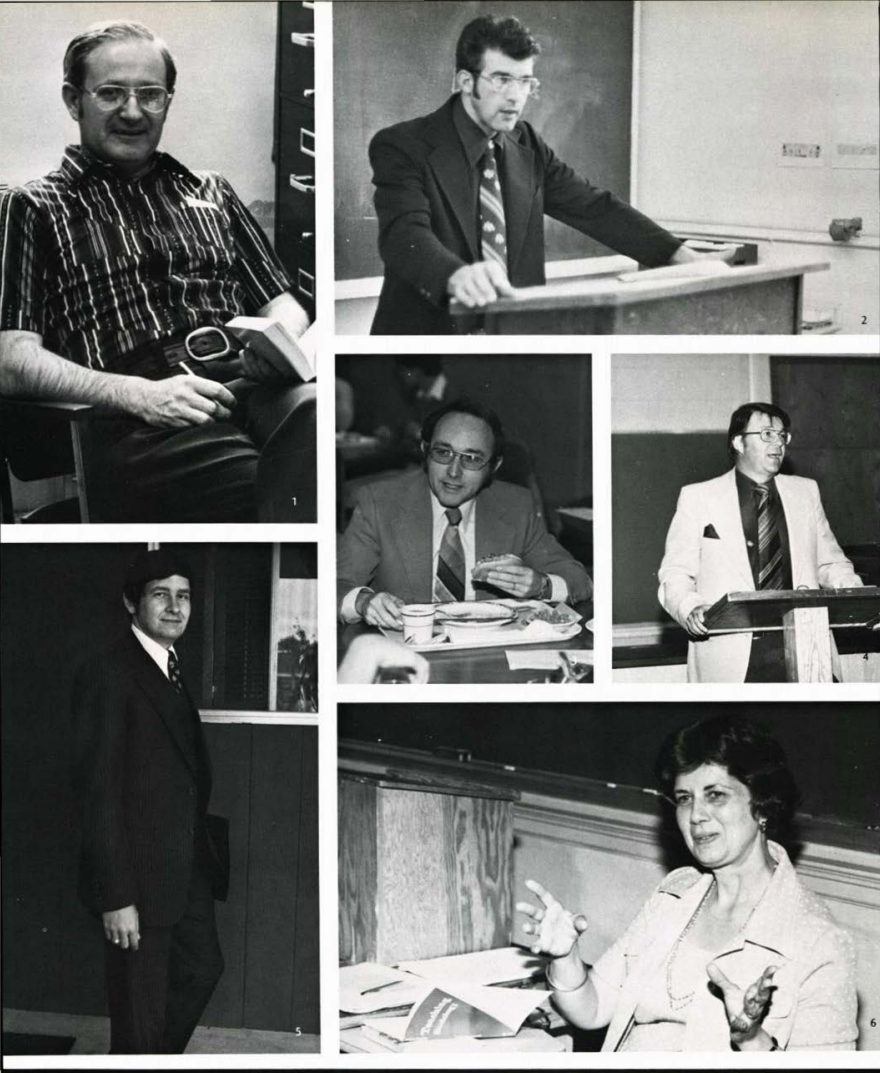




\section{Comprise Class Of 1981}

The Freshman Class is comprised of approximately 382 members. They particpate in activities that include Sadie Hawkin's race, roller skating. bowling, and several gym nights.

Their members are eager to be involved in the activities and events offered to them. Their enthusiasm is refreshing to the somewhat "booged-down" upper classman. This enthusiasm should be continued to keep Cedarville's zeal alive.

1. The Freshman Class attempts to locate their shoes after a Sophomore-

Freshman game night in the gym.

2. FRESHMAN CLASS OFFICERS: SEATED: Tom Paschall (Chaplain), David Price (Student Senate), Cheryl McMillan

(Secretary): STANDING: Rick Jones

(Student Senate), Valde Garcia

(President). Randy Meister (VicePresident), Ted DeShields (Treasurer). 3. Pam Kahl believes in moisturizing her scalp with a rich lather before having her head shaved.

4. Rhonda Hettinger exhibits her winning

5. Only a few ownerless shoes remain after the orientation gym night given for

the Freshman Class by the Class of 1980 .

6. Betsy Froh waits for a special phone call.

7. "Help me, help me, my curlers are too tight!" cries a South Hall resident in anguish

8. For an incoming Freshman, the registration lines seem endless.
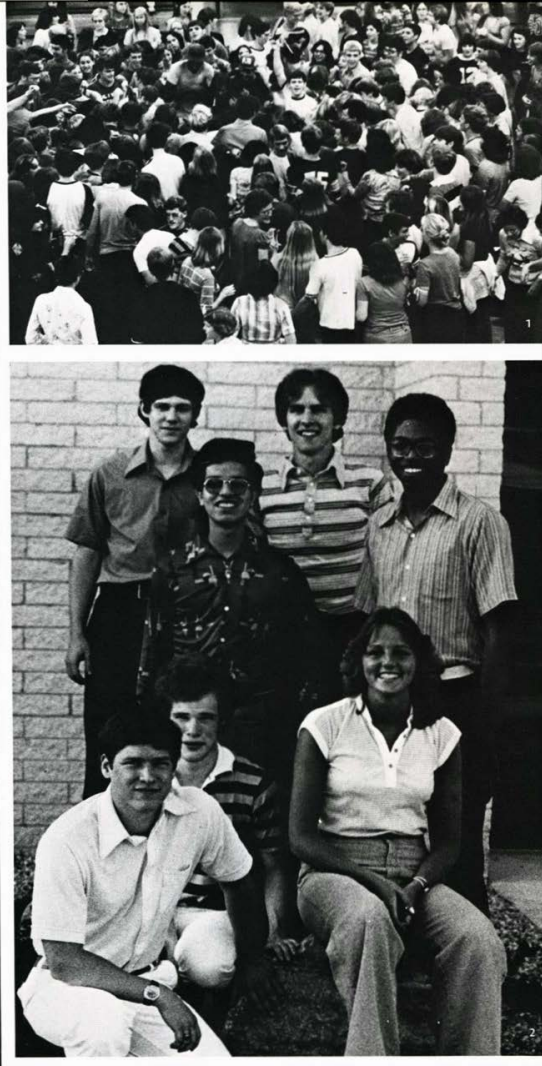
Gary Abbott Ronald Abbott Donald Adamson James Anderson Keith Anderson Mark D. Anderson

Mark L. Anderson Tonya Anderson Chuck Apperson Gary Baden Tom Bailey Anne Barker

Deborah Beacham Laura Bearss Clayton Beck Beth Beckett Suzette Begue Beth Beikert

David Bergandine Dale Betts

Debra Billings

Carleton Birch Tim Bish

Rebecca Blackburn

Joanne Blasdell Debora Bonzo Mary Boston Richard Boswell Melinda Bowman Joann Bradshaw

Lynden Brady Kim Brecher Betsy Bresson Jody Bridges Sue Brooks David Brown

Shirley Brown Linda Birchett

Randy Burk Connie Burleson Robert Butler Tim Butler
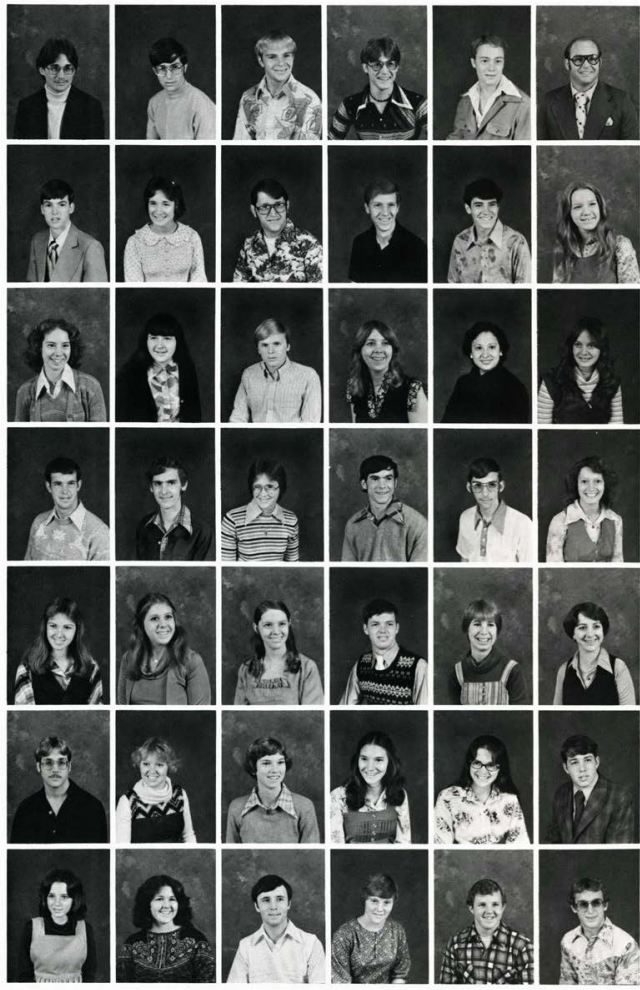
Cliff Davis

Dave Davis

Janet Davis

Linda Davis

Cheryl Deal Jannell Decker

Sandra Decker

Kathy Delp Jeff Dennison

Ted De Shields

Margaret Dewhurst Sandy Domerese

Mark Dresbach James Driscoll Diane Drummer

Donna Dubke John Duff Tim Dunn

Peggy Eagleston Tony Emerson Andrea Entingh

Steve Evans Donna Farmer Lori Faull

Renita Few Tim Filler Cathi Finnemore
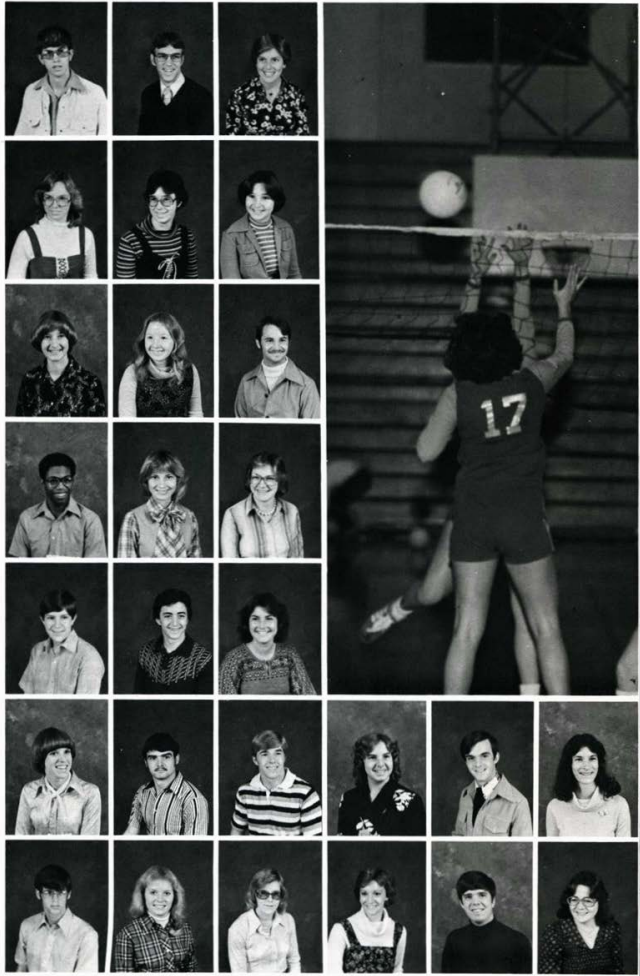
Yvonne Hewitt

Cindy Heinrich

Davie Herne

Ken Herwig

Rhonda Hettinger

Karen Heyburn

Charles Hickey

Rick Hickman

Marjorie Hill

William Hill

Carol Hippard

Tim Hoganson

Becky Holler

Cathryn Holtz

John Horn

Kevin Howard

Mary Howard

James Hoyme

Paula Humphrey Jim Hunt

Julie Hutchins

Dennis Hyde

Yasuaki Inudo

Sherri Isbell

Rhonda Isley

Linda James

Charlene Jarvis

Brian Johnson

Ginny Johnson

Karen Johnson

Mark Johnson

Colette Jones

Rebecca Jones

Rick Jones

Bill Jones

Susan Justice

Pam Kahl

Tammy Kearby

Debbie Kearsley

Steve Keller

Sherry Kennedy

Joel King
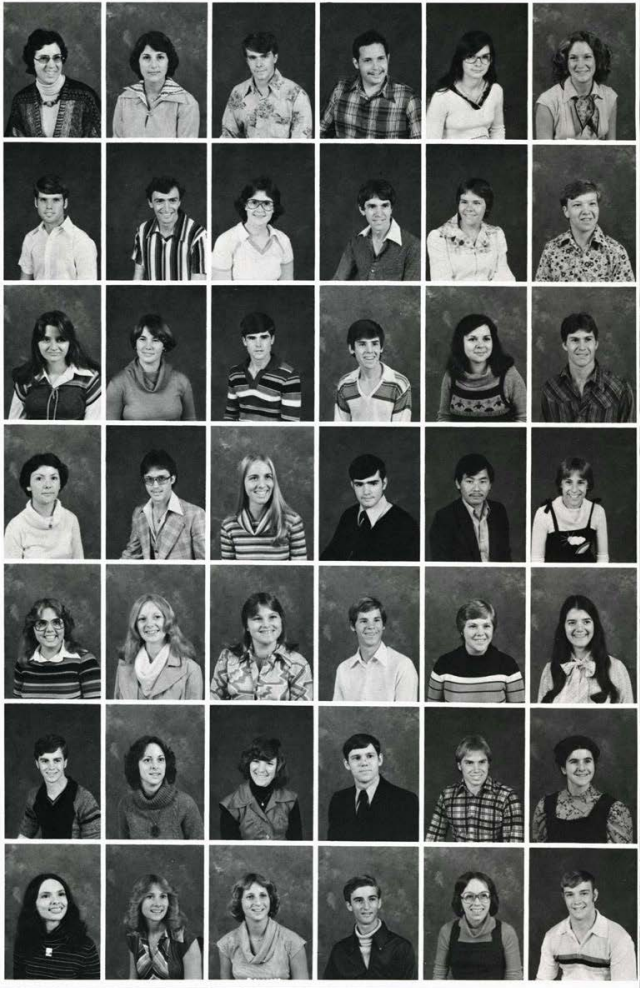
Jacqui Loucks

Deborah Love

John Low

Paul Luce

Phil Ludlow

Wayne Luoma

Jeanne Maitland Belinda Major

Kathy Mallare Kary Mansfield Dan Mantz Brad Mariage Dave Mast Debbie Mast

Rick Matter Barb Mayo Kathleen McCabe Scott McCullough Donna McDaniels David McDougle
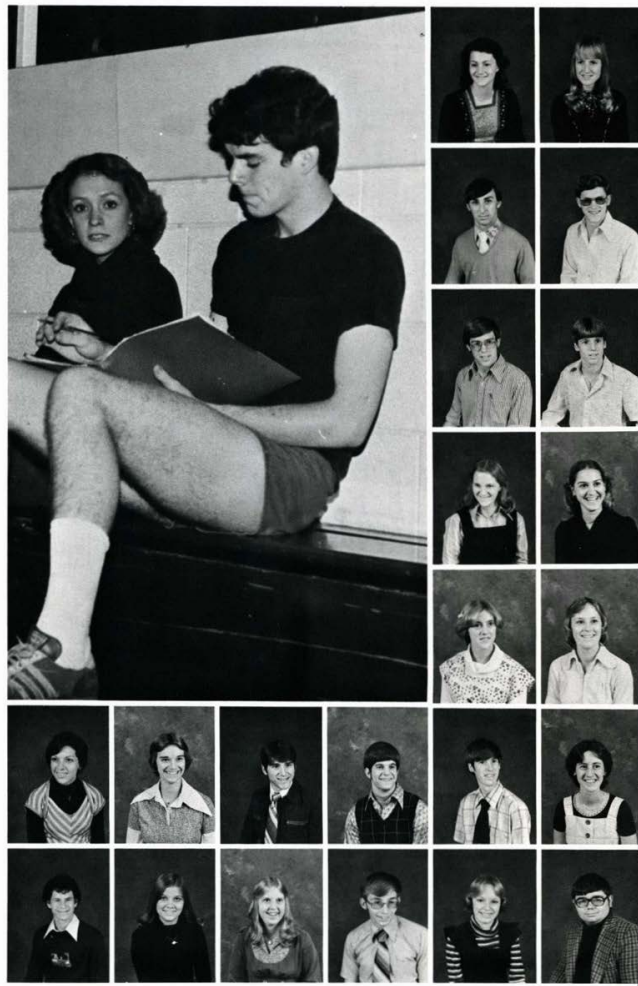
Paul Perry

Ron Phillips

Steve Piazza

Randy Pope

David Price

Carl Prokop

Kathy Putman

Robin Raabe

Lisa Ramsey

Terry Redmond

Debra Reeder

Daniel Reep

Marilynn Reinholdt

Sandy Reynolds

Fred Richer

Don Rickard

Susan Riegle

Kevin Risser

Sharlene Robinson

Deborah Rothaar

Michelle Romango

Tim Ronk

Richelle Rose

John Rosenau

Dan Rowe John Rowland Sandy Runge

Mary Ryberg

Phil Said

Cheryl Samuelson

Julie Santen

Dale Schaechterle

Rachel Scott

Larry Seawell

Kimberly Seefried

Bruce Severs

Beth Schultz

Phil Shanks

Andrew Simpson

Beverly Simpson

Collete Sirka

Susan Shaffer
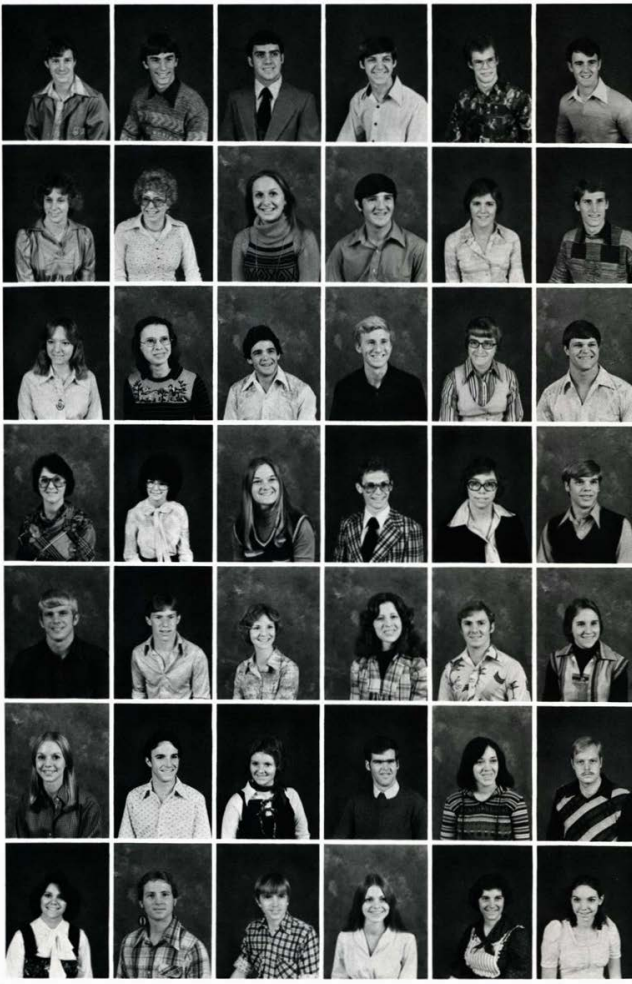
Curt Staller Daniel Standridge David Standridge Steve Stange Mark Staples David Stephenson

Mark Stevens

David Stevenson

Becky Stewart Rhonda Stickelman Phil Stoner Randy Strobridge

Mary Stuenzi David Sugg Cathy Swaney Trudy Tangblade Terry Tate Anne Tawney

Janet Teckmeyer Nancy Tenney Amanda Thomas Mike Tomkins Janis Traphagen Ruthanna Turek
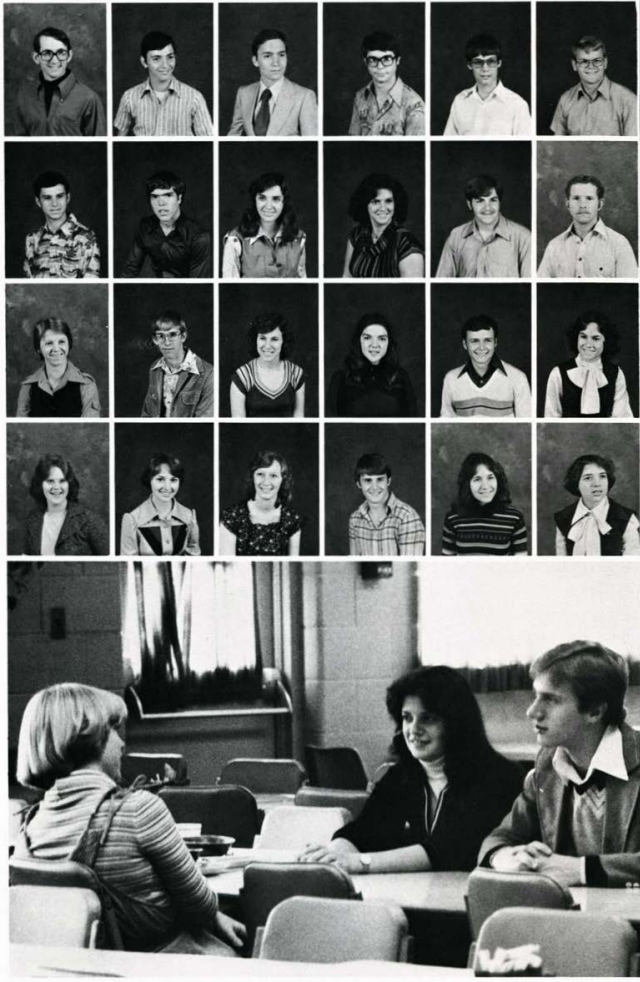


\section{Sophomores Enjoy Active Year}

The Sophomore Class enjoyed an active year. They start by winning the float competition in

the 1977 homecoming

festivities. The class sponsors

the well-attended all-school

Halloween Party which was an

excellent fund-raising tool. A rollerskating party and a bowling party are held near final exams for a study break. The year was

highlighted by a weekend retreat at Shawnee Lodge April 20 and $21,1978$.

1. One of the joys of Christian fellowship is sharing a time of prayer with a friend.

2. "Where has SHE been all of my life?" drools Brad Johnson.

3. SOPHOMORE CLASS OFFICERS: FRONT ROW: Dan Green (Treasurer).

Dawn Jansen (Secretary). Becky Rupe

(Student Senate Alt.), Ginny Decker (Vice-President); BACK ROW: Nate Rehn (Student Senate), Craig Colas

(President), Kim Kauffman (Chaplain). Linda Kuschel (Student Senate) is not pictured.

4. Jane Tedeschi spends a quite evening doing her Theology Survey notebook.

5. "Is it time to get up again?" laments Scott Hinks.
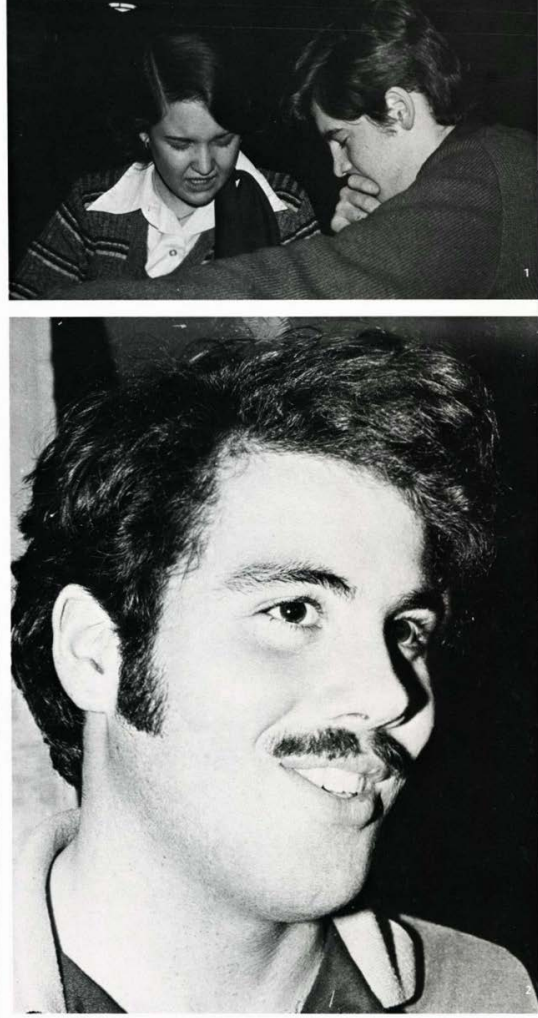


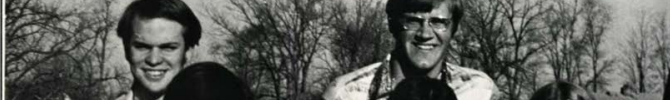
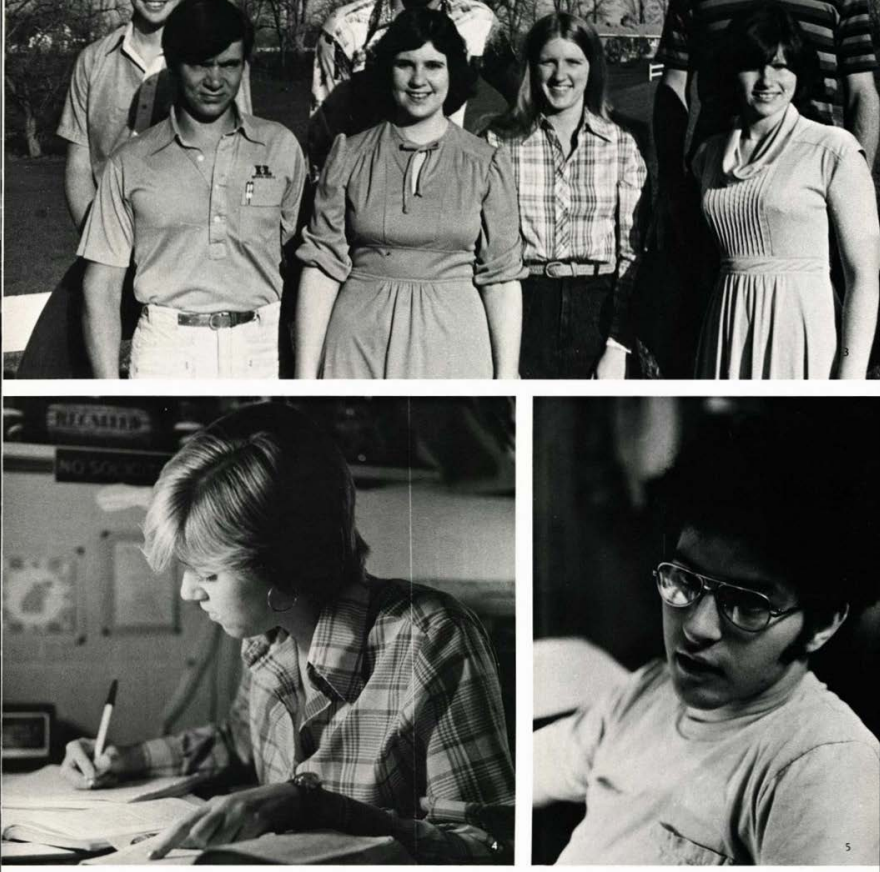
Jeff Acker

Barb Adams

Cathy Adkins

Tom Aitken

Mike Allen

Ken Andrus

Sarah Arthur

Bryce Atkinson

Scott Bahorik

Bill Baldwin

Scott Beight

Dan Betts

James Bocian

Ruth Book

Sandy Bonzo

Robert Bragg

Greg Brace

Mike Bresson

John Briggs

Kathleen Brower

Judy Brown

Kevin Brown

Steve Brown

Laurie Bruening

Paul Buettell

Joyce Butcher

Judi Butcher
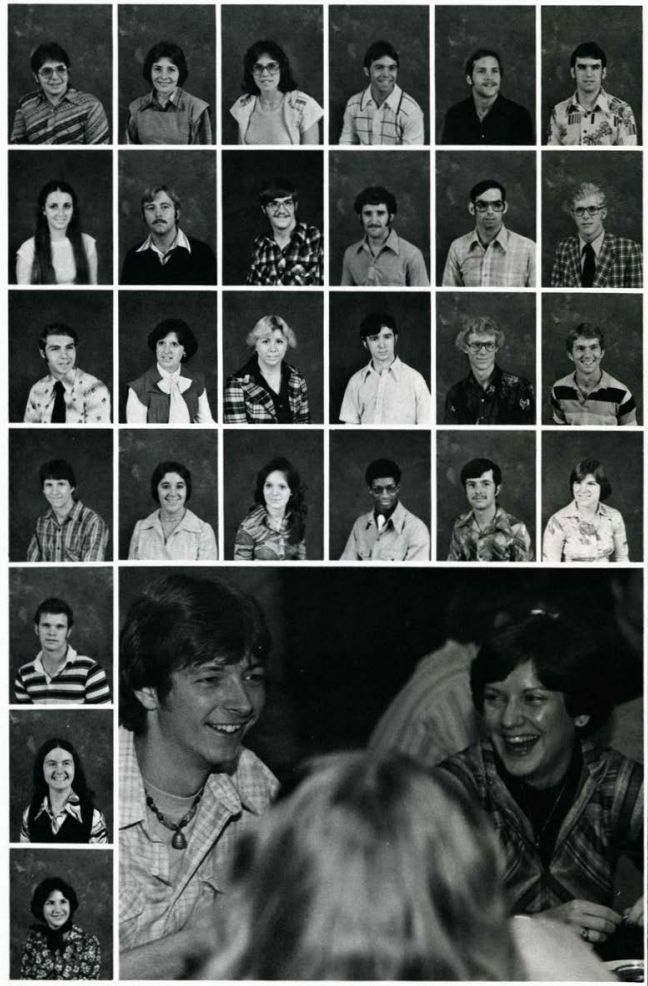
Wayne Godby

Linda Grafton

Faith Grahl

Dan Green

Dann Green

Sharon Green

Fred Greetham

Andy Grenier

Marsha Greve

Wayne Griffiths

Gary Gromack

Cathy Guenther

Pam Hammond Steve Hancock Richard Harley Chuck Hatfield Kevin Hathaway Bill Hayes

Steve Hayes Cathy Heatly Dave Heffernan Kim Henderson Kim Hermansky

Cheryl Herron

Scott Hinks Brenda Hobar Ja Net Hollars

Kim Hosack Brenda Howard Greg Howe

Carolyn Huffman John Humm Cindy Jacobs Brenda James Dawn Jansen Susan Jenkins

Brad Johnson David Johnson Doug Johnson Marilyn Johnson Martha Johnson Cindy Jones
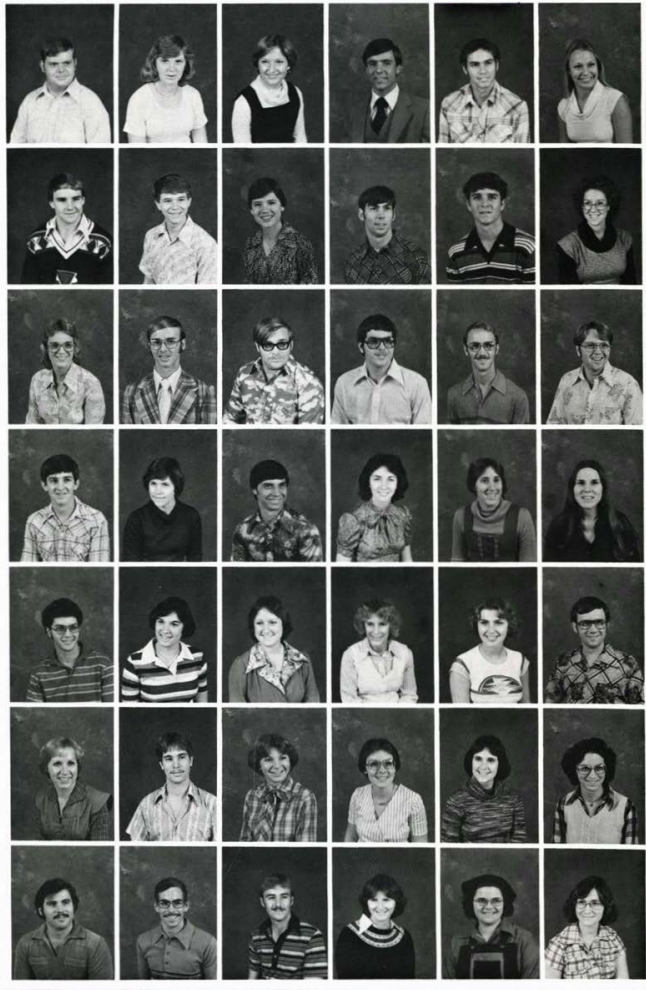
Lori La Haye

Karen Lapp

Dave La Rue

Debora Lawrence Jim Leightenheimer

Sharon Levin

Nancy Lightner Jack Limbaugh Nick Linamen Mark Lones

Nate Longnecker Jim Luce

Norman MacKenzie Julie Marihugh

Cindy Martin Ruth Martin

Kevin Masters Brenda McBride

Terry McClellan Scott McCullough

Mark McFadden Connie McLane
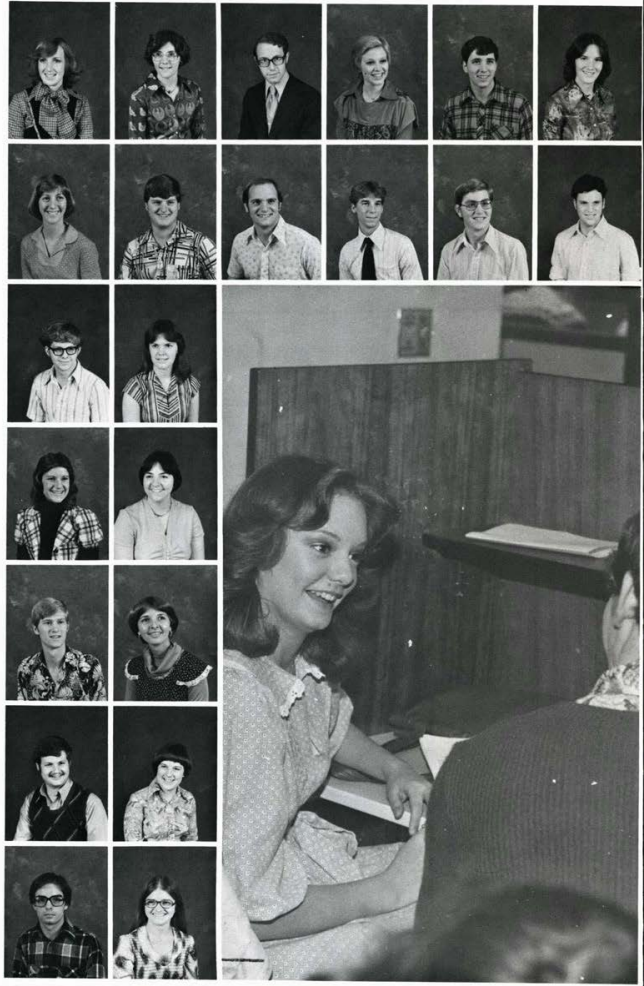

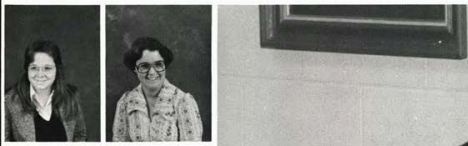

Leah Menninger

Debbie Myers

Patricia Michalski

Roger Michel

Doug Mitchell

Diane Moore

Barry Mosbacker

Debbie Mullet

James Neely

Ruth Northcutt

Judy Ockert

Leslie Oliver

Cindy O'Quinn

Mike O'Quinn

Harvey Ouellette

Cindy Owen
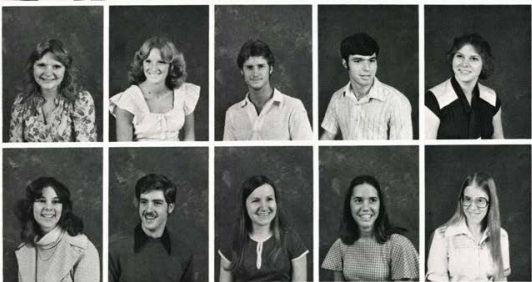

Evelyn Parker

Donna Partridge

Don Parvin

Wendy Patterson

Linda Patton

Kathy Payne 
Karen Payne Kelly Payne Landa Penquite Judy Peterson

Mark Peters Rick Peterson

Steve Petry Glendolyn Phillips Mark Pierce Dan Poole Don Pippin Jocelyn Pruitt

Charles Radcliff Lee Randall Debbie Rapinchuk Debora Reed Nate Rehn Deborah Reid

Darlene Repp Janice Reu Keith Rice Doug Richardson Brian Riggs Ron Rodak
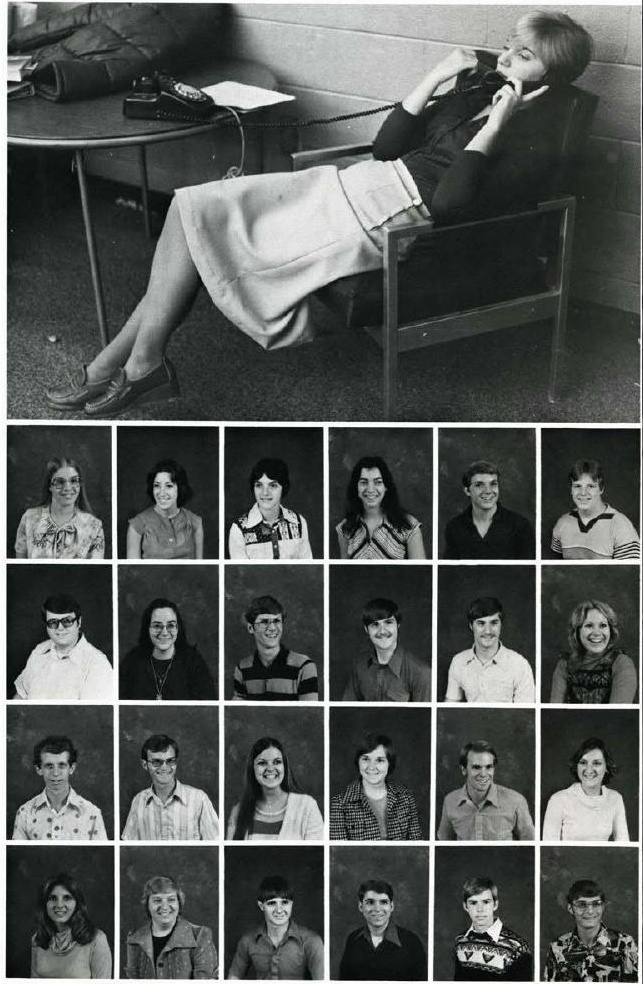
David Stewart Virginia Stone

Charlene Storer Susan Strasler

June Striegel Beth Summerlin

Carol Supplee Cal Swank

Steve Swayze Shawn Taylor

Jane Tedeschi Steve Terlouw Nancy Tillman Darlene Tillson Barry Tindall Stacy Towle

Dana Treese David Treese Kathleen Turner Nancy Unroe Sharalee Utley Marienne Vail
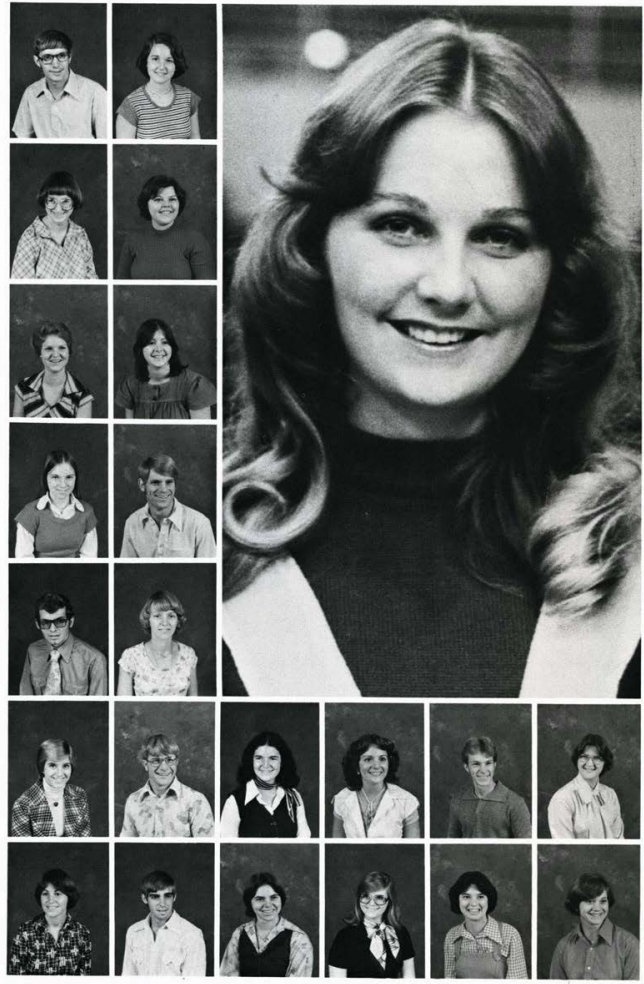


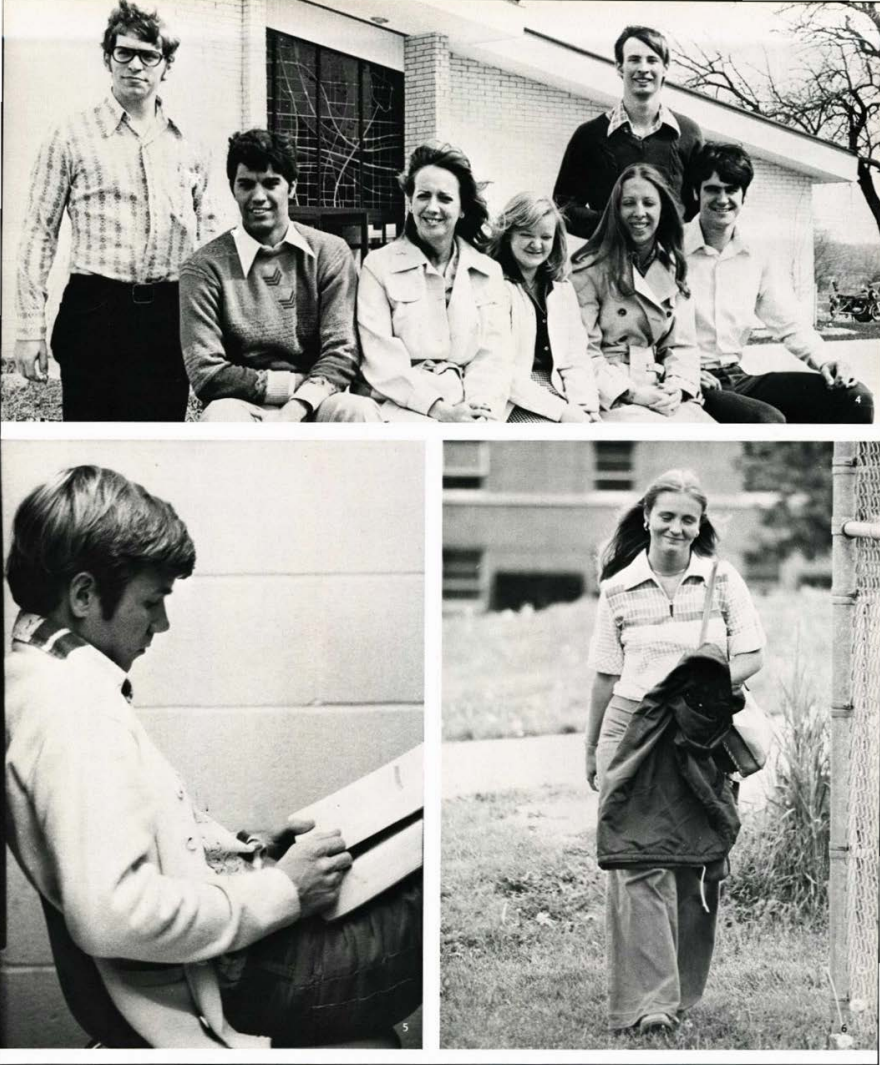


Nancy Abels

Bill Abernathy

John Allen

Crystal Anderson

Kris Anderson

Karin Angel

Paula Arvay

Roger Ashley

Edward Babcock

Pamela Baker

Cindy Banner

James Barrett

Jeffrey Bean

Jodie Beatty

Benny Belleman

Michael Bentley

Ronald Bigelow

Timothy Birk

Debbie Blackburn

Richard Blue

Sue Board

John Bowers

Nelson Brinkman

Terry Broach

Dale Brown

Roberta Brown

Scott Browne

Janet Bubel

Michael Butler

Randy Cagwin

Mark Castellani

August Castellano

Cindy Castle

Robert Cave

Sandra Caylor

Gus Chamberlain

Rachel Chambers

Sondra Champlin

Jeff Conklin

Ruth Cornell

Jeffrey Cowen

Richard Crompton
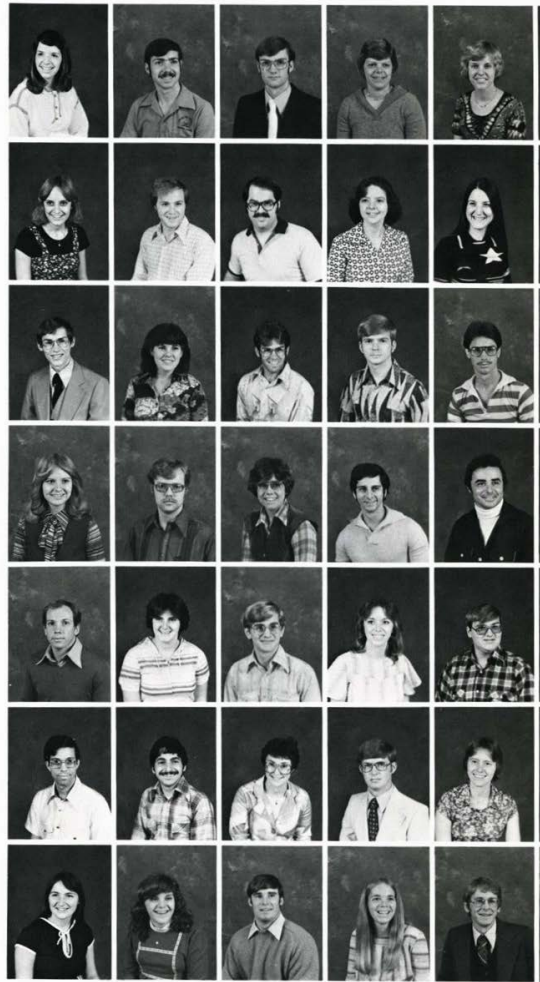
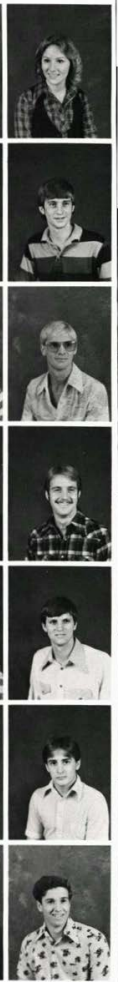


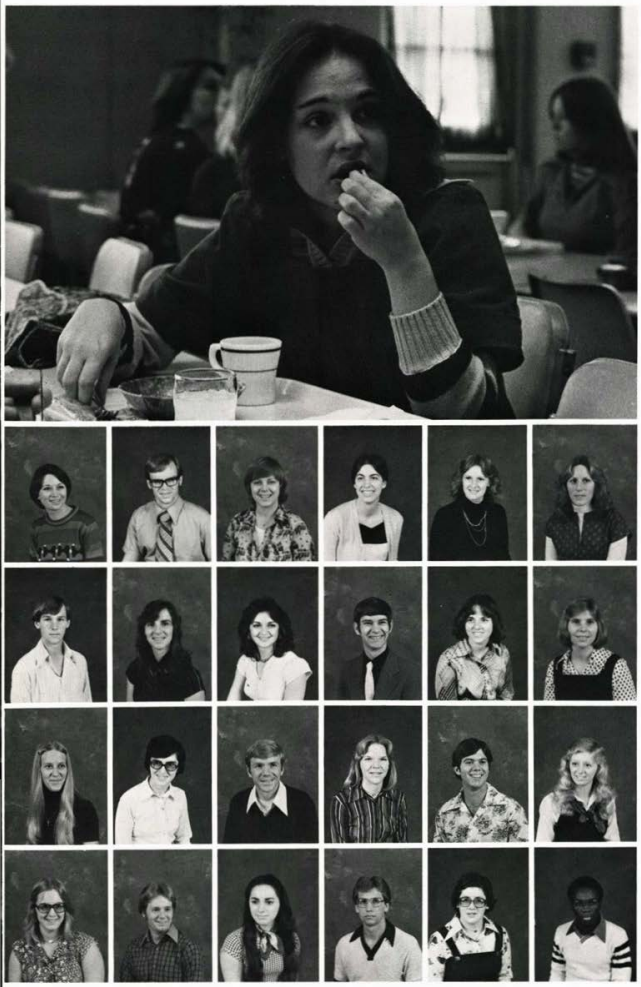

Audrey Cunningham John Dailey Cheryl Danielson Janet Davis Lou Ann De Young Gale Dillsworth

Gordon Donaldson Lynne Donnelly Becky Driscoll David Drozek Karen Duncan Karen Dyer

Lori Earnhart Janet Ebel John Eissens Linda Eissens Dave Ellington Deborah Elmore

Kim Faull

Guy Felmlee Leslie Fields Craig Fisher Paula Flint Jim Footman 
David Francis

Carey Fullmer

Keith Glassey

Dennis Gillenwater

Renee Globig

Terry Gorden
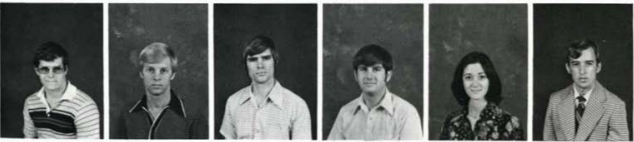

Joy Graham

Gary Gross

David Gregory

Kevin Grier

Dewayne Grooms

Bonnie Guenther

Karen Haga

Cindy Hall

Jane Hansen

Mark Hanson

Robert Hanson

Diana Hare
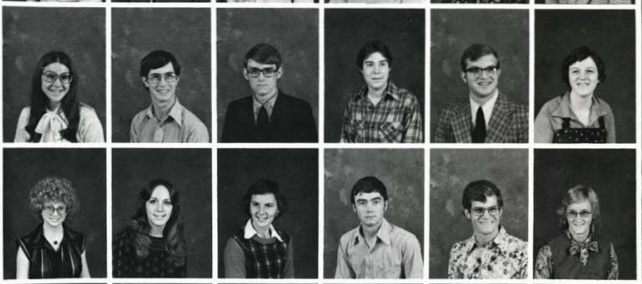

Judy Harkless

Lester Hicks

Mark Highman

Dwain Hill

Gary Hinkle

Donald Huffman
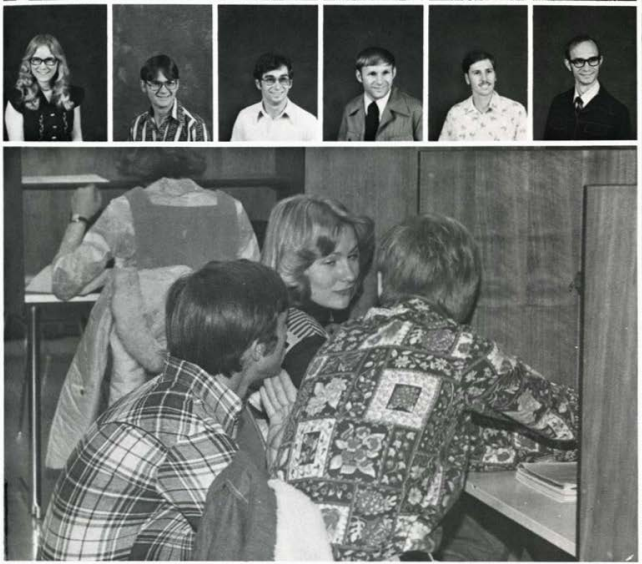

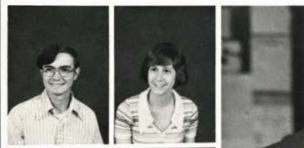

Clyde Hughson

Judy Hugo
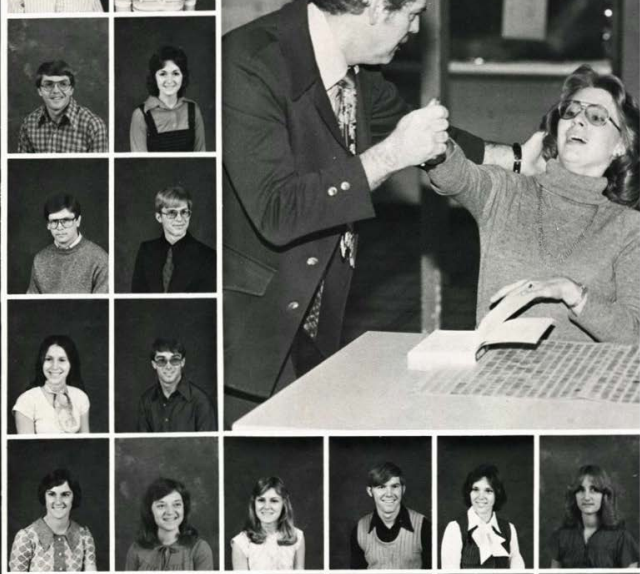

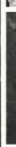
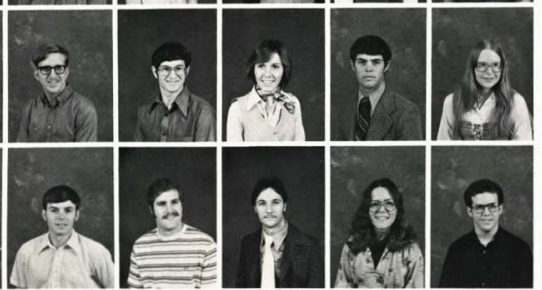

Tom Hutchison Debbie Jackson

John Jackson James Jamison

Francine Jerisk Bryce Johnston

Dianne Jones

Kathy Jones

Sherri Jones

Dan Kaffenbarger

Jan Kauffman

Kathy Kearbey

Denise Kelso

Robert King

Mark Kirby

Desiree Kirk

Jeff Kohns

Mary Knapp

Susan Kuntzelman

Bill Lanphier

Jerry Lantz

Fred Laxton

Jo Leeke

Don Lewis 
Sally Logsdon

Joel Longnecker

Karen Lord

Linda Lufkin

Dave Lynch

Vance Maloney

Donna Marland

Dawn Marvin

Dan Maust

Lisa McClure

Brian Medlock

Ron Medlock

David Messenger Cindy Miller

Craig Miller

Darlene Miller

Phil Miller

Albert Miner

Jane Miner

Delmar Mohler

John Mohler

Rayanne Moore

Alan Morgan

Cheryl Morris

Joyce Morrow

Steve Myers

Lori Neal

Brenda Neally

James Nichols

Dewey Noble

Rachel Norton

Julie Ouellette
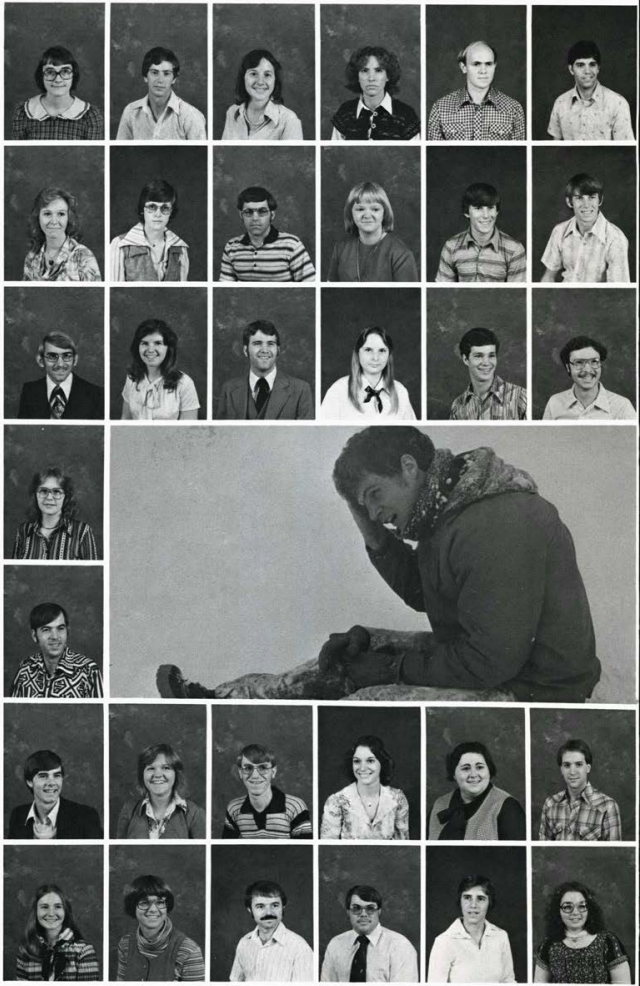
Joan Surso

Deborah Throckmorton

Warren Throckmorton

Anna Tipton

Steve Titus

Debbie Toro

Peggy Van der Hoeven Joel Veldt

Julie Vogel

Tina Wagner

Randy Wagner

Ruth Wagner

Kay Walker

Jearl Ward

Jeff Warix

Mark Warren

Paul Watson

Allen Webber

Dale West

Joanne Westplate

Claudia Whitestine

Greogry Wickham

Karen Wildermuth

Steve Willsey

Scott Wilson

Raphael Wolff

David Woodall

Cindy Wright

Renee Wuebben

Leona Yater

Joy Yhap

Jan Zachary

Suzan Zink

Joyce Cartwright, Sp. James Crawford, Sp.

Glenn Hill, Sp.

Charles Monroe, Sp. Sue Parvin, Sp.

James Peer, Sp.

David Slyby, Sp.

Joyce Wagner, Sp. Valerie Woodring, $\mathrm{Sp}$.
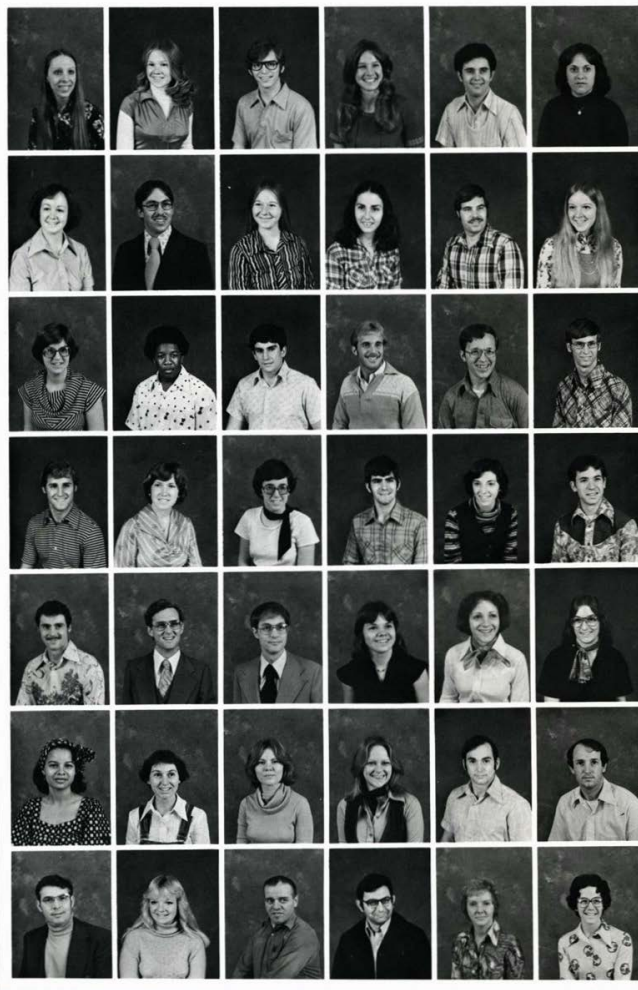


\section{Juniors Included}

In

\section{Who's Who}

Six juniors are selected to be included in the 1977-78 Who's Who Among Students in Universities and Colleges. The basis of their selection is academic performance, cocurricular activities, Christian testimony, and general contribution to campus life. Who's Who certificates are presented during the Honor's Day convocation in May. A volume is published with a compilation of students biographies. A reference and student placement service is provided by the organization. The Student Affairs Committee, Personnel Assistants, and leaders of campus organizations make the annual selections.

1. DALE WEST

Business Administration

2. PHILIP MILLER

Pre-Seminary

3. JOHN POTTER

Mathematics

4. JOAN SURSO

Chemistry

5. CRAIG MILLER

Pre-Seminary

6. BILL ABERNATHY

Pre-Seminary

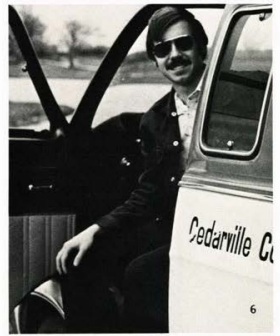




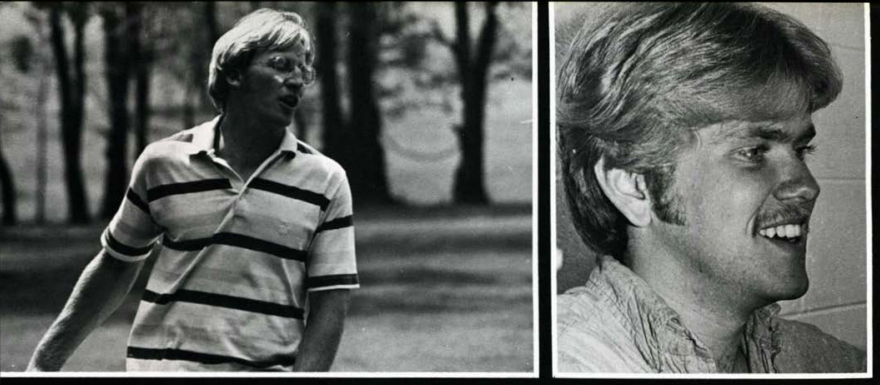


Nanette Addison

Elementary Education

Cleveland, Ohio

Cheryl Alspaugh

Elementary Education

Cedarville, Ohio

Tim Altimus

Business Administration

Olmsted Falls, Ohio

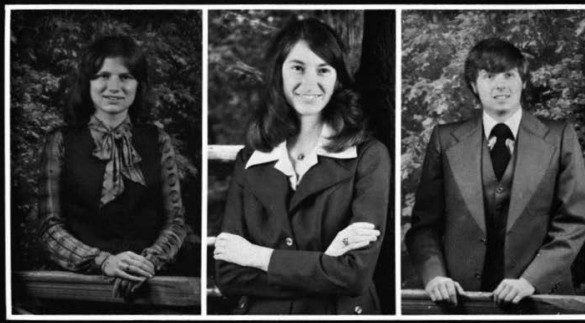

ohn Alvey

Speech

Marion, Indiana

Kent Amstutz

Biology

Cherry Hill, New Jersey

Janice Anderson

Elementary Education

Brattleboro, Vermont

Joyce Anderson

Behavioral Science/Psychology

Fort Wayne, Indiana

Kim Anderson

Elementary Education Jersey Shore, Pennsylvania

Scott Anderson

Political Science

Bellefontaine, Ohio
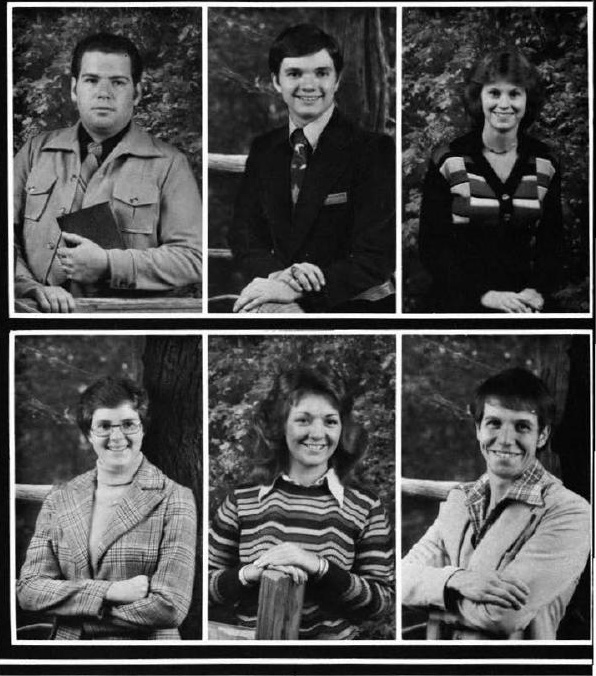
Timothy Bos

Political Science

Grandville, Michigan

Coessa Brown Psychology/Behavioral Science

Coshocton, Ohio

Cathy Bunton

Physical Education

Clarkston. Michigan

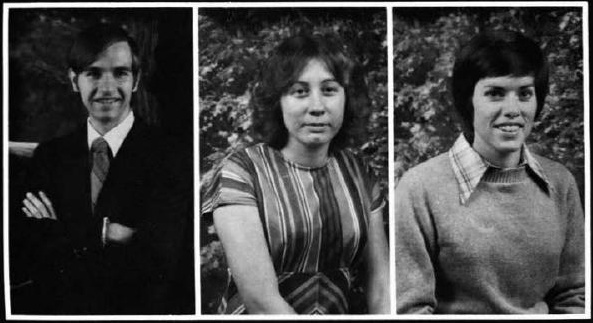

Vicki Burleson

Bible

Bidwell, Ohio

David Burns

Pre-Seminary

Conneautville, Pennsylvania

Dennis Burns

Bible

Cedarville, Ohio

Gloria Bushong

Bible

Kenton, Ohio

Randall Campbell Speech

Albright, West Virginia

Steven G. Campbell

Business Administration Holden, Massachusetts
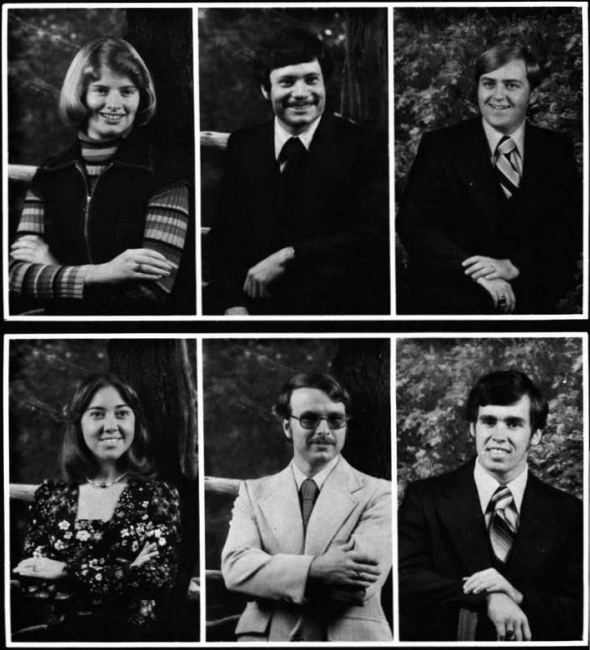
Bruce Compton

Business Administration

Hopewell, New Jersey

Diane Conrad

Speech Education

Columbia Station, Ohio

Mark Cowell

Pre-Seminary

Berea, Ohio

Judie Cross

Physical Education

Houston, Texas

Michael Cuffman

Speech

Bucyrus, Ohio

Pam Dalby

IDS-Philosophy

Mattoon, Illinois

John Dannenburg

IDS-Philosophy Jenison, Michigan

Jeffrey Davis

Broadcasting

Cedarville, Ohio

Linda M. Davis

Elementary Education

Cincinnatus. New York
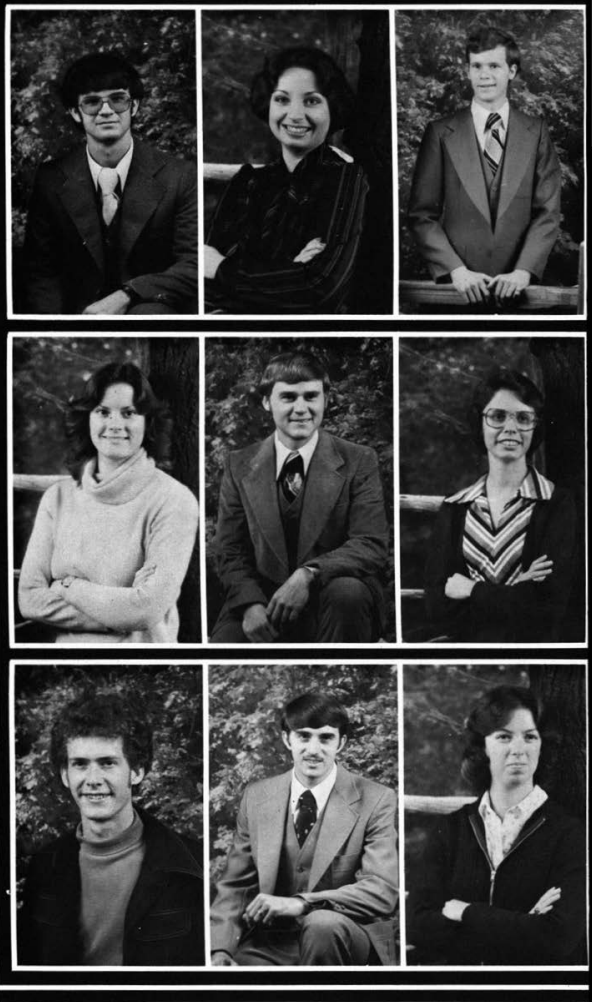

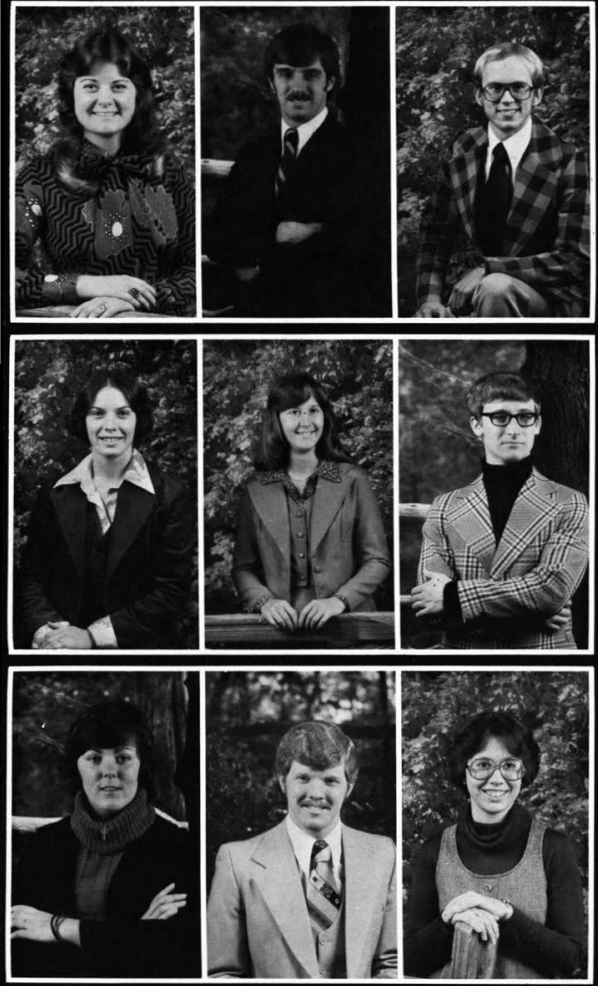

Sandy Dawson

Psychology

Royal Oak, Michigan

Dan Dedic

Business Administration

Alton, Illinois

Ed De Lange

Biology

Bondurant, lowa

Michele Park De Lange

Physical Education

Hazel Park. Michigan

Diane De Nicola

Music Education

Rochester, New York

David Denny

Behavioral Science

Milford, New York

Nancy Drake

English Ed./History Ed.

Bethesda, Ohio

Daniel Dunn

Pre-Seminary

Buffalo Grove, Illinois

Rosalie Eaton

Music Education

Findlay, Ohio 
Paul Edwards

IDS-History

Melbourne, Vic., Australia

Mary Emery Elementary Education Willowick, Ohio

Judy Erikson Elementary Education Jamestown, New York

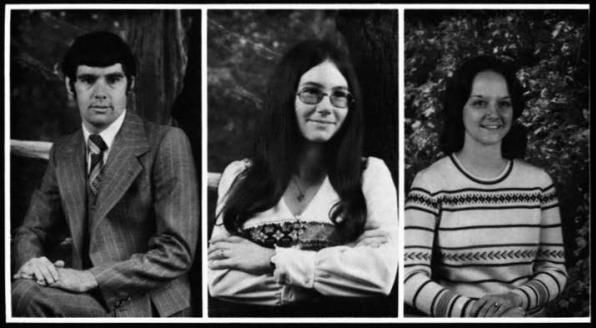

Linda Ernst

Anaheim, California

Ken Erny

Social Science

Burlington, New Jersey

Vernon Esham

Comprehensive Bible Salisbury, Maryland

Laura Everett

Elementary Education Osceola, Indiana

Deborah R. Festag English

Elmira, New York

Bryan Few

Broadcasting

Chippewa Lake. Ohio

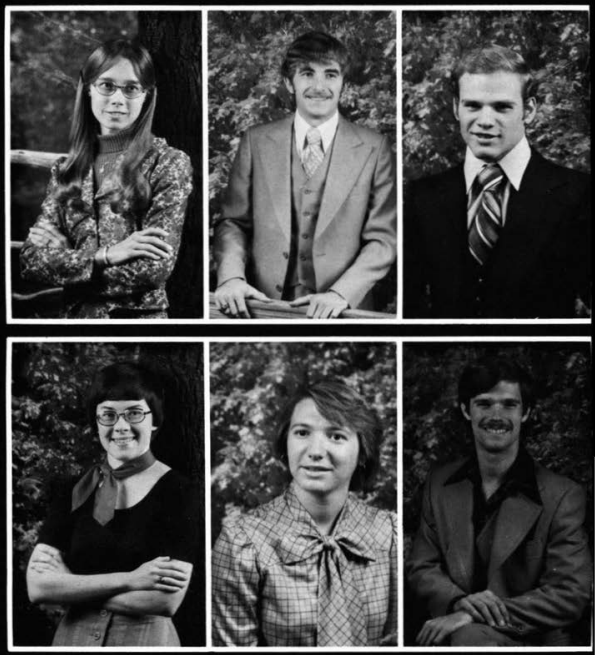




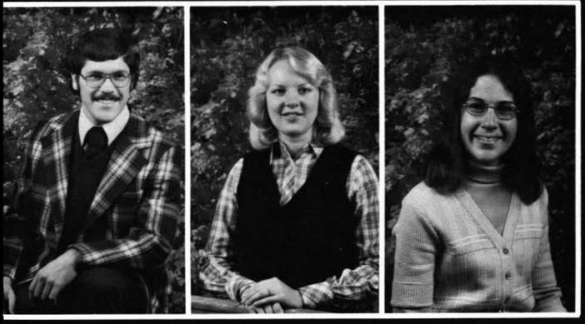

Dennis Few

Broadcasting

Medina, Ohio

Mary Forsten

IDS-Psychology

Lapeer, Michigan

Kimerly Gall

Physical Education

Britton. Michigan

Peter Gardner

Biology

Topsham, Maine

Denise Gawthrop

Psychology

Fairmont, West Virginia

David Gilbert

Comprehensive Bible

Xenia, Ohio

William Gilmour

Biology

Niles, Ohio

David J. Glenney

Bible

Fairfax, Virginia

Sandra Glenney

Comprehensive Bible

Carthage. New York 
Wayne Godby

Bible

Cedarville, Ohio

Linda Gradish

Elementary Education

Amherst, Ohio

Karen Gray

Elementary Education

Winterset, Ohio

Carole Green

Elementary Education

Piketon, Ohio

Kathy Green

Elementary Education

Cedarville, Ohio

Rebecca Hamer

English

Huron, Ohio

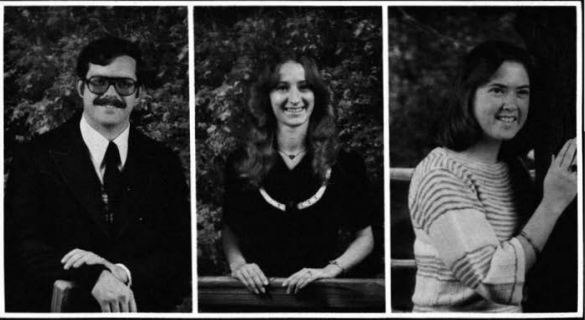

Kurt Harding

Chemistry

Marathon, New York

Carla Hargis

Elementary Education

New London, Ohio

Daniel Harkleroad

Behavioral Science Education

Brentwood, Maryland
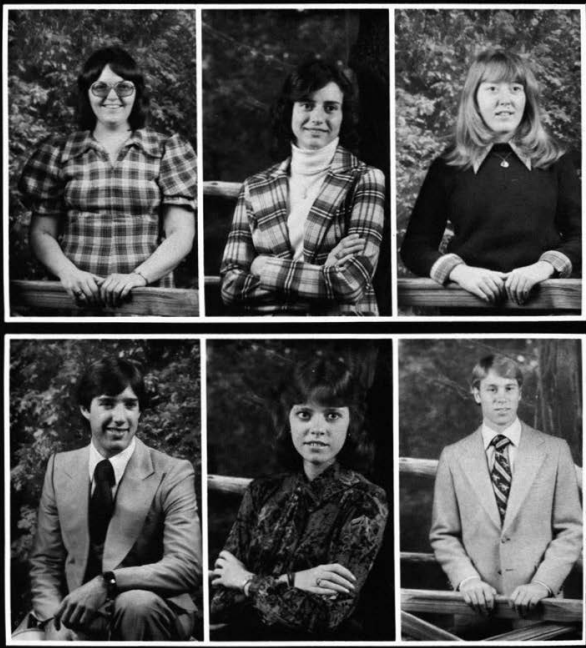

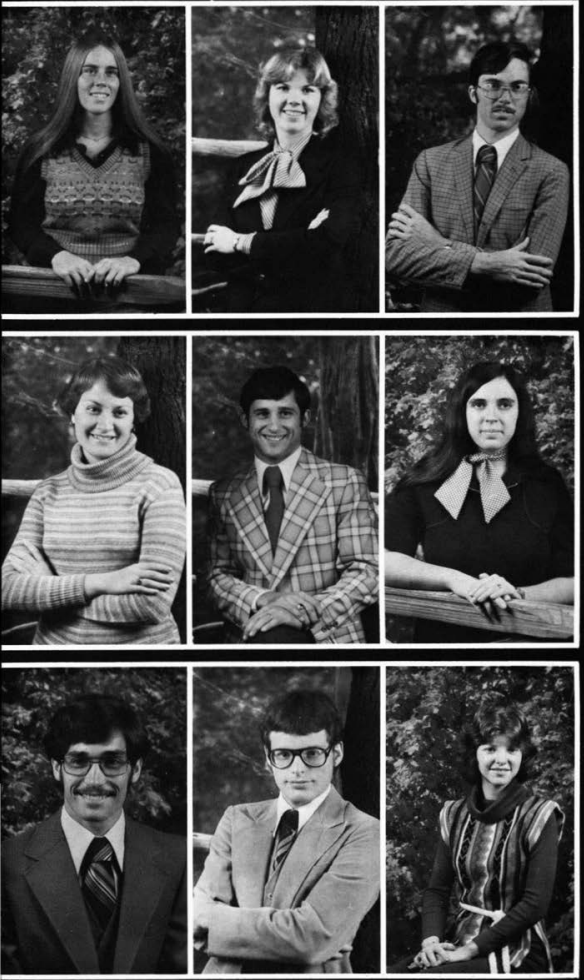

Mary Harris

Chemistry

Warminster, Pennsylvania

Pamela Harrison

Psychology

Lincoln Park, Michigan

Brooks Hartzell

Pre-Seminary

Miamisburg, Ohio

Debra Hattenfield

Elementary Education

Columbus, Ohio

Barry Heagy

Bible

Cedarville, Ohio

Ann Henning

Psychology

Bellefontaine, Ohio

Bruce Henslin

Business Administration

Dodge Center, Minnesota

Daniel Hicks

Biology

Cedarburg. Wisconsin

Elaine Hill

Biology

Dayton, Ohio 
Dennis Hinks

Pre-Seminary

Gettysburg. Pennsylvania

Judith Hinks

Chemistry

Gettysburg, Pennsylvania

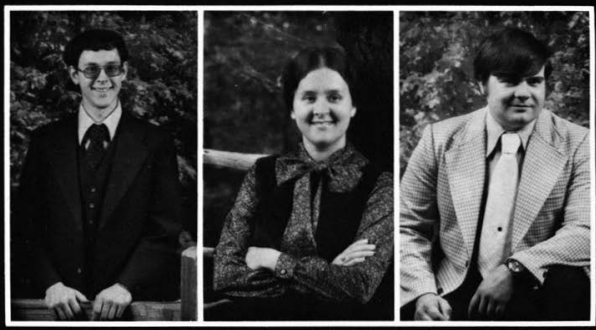

Patricia Holmes

Physical Education

North Jackson, Ohio

Elementary Education

Simcoe, Ontario, Canada

Debbie Howard

History

Lebanon, Indiana

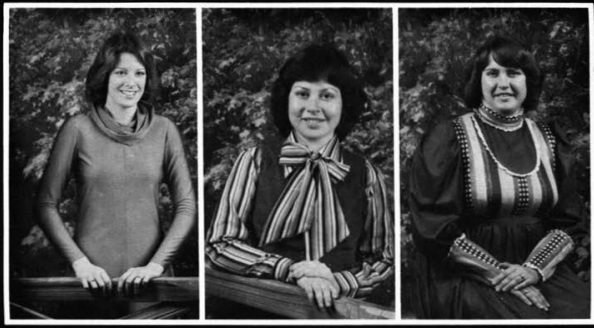

Steve Hoy

English Education

Halifax, Pennsylvania

Terrell Hudson

Comprehensive Bible

West Carrollton, Ohio

Leslie Hufziger

Business Administration

Columbus, Ohio

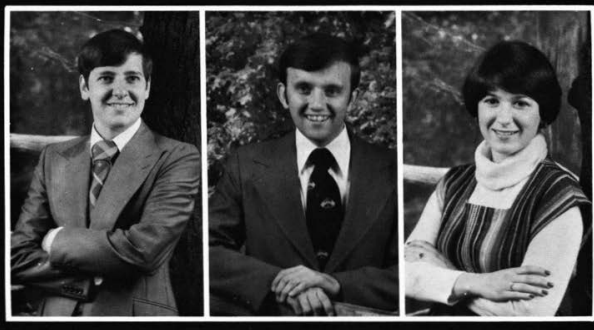



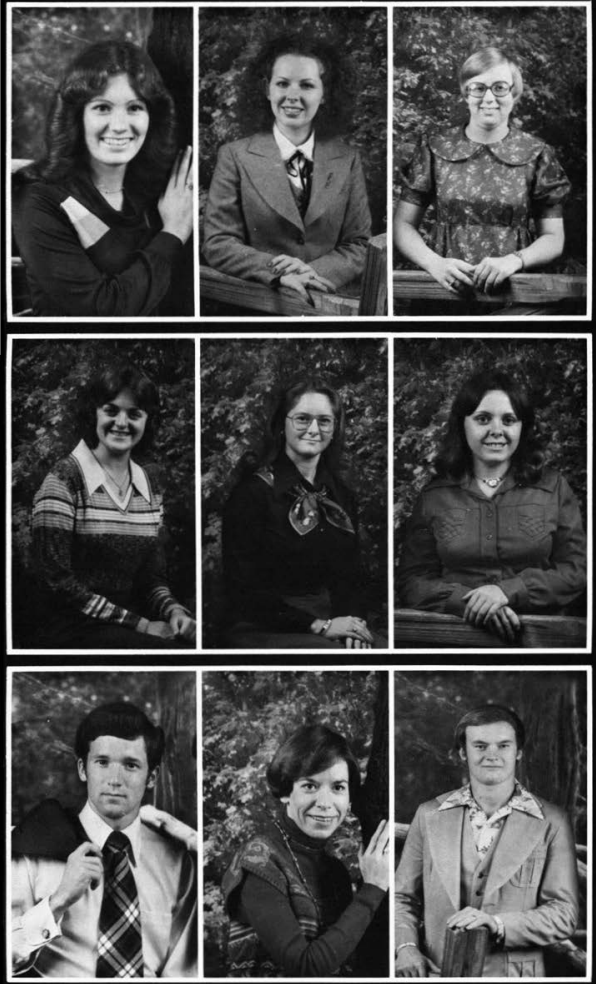

Mary Humbert

Elementary Education Shiloh, Ohio

Heidi Humble

Broadcasting

West Liberty. Ohio

Denise Hunn

Elementary Education

New Lebanon, Ohio

Dee Jackson

Speech

Carroll, Ohio

Catherine James

Elementary Education

Lakewood, New York

Deborah James

English

Tokyo, Japan

David Jarvis

Business Administration Rohnert Park, California

Sandra Johnson

Elementary Education

Cincinnati, Ohio

David Joseph

Physical Education

Kettering, Ohio 


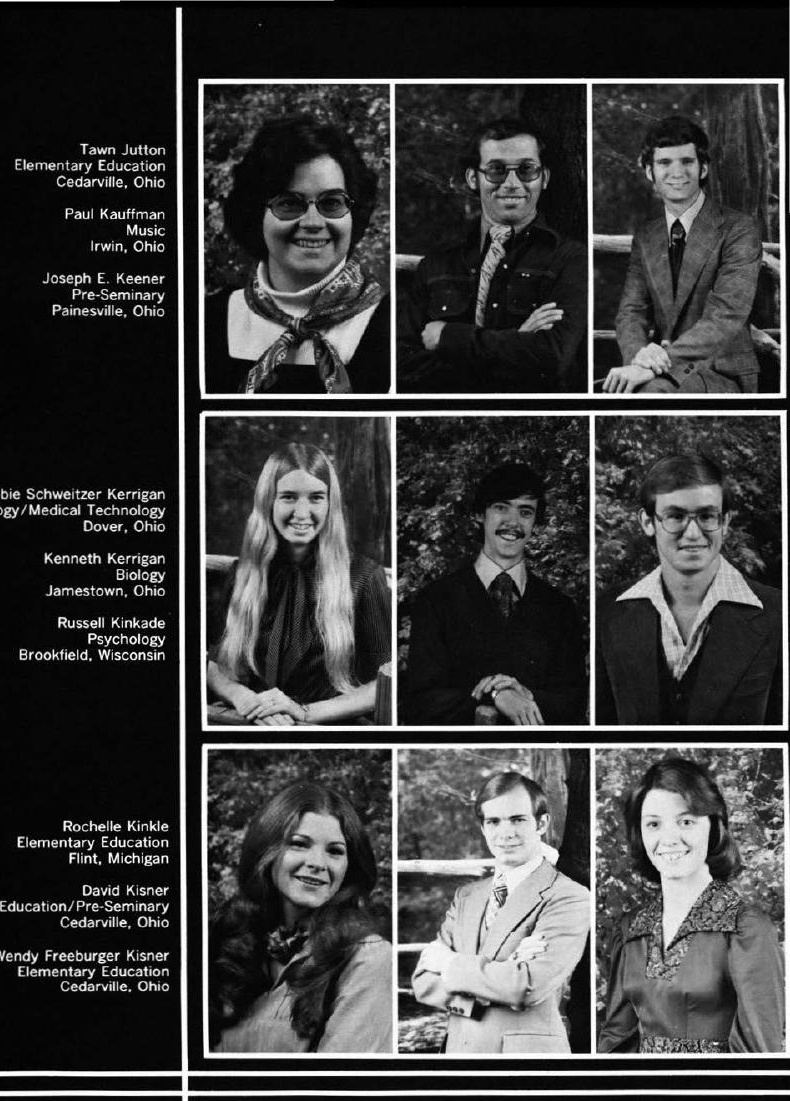

Debbie Schweitzer Kerrigan Biology/Medical Technology Dover, Ohio

Kenneth Kerrigan Biology

Russell Kinkade

Psychology

tary Education

int, Michigan

History Education /Pre-Seminary Cedarville, Ohio

Wendy Freeburger Kisner Cedarville. Ohio 
Kathleen Lord Music Ed./English Ed. Endwell, New York

Joyce Lucht Behavioral Science Windsor, Ohio

Richard Luedeke

Music Education New Bremen, Ohio

\section{Vernon Lutman \\ Psychology \\ Cumberland. Maryland}

Thomas Lutz

Psychology/Behavioral Science

Lima, Ohio

David Lyons

IDS-Bible

Perry, Ohio

Andrea MacDermaid

Physical Education West Bloomfield, Michigan

Margot Martens Mathematics Education Stanley, New York

Lydia Mason Speech Proctorville, Ohio
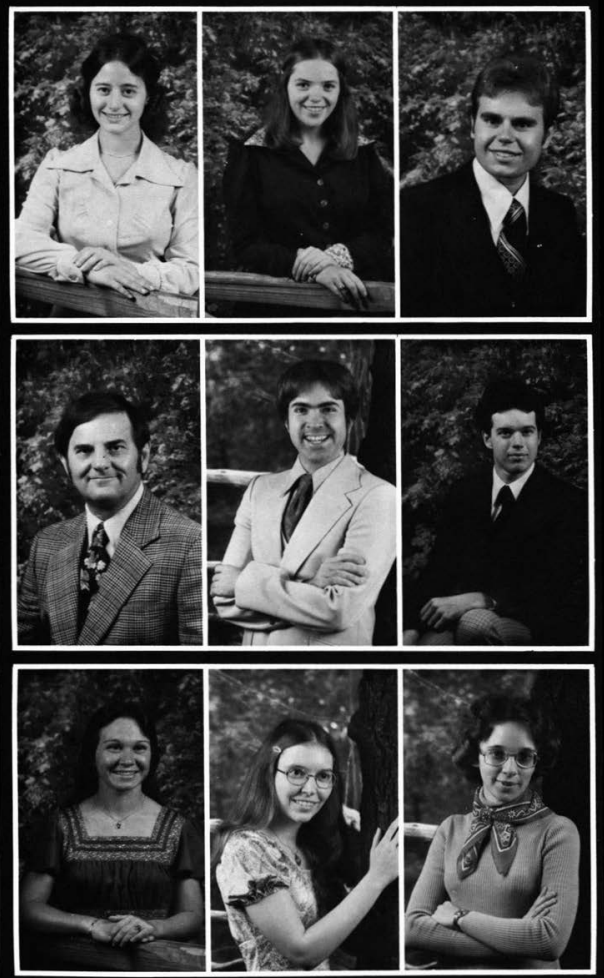
Brian N. Miller

IDS-Philosophy

Horseheads, New York

Stephen Miller Biology

Binghamton, New York

Thomas Mohler Biology Litchfield, Ohio

Pam Monday Behavioral Science Findlay, Ohio

Charles S. Monroe Behavioral Science Springfield, Ohio

H. Dianne Monts Broadcasting Decatur, Illinois

Rebecca Myers Behavioral Science Grand Rapids, Michigan

Jack Nace Psychology

Perkasie, Pennsylvania

Keith Namy Behavioral Science Brownsburg, Indiana
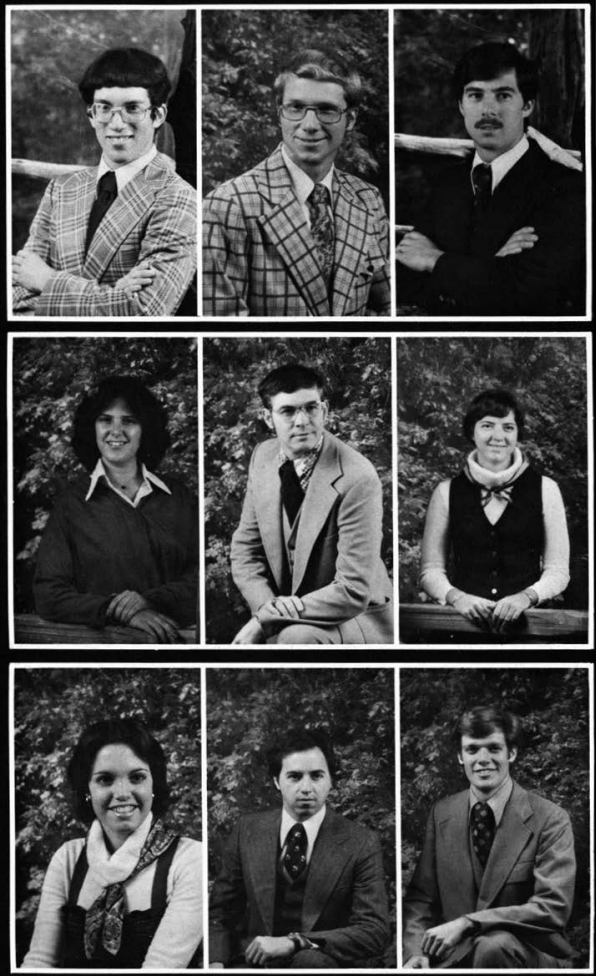
Sally Pearce

Elementary Education

Amherst, Ohio

Roxanne Perry Elementary Education Wyoming, New York

Susan Perry

Elementary Education

Elkhart, Indiana

Mark Peterson

Behavioral Science

Flint, Michigan

Jeanne Pippin Music

Fort Wayne, Indiana

Steve Poling

Mathematics

Kent City. Michigan
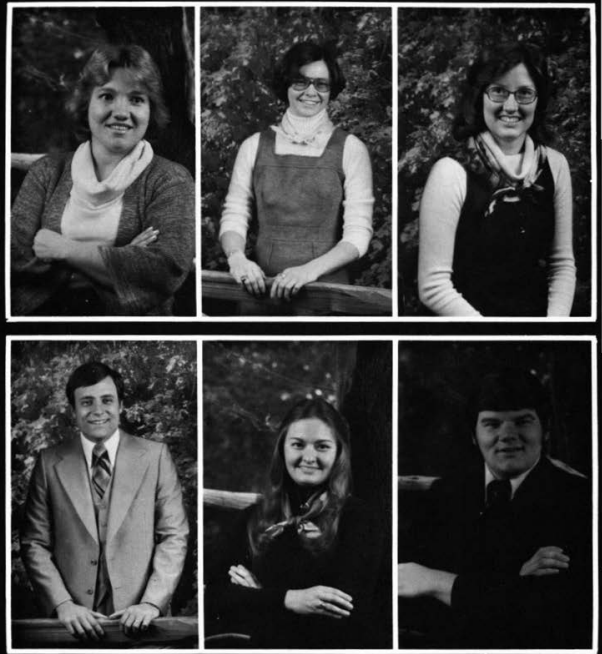

Jon Raber

Music Education Cedarville, Ohio

Michael Rae Social Science

Eastlake, Ohio

Deborah Ransom

Speech

Bucyrus, Ohio

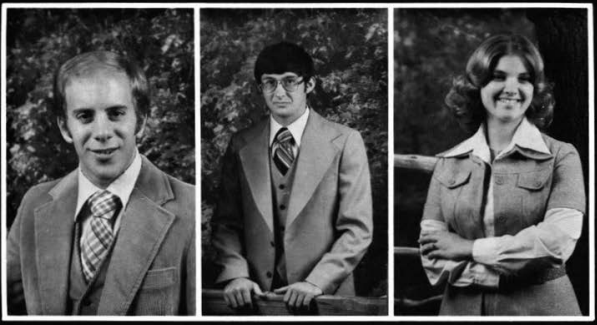


Rhonda Rogers Elementary Education

Byesville, Ohio

Cathy Rohm
Elementary Education
Muncy, Pennsylvania
William Roloff
Bible
Canton, Ohio


Amy Ross
Biology
David Rossi
Pre-Seminary
Cedarville, Ohio
Wesley Rowe
Physical Education
Portsmouth, Ohio
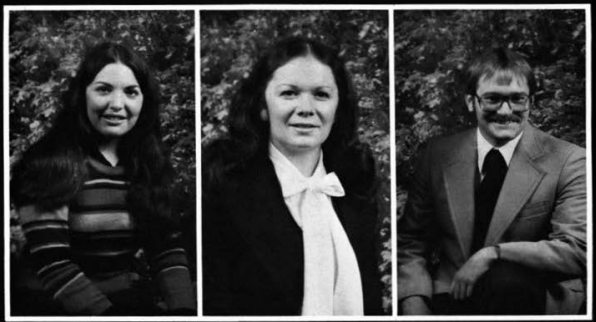

Timothy Rowland

Pre-Seminary

Greenwood, Indiana

Donna Luoma Santerre Biology New Ipswich, New Hampshire

Elizabeth Schierwagen

Behavioral Science

Pearl River, New York

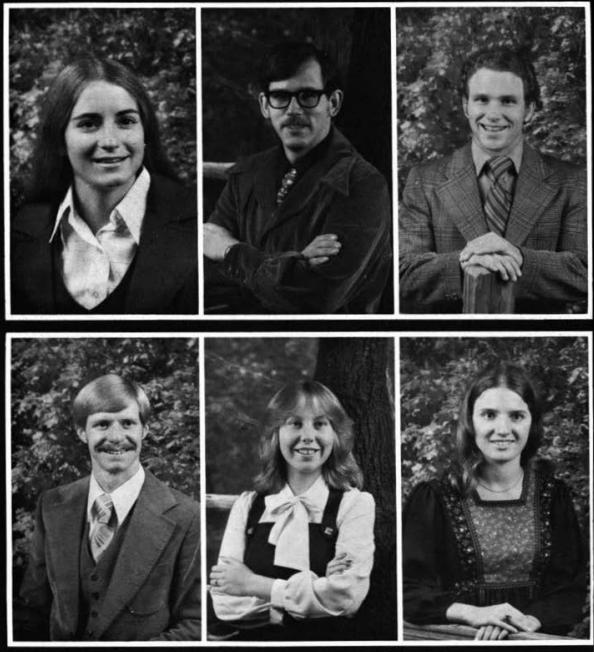


Lynette Stauffer

Music

Montrose, Michigan

Dennis Sticke

Business Administration

Elkhart, Indiana

David Stoner

Pre-Seminary

Valparaiso, Indiana

Timothy Stoner

Pre-Seminary

Grand Rapids, Michigan

Deborah Storch

Music

Joliet, Illinois

Janie Street

Music

Cedarville, Ohio

Rebecca Street

English Education

Caldwell, Ohio

Marla Streitmatter

Business Administration

Rensselaer, Indiana

Dwight Strickland

Pre-Seminary

Cedarville, Ohio
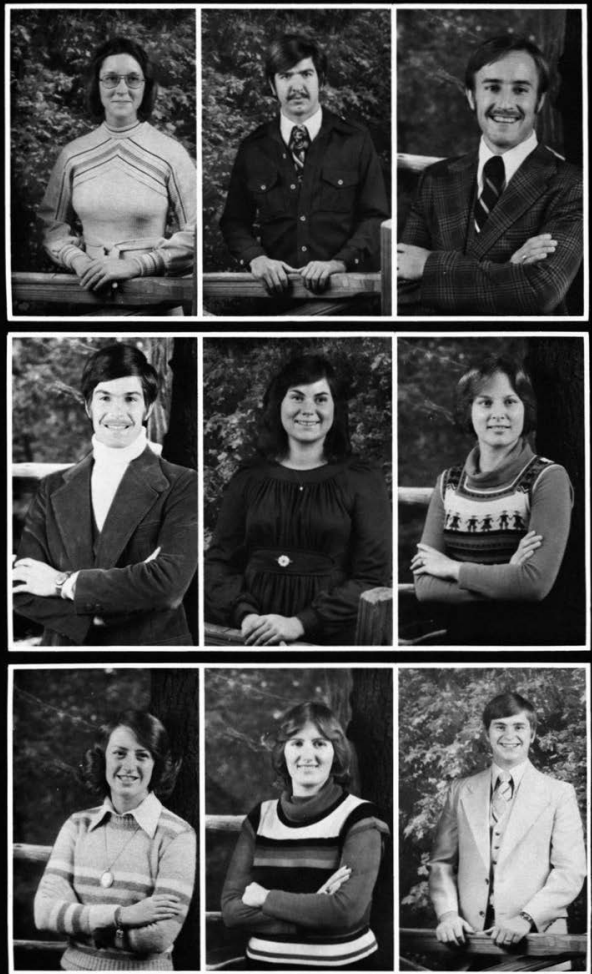


Rebekah Trittipoe
Biology
Columbus, Ohio
Larry Twigg
Mathematics Education
Indianapolis, Indiana
Rodney Uzzel
Bible
Cedarville, Ohio

Glenna Wagner
Music Education
Menomonee Falls, Wisconsin

Pam Waldo

Elementary Education

Elyria, Ohio

Perry Washburn

Biology

Worthington, Pennsylvania

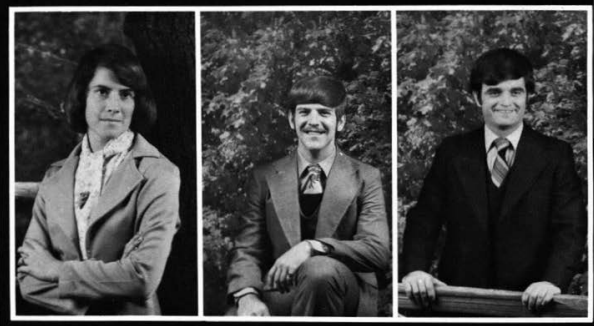

Cherie Watts

Elementary Education Monogahela, Pennsylvania

Barry Weller

Psychology

Callahan, Florida

Lydia West

Speech Ed./English Ed. Wilmington, Illinois

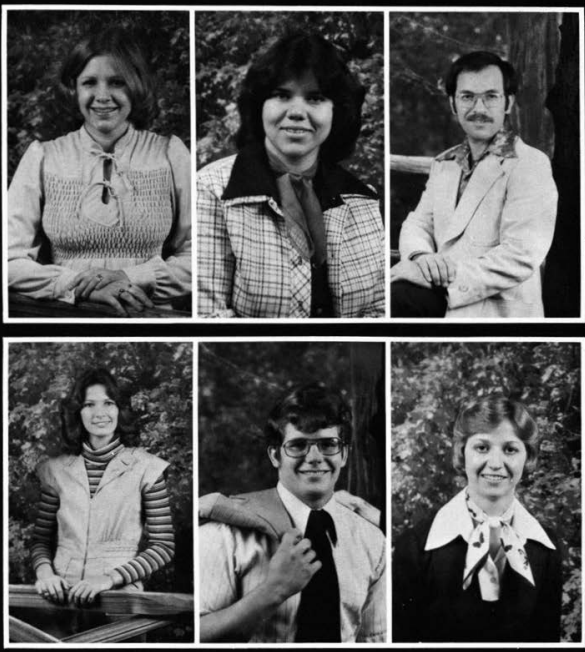


Rhonda Young Elementary Education Bloomfield, Ohio

Young, Richard Pre-Seminary Valley City. Ohio

Debby Zaller Psychology/Behavoiral Science Mayfield Village, Ohio

Carl Zelonis Psychology/Behavioral Science Canton, Ohio

Becky Ziemer Physical Education New Philadelphia, Ohio
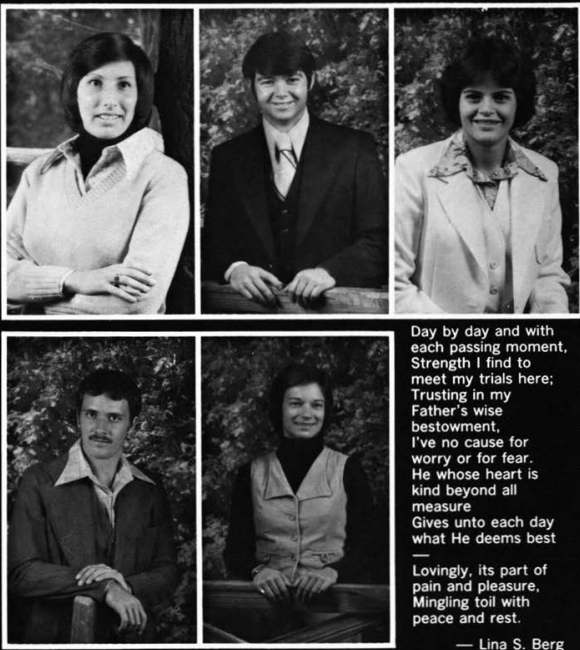

Day by day and with each passing moment, Strength $I$ find to meet my trials here; Trusting in my Father's wise bestowment, I've no cause for worry or for fear. He whose heart is kind beyond all measure

Gives unto each day what $\mathrm{He}$ deems best

Lovingly, its part of pain and pleasure, Mingling toil with peace and rest.

- Lina S. Berg

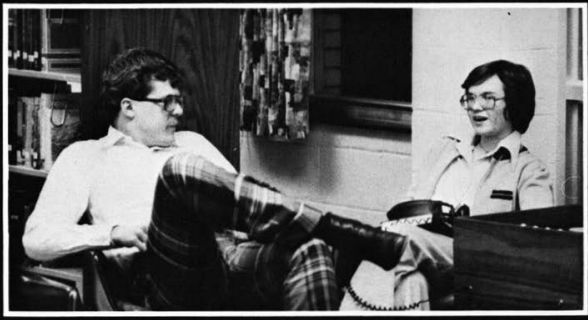



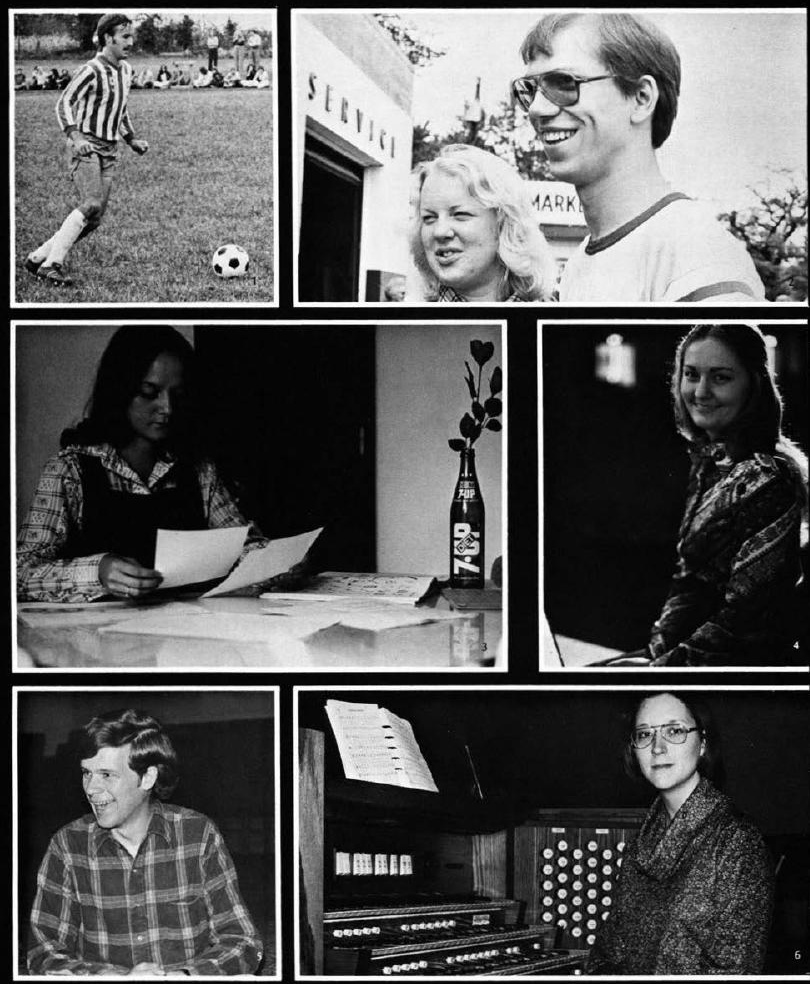


\section{Eighty-Second Commencement Honors Dr. Jeremiah And Graduates}

Cedarville College confers 223 baccalaureate degrees at the Eighty-Second Commencement on June 3, 1978 in the newlynamed James $\mathbf{T}$. Jeremiah

Chapel. The Commencement begins with the traditiona academic processional from the Gym-Student Center to the Chapel. President James T. Jeremiah introduces President-

Elect Paul Dixon. Mr. Dixon presents a response that includes the desire to build upon Dr. Jeremiah's solid foundation. Senior Class President Martin C. Shaw, Jr. presents Dr. Jeremiah with a class gift of two paddle boats for Cedar Lake.

1. Victoria Clark lelads the commencement processional. 2. Dr. Jeremiah introduces PresidentElect Paul Dixon.

3. Mr. Dixon presents a response that includes the desire to build upon $\mathrm{Dr}$. Jeremiah's solid foundation.

4. The candidates for graduation are presented to President Jeremiah by Academic Dean Clifford Johnson. 5. Debbie Kerrigan receives the Clifford R. Maddox Memorial Award for attaining the highest average in the Undergraduate Record Examination Field tests.

6. Dr. Jeremiah greets Lydia West with the traditional graduation handshake as she accepts her diploma. 7. Mr. J. Dale Murphy. Chairman of the Board of Trustees, gives Dr. Jeremiah a plaque stating that the Chapel will now be known as the James $T$. Jeremiah Chapel.
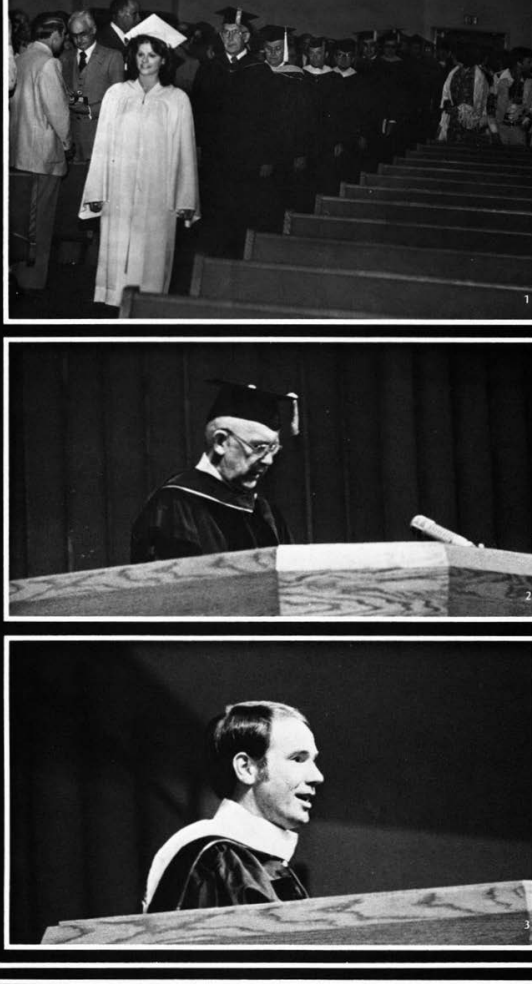


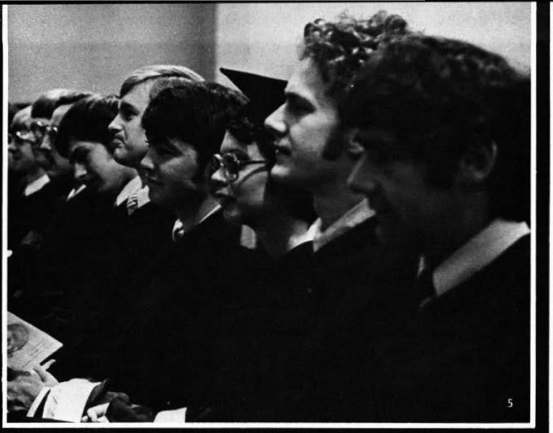

1. Tom Chmura recelves congratulations from Dr. Johnson as he is awarded the

Arthur Franklin Williams Grant as well as the Jimmy O'Quinn Evangelism Grant.

2. The Music Trophy is awarded to

Dianne DeNicola. It is given for

outstanding musical scholarship and for service to Christ through music.

3. Carl Zelonis receives the Martha

Louise Brown Award for his active

participation in Christian Service.

4. The valedictorian of the Class of 1978

is Sandra Sayre Glenney.

5. The expressions on their faces

deomonstrate the sentiments of the

day.

6. Jody Grosh presents Dr. Jeremiah with a plaque signifying the renaming of the President's Trophy to the James T. Jeremiah Trophy.

7. Dr. Jeremiah presents the President's

Trophy to the 1978 recipients, Lydia

West and Kent Amstutz.
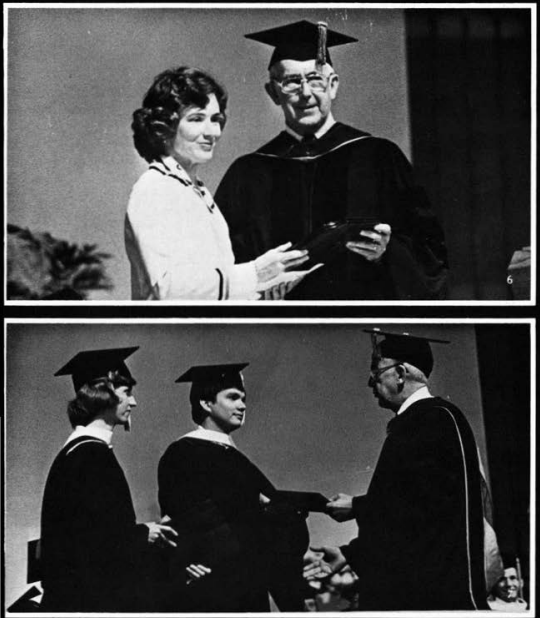

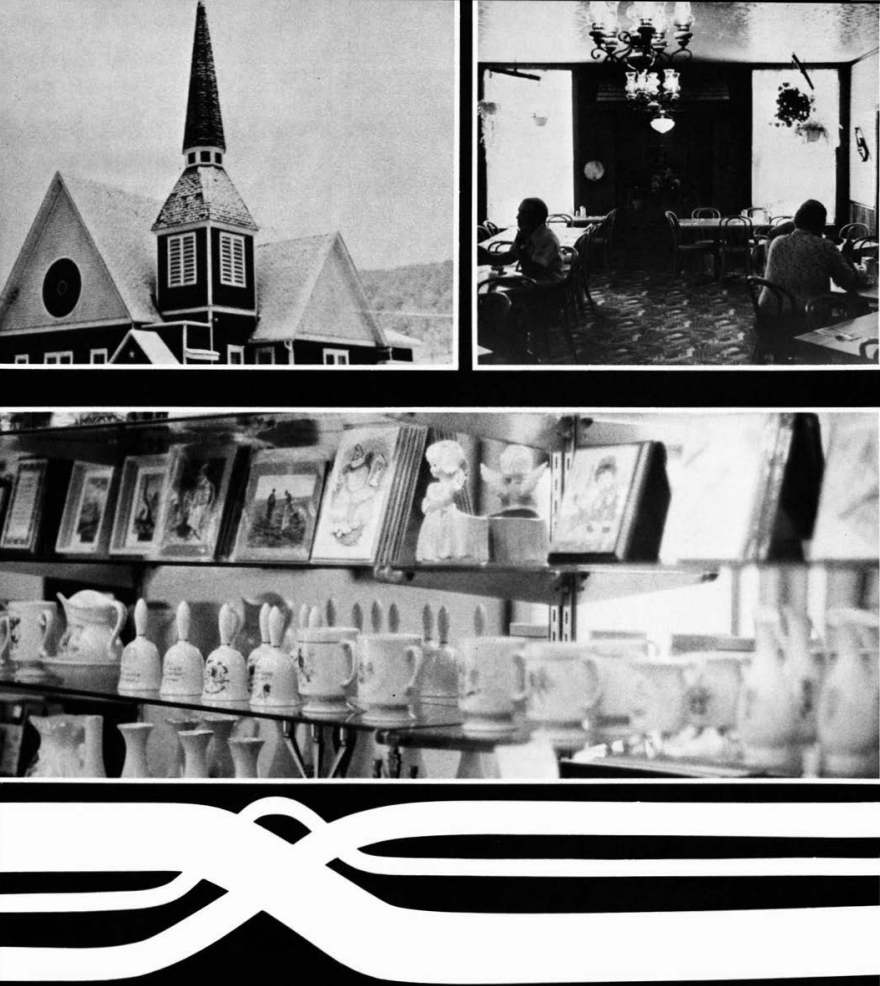

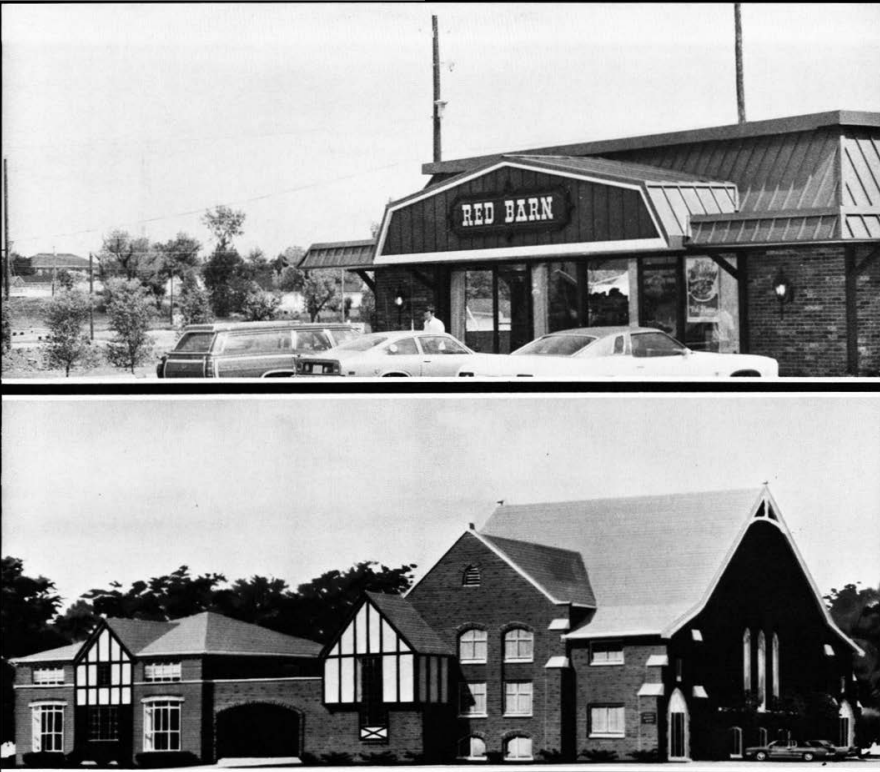

ADS/IINDIEX 


\section{CONGRATULATIONS SENIORS}

Grandview Park Baptist Church

1701 E. 33rd ST. Dos Moines, lowa

Phone 262-8289

"The doors are always open To you"

Dr. Paul Tassell - Pastor

Rev. David W. Board, Sr. -

Assistant To The Pastor

Rev. David McClintic -

Christian Ed. Evangelism

Rev. Elmer Carrithers -

Hospital And Shut-ins

Mr. John Adams

Minister of youth

Mr. Bob Mann - Minister of music

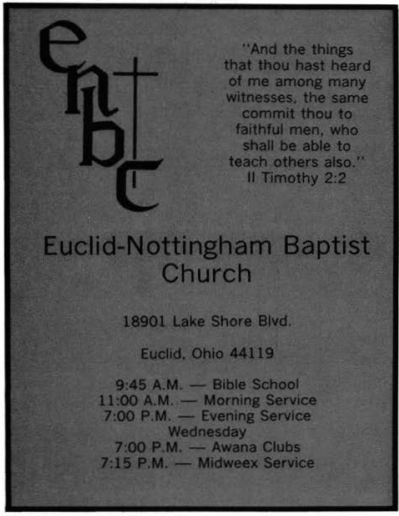

\section{CORNERSTONE BAPTIST $\mathrm{CHURCH}$}

2643 N. Limestone St.

Springfield, Ohio

Pastor Kirk Heldreth invites

many of you to come and

worship with us in our new facilities. 

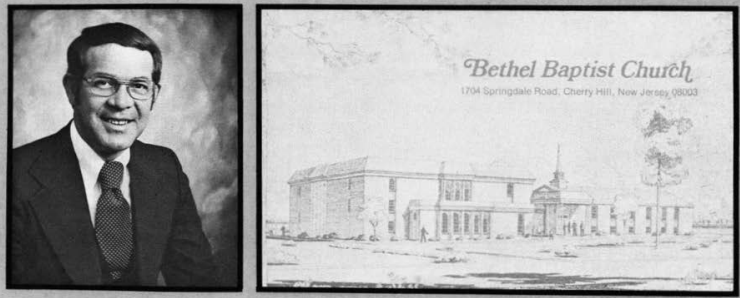

CONGRATULATIONS TO THE CLASS OF 1978

\author{
from The
}

\title{
Bethel Baptist Church
}

1704 Springdale Road. Cherry Hill, N.J. 08003

Rev. Virgil W. Stoneking, Pastor

Wayne Baker, Assistant To The Pastor

Congratulations to the

Class of '78

First Baptist Church

Bremen, Indiana

Rev, James K. Holmes, Pastor

"The Entrance of Thy words

Giveth Light ..." Psalm 119:130

\section{Tabernacle Baptist Church}

1019 N. Cayuga at Lincoin

Ithaca, New York 14850

Rev. Lloyd B. Hull, Ph.D.

"FORWARD WITH CHRIST"

Graduates

David \& Rebecca Nelson

Frederick Rolfe
Huntsburg Baptist Church

Mayfield Rd.

\section{Perry Dr. S.W.}

Canton, Ohio

Rev. Gordon H. Roloff, Pastor

Congratulations

William E. Roloff
Huntsburg. Ohio 44046

Ph. 636-5203

Ben H. Garlich, Pastor

II Tim. 2:15 "Study to

show thyself Approved unto God 


\section{CENTER STREET BAPTIST $\mathrm{CHURCH}$}

1202 S. Center St.

Marshalltown, lowa

Greg Boyle, Pastor

"Jesus said to him, "I am the way, and the truth, and the Life; no one comes to the Father. but through me." John 14:6

\section{Grace Baptist Church}

121 N. Madison Rd.

London, Ohio 43140

Rev. David W. Morris, Pastor

"REACH FORTH, REACH UP REACH OUT"

\section{PK YELLOW SPRINGS INC.}

108 CLIFF ST

YELLOW SPRINGS, OHIO 45387

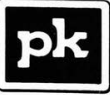

Known for Lumber And building supplies for over a century!

Over 47 years of Service

Foundation materials, lumber, Plywood, Doors \& Windows,

Roofing, Hardware, Paint, Kitchens, Flooring, Storm windows, Awnings, Fence, Tools, Accessories

Del. Service Available

Ph. 767-7426

Open Daily 7:30-5 Sat. 7:30-12
First Baptist Church

125 Grand Ave

Wellington, Ohio

Gerald G. Wagner, Pastor

Students

Fred Greetham Laura Olsen

\section{fimmanuel 角aptist Thurth}

\section{SOUTH DETROIT STREET \\ XENIA, OHIO 45385}

R. William Wheeler, Pastor

A Home Centered

ministry with

A Home Centered

Schoof : 


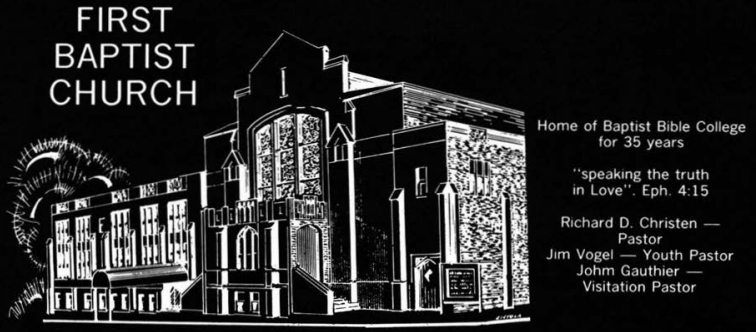

Main At Baldwin Sts. - Johnson City, N.Y. 13790

"Our Warmest Congratulations To

The Class of ' 78 And Our Best

Wishes for Continued Success in Christ"

Students from Church

Kathy Krewson, Nancy Tenney, Dick Krewson, Dan Sorber. Beth Beikert
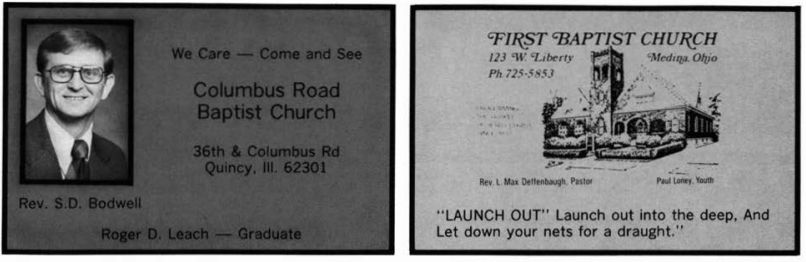

\section{Immanuel Baptist Church}

3417 Palmetto Ave

Columbus, Ohio 43204

Ph. 274-2687

Best wishes To Class of '78

\section{First Baptist Church}

3rd Ave AT Locust ST.

Gallipolis, Ohio 45631

Home of Ohio valley

Christian School

$\mathrm{Ph}$. (614) 466-0374

Joseph L. Godwin, Pastor Alvis G. Pollard, Youth Director 


\section{MERCERVILLE BAPTIST CHURCH}

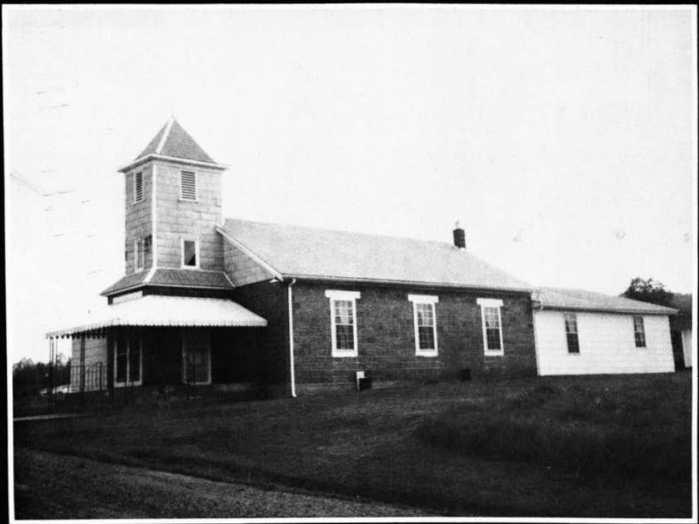

MERCERVILLE, OHIO

Rev. Jack Templeton, Pastor

"Trust in the Lord with all thine heart; and lean not unto thine own understanding. In all they ways acknowledge $\mathrm{Him}$. And $\mathrm{He}$ should direct thy paths". Prov. 3:5,6 Jeff Donnison - Freshman student 


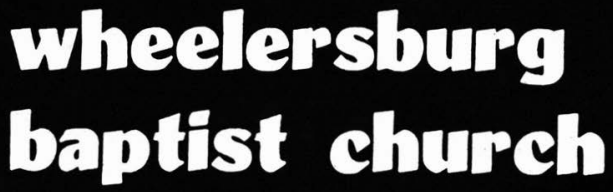

8140 Gallia

Wheelersburg, Ohio 45694

"Let your light so Shine

Before men, that they may

see your good works, and

glorify your Father, who

is in Heaven." Mathew 5:16

Dick Sumner Pastor

Donnis Burns Youth

Gary Storm. Director of

Scioto Hills Baptist Camp

1878100 Years Preaching "You must be Born Again" 1978

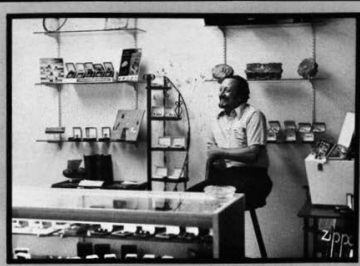

Diamonds • Watches • Jewelry WILLIAM'S

\section{JEWELERS}

Suite $2 \mathrm{~W}-2$ nd Floor

Peoples Savings \& Loan Bldg.

100 West Main St. Xenia, Ohio

BILL BLOCK Phone 372-1444

"Bless you one and all"
The Bible Baptist

Church of Washington D.C.

James D. Parker. Pastor

1705 East-West Hwy Apt. 702

Silver Spring, Md. 20910

(301) $585-1405$

verse - (Acts 1:8)
Sun Coast Baptist Church

John M. Polson, Pastor

19 E. St. Rd 54

New PORT Richey, FI. 33552

"Commit thy works unto

the Lord, and they

thoughts shall be

Established." Proverbs 16:3 


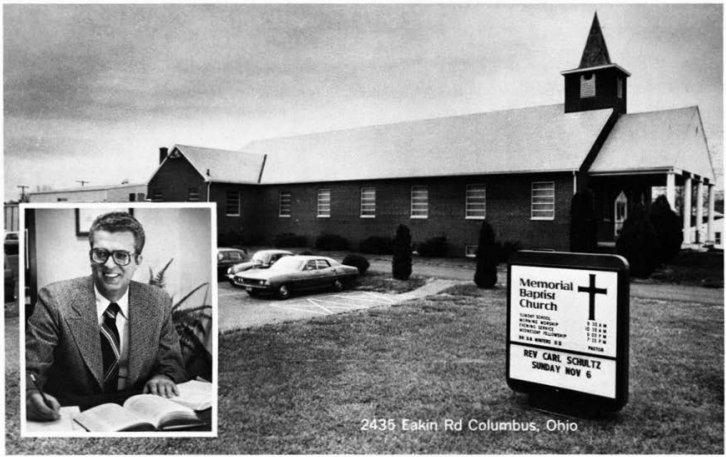

\section{JOHNNY'S AUTO PARTS}

50 N. Main

Cedarville, Ohio

766-2381

Machine Shop

\section{Young's Jersey Dairy}

\section{"the dairy with cows"}

Jersey Ice Cream

many Flavors

Ph. 325-0629

Open 24 hrs, everyday

1 mile north of Yellow Springs

Cones

Sundaes

Shakes

Donuts

Cookies

Cakes

Hamburgers

Sausage

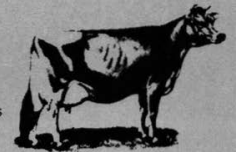


Mr. \& Mrs. Arthur J. Abbott

139 Green Acres Dr.

Liverpool. New York

James R. Abercrombie

27212 Huron R. Drive

Flat Rock, Michigan

\section{Mrs. John Aitken}

319 Ottawa Ave.

Hasbrouck Heights, New Jersey

Dr. \& Mrs, John S. Alvey

7356 East 100 South

Marion, Indiana

Dr. \& Mrs. Harold E. Amstutz.

321 Shettield Rd.

Cherry Hal, New Jersey

Mr. \& Mis. James Anderson

1909 Dominion Dr.

Ft. Wayne, indiana

Mr. \& Mrs. R.L. Beacham

1240 Christiana St

Elkhart. Indlana

Mr. \& Mrs. Bud Bearss

R.R. 1

Waveland. Indiana

Clinton K. Beckett

2925 E. Ave

Hurricane, West Virginia
Mr. \& Mrs. Kenneth J. Bos

2940 ivanrest

Grandville, Michigan

Mr. \& Mrs. Karl B. Bradshaw

54 Topstone Dr.

Danbury, Connecticut

Wiliam \& fane Bradway. Ir

27 Market St.

Port Norris, New Jersey

Mr. \& Mrs. Wayne Bridges

6036 Madison Pike

Independence, Kentucky

Mr. \& Mrs. Robert Brooks

7263 Ward Road

North Tonawanda, New York

Mr. Y Mrs. Robert Brower

267 Voorlus Ave

River Edge, New Jersey

Mr. \& Mrs. Richard C. Brown

7481 Downing St.

Dayton, uhio

Mr. \& Mrs. Richard L. Browne

780 Columibia Rd. N.W.

Washington, D.C.

Dr. Ronald R. Bubel

Box 431

Wessington Sprines. South Dakota

\section{GRACE BAPTIST $\mathrm{CHURCH}$}

Paul Jackson, Pastor

Wishing An Abundant Life to the 1978 Grads

North Main ST. Cedarville, Ohio

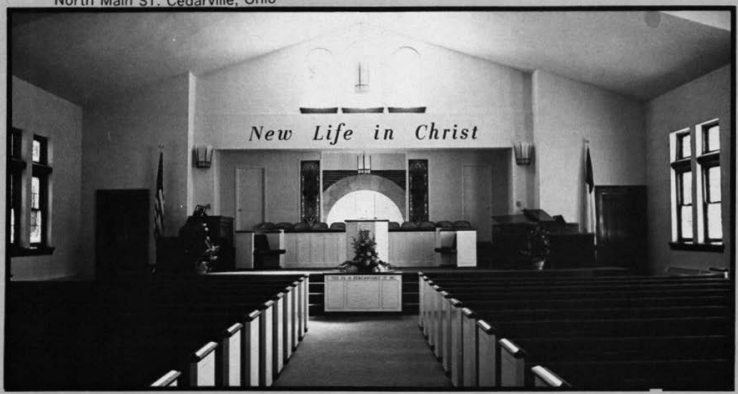



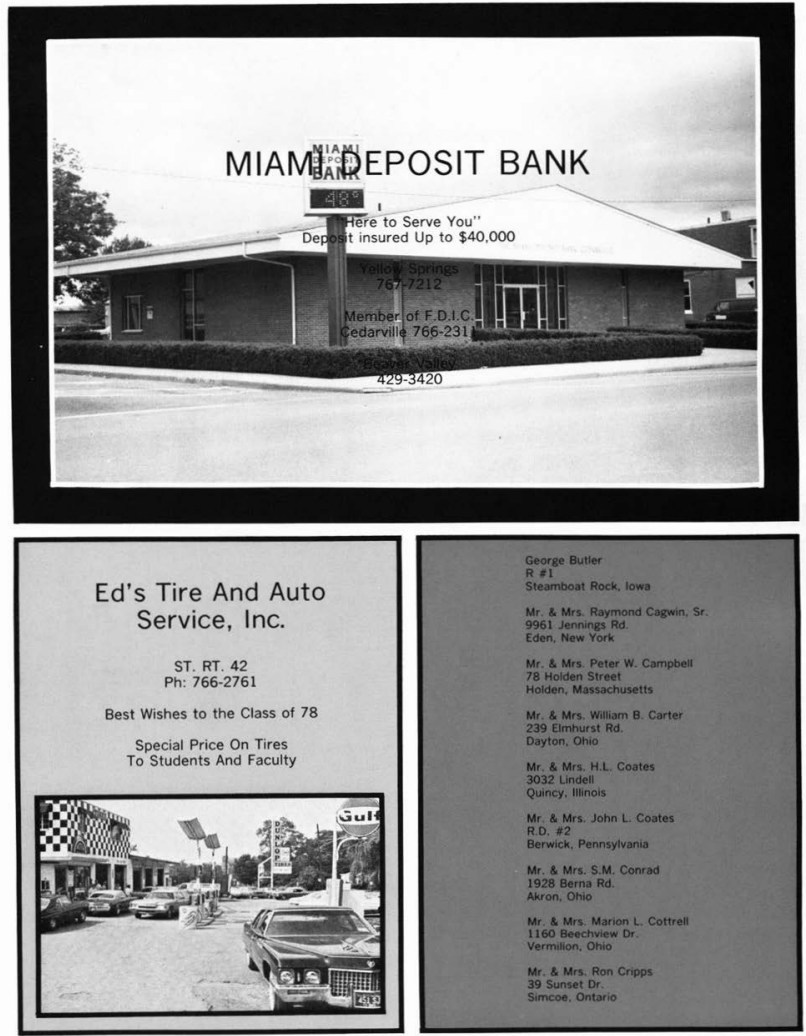
Mr. \& Mrs. Georpe Crompton

16 Burlington Avenue

Voorheesy. New Jersey

Edna $C$. Cunningham

410 West Avenue

Northuale, New Jersey

Mr. \&. Mrs. Louis Cvetich

1017 Roosevelt St.

Conway. Pennsylvania

Mr. \& Mrs. Haymond G. Dailey

439 W. Willow

Lombaro, Illinois

Leonard Deal

64 N. Hudson

Coldwater, Michigan

Mr. \& Mrs. Fred Delp

10588 W. Windon Ct.

Cincinnati. Ohic

Mr. \& Mrs. Dan F. DeMarco

R.D. \pm 2

Ripley. New York

Mr. \& Mrs. Thoedore DeShields

1429 Kaighn Avenue

Camden. New Jersey
Mr. \& Mrs. Wiliam Drumrner

1035 Windy Hill Hd

Fairview Vilage, Pennsylvania

Mr. \& Mrs. Henry H. Duncan

7314 Yellow River Rd:

$\mathrm{Ft}$. Wayne. Indiand

Mr. \& Mrs. Leroy Dyer

33 Deland Ave.

Columbus, Ohio

Mr. \& Mrs. John Ebel

R.D. $\# 1$ 800 88

Grovo City. Pennsyivania

Mr. \& Mrs. Richard Emery

30209 Forest Grove Road

Willowick, Ohio

Mr. \& Mrs. Harry R. Erny

1411 Beverly Rd

Burlington. New Jersey

Mr. \& Mrs. Robert J Farmwald

15150 White Rd

Middlefield, Ohio

Paul H. Festag

712 Hopkins S

Eimira. New York

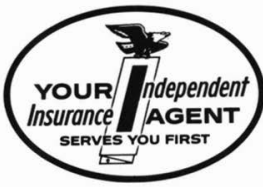

Life

Auto

Fire

Boat

Bonds

Home Owners

Health

Pension Programs

\section{GERARD}

Since 1896

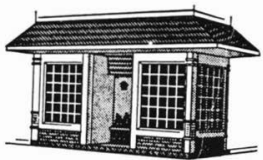

"Insure with Confidence"

\section{A FULL SERVICE AGENCY}

$1 \mathrm{~W}$. Washington

Jamestown, Ohio

Earl Gerard - Res. 372-2600

Dick Baker - Res. 426-2920

Business - Farm - Industrial -
For Friendly

Service

675-9321

$372-2600$ 


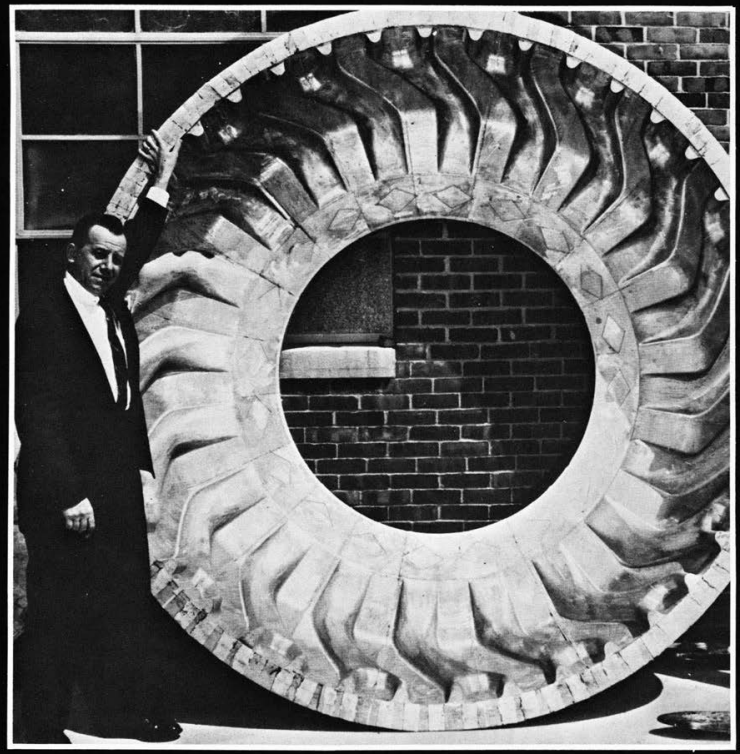

\section{MORRIS BEAN \& CO.}

Best Wishes To

Class of '78 
Mr. \& Mrss Donald R. Flood 12605 indian Hollow Road Gratton. Ohic

Mr. \& Mrs. Thomas J. Footman

4213 Calborne Rd

Battimore, Maryland

Mr. \& Mrs. Joel F. Fowler

3232 Piatt

Mattoon, Iilinois

Mr. \& Mrs. Kenneth Franks

2681 Cyclorama Dr

Cincinnati. Ohio

Rev. \& Mrs Graham Freeman

404 S. Main St

Muncy, Pennsylvanis

Mr, \& Mrs. Donald F. Frey

440 Mock Rd

Pottstown: Pennsylvania

Mr. \& Mrs. Lauren E. Gall

3445 Palmer Highway

Britton. Michigan

Mr. \& Mrs. Carl Gawthrod

Rt 2 Box 273

Fairmant, West Virginis

Mr. \& Mrs. Richard L Yater

R.R. 3
Crawfordsville, Indiana

Mildred 8. Zachary

226 Oak Park Di

Breuard, North Carolina

Ron 8 Eridgot Bonzo

9 Grandiew Ave

Jackson, Ohio

Mr. \&. Mrs. Harry S. Crist

64 Union St

Pernsville, New Jersey

Richimond Donaldson

Box 322

Geigertown, Penna

Mr. \&.Mrs. Edward Dresbach

17 Iones Dr

Schenectady. New Yorh

Mr. \& Mrs. Dewitt Fields

Box 25

Kodials, Alaski

Mrs. Jerry Goheen

R.R. 1

Carrington, North Dakoto

R.V. Traphagen

Mr. \& Mrs. W.R. Van der Hoeven

10 Roliing Hill Rd

Ridgefield. Connecticut

Mr. \& Mrs. Clare M. Vernon

8221 Sheridan $R A$

New Lothrop: Michigan

Mr. \& Mrs. Stephen Vesitko

4182 New Road

Austintown, Onio

Mr. \& Mrs. J.H. Wainwright

$465 \mathrm{E}$. Delaware Ave

Roebling. New Jersey

Mr. \& Mrs. Hiram J. Wafter

306 Evergreen Avenue

Westmont. New Jersey

Rev. \& Mrs. Maynaed Waterman

Thurman \& Knowlhurst Baptist Churches

Warrensburg New York

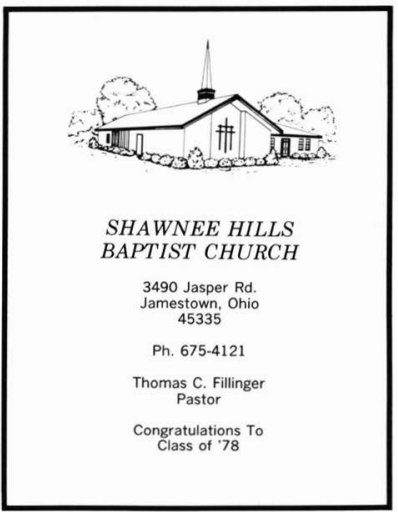

Advertising/261 
Charles H. West

285 W. Robbie Lane, $472 \mathrm{~N}$.

Valparaiso, Indiana

Mr. \& Mrs, Willam Whitacre

2476 Bridge Road

No. Fort Myers, Florido

Mrs. Pouline F. Wiggin

1223 Ventura Lane

Ft. Wayne, Indiana

Mri \& Mrs. Jack Wilcox

3391 E. Soratoga Rd.

Langley, Washington

Mr, \& Mrs, C. Russeil Wildermuth

3320 Upland Avenue

Boothwyn, Pennsyfvania

Mr. \& Mrs. Gordon Wind

612 W. Devlin St

Spring Valley, Ilinois

Mr. \& Mrs. John Wisnaski

6898 N.W. 12 th Court

Plantation, Florida

Mr. \& Mrs Raphael G. Woift. Ir 4517 Morning Wind Place

Fort Wayne, Indiana

Mr. 8 Mrs. Francis A. Wozinak

3102 Johnson $\mathrm{Cr}$. Rd.

Middleport. New York

Mr. \& Mrs: Clarence F. Wright

Box 146 Route 3

Laurel, Delaware

Mr. \& Mrs James Tawney

108 Koentz Ave

Clendenin, West Virginia

Mr. \& Mrs, Edward A. Taylor

9844 Bascom Rd

Chardon, Ohio

Dr. Francis L. Tayior

3795 Woodbridge Road

Columbus. Ohio

Mr. \& Mis. Raymond D. Tayior

2623 Wedgewood Rd.

Des Moines. lowa

Mr. \& Mrs. Henry J. Teckmeyer 6759 Lafayette Avenue

Omaha, Nebraska

Mr. \& Mrs. Ronald Tenney

6 Lincoin Ave.

Binghamton. New York

Mr. \& Mrs, Louis Terlouw

Rt. 1

Prairie City, lowa

Mr. \& Mrs: George P. Terwilleger 44 West Saddleriver Rd

Waldwick, New Jersey

Mr. \& Mrs, Aulrey Mohier

8389 Spieth Road

Litchfieid, Ohio

Dr. $\&$ Mrs. Allen L. Monroe Box 601
Cedarville. Ohio

Mr. \& Mrs: Amos W, Moore 2489 Avondale Ave.

Rosiyn, Pennsylvania

Mr. \& Mrs, Dale Moore

R.R. $¥ 2$

Peru. Indiana

Mr. \& Mrs: Judsan O. Moore 76 W. Main Street

Port Norris, New Jersey

Mr. \& Mrs. Rutus L. Morgan

50411 th Avenue

Haddon Heights, New Jersey

Pastor \& Mrs. Harry Mullican Orviston, Pennsylvania

Wm. H. Napier

804 Avenue E

Fort Madison, lowa

Mr. \& Mrs. Richard Oliver

2925 Lovers Lane

Zanesville, Ohio

Mr. \& Mrs. J. Norman Ouellette

Box 27

Canaan, Maine

James \& Mary Parker \& Family 1705 East-West Hwy A702

Silver Spring, Maryland

Mr. \& Mrs, Clayton H. Partridge 67 Miriam Ave.

Blasdell, New York

Dr. \& Mrs. Charles N. Patton

Lafayette. Indiana

Mr. \& Mrs. Duane D. Perry

1556 State Rd

Wyoming. New York

Rev. \& Mrs. Douglas Peters 1375 Farnham Rd

Troy, Ohic

Mr. \& Mrs. Dave Petro

811 Buckingham

Flint. Michigan

Mr. \& Mrs. Edward Pilarczyk

11680 Clay St.

Huntsburg Ohio

Gail Poole

1151 W. Nine Mile Apt. $\# 6$

Ferndale, Michigan

Mr. \& Mrs. Ernest B, Rogers

21657 th St.

Byesville. Ohio

Mr, \& Mrs. Irvin A. Rollman 225 Ciliton Ave

Reading. Pennsylvania

Rev, \& Mrs. Ernest Ronk

909 E. Main St

Millville, New Jersey

Mr. \& Mrs. Richard Rose

R.R. 3
Eldora, lowa

Mr. 8 Mrs. Alfred Said

952 Pepperwood Lane

Brunswick, Ohis

Mr. \& Mrs. Otha Sanderlin 2349 Summit St

Portsmouth. Ohio

Mr. \& Mrs. Vincent Sayre

R.D. \#2

Carthage, New York

Fred \& Gladys Schieber

$800 \mathrm{~N}$ York Road

Warminster. Pennsylvania

Mr. \& Mrs. R. Schierwagen

33 Chestnut St.

Pearl River. New York

Mr. \& Mrs. Watt W. Seawell

729 Navajo Trail

Macedonia. Ohic

Mr. \& Mrs. George Webt

541 Prospect Ave

Hackensack. New Jersey

Dick \& Nancy Welier

115 Brandies Rd. E.

Caltahan, Forida

Mr, \& Mrs. Gerald W. Thomas Rt. 1

Parma, Idaho

Jack Tindail

5866 Hasner Rd

Oxford. Michigan

Mr. \& Mrs. Leneal Potter

$R D=2$

Allegany, New York

Mr. \& Mrs. George A. Price

1550 A US 19 Narth

Port Richey, Florida

Mr. \& Mrs, James Risser

R.R $=3$

Forest. Ohio

Mr \& Mrs. Tosef Rohde

2820 Alda Parkway

Brunswick. Ohio

Mr. \& Mrs. Charles E: Segerstrom 1207 Wiltiston Avenue

Waterloo. lowa

Rev. \& Mrs. Dovid H. Selden P.O. Box 231

Huntsburg, Ohio

Edgar W: Seymour

2 kirby Rd.

Freeville. New York

Myri L. Short

850 Highland $\mathrm{Dr}$

Wauseon, Ohio

Mr. \& Mrs, Roy L. Shumaker 1620. Exete Rid

Westminster, Maryland 
Mr. \& Mrs. Roger Shuneson

1184 Winding Way

Charlotte, Michigan

Mr. \& Mrs. William W. Sirket

7911 Meadowtirook Di

Indianapolis, Indiana

\section{Elaine Carl Smith}

$\mathrm{RD}=1 \mathrm{BO} \times 227$

Chester, West Virginia

Mr. \& Mrs. Charles Snook

5160 Uirts Rd.

Mechanicsburg, Oho

Mr. \& Mrs. Frederick E. Somers 9224 Darke-Monte. Co. Line Road Brookville. Ohio

Mr. \& Mrs. Doyle Putman

R.R. 1

Argos, Indiana

Mr \& Mrs A Rapinchuk Jr.

102 S. Adams

Westmont. litinois

Rev. \& Mrs, Marlin Rayburn

157. Creamer Driver

Cedarville, Ohio

Mr. \& Mrs. Irwin M. Rehn

202 Crown Roart

Boonton, New Jersey

Mr. \& Mrs. Elmer Reu

225 S. Michigan

Villa Park, Iltinois

Rev. \& Mrs. Merle Richardson

P. D. Box 235

Huntsbure, Ohio

Mr. \& Mrs. James P. Riddle

14321 L.oulsa St

Woodbridge, Virginia

Mrs. Esther M. Riggs

6001 Falcon Lane

Indianapolis, Indiana

Mr. \& Mrs. Robert C. Sparks

116 Jordan Road

Brick Town, New Jersey

Mr \& Mrs. Charles R. Spicer

5501 Ledge Rd

Madison, Ohic

Mr. \& Mrs. Danny L. Sprodling

807 Boylston So

Middletown, Ohio

Richard \& Jean Steinhofer

310 Lacey Drive

New Milford, New Jersey

Mr. \& Mrs Jack Stephenson

1314 53rd St

Moline. lilinois

Mr. \& Mrs. Al Stevens

303 Somers Ave

Moorestown. New Jersey

Bill \& Marilyn Stevensan

236 W. Pine St
Audubon, New Jersey

Mr. \& Mrs. Keith Streitmatter

R. 5 Box 33

Renssilaer, Indiana

Leighton J. Stump

12404 Patterson Rd

Wakarusa. Indiana

Mr. \& Mrs. Peter P. Surso

$1351 \mathrm{~N}$. Circleview Dr.

Seven Hills; Ohio

Mr. \& Mrs. Donald Harper

340 Kathleen Dr.

Des Plaines, Illinois

Pastor \& Mrs. Georre Hattenfield 45 Oakland Park Ave

Columbus, Ohio

Mr. \& Mrs Cecil D. Hayes

Rt. $\# 6$ Box 151

8rownsburg. Indiana

Mr. \& Mrs Lawrence Haynes

P. O Bax 333

Hinckley, Ohic

Wayne Hea

RR 2 Box 98

Bunker Hill, Ilinais

Mr. \& Mrs. Bill C. Heatly

2390 Tamara Rt. 4

Kalkaska, Michigan

Mr. \& Mrs. John W. Heffernan

9 Beechland Court

Montrose, New York

Carl \& June Hermansky

433 Washington Place

Hasbrouck Heights, New Jersey

Mr. \& Mrs. Dean Jones

E. 11622 24th

Spokane, Woshington

Mr. \& Mrs. Donald Jones

3146 Warren Rd.

Cline, Ohio

Mr. \& Mrs, J. Stephen Jones

Rt. 1 Box 14

Argos, Indiana

Mr. \& Mrs. Hugh KahI

8034 Gordon Place

Highland, Indiana

Mr. \& Mrs. Dillon Karsian

269 Poplar Avenue

Hackensack. New Jersey

Rev, \& Mrs. George H. Keller Appalachian Bible Institute Bradiey, West Virginia

Mr. \& Mrs. Peter Kerrigan

167 Kent Street

Hackensack, New Jersey

Mr. \& Mrs. Stanley Kirby

Prospect, Ohio

Colleen K. Kirk
1039 Longwood Ave.

Cumberland, Maryland

Rev. \& Mrs: Frank M. Kisner. 468 Shady Lane.

Wisconsin Rapids. Wisconsin

Fev, \& Mrs. John Hippard

$520 \mathrm{~N}$. Vine St.

Shelbyville, Illinois

Mr. \& Mrs, Wiliam J. Howe

420 Nevada St.

East Alton, Ittinois

Francis L. Hoy

Box 22 RO. 4

Halifax, Pennsylvania

Mr. \& Mrs. Paul Hunn

200 Marilee Drive

New Lebanon. Onio

Mr \& Mrs. William T. Hutchins

RR. 2 Box 447

Corning, New York

Mr. \& Mrs. Joseph A. Jansen

210 Garmatter Street

Bluftton, Ohio

Mr. \& Mrs. Everett S. Jarvis

Route \#1 Box 39

Guysville. Ohic

Harold \& Janet Jarvis

763 Bernice Ave

Rohnert Park, California 


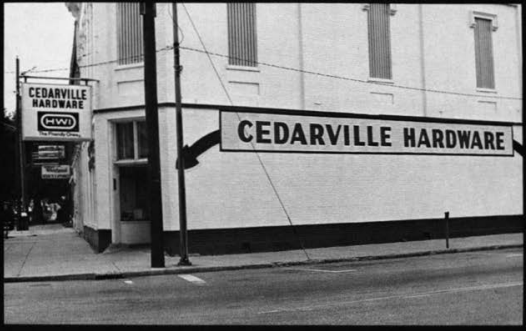

\section{Cedarville Hardware}

For Your

Best Deal

in

General

Electric

Appliances,

Housewares

and Gifts

FREE GIFT WRAPPING

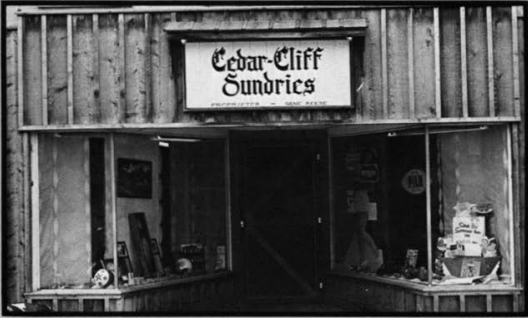

Cedarcliff Sundries

Gift items. cards, magazines Drug items.

open 9 am -8 pm

Mon.-Sat.

$77 \mathrm{~N}$. Main St.

Cedarville, Ohio

Mr, \& Mrs. Elmer G. Martir

Rt. $\$ 2$ Box $\$ 70$

Grethel, Kentucky

Mr. \& Mrs. Robert L. Medloch

3420 No. 37 th

Tacoma, Washington

Mr. A Mrs. Daniel W. Matter. Jr.

Rev. \& Mrs. Messenzer

5010 Driftwood Dr.

5531 Lunstord Drive

Fort Wayne. Indiana

Indianabolis. Indiana

Mr. \& Mrs, Robert McBride

Mr. B. Mrs. Bill J. Mick

10233 Dodge tane

Box 329

Louisville, Kentucky

Clendenin, West Virginit

Mr. \& Mrs. Paul McMiltar

Mr \& Mrs Russeil A. Miller, Ir

705 College Way

7020 Redmiles Road:

Carmel, Indiana

tauret. Maryland 


\section{Cedarville Dairy Freeze}

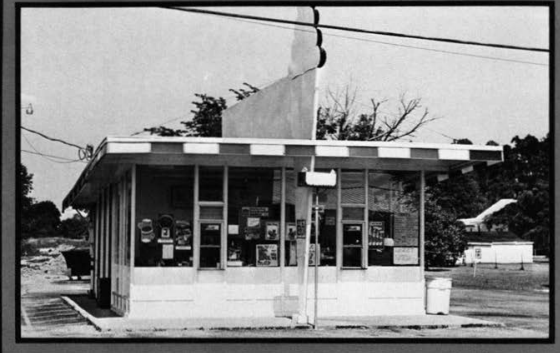

320 N. Main

Cedarville, Ohio

Prop. Jean Leach

Mgr. Carolyn Morris

Employees

Wayne Cahilly

Jan Callan

Lori Leach

Mary Meyer

Wally Rader

Debbie Schieber

Nancy Snook

Jenny Wright

And unto man he said, "Behold, the fear of the Lord, that is wisdom; and to depart from evil is understanding."

$$
\text { Job 28:28 }
$$

\section{S. Center Blvd.} Springfield, Ohio

Pastor: Dr. J. Murray Murdoch

Ph. (513) 325-0619

Southgate Baptist Church

Mr. \& Mrs. Jerry Knight

Steamboat Rock. lowa

Mr. \& Mrs. Karl J. Koch

9817 Ridge Rd.

Middleport, New York

Mr. \& Mrs, Raymond M. Kulp

R.D. 2 Box 87

Port Allegany. Pennsylvania

Mr. \& Mrs. Robert H. Lane

60855 County Rd. 13

Goshen, Indiana
Mr. \& Mrs James A Larson

12551 Blue Spruce Dr., R.D. 3

Edinboro, Pennsylvania

G.A. Lechner

$772 \mathrm{~W}$. Woodland

Paltine. Illinois

Mr. \& Mrs. Wm. E. Leightenheimer

1129 Eighth Street

Portsmouth, Ohio

Clayton H. Lewis

$1429 \mathrm{~N}$. Woodlawn

Griffith. Indiana 


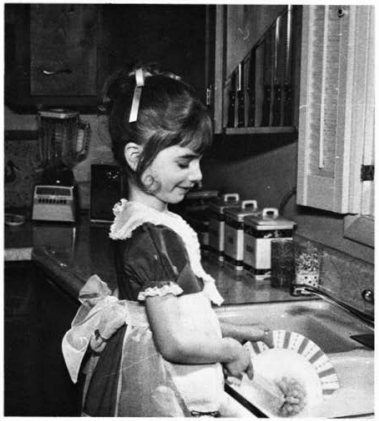

TREAT YOURSELF

TO REAL

SOFT WATER

Water softener sales, service, rentals, salt

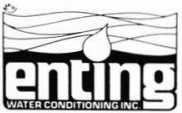

3249 Dryden Rd.

Dayton, Ohio 45439

(513) $294-5100$

DEALER INQUIRYS INVITED

Little Girls Love Soft Water ...

So Do Mommies and Daddies!

Mr. \& Mrs. Foster Grace

22357 Champaien

Tayior, Michigan

Pastor \& Mrs: Harold Green

Cedarville College

Cedarvilie, Ohio

Mr. \& Mrs. Fred Greetham

431 Courtland St.

Wellington, Ohio

Mr \& Mrs. Clarence B. Grovat

$\mathrm{RD}$ \#3

Vincentown, New Jersey

Mr. \& Mrs. Earl Hage

RR 3

Covington, Indiane

Duane \& Elaine Harnsen

3761 Carson City Rd

Sheridan, Michigan

Mr. \& Mrs. Wallace E Harison

1242 N. 11 th St.

Fort Dodge. Iowa

Mr. James L Hammond

114 South Lake St.

Amherst. Ohio
"Let your light so shine before men, that they may see your good works, and glorify your Father which is in heaven."

- Matthew 5:16

\section{YELLOW SPRINGS}

\section{NEWS}

\section{May God's grace lift us all into the glory of His Kingdom}

Best Wishes

from the Staff of the

Yellow Springs News 


\section{A friendly place to shop}

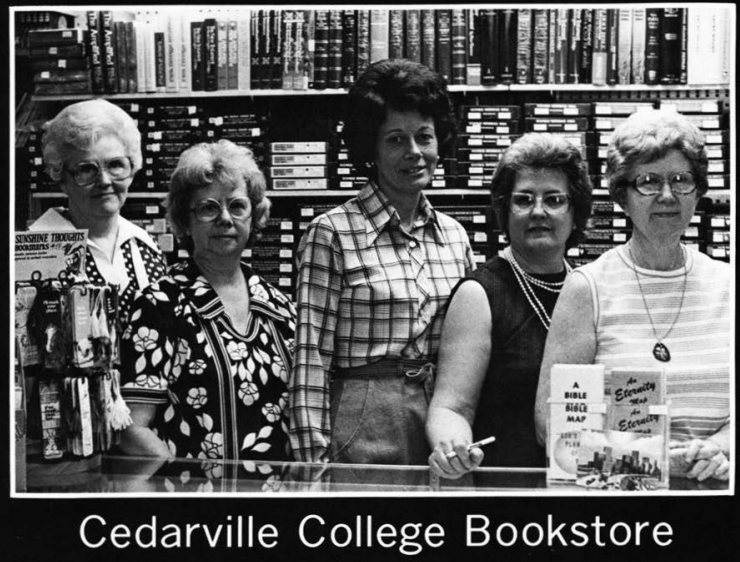

Congratulations to the Class of 1978

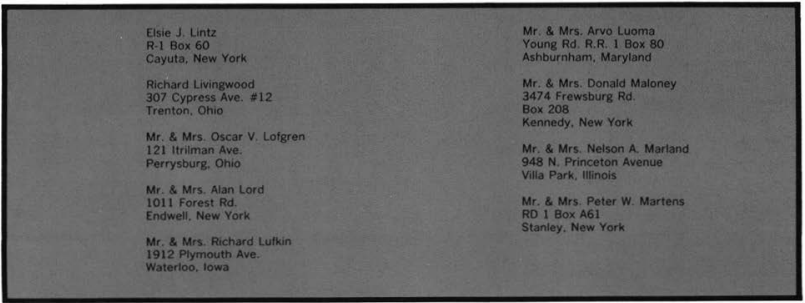




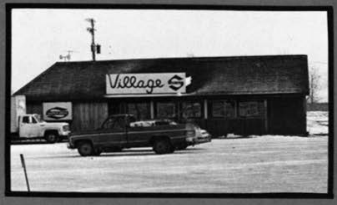

Village Super Valu

360 N. Main St.

"Your Kind of Food Store"

Home of Low, Low Prices

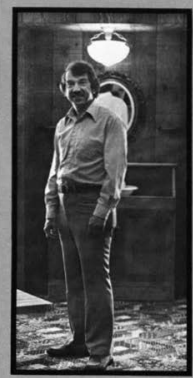

First Baptist Church $1001 \mathrm{~N}$. Lincoln St. Creston, lowa

$782-5417$

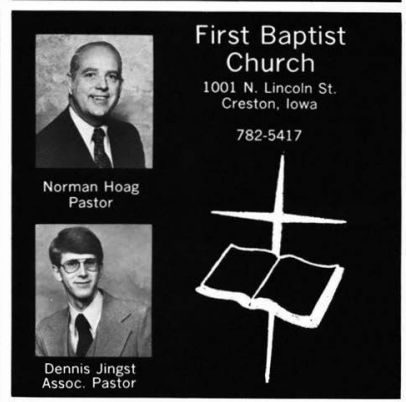
salvation.

Behold, God is my salvation: I will trust, and not be afraid: for the Lord JEHOVAH is my strength and my song: He also is become my

Isaiah 12:2

North Baptist Church

2052 St. Paul St.

Rochester, N.Y.

Pastor: Ralph E. Gruenberg DCE: Walter G. Lapp

Principal: Eari Van Den Berg

Isaiah 12.2

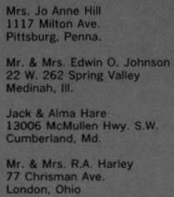

Mr. \& Mrs. W. S. Lewis

2716 Croshaw Rd

Wrightstown. N.J.

Mr. \& Mrs. Jack W. Limbaugh

Box 695

Algona, lowa

Mr. \& Mrs. George Mitchel

315 Broadway

Brooklawn, N.J.

Mr. \& Mrs, Louis Moberly. Jr

105 Lesdale

Troy. Mich. 
Abbott, Gary, 176

Abbott, Ronaid, 176

Abels, Nancy, 202

Abercrombie. Jim

Abernathy, Wiliam, 103, 104, 131, 202, 209

Acker, Jetf, 139, 190

Adams. Barbara, 12, 127, 190, 191

Adamson, Donald, 24, 139, 176

Addision, Nanetle, 115, 214

Adkins, Cathy, 190

Athen, Thomss, 52, 54, 190

Alcorn, Marvin

Allen, John, 202

Allen, Michaed, 64, 135, 190

Alspaugh, Cheryl. 214

A)timus, Tim, 142,21

Alvey. John, 214

Amstutz Kent 17, 100, 127, 214, 247

Anderson. Crystat 59, 70, 135, 202

Anderson, James, 176

Anderson, Janice. 120, 138,214

Anderson, Joyce, 214

Anderson, Keith, 124, 135, 137, 176.

Anderson, Kenneth

Anderson, Kim, 123, 214

Anderson, Kris, 202

Anderson, Mark D, 136, 176

Anderson, Mark L, 77, 176

Anderson, Scot1, 133, 135, 214

Anderson, Tonya, 104, 125, 136, 176

Andrus, Kenneth, 190

Angel, Karin 44, 102, 143, 202

Apperson, Charles, 176

Apple, Binda, 33. 215

Arthur, Jone, 140, 215

Arthur, Sarah, 108, 122, 190

Arvay, Paula, 100, 202

Ashley, Roger, 202

Alkinson. Bryce, 190

Auwarter, Clay, 54, 215

Avery, N Lee. 124, $129,159,215,242$

Babcock. Edward, 202

Baden, Gary. 176

Bahorik, Scott, 133, 190

Baley. Thomas, 176

Baker, Pamela 202

Baldwin, Bat 79. 81. 190

Banks, Elizabeth. 215

Banner, Cindy, 202

Balcwin. Bal. 79. 81,190

Banks. Elizabeth, 215

Banner. Cindy, 202

Barker, Anne, 125, 176

Barrett, James, 202

Basye, Daniel, 16, 17, 215

Beacham, Deborah. 176

Beach Jeftrey, 202

Bearss, Laura. 176

Beatty, Jodie, 202

Beck, Clayton, 176

Beckett, Beth, 176

Becket. Bevid, 125

Begue, Surette, 176

Beight, Scott, 118, 190

Beikert. Barbara

Beikert. Beth, 127, 152, 176

Belleman, Benny, 52, 54, 135, 202

Benetiel, Tom, 52, 54, 111, 135, 215

Benson, Nerman, 215

Bentley, Mike, 102, 123, 124, 202

Bentley, Rito, 215

Bergandine, Dave, 94, 176

Betts, Daniel, 190

Betz, W. Dale, 176

Bibeau, Donna

Bigelow, fonald. 30, 31, 104, 129, 132, 202

Bilings, Debra, 88, 90, 176

Birch, Carleton, 54, 142, 143, 176

Birk. Timothy, 97, 202

Birk, Timothy. 97,202
Bish, Timothy. 176

Blackburn. Eeth

Blackburn. Debra, 103, 121, 124, 137, 143.

138, 202

Blackburn, Rebecca, 120,176

Biasdell Joanne, 127, 176

Blue, Richard 202

Board, Sue 141,202

Bocian. James, 190

Bonro. Debbie 176

Bonzo. Sandra. 115. 190

Book. Puth Ann: 190

Bos. Timothy, 125. 216

Boston, Mary, 176

Boston, Mary, 176
Bowers, John, 202

Bowman, Melinds, 119,176

Brace. Grey. 190

Bradshaw, Joann, 118, 122, 176

Brady, Lyndon, 176

Arasz, Robert. 139. 190

Brecher, Kimberlee, 119, 126, 141, 176

Bresson, Betsy. 176

Bresson, Danie!

Bresson, Mike, 190

Bridges, Jody, 106, 176

Briegs. John, 190

Brinkman. Nelson, $20 ?$

Broach, Terry, 129,142,202

Brooks, M sue, 110,176

Brower, Kathieen, 105. 190

Brown Judy, 12, 190

Brown. Coessa, 115, 216

Brown, Dale. 202

Brown, David. 176

Brown, Roberta. 202

Brown, Shirley, 176

Brown, Steve, 190

Browne, Kevin, 103, 190

Browne, Scott, 126, 129, 132, 133, 202

Bruening Laurie. 112, 190

Brumbaugh, Michael, 43, 127, 139

Bubel, Janet, 115, 202

Buettell, Paul. 190

Buthuis, Esther

Buthuis, Peter

Bunton. Cathy, 70, 216

Burchett. Linda, 141, 176

Burk, Randy, 176

Burkhart, Ron, 143

Burleson, Cennie, 176

Burleson, Vicki, 114, 216

Burleson. William

Burns, David, 136, 142, 143, 216

Burns, Dennis, 216

Bushang. Gloria, 111, 136, 216

Butcher, Joyce, 190

Butcher, Judi. 190

Butler, Nichaet, 202

Butler, Robert, 176

Butler, $\mathrm{Tm} .176$

Butler, Vicki, 70, 73, 83, 84, 191

Cafferty. Brian, 177

Cagwin, Randy, 16, 17, 81, 135, 202

Canily. Wayne, 177

Callan, Jan. 103.19

Campbell, David, 37, 142,177

Campbel, Randail, 124, 132, 142, 216

Camptell, Steven, 216

Cantley, Shem, 177

Carey. Cheryl, 84

Carey, Steve, 177

Carmean, Pam

Carr, Lorraine

Cart, Scott, 65, 66, 67, 80, 81, 177

Carroll, Bal, 105, 19]

Carrol, David, 217

Carrol, Jim, 81, 177

Carton, Sharon, 107, 117, 140, 217

Carter, lula, 177

Cartwright, Joyce, 208

Case, Barton, 159, 217

Casteflari, Mark. 111, 137, 154, 202

Catellano, August, 202

Castlo, Cindy, 59, 70, 202

Cave. Robert, 118, 136, 202

Cavey, John, 54

Caylor, Sandra. 202

Chaddrick, Karl, 126, 191

Chamberlain, H, Guthrio, 202, 243

Chambers, Rachel, 202

Chambers, Ruth

Champlin. Sondra, 202

Chandier, Scott, 191

Chapman, Karen, 177

Chesser, Dennis, 217

Chipukits, Marie, 90, 217

Chmura. Thomas. 159, 246

Christian. Dale, 104, 191

Christensen, Tammy, 177

Churcha, Steven, 142, 177

Churchward, Kenneth, 191

Clark. Calvin. 56, 87. 177

Clark. Raymond

Clarke, Victeria 244

Clemons. Connie, 60.62, 63, 82, 84. 135

177

Ciough, Deboie, 151, 217, 224, 241

Coates. Cheryl. 101, 177
Coates, Pamela. 106

Cobb, David, 31, 142, 217

Cobb, Judy, 128, 140

Cobb, Rebecca, 217

Colas, Craig, 37, 56, 93, 94, 110, 135, 138.

Colburn, Dave, 217

Colyer, Joe, 134, 177

Commins, Raymond, 177

Compton, Bruce. 218

Conktin, Jeffrey, 38, 76, 77, 127, 135, 141

202

Conley, Farris

Connors, fichard, 122, 126, 128, 191

Conrad, David, 118, 191

Conrad. Diane 218

Cook, Tom 54

Cooley. Douglas. 125. 177

Cornell, Ruth, 59, 202

Cotier, Rebecca, 125, 177

Cottrell, Julia, 119, 177

Cousson, Cheryl, 59, 104, 177

Cowell, Mark. 218, 242

Cowen, Jeftrey. 202

Cox Donald 191

Craip. Kent, 19

Crain, Pat, 54

Crandall, Kevin, 125, 177

Crawtord, James. 208

Crawtord, Judith, 19 I

Cremean, David, 142, 191

Cripps. Pau, 177

Crist, Richard, 87, 191

Crompton, Pichard, 115, 202

Cross, Judie, 60, 61, 135, 218

Cuffman, Michael, 103, 104, 218, 120, 124

Cunningham, Audrey, 203

Curtis, Dawn, 42, 132, 191

Cvetich, Dowid, 37, 118, 177

Dailey, John, 136, 203

Dalby, Pam, 218

Dalitis, Floyo

Danec, Tammera, 38, 110, 122, 141, 191

Danielsen, Cheryl, 203

Dannenberg. John, 113, 142, 143. 218

Danube, Tom, 112, 191

Darling, Jamie, 79, 81,177

Dautel, Detbie, 191

Davis. Clitt, 178

Davis, Dave, 77, 178

Davis, Janet, 33, 105, 178

Davis, Janet Lee, 23, 203

Davis. Jeftrey, 159, 218

Davis. Linda, 178,218

Davis, Linda $M$

Davis. Terti. 104, 191

Davis, Timothy, 191

Dawson. Sandy. 118, 140, 218

Deat, Cheryl, 178

Decker, Bionnie

Decker, Ginny, 44, 120,123, 189, 190

Decker, Jannel, $88,90,102,178$

Decker, Sandra. 33,118, 178

Dedic, Dan, 219

Delange, Ed, 219

Delange, Michele, 219

Delange, Paul, 191

Delp, Kathy, 178

DeMarco, Dan, 54

DeNicola, Diane, 12, 126, 127, 219,246

Dennison Jett, 178

Denny. Cindy, 108, 122, 191

Denny, David, 108, 124, 219

Deshields, Theodore, 66, 110, 138, 174, 178

Dewhurst, Margaret, 178

DeYoung, Janice, 191

DeYoung, LouAnn, 30, 126, 128, 203

Dillinger, Donns

Dillsworth, Gale, 203

Domerese, Sandra. 178

Donahue, Brian

Donahue, Marie

Donaldson, Gordon, 54, 111, 203

Donnelly, Lynne, 119, 203

Dowd, Timothy, 94, 135, 191

Orake, Nancy, 38, 219

Oresbach. Mark, 178

Driscoll, Becky, 108, 120, 121, 136. 203

Driscoll, Jim, 142,17

Drosek, Dovid. 106. 108, 120, 122, 138, 203

Drummer, Diane, 119, 141, 178

Dubke. Donna - 101, 178

Duff, John, 24, 126, 139, 178

Duley, Fred, 127

Duncan, Karen, 203

Dunn, Daniel, 129, 212, 219

Dunn, Tim, 37, 74, 75, 76, 178

Dyer, Karen, 137, 200, 203

Eagleston, Pegzy, 178

Earnhart. Loretta, 203

Eaton, Rosalie, 28, 33, 219

Ebel, Janet, 106, 109, 134, 203

Edwards. Paul, 30, 44, 104, 120, 220 
Glassey, Keith, 204

Glassey. Sherri

Glenney. David, 221

Gienney. Sandra, 221, 246

Globig. Rernee, 124, 139,204

Godby. Wayne, 192, 222

Godby, Willam

Goheen, Lon 122, 141, 179

Gollihugh, Debbie.

Gordon, Terry, 204

Grace, Nadine, 119,179

Gradigh, Linda, 138, 222

Grafton, Linda. 192

Graham, Joy, 112, 138, 204

Grahl, Faith, 126, 192

Grahl, Tim

Grant, Karen, 179

Gray, Karen, 222

Green, Carole. 222

Green, Daniel, 93, 94, 130, 131, 192

Green, Donn, $123,189,192$

Green, Kathy, 83, 84, 85, 222

Green, Sharon, 192

Greening, Mary, 179

Greetham, Fred, 80, 81, 135, 192

Gregary. David, 204

Grezory. Elaine. 59, 135, 179

Grenier. Andy, 142, 192

Greve, Grez, 66, 78, 81, 112, 179

Greve. Marsha, 110, 141. 192

Grier. Kevin 204

Gritfiths, K. 117

Grittiths. Wayne. 192

Griswold, Jil, 62 112, 179

Gromacki, Gary, $97,135,144,192$

Grooms, Dewayne, 204

Gross Gary, 204

Grovatt, Ted, 81, 179

Guenther, Bonnie. 117, 204

Guenther, Cathy, 192

Guenther, John, 179

Guseman, Sandra, 179

Gutwein, Curtis, 56, 179

Haas, Keith, 37, 179

Haga, Karen, 141, 204

Hakes, Kim, 118, 126, 179

Hall, Cynthia, 12, 142, 143, 201, 204

Hall, Nancy, 179

Hallet, Apni, 141, 179

Hamer, Rebecea, 222

Hamiton, Loanns, 179

Hammond, Pamela, 84, 192

Hancock, Stephen, 79, 81, 192

Hansen. Mary Jane, 90, 119, 204

Hanson. Mark. 204

Hanson, Robert, 54, 111, 135, 142, 143, 204

Harding. Kurt, 222

Hardine. Patricia, 83, 90, 179

Hargis, Carla, 137, 138. 140, 222

Markieroad, Dariel, 222

Harkless. Judith. 204

Hare. Diana, 204

Harley, Richard. 192

Harper, Randall, 28, 127, 179

Harreti, Pe28y, 42, 69, 179

Harris, Dalias, 179

Harris, Nary, 58, 59, $132,133,223$

Harricon, Pamela, 223

Hart John 106, 127, 179

Hartman, Denise, 115, 179

Hartsell, Brooks, 223

Harvey. Nancy, 179

Hoselip. Rita, 108

Hottieid, Charles, 192

Hathaway, Kevin, 74, 77, 192

Hattenfield, David, 179

Hattenfield, Debra, 223

Havener, Cynthis

Hayes, Bit, 103, 126, 192

Hayes, Steve, 192

Haynes, Joyce, 133, 179

Heagy, Barry, 223

Heagy. Barry, 223 $125,128,192$

Heffernan, Darid, 87, 192

Heinrich, Cindy, 62, 180

Henderson, Kim, 102, 192

Hennessec, Edward

Hennine Ann, 223

Henslin, Bruce, 56, 57, 87, 102, 223

Hermansky, Kim, 90, 192

Herne, David, 180

Herriman, Janet

Herron, Cheryl, 192

Herwig, Kenneth, 77, 180
Hettinger, Rthonda, 106, 109, 175, 180

Hewit, Yvonne, 107, 138, 180

Heyburn. Karen, 12, 180

Heyworth, Elaine

Hickey. Charles, 103, 180

Hickman, Rick, 64, 87, 180

picks, Daniel, 45, 126, 127, 142, 223

Hicks, Lester. 204

Highman, Mark. 109, 124, 134, 204

Hegnite. Taylet

Hill, Dwain, $79,81,124,135,204$

Hili, Elaine, 223

Hili, Glenn, 208

Hial $\mathrm{Kim}, 70,71.84$

Hill, Marjorie. 180

Hall, William, 180

Hilmes, Angeta

Hinkie, Gary, 118, 204

Minks, Denris, 136,224

Hinks, Judith, 224

Hinks, Pichard, 189. 192

Hippard. Corol, 180

Hobar, Brenda, $60,83,84,85,123,135,192$

Heganson, Tmothy, 102, 123, 180

Hollars, Janet. 192

Holler, Becky, I80

Holler, Bert. 224

Holopeter, Mark, 75

Hoimes. Patricio, 60, 224

Holtz, Cothryn, 180

Horn, John 180

Horne, Marilyn 102, 138, 224, 241

Hosack. Kimberly. 110, 192

Howard, Brenda, 192

Howard, Deborah. 224

Howard, Kevin, $56,87,180$

Howard, Mary, 105, 141. 180

Hone, Gregory, $118,126,138,192$

Hoy, Steve 141. 224

Hoyme. James. 180

Huber, wiliarn

Hudson. Terrell. 224

Hurtman. Carolyn, 126, 192

Hettiman. Donaid. 204

Hutriger, Leste, 224

Hughion, Clyde, 205

Huge, Judy, 205

Hutl, Brian, 55, 57,87, 135

Hull, Bnan, $56,57,87,135$
Humbert, Mary, 138, 142, 144,225

Humble, Heide, 225

Humm, John, 192

Humphrey, Paula, 126, 180

Hunn, Denise, 225

Hunt, James, 36, 77, 127, 142,180

Hunter, Mark.

Hunting. Michael

Hutchins, Julie, 62, 135, 180

Hutchison, Thomas, 87, 102, 123, 135, 205

Hyde, Dernis, 180

Inudo, Yasuaki, 180

isbeli, Sherri, 180

isley, Ronda, 1 80

Jackson, Debbie. 205

Jacksan, Dee, 117, 154, 225

Jackson, John, 205

Jackson, Kathy, 109

Jacobs, Cindy, 114, 132, 138, 192

James. Brends 105, 192

James Catherine, 138, 140.225

James. Deborah, 225

James, Linda, 180

Jamison, James, 111, 122, 124, 205

janten, Dawn, 102, 124 189. 192

Jarvis, Charlene, 69,109,180

Jarvis, David, 54, 55, 225

Jeffords, John

Jerisk, Francine 205

Jenkins. Susan, 127, 192

Johnson, Brad, 97, 188, 192

Johnson, Brian, 180

Johoson, Dovid, 192

Johoson, Doug, 110, 192

Johnson Karen, 119, 141, 180

Johnson, Marilyn, 192

Johnson, Mark, 180

Johnson, Martha, 192

Johnson, Sandra, 225

Johnson, Virginia, 118, 135, 180

Johnston. Bryce, 118, 205

Jones, Cindy, 192

Jones, Collette, 180

Jones, Collette, 160

Jones, Dinre, 205 , Kathy, 29, 124, 126, 205

Jones, Mark, 115, 193

Jones, Rebecca, 132, 180

Jones, Pick

Jones, Rick, 133, 174, 180

Jones, Sherri, 205

Jones, William, 180

Joseph, David, 225

Justice, Susan, 25, 180

Jutton, Tawn, 154, 226

Kattentareer, Dan, 205

Kahil Pamela, 125, 127, 175, 180

Kamphausen, Margaret, 42, 193

Karclyi, Robert

Karsian, Kristine, 130, 131. 193

Kautfinan, Kimber, 64, 123, 189, 193

Kautfman. Paul, 226

Kautman, Janice, 43, 105, 139, 205

Kautman, Robert, 142

Kearbey. Kathy

Kearbey, Tamera, 180, 205

Kearsley. Debbie, 59, 84. 135. 180

Keener, Joseph. 226

Kehus. Betty. 193

Keller, Chery! 193

Keller, Steve, 54, 123, 180

Kelley, Craries

Kelso, Denise, 102, 141,200, 205

Kennedy, Sherry, 180

Kerrigan, Debbie. 226. 245

Kerrigan, Kenneth, 226

Kerrigan, Susan. 193

Keys, Debra, 138, 193

King, Joel, 180

King, Matthew

King, Robert, 109, 134, 205

Kinhade, Russell, 226

Kinkle, Rochelic, 226

Kirby, Hope 181

Kurby, Kelvin

Kirby, Mark, 122, 205

Kirk Desiree, 42, 103, 137, 139, 205

Kirkbride, Kathy

Kiser, Ann, 133, 193

Kisner. David. 122, 152, 227

Kisner. Wendy, 114, 122, 226

Kitchen, Debbic, 151

Kitchen, Julie, 119, 181

Klamm Joyce. 193

Klvez Georze, 193

Knapp, Mark

Knapp. Mary. 193, 205

Knicely, Susan, 127, 139, 18 !

Knight, Tracy. 25, 122, 181

Koch, Anna 193

Kohns. Jeff, 24, 205

Kohns. Tim, 181

Kolk Dave, 193

Kolliar, James

Koams, Pavla, 17, 193

Krause, Gladys, 193

Kreamer, Rebekah

Kreidler, Sheryl, 181

Krewson, Kathy, 69, 181

Krewson, Richard. 193

Kuhn, Catherine, 19?

Kuhn, John, 193

Kuhn, Rebeces, 45, 58, 59, 126, 227, 243

Kuhn, Takae, 18

Kulp, Pattie, 18 !

Kulp, Susan, 59,84,135, 193

Kuns, Craig, 193

Kunz, Charlene, 105, 18!

Kuntzetman, Susan, 124, 205

Kuschel. Linda, 102, 124, 133, 193

LaHaye. Lori, 24, 105, 139, 194

Lambert, Jayne, 227

Lambert, Keith, 227

Lamm. Joe. 106

Lancaster. Carol, 60, 84, 227

Lane. Betsy

Langley. Margaret. 18!

Lanphier. Ball. $104.120,123.205$

Lantz Jerry, 64, 123, 135, 205

Lapp Karen, $127,141,144 \quad 194$

Larson. Davic. 181

Larson Ron 18

Larson, Ron, 181

Lawhead, David $22,39,81,127,181$

Lawrence Detora. 194

Laxton, Fredrick. 205

Leach, Mark. 54. 143. 181

Lechner. Parn 18

Lee. Arenda 227

Lee Kevin

Leeke to 102, 106, 123, 205

Leightenheimet, James, 43, 124, 139, 194 Lenington, John 56,87

Leston, Philis, 227

Levin, Sheri, 103, 104, 123. 125, 126, 194

Lewis, David. 18

Lewis, Donald, 133. 205

Lewis. Steven, 94, 125, 187

Lightner, Nancy, 114, 139,194

Limbanigh, Jack, 181,194 
Messenger. David, 103, 122, 206 Metager, Kafen, 229

Michalski, Patricia, 114, 195

Michel Roger, 94, 102, 195

Mick, William, 123, 183

Mignard, Mike, 52, 54, 110, 111, 135

Miler, Brian, 108, 129, 137, 230

Miller, Corene, 183

Miller, Craig, 30, 45, 121, 131, 145, 206, 209

Miller, Cynthia, 103, 111, 120, 137, 206

Miller, Elizabeth, 182

Miller, Philip, 29, 31, 123, 126, 206, 209

Miller, Darlene, $115,138,206$

Miler, Stephen, 102, 142, 230

Milss, Paula, 183

Miner, Abert, 206

Miner, Jane, 206

Minnich, TyAnn

Mishier, Joyce, 11, 113,126, 183

Mitchell. Doug 195

Mitchell, George. 54, 55, 11

Nohler. Deimar 206

Mohier, John. 12, 28, 125, 126, 138, 206

Mohier, Kim, 183

Mohler. Thomas, 230

Noline, Larry, 183

Monday. Pam, 230

Monroe, Charles. 208, 230

Nonroe, Linda, 183

Monts, Diane, 230

Moore, Diane, 59, 116, 195

Moore, Jane, 183

Noore, Martina, 114, 183

Moore, Rayanne, 132, 206

Noore, Sandra, 111, 136, 183

Noore, Tim, 23, 125

Morgan, Alan, 112, 122, 142, 143, 206

Morgan, Carol, 39, 59, 183

Morgan, Diane, 119, 141, 183

Morris, Barbara, 183

Morris, Cheryl. 206

Morrow, Joyce, 206

Merter, Scott, 183

Mosbacher, Barrett, 107, 124, 195

Moser, Michelle, 62

Moses. Donald. 131, 137, 183

Mounts, Eric. 64.183

Mullet, Deborah, 195

Mulican, Patricia, 59, 118, 135, 183

Mundy, Mary. 183

Murphy. Daniet, 94, 183

Murphy. Scott. 87, 183

Musselman, Stephen

Murzey, Debra

Myers, Debbie

Myers. Rebecca, 120, 230

Myers, Steve. 206

Nace. Jack. 230

Namy, Beth, 32, 110, 183

Namy, Keith, 230

Napier, Carolyn, 90

Neal, Lori, 124, 141, 201, 206

Neally, Brenda, 105 133. 206

Needles, Becky, 183

Neely, James, 195

Nelson, Michael, 38, 112, 127, 23

Nicholl, Gary, 126, 137, 23!

Nichols, James. 206

Nichols, Michael

Noble, Dewey, 206

Norman, Mart, 106, 183

North, Barb

North, Paul, 124, 231, 241

Northcutt, Ruth, 118,195

Nerton. Rachel, 60, 70, 71, 72, 135, 202

Nycum, Bonnie

Ochert Judith, 195

O'Donnell, David. 183

Otiver, Leslie, 195

Olson, Cherlette, 118, 133, 137, 139, 212

231

Olsen, Laura 183

O Neal. Stephen. 54, 183

OQuirn. Cindy. 195

OQuim, Mke, 79, 81, 113, 195

Ormsbee. David, $45,102,104,231$

Ortin, Sandra, 183

Ouellette. Debbie

Ouellette. Harvey. 195

Ouetiette, Julie 206

Overholser, Jenny

Owan, Cynthia, 114, 195

Painter, Allisen

Paimer, Laura, 70, 87, 90, 91, 135, 231
Paradiso, Susan, 138, 231

Parker, Chice, 113, 183

Parker, Evelyn, 133, 195

Parkef, Linda, 207

Parkinson. Anna, 183

Parlier. Timethy, 207

Partridge, Donna, 195

Parvin. Donald. 102, 188, 195

Parvin Susan, 208

Paschall, Tom, 106, 124, 134, 136, 174, 183

Pascucci, Cerinne, 183

Pasma, Andy, 231

Passmere, Burdette, 207

Patterson, Mark, 207

Patterson, Wendy, 141. 195

Patton, Allen, 231

Patton, Lynda, 195

Payne, Elien, 183

Payne, Joel, 87

Payne. Kathy, 107, 195

Payne, Karen, 106, 134, 136, 137, 196

Payne. Keliy, 103, 196

Payme. Nancy, 107, 138, 207

Pearce, Sally, 232

Peer, James, 208

Perneli. Sardra 183

Penquite, Landa, 62, 63, 90, 91, 124, 196

Perry. James 207

Perry. Paul, 184

Perry, Roxanne, 232

Perry, Sue 232

Peters, Mark, $30,86,87,115,196$

Peterson, Judy, 196

Peterson, Mark 232

Peterson, 196

Petry, Stephen, 196

Philips. Amna, 82, 84, 135

Phillips. Claire, 128, 131, 13 ?

Phillips, Glendolyn, 196

Phillips James

Phillips, Aon, 31, 39, 126, 139, 184

Piazza, Steven, 120, 184

Pierce, Mark, 196

Pippin, Denald, 74, 77, 196

Pippin, Jeanne, 128, 232, 242

Poline, Steve, $137,232,243$

Poole, Daniel, 111. 196

Pocle, Jacque, 94

Pope, Randal, 109, 142, 184

Potter, Debbie

Potter, Debbie
Potter, John, 44, 64, 135, 201, 207. 209

Prentice, Beth, 107, 140. 207

Pressau, Marty, 118, 207

Price. David 106, 127, 133, 174, 184

Price, Karen $100,101,207$

Price, Larry

Priola, Jofilen, 62, 63

Prokoo. Carl, 103, 126, 184

Prugh lane. 115, 207

Pruitt. Jody, 196

Putman, 138207

Putnam, Katherine. 138. 184

Quinn, Donald, 207

Raabe, Roon, $62,118,135,184$

Raber, Jon, 28, 30, 31, 125, 126, 139. 232

Radcift, Charles 196

Rae, Michael, 103, 23 ?

Ramsey, Lisa, 127, 184

Pandall, Lee, 94, 100, 101, 196

Ransem, Deborah, 25, 232

Rapinchuk, Debbie, 100,101, 196

Rayburn, Marilyn, 233

Redinger, Elen, 207

Pedmond, Terry. 105, 184

Peed, Debora, 196

Peeder, Deb, 184

Aeep, Daniel, 64, 102, 184

Peep, Jeff, $64,65,135,233$

Pees, Christy, 233

Rehn, Nathan, 118, 133, 134, 137, 189, 196

Peid, Debbie. 128, 196

Reinhoidt, Marilynn, 126, 184

Reitnaver, Nancy, 122, 233

Reno. Wiliam, 233

Repd, Darlene, 196

Peu, Janice, 138, 196

Reynolds. Patricia, 126, 127, 207

Peynolds, Sandy, 106, 184

Phines. Judy, 207

Phines. Loreiei, 25, 207

Pice. Keith, 16, $17,96,97,111,196$

Pichards, Janice 233

Pichardson, Douglas, 106, 107, 122, 136

137. 138,196
Richardson, Terry, 207

Richer, Fred, 66, 123, 184

Rickard, Don, 66, 67, 78, 81, 184

Piddle, Dave, $96,97,112,135,233$

Riegle, Susan, 60, 83, 84, 184

Riggs, Brian, 110, 123, 196

Risser, Kevin, 184

Risser, Laur3, 70, 233

Riter, Ju, 17, 29, 31, 103, 122, 127, 207

Roberts, Lloyd, 31, 125, 127, 207

Robery, Deborah, 141, 23

Robinsen, Sharlene, 184

Rock, David, 153

Rodak, Ron, 196

Rogers, Dave. 87

Rogers, Phonda, 140, 234

Rohde, Joseph, 118, 20 ?

Rohm, Cathy, 234

Rollman, Irvin, 197

Roloff, Bill, 234

Romango. Michelle, 184

Romein, Marcia. 207

Ronik, Timothy, 184

Rose. Richele, 106184

Rosenau. Johin. 105, 184

Ross, Amy, 45, 88, 90, 91, 121, 124, 131.

145,234

Rossi, David, 234

Roth Barbara. 59. 133. 207

Roth. Sancra. 101. 141.197

Rothnaar, Debbie. 14, 125, 184

Roush, Betty, 116, 207

Rowe. Danny 108, 122, 184

Rowe, Wesiey, 79, 81, 111, 135,234

Rowland Jonathan, 184

Rowland, Timothy, 136, 234

Ruiz, Thomas, 77, 136, 137, 207

Runge, Sandra, 118, 184

Rupo, Becky, $110,120,189,197$

Ryalls, Catherine, 108

Ryan, Mine

Ryberg. Mary. 184

Sabades. Bruce. 107, 137

Sagraves, Joyce

Sad, Phillip, 87, 184

Samuelson, Cheryl, 90, 184

Sands, Dorene, 60, 61, 70, 207

Sonten. Julie, 69, 184

Santerre, Donna, 234

Sarver, Clyde, 142, 197

Schaechterle, Dale, 184

Schieber, Debbie, 106, 114, 197

Schierwazen, Elizabeth, 234

Schultz, feth, 184

Schwerike. Mark, 64, 67, 114, 207

Scozzins, Sheryd, 197

Scott. Dean, 137, 207

Scott, Perzy. 235

Scott, Rachel, $90,100,106,184$

Seawell, Lawrence, 184

Seefried. Kimberly, 62,184

Segerstrom Pryan, 111. 136

Seldon Debbie 59, 84, 123, 197

Selt, Dan, 235

Seriseney, David

Severs, Bruce, 23.186

Seymour, Karen, $103,123,127,207$

Shatter, Susan, 184

Sharks. Phillp 184

Sharp Lela 108.185

Shaw, Vartin, $120,124,133,212,235$

Shaw, Sharon, 207

Shedden, Rachael, 197

Sheldon Fionald 207

Short Oave, 185

Shubert. Timothy, 19

Shugars, Melissa, 213, 235. 240

Shumaker, Dawn, 137, 138, 140, 23

Shuneson, Craig, 77, 185

Simmons, Kim, 207

Simpson, Andrew, 111, 113

Simpson, Beverly, 184

Sirks, Colleen, 122, 197

Sirks, Colette 184

Slusher, Patty. 197

Slusher, Pete, $97,112,124,135,235$

Slyby. David, 208

Smith, Catherine, 141, 235

Smith, Dawn, 185

Smith, Fotwards, 118, 134, 139, 185

Smith George. 125, 127

Smith, Gwendelyn, 31, 185

Smith, Jack, 207

Smith, Joel, 118, 126,185

Smith, Kim, 68, 197

Smith, Meianie. 124, 207

Smith. Randall, 20 ?

Smith, Richard

Smith, Rick, 185

Smith, Roger

Smith, Ronda 103, 122, 207

Smith, Susan, 122,207 
Thompson. Steve, 159

Throckmorton. Debbie, 208

Throckmorton. Warren, 129, 133, 201, 208

Tillman. Nancy, 100, 101. 198

Tillson, Darlene, 90, 110, 134, 198

Tindal, Barry. 198

Tipton, Anna, 208

Titus, Stephen, 125. 208

Toeicka, Dorothy. 237

Tompkins. Mike, 186

Toro, Deborah, 208

Totman, Valerie. 60,237

Towle, Stacy, 103, 198

Traphagen, Janis, $107,126,129,139,186$

Treese. Dana, 59,198

Treese. David. 56, 87, 198

Treese. David, $56,87,198$
Trittipoe, Rebekah, 58. 59. R9, 90, 91. 238

Turek. Ruthanna. 186

Turner. Kathieen, 62, 63.198

Turner, Patricia, 18 7

Twige, Larry, 238

Tyler, Debbie, 103, 187

Uibrich, Beverly, 187

Umphiett. Jon, 187

Unroe, Nancy, 33, 126, 198

Utiey. Sharalee, 198

Uzel, Rodney, 159, 238

Vail, Marienne, 198

Valentine, David, 199

Van der Hoeven, Pegzy, 102, 209

Van Loan, Deb, 187

Van Ryn, Debbie, 115, 145, 199

Varnols, Teresa, 140, 187

Vater, Pauls, 187

Veldt, Joel, 122, 136, 137,208

Vermon, Diane, 136, 141, 143,199

Vesiko, Bonnio 120,121, 133,187

Viall, Bruce, 187

Vincent, Matt, 125, 128, 138, 199

Vinson, Barbara, 84, 135, 187

Vogel, Julie, 208

Volimer, Alvin, 187

Vonado, Susan, 187

Wagner, Dave

Wagner, Glenna, 238

Wagner, Joyce, 208

Wagner, Randy, 125, 208

Wagner, Ruth, 208

Wagner, Sandra, 106, 187

Wagner, Tina, 208

Wainwright, Karen, 138, 199

Waiters, Kevin, 64, 65, 135

Waites. Kim. 103, 199

Waldo. Pam, 238

Walker, Christopher, 17, 87, 187

Waker, Kay, 208

Walloce, Mary, 187

Walter, Paul 94,187

Ward, Jearl, 118, 129, 142, 208

Ward. Virginia. 127, 128. 199

Warix, Jeft, 200

Warren, Mark, 74, 76, 77, 78, 81, 130, 208

Washburn, Perry. 238

Waterman, Daryt, 125, 187

Watts, Cherie, 22, 45, 238

Watson, Paut, 208

Weaver, Carey, 94, 112, 127

Webb, Ken, 118,187

Webber, Allen, 125, 127, 201, 208

Weboer, Bonny, 125, 127, 138, 187

Wehman, Ruth, 187

Wehrly, Cindy

Weller, Barry, 115, 238

Wellinghott, Deborah, 104, 187

Wells, Wendy. 199

Weiton Gary, 106

Weiton, Gary, 106
West, Daie, 75, 76, 77,208

West, Lydia, 16, 29, 30, 31, 32, 33, 45, 122.

West, Lydia, $16,29,30,31,32,3$
$129,139,238,243,245,247$

Westfall, Donald, 187

Westplate, Joanne, 208

Wetzel, Danette, 68, 69, 127, 199

Wetzet Ronald, 118, $132,133,142,187$

Wheeler, Craig, 187

Wheeier, Joyce, 44, 126, 133, 239

Whitacre, David, 187

Whitaker, Brian, 102, 132, 142, 239

Whitolaw, Faith, 239

Whitestine Claudia, 113, 127,208

Whiting. Thomas, 187

Wickham David, 37,187

Wickham. Gregory. 118. 134. 208

Wickman Daniel 127.239

Wicks Corette, 102, 104,18 ?
Wievin, Dorothy, 109, 119, 138, 199

Wicox, Randy, 118. 187

Widermuth, Karen, 208

Wikinson, Susan

Wilan. Jacqueline

Willetts, Jan, 129.239
Willetts, Joyce, 199

Wilietts, Joyce, 199

Waliams, Evelyn, 116, 117, 122, 140, 187

Waliams. John, 199

Williams. Lynn, 199

Williams. Robin, 138

Waliams Ruth

Wiliams. Thomas, 135, 239

Wiliams, Kathy. 103. 106. 199

Wais, David. 54, 187

Wilsey. Steven, 44. 208

Wison, Aian, 106

Wisson, Dare, 187

Wison, Scott, 102, 208

Wison, Tonia, 187

Wind, Androw, 56, 187

Wind, Connie

Winward, Robert, 239

Wisnoski, Lisa, 11, 141, 187

Wittinger, Bradiey, 87,199

Wolf, Richard

Woif, Raphael, 118, 136, 208

Woodail, David 108, 109, 208

Woodall, Judy, 187

Woodring. Valerie, 208

Woods, Kerneth, 127, 139, 199

Wozniak, Michele, 199

Wright. Cynthio, 208

Wright, Edwin, 239

Wright. Jenny, 105, 187

Wright, Leesa, 187

Wright, Tammy, 187

Wuebben. Reree, 208

Wyse. Eric, 33, 126, 199

Yater, Loona, 107, 136, 208

Yater, Thomas, 56, 87, 110, 120, 134, 199

Yerty, Brends

Yhap, Joy, 208

Yockey, Nancy, 187

Yoder, Alvin

Yoder, Janice. 199

Yoder, Russell, 121, 137, 239. 243

Yoder, Vernon, 187

Young, Amy, 68, 69, 107, 124, 141, 199

Young. Rhonda. 69, 128, 240

Young. Richard, 240

Young. Robert

Youngman, Gary

Zachary. Janice, 100, 101, 112, 139, 208

Zaller, Debby, 240

Zelonis, Carl, 120, 212, 240, 246

Ziemer, Bechy, 70, 240

Zink, Suzan, 39, 131, 139, 141, 208

Abbas, Robert, 169

Aser, Ruth, 15 ?

Anderson, Lye. 126, 164

Armstrong. Mead

Baker, J. Wesley. 166

Baker, Rebecca, 25, 139, 166

Baldwin. Martha. 158

Baldwin, Richard. 162

Batard, Stanley, 169

Barth, Charles, 149

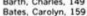

Bates, Carclyn, 159

Baumann, Donaid, 170

Bediord. Rudy

Beikert, Grace

Beikert, Robert, 150

Benefiel, Maxine, 158

Benson, Linda. 151

Bergen, Audrey. 158

Bergen, Harman, 167

Berkenstock. Nova

Bertschinger. Betty. 155

Biddle, Jim. 22, 163

Biddle, Sharon, 22.166

Boston, David 153

Bowersox, Bernice, 168

Braithwaite. Edwin, 170

Bresson, Franos, 149

Brock, tynn, 150

Brock, Wiliam, 149

Brown, Stephen, 150

Bruce, Connie, 158

Burns, Jana

Burrichter. Margaret, 158

Coll, Galen, 149
Callan, Donald, 123, 165

Cartson, Paul, 163

Carr Hukh

Carraher, James, 149

Case, Nancy, 167

Chambers, James. 159

Clark, Martin. 155

Clark, Russ, 87

Cline, Jack, 149

Cole, Harry, 158

Conklin, Wilma, 150

Corriell, Ronald. 163

Dailey, April 156

Davis. Cynthia, 159

Davis, Gienn

Deichert. Steve, 159

Diehi, Pameia, 89, 90, 165

Dilon, Dallas. 159

Diton, Debbie, 159

Dilion, Ger

Dillon, Robert, 159

Dinnen, Ter

Divan, Linda, 156

Dixon, Pat. 132, 167

Dixon, Paul, 46, 244

Dodson, Irma, 163

Draxder, Jehn, 149

Dunn, Marths, 163.139

Durham, Richard, 160

Dyke, Arthur 149

Edlund. Cathy, 159

Elington, Charles, 164

Elmore, Austin, 171

Elmore, Marabeth, 158

Engelmann, George, 149

Evans. Kenneth

Fillinger, Pegzy, 158

Filson, Earl, 118

Filson, Lyle, 159

Filson, Mary, 156

Fisher, Jean, 160

Fissel, Nancy, 159

Foulis, Glenda, 156

Frank, Dwayne, 163

Frye. Bert, 171

Gale, Ralph

Cathany, Paul, 153

Gidley, Debbie, 150

Gidley, Irene, 157

Gallette, Lois, 156

Green, Harold, 104, 120, 152

Green, Markaret. 152

Greenwood. Edward 167

Greenwood. May. 157

Grier. James. 161

Griffeth, Fran, 158

Griffeth, Waiter, 170

Griffiths, Karen, 117,155

Grisham. Albert. 159

Griaham Betty. 158

Grisham. Cynthia, 156

Gromacki, Robert. 160

Grosh, Jody, 38, 167, 247

Grosh, Ronald, 36, 167

Guenin, Roy

Haffey, David, 168

Hall Helen, 163

Halsey, Joseph, 168

Harris, Karen, 158 .

Harvey. Dane, 171

Hawes, Betty, 159

Helmick, Larry, 171

Howell, Kathieen, 16. 104, 152, 154

Hubbard, B, 158

Humn, Caria, 15

Humn, Cala.

Humm, John.
Hurst, C. Ben

Jacoos, Jack, 149

Jettery, Joyce, 158

Jeremiah, James, 46, 48, 49, 148, 149, 244. 245,247

Jeremiah, Maryalyce, 59, 70, 73, 165

Meremiah, Ruby 48

Johnson, Cliftord, 38, 124,149

Kautman, Eileen, 159

Kautman, Phi, 159

Kearnoy, June, 60, 84, 165

Kern, Roy, 15!

Kiltan, Larry, 171

King. Elwin, 56, 87, 165

King. Toinetre, 156

Kirchner, Virginia, 154

Kool Dean. 164

Kriel, Constance. 158

Lawior, George, 160

Maddox, Miriam. 166

Matson, David, 127, 164

Matson, Rebecca

McClure, Phaip, 164

McDonaid. Bruce, 152

McDonald, Cleveland

McGillinray. John, 54, 87, 165

McGoldrick, James. 168

Mclatosh, Barbara. 156

Vcintosh, Michael, 159 

